


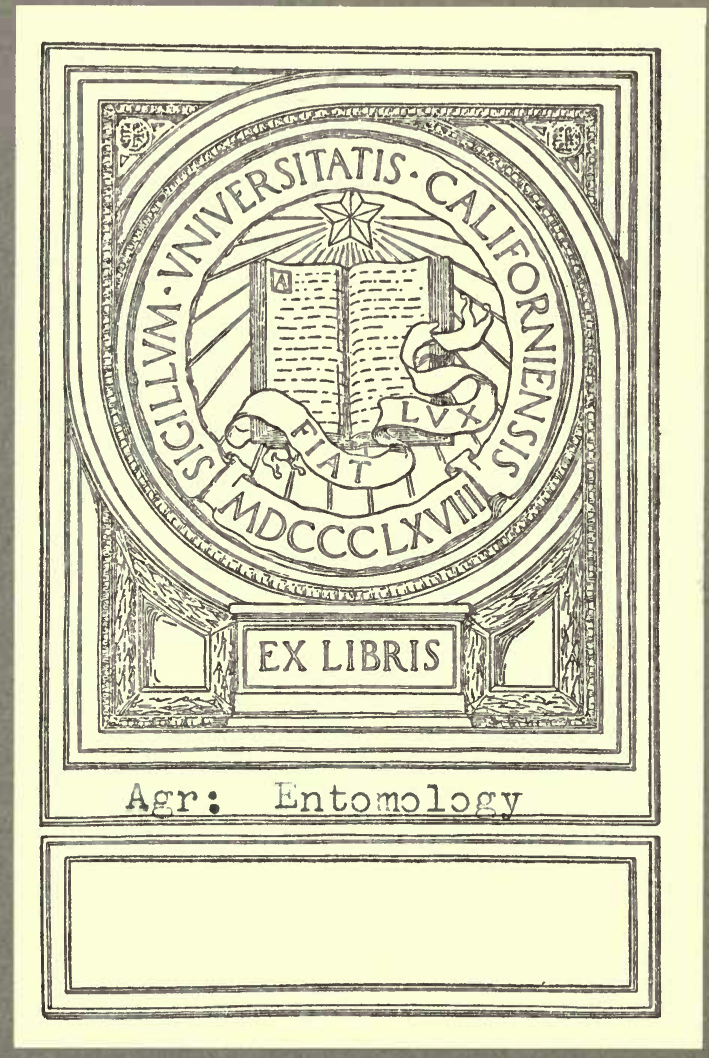




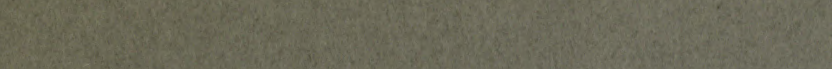

1.7. a.

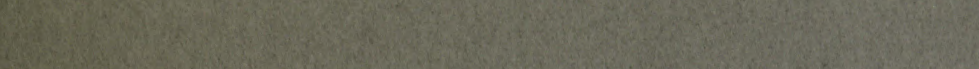

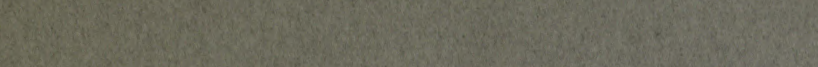

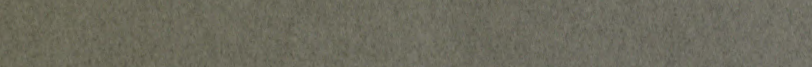

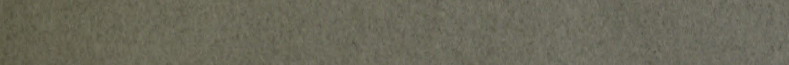

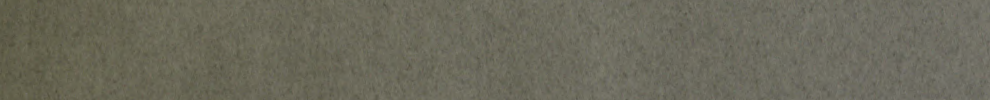

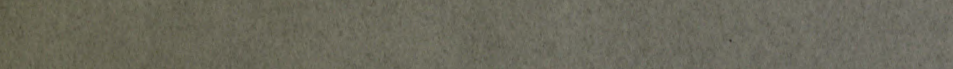
8. The 1.5.5.

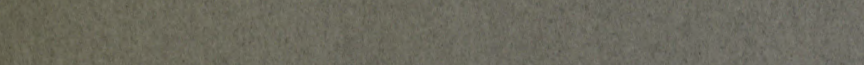
15. W. W. S.5.5.

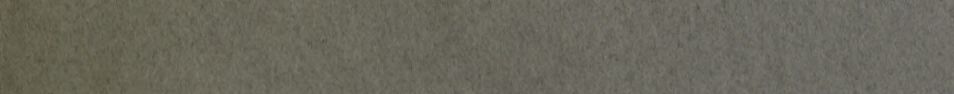

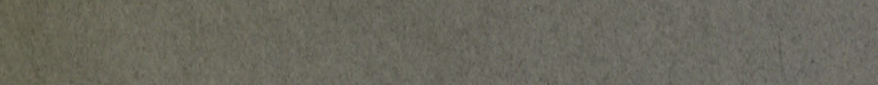

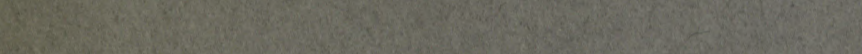

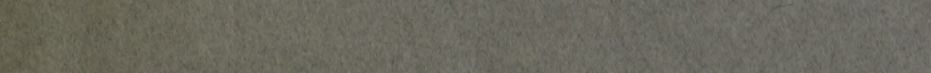
2.5.

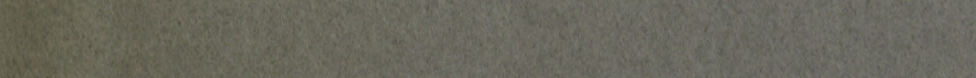

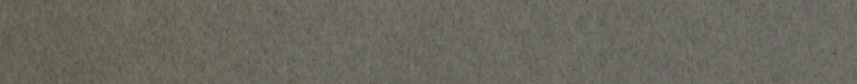

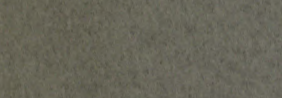

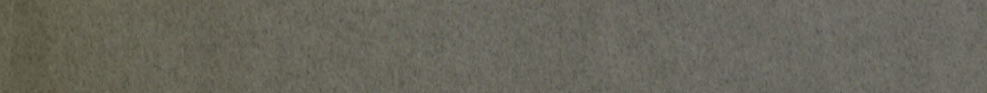

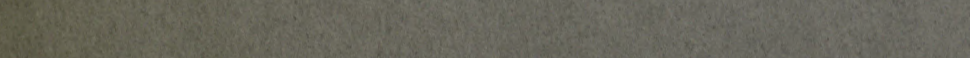
19. 




$$
a_{g-\text { Etandergy }}
$$


Note on the Genus Brahmæa of Walker.

By Artuur G. Butrir, F.L.S., F.Z.S., \&c.

The first figure of a species in this genus is that by Petiver (Gazoph. tab. 18. fig. 3), a perfectly recognizable illustration of a species recorded as coming from the island of Chusan, and, as I have noted (P. Z. S. 1866, p. 458), identical with B. lunulata and unclulata of Bremer, a good figure of which is given in Ménétriés's Catalogue of the Lepidoptera in the St.-Petersburg Museum (pt. iii. pl. 15. fig. 5).

The first description of an Oriental species is that of $B$. certhic given by Fabricius in the 'Entomologia Systematica,' iii. 1, p. 412. n. 16 (1797); and as this description does not seem to have been looked at by living Lepidopterists, at any rate in recent years, it will perhaps astonish them not a little if I quote it verbatim :-

"Certhia. 16. B. alis patulis rotundatis fuscis apice cinereo albo fuscoque undatis.

"Petir. Gazoph. tab. 18. fig. 3.

"Habitat in Chusan. Mus. Brit.

"Magna. Corpus fuscum collari abdominisque lateribus cinereis. Alæ omnes concolores, basi fuscæ, apice cinereæ, albo fuscoque undatæ."

Therefore there cannot be a question that the B. lunulata (and undulata) of Bremer is the typical B. certhice of Fabricius. The $B$. certhia of Walker, figured by myself (P. Z. S. 1866, p. 119, fig. 1), may consequently be named $B$. conchifera, on account of the beautifully shaded shell-like submarginal spots upon the wings.

Another point in the synonymy of this genus has also been cleared up through the transfer of the types of Lepidoptera in the India Museum. Among these we receired a Nepal species bearing the type-labels of B. Wallichii, Gray, and B. spectabilis, Hope, and agreeing perfectly with both descriptions and the figure. The specimen is from the collection of General Hardwicke, as stated by Hope, and differs strikingly, both in coloration and pattern, on both surfaces from the better-known $B$. conchifera of Darjeeling and Silhet.

The true B. certhic of Fabricius, which 83 years ago was quoted as in the British Museum, is now also not to be found.

Two examples of B. Wallichii in Mr. Druce's collection agree in all important characters with the type. 

Description of a new Species of the Homopterous Genus Aphæna from Sumatra. By ArTHUR G. BUtLer, F.L.S., F.Z.S., \&c.

THE species which I here describe was obtained last year by purchase, and it struck me at once as a very beautiful and new Homopteron allied to Aphoena submaculata; but upon showing it to my friend Mr. W. L. Distant, I found that he was inclined to regard it as a very fine and highly coloured variety of that species, though without careful comparison of the structural details of the two insects he was not prepared to declare absolutely that they were not distinct. This, after a minute examination of our specimens, I am fully convinced to be the case, and therefore I do not hesitate to describe the species.

\section{Aphoena chioncema, sp. $\mathrm{n}$.}

General form of $A$. submaculata, but the tegmina relatively broader across the middle, owing to the greater arch of the costal margin* ; the outer margin is also very decidedly longer, forming an oblique straight edge instead of an arch continuous with that of the apical portion; the apex, therefore, is more prominent than in A. submaculata. The thorax,

- This I hare proved by careful measurement, the difference in width between the middle and the widest part in these wings being exactly 2 millim. both in the larger and the smaller insect: to an artistic eye the different outline is most marked. 
though naturally larger altogether, is comparatively slightly shorter; and the spinose dorsal processes in the centre of the hind margins of the meso- and metanotum are distinctly more prominent; the posterior edge of the pronotum is more distinctly carinate, and the surface much more irregular; the front margin of the head is comparatively much narrower, making the head altogether less quadrate in form; the reflexed frontal horn is considerably longer, being carried backwards the whole length of the head over the pronotum, whereas in A. submaculata it is of only two thirds this length; the upper surface of the horn is narrower throughout, and therefore more sharply sulcated down the centre; the frons is almost identical in form and sculpture; spines on the posterior tibiæ less acute.

Tegmina above blood-red, mottled all over with snow-white spots, most of which are confluent beyond the middle; the costal and external borders regularly spotted, the former with white and the latter with slaty-black spots: wings intense black, sparsely spotted with white, butt the spots much smaller than in $A$. submaculata; the apical border washed with chestnut-red; veins at base scarlet; the abdominal and anal borders whity brown, interrupted by the white spots: head and pronotum scarlet, the latter with black lateral anterior margins and a black spot on each side; mesonotum black, with a large irregular central scarlet patch; metanotum black, outlined in scarlet; abdomen cadmium-yellow, almost entirely covered by the ordinary white waxy secretion common to the group; tegmina below brilliant carmine-red, the basal two thirds streaked transversely with grey; a few white-centred glaucous-grey rounded spots scattered irregularly over the external third; costal border crossed by black spots and dashes; external border with a marginal series of small black spots. Wings below much as above, but the nervures beyond the middle relieved in greyish white, and the white spots congregated on the apical instead of the abdominal balf, the borders also greyish, veins at base scarlet, as above: body below scarlet, margins of metasternum stramineous; middle and posterior coxæ clouded with black. Exp. tegm. 89 millim.; corp. long. 26 ; noti lat. 9 ; long. cum capite $12 \frac{1}{2}$; abdom. long. $13 \frac{1}{2}$.

Sumatra (Ch. Curtis). 'Type B.M. 
On the Priority of Euploea Castelnaui of Felder over Euplœa phœbus. By Arthur G. Butler, F.L.S., F.Z.S., \&c.

In the first part of his 'Rhopalocera Malayana,' p. 24, Mr. Distant gives priority to $E$. Castelnaui; he remarks as follows :- "As Mr. Butler has himself admitted the identity of his $E$. phoebus and $E$. Castelnaui, Feld., of which there can be no doubt, it becomes necessary to use the earlier and Feldcrian name to this insect, though Butler still retains his own designation." Here Mr. Distant inserts a footnote to this effect:- "This author has (Trans. Ent. Soc. ser. 3, vol. v. p. 471) argued that Felder's work was antedated."

It is an exceedingly uufortunate fact that, although I have been assured positively on two difforent occasions (by men who knew the truth) that Felder's second volume was antedated, I have never been able to use their declarations as positive evidence-the first witness (an Austrian, though not an entomologist) having stated facts of which he did not know the importance, unaware that in so doing he was giving evidence against a personal friend; to give the name of this innocent informer would have been inexcusable.

The second case is a harder one, since we have here to do with a well-known German lepidopterist, who, though also a friend of the Felders, ought to have set aside his personal feelings in the interest of truth and justice. This gentleman showed me the actual date of publication written by himself upon the cover of the part when received, and he assured me that it had been forwarded to him (according to instructions given to the publisher) as soon as it was ready.

I have elsewhere pointed out that Hewitson gave instructions* that the part should bo sent to him as soon as ready, but that he also never received it until the end of January 1867 ; nay, he was informed in the early part of that month that it was not ready. The explanation offered by the Felders was, I believe, that the coloured copies were not ready, but that the work could be obtained uncoloured.

* I see, however, that I did not mention his name, although he never asked me not to do so. 
It is a singular fact that early in 1867 , when I was commencing my 'Catalogue of Satyrinæ in the British Museum,' I had seen neither the second nor the third parts of the 'Reise der Novara ;' and not knowing in which volume the Satyrinæ would be published, I wrute to the Felders informing them that unless I could see proofs or advance sheets it would be impossible for me to include their species in my Catalogue; and that, in answer to this intimation, they forwarded to me proof-sheets with plates on thin paper of the second and third parts. One would have supposed, had the second part been ready in an uncoloured condition, that the Felders would have wished to prove the fact by sending it in its bound form with thick plates.

Now my reason for again calling attention to this vexed question is from a feeling that Mr. Distant (to whom I had asserted my knowledge of the antedating of Felder's second part upon authority, to which, nerertheless, I was unwilling to refer) has hardly done me justice in allowing it to be supposed that I retained my own name, knowing that Felder's had priority. As for what he says about my quoting Felder's date subsequently, he must be aware that in so doing I had taken the date from the titlepage, either failing for the time being to recall the fact of its inaccuracy, or inserting it between inverted commas to show my disbelief in it.

Mr. Distant is too old a friend not to be sure that I should at once prefer the name proved to be of earlier date whether it displaced my own or not: to retain one's own name for a species when priority has been proved for that of another author, is a childish form of egotism of which, as he well knows, I was never guilty. 
[From the Annals and Magazine of Natural History for January 188.5.]

Note respecting Butterflies confounded under the name of Delias belladonna of Fabricius. By Arthur G. Butuer.

For some years past it has been maintained by most lepidopterists that Papilio belladonna of Fabricius, figured by Donovan in the 'Naturalist's Repository,' is the female of Detias Horsfieldii of Gray's 'Insects of Nepal ;' on the other hand, I have always insisted that, however bad Donovan's figure might be, it represented a brown and not a black species, a male and not a female, and certainly a species in which the whole abdominal border of the secondaries was yellowish white, not partly white and partly yellow.

Amongst the Lepidoptera of the late Mr. Charles Horne, collected in the North-west Provinces of India, I found a single specimen of a Delias which, after comparison with Donovan's figure, I am satisfied represents the true $D$. belladonna; it is a brown, not a black insect, it is a male, not a female, and the abdominal border of the secondaries is wholly creamy 
white; the yellow spot at anal angle is also perfectly separate from the yellow commencement of the discal macular band, as in the figure by Donovan; the shape and markings of the primaries are quite as in that figure, and therefore quite dissimilar from $D$. Horsfieldii $\delta$.

I think therefore that we may conclude that Delias belladonna is a species confined to the North-west Provinces, that D. Horsfieldii is confined to Nepal, and that other forms allied to these may yet be expected to turn up. The two following have been confounded with $D$. Horsfieldii:-

\section{Delias Hearseyi, sp. n.}

o. Nearly allied to the Nepalese D. Horsfieldii, slightly smaller; the yellow patch at base of secondaries duller and of a more orange colour; the yellow patch on abdominal area only represented by a dull yellowish nebula at the extremity of the white area, which is restricted owing to the anal angle being broadly black-bordered; the yellow spot near anal angle represented by a few white scales, whereas in $D$. Horsfieldii it is always present as a squamose yellow spot subconfluent with the abdominal patch : on the underside all the yellow spots are of a dull chrome-yellow, not bright gamboge, as in D. Horsfieldii; they are also rounded and narrower than in that species, so that they are in consequence smaller and further apart. Expanse of wings 79 millim.

Barrackpore (Sir John Hearsey). B.M.

\section{Delias Boylece, sp. n.}

J. Form and size of $D$. Horsfieldii, but in the coloration of the wings much nearer to D. ithiela, the ordinary markings being represented by internervular grey streaks, upon which the subnarginal spots of the primaries and three or four small spots on the disk of all the wings alone show white; base of secondaries almost brick-red (or dull orange); basal half of abdominal area grey, anal half bright chrome-yellow : below all the spots smaller and much more restricted than in $D$. Horsfieldii; all the yellow spots duller, chrome-yellow. Expanse of wings 84 millim.

Darjiling (Mrs. R. V. Boyle). B.M.

Females in this group seem to be very rare; of the four species here mentioned we only have male examples in the British-Museum series. 
On Doratopteryx of Rogenhofer, a Genus of Moths allied to Himantopterus. By Arthur G. Butler, F.L.S., F.Z.S., \&c.

In my recent description of a new genus-Pedoptila, allied to Himantopterus-I referred (pp. 340 and 342) to a moth from Zanzibar identified many years since by Herr A. Rogenhofer as a Himantopterus, of which, however, no description appeared to have been published.

Herr Rogenhofer has kindly forwarded to me a separate copy of a short paper, published last year in the ' Sitzungsberichten der k. k. zoolog.-botanischen Gesellschaft in Wien' (vol. xxxiii.), in which a description of this moth appears, a new genus, Doratopteryx, being erected for its reception. Although, as I expected, this moth comes nearer to Pedoptila than to Himantopterus, it must stand as a distinct genus between these two.

Doratopteryx, as figured and described by Herr Rogenhofer, differs from Pedoptila as follows :-

\section{Doratopteryx.}

Expanse of wings 17 millim.

Secondaries 17 millim.

Costal and subcostal veins of primaries well separated.

Subcostal branches separate at their origins.

Lower radial and third median well separated at their origins.

Secondaries with two veins.

\section{Pedoptila.}

Expanse of wings 23 millim.

Secondaries $18 \frac{1}{2}$ millim.

Costal and subcostal veins of primaries lying close together.

Subcostal branches emitted from a short footstalk.

Lower radial and third median from the same point.

Secondaries with three veins.

These characters are all easily seen; but others are indicated which have rather a specitic than a generic value, such as the form of the outer margin of the primaries, which in Doratopteryx is slightly sinuous (geschwungen), whereas in Pedoptila it is regularly arched, the slightly shorter inner margin of these wings in the former genus and the different coloration, the type of Doratopteryx having the wings smoky brown, with the basal area golden yellow, whereas Pedoptila is grey, with the base bright russet reddish.

One difference which appears in the two figures is due to an injury to the type of Pedoptila. In Doratopteryx the first subcostal branch forks into two towards the apex; this has, however, clearly been the case with Pedoptila, only the apical portion of both primaries in Mr. Swanzy's specimen is broken 

V. Descriptions and remarks upon five new Noctuid moths from Japan. By Arthur G. Butler, F.L.S., F.Z.S., \&c.

[Read April 7th, 1886.$\rceil$

THe species here described have been recently received from Messrs. Henry Pryer and George Lewis, who collected them personally in Japan.

The difficulty of dealing with aberrant types of familiar genera, owing to the present imperfect definition of many groups of Noctuites, is at once apparent when one has to decide with what genus such a species as the first here described has the highest claim to be associated: that structural characters, as hitherto studied, are insufficient to decide the point, is evident : that characters exist in the present case, which can only be examined by destroying the type-specimen, is probable from the bizarre aspect of the insect; but that this can only be done where there are plenty of specimens to sacrifice, is equally a lamentable fact.

\section{COSMIID正.}

\section{Cosmia curvata, n. s.}

In form and general coloration like Cerastis spadicea, the outer margin of the primaries even more sinuous; in structure almost identical with Orthosia suspecta; * primaries sericeous, purplish slate-coloured with the exception of a submarginal band and the fringe, which are bronze-brown; ordinary lines black, slender, with whitish inner edges; the first subbasal, angular, the second at basal third, oblique and slightly curved, the third just beyond the external third, nearly straight, but with a slight sinus at the point where it is crossed by the first median branch; a fourth indistinct line, limiting the external border, nearly straight from costal

* In neuration I can find no difference between Cosmia, Orthosia, and Cerastis, the primaries having five subcostal branches, all but the first starting from a post-discoidal cellule; the lower radial and second and third median branches being also emitted close together.

TRANS. ENT. SOC. LOND. 1886.-PART 1I. (JUNE). 
margin to third median branch, and thence undulated to inner margin; discoidal spots outlined in white; secondaries sericeous bronze-brown, darker towards the outer margin; fringe whitybrown, traversed by a dark brown line; body brown, the abdomen greyer than the thorax; under surface whity-brown, sericeous, with golden-bronze reflections; primaries, with the exception of the borders, suffused with blackish, and showing darker indications of the third and fourth lines of the upper surface; secondaries crossed by two irregular ill-defined dusky stripes. Expanse of wings, $29 \mathrm{~mm}$.

Fukushima, 28th July, 1881 (G. Lewis); Yokohama (H. Pryer).

Mr. Pryer regards this as a Noctua: in pattern above it is most like a Mesogona, excepting in the border of the primaries, which is like that of an Orthosia: in some respects it is more like a Cerastis than a Cosmia, but the palpi correspond with those of the latter genus: singularly enough it agrees in most respects with the Notodontid genus Beara, but the flatter thorax, more prominent head, longer palpi, and the little cross-veinlet in the primaries forming the post-discoidal cellule, sufficiently distinguish it.

It is strange that neuration should repeat itself, as it does, in widely distinct families ; in the present instance, however, the families are more nearly allied than they sometimes are: neuration, though invaluable as a generic character, cannot be used by itself for the definition of families, for, though it may serve to distinguish some, it will equally unite others which are far more distinct; the little cell above or beyond the discoidal cell, and which has been called "post-discoidal," occurs in many groups of Bombycina, Geometrina, and Noctuina. The number of median branches to the secondaries (the radial when approximated to the third median being called a fourth) is not an invariable character, there being Geometrina, both with three and four so-called " median branches"; whilst Argyria, which appears to be a Drepanulid (as I shall presently attempt to prove), corresponds closely, not only in neuration, but in every other respect, with Somatina, has only the normal Geometrid arrangement of three median branches, and, apart from its great resemblance to Cilix, fully justifies M. Guénée's decision that it belonged to the Geometrina: at the same time it possesses the same number of veins 
as Cilix, has nearly the same arrangement of veins in the primaries, the principal difference consisting in the weak character of the disco-cellular veinlets and, in the secondaries, in the different relative position of the subcostal and median branches, which thus necessitates an alteration in the form of the discoidal cell; such distinctions, though wide enough to separate some families (as in the case of the Enochromiidce among the Geometrina), cannot be admitted to be of sufficient importance to enable one to place Argyria and Cilix in two tribes so wide apart as the Geometrina and Bombycina. On the other hand, the genus Teldenia (proved by breeding to be a true Drepanulid), which is even more Geometriform than Argyria, is intermediate in the character of its wing-veins between the latter and Cilix, whilst the genera Macrocilix and Auzata, formerly associated with Argyria and placed among the Geometrina, are in all their structural characters essentially Drepanulida.

Whether Somatina should also be placed in the latter family or not cannot be decided without breeding it; but, if I am right in locating Argyria there, it would indeed be strange that a genus almost identical with it in the imago condition should belong to so widely distinct a tribe as the Geometrina; nevertheless, it should be borne in mind that structural characters in the imago stages of the Heterocera have not enabled even the best and most painstaking lepidopterist to assign certain genera to their natural positions, the genus Euphanessa, hitherto referred to Bombycina, but now proved to belong to the Geometrina, being a case in point.

That the number of branches to the median vein of the secondaries should be regarded as invariably of the highest importance, will at once be seen to be absurd by anyone who examines the whole of the genera of Zyganida, in which the median branches vary from two to four, and the total number of veins in the secondaries from five to eight.

Therefore, although it is as a rule safe to assume, because of a certain combination of characters in the imago, that a moth belongs to such and such a family, the existence of many aberrant forms, of which the life-history is known, and their natural position 
therefore finally decided, renders any attempt to found a system of classification upon the external structure of the imago alone wholly futile.

\section{HADENID尼.}

\section{Epia claripennis, n. s.}

Allied to E. echii of Europe ; of the same size and with nearly the same pattern; the markings of the primaries are, however, more diffused and consequently less sharply defined, the discoidal spots are grey with white margins, the "orbicular" being oval, oblique, and diverging from the "reniform" spot, which is also less angular than in E. echii; below the "orbicular" spot and upon the interno-median area is an oblong blackish spot (as in Dianthecia capsincola), followed by a small fusiform white spot; below the latter there are no more white markings upon the central belt, the white internal patch which occurs in $E$. echii being absent; the white maculation of the fringe appears also to be wholly absent; the secondaries are white instead of grey, very glossy, and with a faint golden appearance in certain lights, the discal line and outer border are faintly indicated in grey ; the body is sordid whitish, the collar marked on each side with a little arched line; on the under surface the differences are more marked, the primaries being greyish white to beyond the cell, the disc grey, and the outer border pale greyish brown; the disco-cellular lunule is grey; secondaries with the discal lines much less distinct and nearer together than in E.echii; tibiæ and tarsi of front legs greyish in front; not distinctly banded as in the European species. Expanse of wings, $29 \mathrm{~mm}$.

Nikko (H. Pryer).

\section{Dichonia intermissa, n. s.}

Intermediate in some respects between $D$. convergens and $D$. protea; in pattern, both above and below, most like the former, but in the colouring of the primaries approaching the latter; the form of the discoidal spots, the presence of a pale spot below the "orbicular," and the well-defined marginal black dots also correspond with D. protea; the pale scales on the primaries are, however, of a yellowish brown, rather than greenish, tint, and the reniform spot and the dise towards external angle are sprinkled with rust-red scales, somewhat as in $D$. convergens; the lines which bound the central belt are wider apart than in either species, and resemble those of $D$. genista; the secondaries are of a smoky- 
grey tint, gradually darkening from the base to the outer margin; the fringe white, traversed by a black line; under surface smoky grey, the centre of the secondaries whitish, so as to show clearly a small black disco-cellular crescent; other markings obsolete. Expanse of wings, $38 \mathrm{~mm}$.

\section{Japan (H. Pryer).}

In Staudinger's Catalogue I find that the three species above referred to are placed in three separate generaD. convergens in Dichonia, D. protea in Dryobota, D. genistce in Mamestra, but why is not stated; and, after carefully comparing their structure, I fail to see any justification for such a proceeding. M. Guénée placed all three in Hadena, and indicated $H$. w-latinum (= geniste) as type, though the latter was not originally recorded as a member of the genus in Schrank's enumeration of the species: the actual type of Hadena appears to be $H$. cucubali, so far as I have been able to ascertain;* the latter was originally associated by Boisduval with other clearly heterogeneous forms, as representing his genus Dianthcecia, and has subsequently been placed in the latter group.

\section{PLUSIIDÆ.}

\section{Plusia humeralis, n. s.}

Nearly allied to P. chryson; of the same size, form, and general pattern, but the primaries without the golden patch, with the basal area lilacine grey, crossed close to the base by a blackish line, and just beyond this by a tapering blackish band; central area more purplish in tint, with the three lines much darker, and the outermost of the three less strongly undulated; external and apical areas more bronzy, very glossy; secondaries whiter, the line and border better defined; thorax duller in tint, abdomen whiter; under surface cream-coloured instead of ochreous, but in other respects similar. Expanse of wings, $49 \mathrm{~mm}$.

Yezo (H. Pryer).

\section{POLYDESMIDÆ.}

\section{Polydesma vulgaris, n. s.}

Primaries above greyish or cupreous-brown, always pale and more or less sericeous, crossed by numerous ill-defined brown or

* Mr. Kirby has kindly assisted me in looking up the probable type of Hadena, but we have not been able to give sufficient time to the matter to come to any final decision. 
reddish dentate-sinuate stripes, which, however, frequently are wholly lost in the ground colour; two reversed dentate-sinuate darker lines or two stripes slightly paler than the ground colour indicate the limits of the central belt; the orbicular spot is usually ill-defined or absent, but sometimes represented by a whitish spot; the reniform spot is oblique, large, usually whitish, but sometimes ochreous, though always with a white or whitish external edging; the outer line or stripe bounding the central area occasionally has its dentate character defined by a series of black points at the extremities of the denticles; so far all the characters are variable and inconspicuous; the following characters are always better marked-a dark brown almost semicircular basi-costal patch, an unequally quadrate costal patch of the same colour beyond the cell, an irregular more or less dusky outer border bounded internally by a paler stripe, two more or less defined hastate black dashes on the radial interspaces interrupted by the submarginal pale stripe; a marginal series of black crescentic dots with pale inner edges and several dusky or blackish costal dashes; secondaries varying from grey to brown, always sericeous, and with pale golden or bright cupreous reflections, a more or less distinct darker diffused external border; an ill-defined marginal series of blackish dots; fringe whitish; body whity-brown; head, collar and tegulæ dark brown, varying in accordance with the colour of the primaries from greyish to reddish; under surface varying from whitish to bronze-brown; primaries with the central area slightly greyish; all the wings with a blackish disco-cellular spot and two parallel discal lines from costal to inner margins. Expanse of wings, 34-50 mm.

Male and female, Tokei (C. Maries); female, Chekiang (W. B. Pryer) ; male and female, Yokohama (H. Pryer).

This perfectly typical Polydesma is noted by Mr. H. Pryer as a Xylophasia. It is an unusually variable species. 

gune 1806 

XV. Descriptions of 21 new genera and 103 new species of Lepidoptera-Heterocera from the Australian Region. By Arthur G. Butler, F.L.S., F.Z.S., \&c.

[Read June 2nd, 1886.]

THe species described in the present paper were sent to the Museum for identification, with many other previously named species received at the Godeffroy Museum from collectors in Australia, Fiji, \&c. Many of the species, as might have been anticipated, form the types of new genera, but at the same time the appearance of the greater part of them is by no means striking, their colouring being, as a rule, sombre,-of various shades of brown or grey.

All the species here described have been seen by $\mathrm{Mr}$. Meyrick since I wrote the descriptions.

\section{AGARISTIDE. \\ ÆGGOCERA, Latr.}

\section{AEgocera cornigera, $\mathrm{n} . \mathrm{s}$.}

Allied to सE. diversa (Agarista diversa, Walk.), the pattern of the primaries being very similar to that species and to A. ephyra (Herr.-Sch., Aussl. Schm., fig. 27), but of a cupreous-brown colour; base white, divided by the veins, two subcostal spots near the base; an oblique abbreviated fascia immediately below the second subcostal spot, and below it again an elongated spot on internal border; a large quadrate spot crosses the discoidal cell towards its extremity, and below it is an oblique irregular interno-median streak; between the latter and the internal spot previously noted is a small internal dot; beyond the cell is a broad almost 3-shaped fascia, and near the external angle a cuneiform spot; at about apical fourth is a subcostal dot; an abbreviated series of seven dots crosses the disc almost parallel to the outer edge of the 3-shaped fascia, and is followed by a regular submarginal series alternating with a series of quadrate spots on the fringe; all these markings are milk-white; secondaries nearly as in $\mathbb{E}$. bicolor, ochreous, with a dark or cupreous-brown spot across the end of the cell, and

TRANS. ENT. SOC. LOND. 1886.-PART IV. (DEC.) 2 D 
an irregularly sinuated external border of the same colour; fringe white, ochreous at base and spotted with brown, in the male only towards apex, in the female throughout; head and thorax white, the antennæ, a spot on the head, the front of collar, shoulders, two longitudinal stripes on the thorax, and an oblique stripe on the tegulæ brown, a short horny process, flattened and truncated in front projecting from the frons; wings below much as above, but the primaries pale ochreous at the base so as to cover the subbasal spots of the upper surface, the white dots across the disc wanting, palpi white with an oblique lateral black dash and black terminal joint; body below pale ochreous, legs partly brown above, the tarsi barred with white; venter barred with brown. Expanse of wings : male, $29 \mathrm{~mm}$.; female, $37 \mathrm{~mm}$.

Male, Gayndah; female, Peak Downs.

The singular frontal process possessed by this species occurs in a much less highly developed condition in AE. diversa, and therefore I do not think it sufficient of itself to constitute a character of generic value.

\section{LITHOSIID无. Miltochrista, Hübn. \\ 2. Miltochrista simulans, n. s.}

Size and aspect of Nepita conferta (male), excepting in the absence of any dark border to the secondaries; allied to Miltochrista (Barsine) placens from Timor and Ceram; primaries above grey, crossed by five series of ochreous markings, the first across the base semicircular, the second forming an interrupted angulated band across basal third and consistlng of four somewhat oval spots in pairs, the third consisting of three nearly equidistant spots in an angular series across the middle of the wing; the fourth begins with an oval costal spot, below which is a sinuous series of seven small spots only divided by the nervures; the last consists of three unequal angulated spots on outer margin; fringe ochreous; a series of black marginal dots partly impinging upon the fringe; secondaries pale ochreous, slightly deeper towards external border; body ochreous; thorax reddish, spotted with slaty black; under surface more salmon-tinted than above, markings on the primaries obliterated excepting on the borders; legs barred with dull greyish black. Expanse of wings, $32 \mathrm{~mm}$.

Rockhampton.

To any one who neglected to examine the neuration in new species this would appear to be a Nepita 
(Liparida); that Nepita really belongs to the latter family has been proved to me by Mr. F. Moore.

\section{Cyptasta, Walk.}

The following species belongs to a genus which has been referred to the Lithosiida; its structure appears to indicate some affinity to the Micro-Lepidoptera; nevertheless, for the present it may stand where it has been placed.

\section{Cyptasia cristata, $\mathrm{n} . \mathrm{s}$.}

Somewhat nearly allied to $C$. egregiella, but smaller; primaries bronze-brown, flecked with cream-colour and with seven unequal but nearly equidistant spots round the borders of the wing, three costal, the third being a mere narrow oblique dash, one external and three internal; fringe yellow opposite to the white spots; secondaries bright salmon-orange, with a few greyish scales at apex; head sulphur-yellow, crested; antennæ pale bronze-brown, with white basal joint; thorax dark brown, white-spotted behind; abdomen salmon-coloured; under surface salmon-coloured, the primaries greyish, especially towards apex; fringe alternately brown and sulphur-yellow as above. Expanse of wings, $20 \mathrm{~mm}$.

Gayndah.

Until such genera as Themiscyra, Cyptasia, \&c., have been carefully reared, and their actual affinities satisfactorily ascertained, their great resemblance to typical genera of Lithosiida will always tend to raise a doubt as to their actual distinctness from that family; characters offered by the imago alone are, as already shown in the case of the various genera formerly associated under Acronycta, not always reliable; and for this reason (if for no other) all families erected upon the structure of the imago alone should be regarded with disfavour by lepidopterists: there cannot be a question that the Micro-Lepidoptera ought to be distributed among the larger moths, and that the sole reason for which the fathers of Entomology associated them was their usually small size; yet it has been difficult in some cases for the most careful students to decide to their own satisfaction whether they had before them a Deltoid or a Tortrix, a Noctua or a Tinea (these names are applied in their wide signification, of course); even the most confident workers have, after describing a species as a 
Micro-Lepidopteron, come to the conclusion that it should have been placed amongst the Noctuites.

\section{XaNthodule, $\mathrm{n} . \mathrm{g}$.}

Form of Setina (S. ramosa) ; general aspect of Eubaphe, neuration most like Eudule, but that of the primaries quite distinct; costal vein terminating at third fourth of the margin, subcostal five-branched, the first three branches emitted before the end of the cell, fourth and fifth branches emitted from the anterior angle of the cell, forking from a long footstalk; disco-cellulars inangled; upper radial emitted from the anterior angle of the cell immediately below the last subcostal branch; lower radial emitted close to the third median, having the appearance of a fourth median branch; second and third median branches emitted near together but at some distance beyond the first, the latter rumning obliquely almost to the external angle, almost joining the submedian vein at its extremity; discoidal cell of secondaries extending to second-third of wing, the costal margin slightly concave, costal vein running almost to apex, subcostal forked at some distance beyond the cell; disco-cellulars unequally inangled; radial emitted nearer to the median than to the subcostal vein so as to appear like a fourth median branch, it and the second and third median branches being about equidistant ; first median branch a little further apart; body slender, the thorax rounded, the abdomen extending slightly beyond the anal angle of secondaries; antennx thick at base, tapering, serrate-pectinated; palpi wanting.

\section{Xanthodule semiochrea, n. s.}

Primaries pale greyish brown, with an ill-defined paler oblique sinuous transverse central band; secondaries ochreous, with the apex and an ill-defined streak from it along the outer margin dark brown; head white, collar tinted with ochreous, thorax greyish white, abdomen whitish; primaries below smoky brown, with a narrow tapering whitish apical border; secondaries below as above; legs (probably the palpi) and venter ochreous. Expanse of wings, $18 \mathrm{~mm}$.

Peak Downs.

\section{LIPARIDE.}

Chionophasma, n. g.

Aspect of Porthesia, but with more thinly scaled wings, comparatively smaller secondaries, and very different neuration; primaries elongate-ovate, the costal margin only slightly convex, 
apex rounded, outer margin slightly convex, very oblique, continuous with the inner margin, which is also slightly convex; the neuration of all the wings utterly unlike that of any of the whitecoloured genera of Liparida; costal vein of primaries terminating at about the third fourth of costa; subcostal five-branched, the first branch emitted before the end of the cell, and the four others form a long footstalk; of these four short branches the first and fourth start almost from the same point, but from opposite sides of the vein, the first running to costa, the last to outer margin, and the intermediate pair form a short fork to apex; upper radial emitted from the anterior angle of the cell, lower radial from the posterior angle, where it appears as a fourth median branch; discocellular veinlet inangled; median branches nearly equidistant; secondaries short, subpyriform; costal vein running to apex; discoidal cell short, not reaching the middle of the wing; subcostal vein forked from a long footstalk at one-third the distance between the cell and outer margin; disco-cellular extremely slender, inangled; no radial vein; second and third median branches emitted from a short footstalk; head and thorax clothed with woolly hair; palpi depressed ; antennæ short, pectinated; abdomen with a large anal tuft; legs tolerably robust, clothed somewhat sparsely with long silky hairs.

In the branching of the subcostal nervure of the primaries, the forking of the subcostal and median veins of secondaries, and the total absence of a radial vein in these wings, this genus is most abnormal.

\section{Chionophasma paradoxa, n. s.}

q. Wings semitransparent snow-white, with a faint silky gloss; two very slender greyish lines on the fringe; body white, sparsely scaled; abdomen with golden ochraceous anal tuft; under surface coloured as above. Expanse of wings, $32 \mathrm{~mm}$.

\section{Rockhampton.}

This species was sent as the female of the succeeding Porthesia, to which, in common with many other Liparida, it bears considerable resemblance ; an examination of the structure would, however, convince the most sceptical that there is no relationship between them. 


\section{Ponthesia, Steph. \\ 6. Porthesia aliena, n. s.}

Primaries sericeous snow-white; costal margin towards the base golden brown; secondaries white, the veins broadly suffused with pale testaceous, giving the wings a creamy tint; thorax white, antennæ with pale brown pectinations; abdomen, excepting at base, yellowish barred with black; anal tuft ochreous; wings below white, slightly yellowish at the borders; basal half of costal border of primaries dark brown; pectus white; palpi and front of anterior legs ochreous, legs otherwise cream-coloured; venter ochreous. Expanse of wings, $30 \mathrm{~mm}$.

Peak Downs.

Allied to $P$. similis of Europe.

LEPTOCNERIA, n. g.

Most nearly allied to Ocneria of Europe (O.rubra), but differing as follows:-Primaries comparatively longer, with more oblique and less regularly convex outer margin; costal vein extending to about the second-third of costa; subcostal with five branches, the first branch emitted considerably before the end of the cell and almost uniting with the second branch at some distance beyond the cell; second branch emitted from the anterior angle of the cell, extending to the apex and throwing off the fourth and fifth branches from its inferior edge; the fifth branch is emitted at some distance beyond the cell and opposite to the point where the first and second branches almost unite; the fourth branch is emitted much nearer to outer margin; the radials are emitted from opposite angles of the cell, the lower radial (as in Ocneria) forming a fourth median branch; disco-cellular concave; median branches almost as in Ocneria; secondaries with the costal margin convex and the subcostal branches emitted from a footstalk; otherwise as in Ocneria; woolly frontal tuft longer; palpi much longer and less hairy; tibial spines of hind legs nearer together; antennæ more strongly pectinated.

\section{Leptocneria binotata, n. s.}

Whitish grey; primaries with a dusky-margined white spot just beyond the middle of the cell, and a second reniform spot at the end of the cell; these spots are enclosed between the two usual stripes, which are grey, a little darker than the ground colour inner stripe slightly irregular, dentated, outer stripe dentate-sinuate, 
inarched towards costa, otherwise parallel to outer margin; an illdefined submarginal macular stripe; fringe dusky spotted with sordid white; secondaries with pale fringe; thorax in front slightly brownish, antennæ with ferruginous pectinations; under surface of wings pearl-grey, the borders tinted with golden brown; no markings; pectus whitish; legs and venter pale brown. Expanse of wings, $41 \mathrm{~mm}$.

Peak Downs.

\section{LASIOCAMPIDE.}

Cosmotriche, Hïbn.

\section{Cosmotriche indistincta, n. s.}

9. Allied to C. exposita of Lewin,* but paler; wings of a semitransparent smoky grey tint; primaries a little darker than secondaries, with an abbreviated indistinct dusky oblique stripe across the middle of the interno-median area, and traces of a submarginal series of dusky spots upon the veins; head and front of collar blackish, centre of thorax dusky, abdomen brown; antennæ with testaceous pectinations; body below smoky-brown; wings more uniform in tint than above, wholly destitute of markings. Expanse of wings, $32 \mathrm{~mm}$.

Peak Downs.

\section{Pinara, Walk.}

This was described as a genus of Arctiida ; the typical species, $P$. cana, consisted of the females of three species of Walker's genus Entometa, placed by him in the Psychida; the female of a fourth species was, however, referred to its proper family, and placed in the genus Opsirhina.

\section{Pinara rufescens, n. s.}

7. Intermediate in character between $P$. divisa and $P$. sesioides, but with the secondaries of a uniform rufous-brown tint; primaries with the basal two-fifths to submedian vein and the costal area to lower radial vein reddish chocolate; remainder of the wing pale rufous-brown, sparsely irrorated with cream-coloured scales; a straight transverse creamy yellowish stripe across the basal fifth from costa to submedian vein; a white transverse spot across the end of the cell; a whitish stripe across the middle of the disc, incurved towards costa, lunulated and interrupted by the

* This species was redescribed by Walker under the names of Poecillogaster hebes and P. brevis; Boisduval's Bombyx myceria may be the same moth. 
veins below the lower radial; four small orange spots, externally dotted with black just beyond the discal stripe on the median and interno-median interspaces; external border greyish; body pale rufous-brown, head and collar darker, antennæ blackish; anal tufts tipped with bright reddish chocolate; wings below paler than above, primaries with no stripe across the basal fifth; the discocellular spot pure white; the discal stripe abbreviated, not extending below the third median branch, pure white; pectus smoky brown, venter bronze-brown. Expanse of wings, $36 \mathrm{~mm}$.

Rockhampton.

\section{LIMACODIDA. \\ Doratifera, Westw. \\ 10. Doratifera ordinata, n. s.}

Ochreous; primaries pale, irrorated with the usual shining scales; a pale rust-red subbasal spot; an oblique interrupted series of ill-defined rust-red spots across the middle, and a discal arched series of ten well-defined ferruginous spots parallel to outer margin; tegulæ whitish spotted with reddish ochreous; centre of thorax reddish ochreous; under surface pale sericeous-ochreous, costal borders darker; legs ochreous barred with whitish. Expanse of wings, $33 \mathrm{~mm}$.

Peak Downs.

Not near to any species known to me.

\section{NYCTEOLIDE. \\ EARIAs, Herr.-Sch. \\ 11. Earias smaragdina, n. s.}

Closely allied to $E$. chlorana, but the costal margin of primaries shorter and the outer margin consequently less oblique, the primaries of a clearer emerald-green tint, costal border pale peagreen instead of white; no orange margin towards the base of the costa; external border darker green instead of yellowish; secondaries of a less pearly white tint, more or less sordid, especially towards outer margin; head and collar of a yellower tint; under surface of primaries grey excepting at the margins, costal border cream-coloured, external margin greenish; fringe white; secondaries and body below white. Expanse of wings, $11 \mathrm{~mm}$.

Peak Downs. 


\section{COSSID卌.}

\section{Acritocera, n. g.}

Nearest to the S. American genus Langsdorfia, but with somewhat the aspect of a Notodont; primaries with the costa nearly straight, apex rounded; outer margin oblique, very slightly convex, rounded off at external angle; inner margin incurved at base, otherwise nearly straight; all the veins separate; costal vein extending to a little beyond the middle of the margin, subcostal five-branched, emitting its first branch at about half-way between the base and apex; a little beyond this the vein runs obliquely downwards and emits its other four branches near together, and at about equal distances apart; upper radial emitted near to the fifth subcostal branch from the end of the cell, having the appearance of a sixth branch; the lower radial also bears a similar relation to the third median branch, the second and third median branches and the lower radial being equidistant; disco-cellular veinlet zigzag, emitting two short recurrent veins; submedian vein slightly curved outwards towards the base; secondaries with long and very slightly curved frenum; costal margin rather deeply sinuated towards the base and convex in the middle; apex rounded; outer margin slightly convex; abdominal margin short, rounded off at anal angle; costal vein nearly straight, very slightly arched, very thick towards the base; subcostal vein slender, slightly arched to end of cell and then straight to apex, simple, its second branch having passed round to the end of the cell and thus become an upper radial; lower or true radial emitted near to the third median branch, thus having the aspect of a fourth branch; disco-cellulars unequally zigzag, emitting one short recurrent vein; third median emitted from the inferior angle of the cell, second branch running close to the main vein for a considerable distance towards the base, first branch emitted near to the base, sinuous towards its origin; submedian and internal veins widely separated; body very robust; head broader than long, with a keeled frontal crest; eyes large and prominent ; palpi broad, with closely appressed scales, apical joint deflexed; antennæ reaching to about the middle of costa, broadly plumose in front, disordered, basal joint tufted, thorax broad, less convex than in most Cossida above; legs very thick, middle tibiæ terminating in a long spur, posterior tibiæ with two subterminal and two terminal spurs; abdomen broad, tapering and somewhat flattened, especially towards the anal extremity; anal tuft very small. 


\section{Acritocera negligens, n. s.}

Primaries brown, the veins slenderly blackish, the whole of the internervular areoles longitudinally streaked with blackish and dark brown; an oblique pale testaceous stripe beyond the middle; secondaries pale brown; body brown, head and antennæ whitish, palpi with blackish terminal joint; wings below pale brown, irregularly mottled with patches of dark brown scales. Expanse of wings, $41 \mathrm{~mm}$.

Viti Islands.

The character of the antennæ in this species is so peculiar that it at once arrests the attention; in some respects it resembles that of Ereuxa (Amphidasyida), and still more nearly that of Ptilophora (Notodontida), but the feathering in Acritocera is much less orderly, and is confined to one side of the shaft.

\section{LEUCANIID Æ.}

Leucania, Ochs.

\section{Leucania diatrecta, n. s.}

Pale creamy stone-colour; primaries above with a brown $<$-shaped marking at base, its upper fork resting upon the median vein, irrorated with black scales, and forming the commencement of a slender dusky median streak, which extends beyond the cell almost to the middle of the disc, but is interrupted at the inferior angle of the cell by a black and white dot; a slender blackish streak along the internal margin, but not extending to the base; fringe slightly greyish, preceded by a marginal series of black points; secondaries semitransparent sericeous-white, with illdefined greyish apical external border and fringe, tapering towards the first median branch, where it ceases; a white line at the base of the fringe; a short blackish streak on the inner fringe of the tegulæ; primaries below with marginal black dots and greyish fringe, otherwise without markings; secondaries with six internervular marginal black dots; antennæ below ochraceous. Expanse of wings, $29 \mathrm{~mm}$.

\section{Peak Downs.}

\section{Leucania lewinii, n. s.}

๙. Primaries above whity brown, irrorated with black scales; a broad brown longitudinal median streak, divided by a slender white stripe, which runs along the median vein and its third 
branch; a creamy whitish longitudinal streak immediately above the median streak; a marginal series of black dots; apex dusky; secondaries silvery white; thorax whitish stone-colour, abdomen white; primaries below and costal border of secondaries creamy whitish, remainder of secondaries pure white, all the wings with marginal black dots; body below white, antennæ below dark brown. Expanse of wings, $28 \mathrm{~mm}$.

Gayndah.

\section{Leucania scottii, n. s.}

Primaries above cream-colour; veins whitish margined on both sides, from the middle of the wing, with ferruginous, internervular folds also indicated by longitudinal ferruginous lines; a broad longitudinal ferruginous streak, enclosing an ill-defined grey stripe, commencing below the median vein, which interrupts it at the end of the cell, where it passes into the upper radial interspace; two black discoidal dots just above the median vein, the second within the inferior angle of the cell; a marginal series of black dots; fringe greyish, paler at the extremities of the veins; secondaries sericeous-white, with greyish external border, especially towards apex, where there are also indications of blackish marginal dots; body white; antennæ greyish; primaries below flesh-coloured, with the base and internal area white, secondaries white with flesh-coloured apex; body white, tarsi blackish; venter with lateral black dots. Expanse of wings, $27 \mathrm{~mm}$.

\section{Rockhampton.}

\section{Leucania cruegeri, n. s.}

đ. Vaguely resembles the genus Epimecia; primaries above cream-coloured, the veins from the middle of the wing silvery white, slenderly edged on both sides with greyish brown; the internervular folds also indicated by slender greyish brown longitudinal lines; a broad silvery white longitudinal discoidal stripe edged below with brown; above and beyond this is a creamcoloured stripe, tinted with ochraceous, and running obliquely upwards from the end of the cell to the apex; fringe with two unequal brown stripes; secondaries semitransparent, white, tinted with greyish towards outer margin ; fringe white, with a brownish stripe towards the base; thorax white, antennæ and abdo. men cream-coloured; primaries below shining cream-coloured; secondaries shining white; body below white, anal tuft slightly yellowish. Expanse of wings, $31 \mathrm{~mm}$.

Gayndah. 


\section{Leucania alarioides, n.s.}

Primaries above rose-pink, divided in the middle by two broad longitudinal creamy white bands, the upper one passing from outer margin through the upper radial interspace into the cell, where it tapers to a point near the base, sometimes bounded on each side by a dusky streak; lower band filling the median interspaces and continued below the median vein to the base, where it is somewhat abruptly pointed, being bounded by the upcurved submedian vein; fringe white, traversed by two rose-coloured stripes; secondaries sericeous-white, with rose-pink veins; fringe slightly pink at apex; head dull vinous, collar greyish, thorax white, tegulæ rose-tinted on the shoulders; abdomen white; wings below shining creamy white; primaries with the veins pink; median area clouded with fuliginous-brown; fringe rosy lilacine; secondaries with rosy costal margin; fringe pure white; pectus silvery white, legs dull rose-colour varied with silvery white, abdomen silvery white, becoming sordid towards anal angle and banded with rosy lilacine. Expanse of wings, $29 \mathrm{~mm}$.

\section{Peak Downs and Gayndah.}

This is one of the most delicately-coloured species in the genus, agreeing in tint with some species of Alaria.

\section{EuRYPsyche, n. g.}

Allied to Leucania, with which it agrees in neuration, excepting that the veins are wider apart owing to the greater width of the wings; antennæ finely ciliated; body more slender than in Leucania.

\section{Eurypsyche similis, n. s.}

ð. Wings above silvery greyish white; primaries pale vinousbrown towards apex of costal border; basal half of costal border, interno-median area, and internal border irrorated with scattered black scales; a central longitudinal brown streak commencing with a blackish line below the median vein (which is white), then passing, as a narrow dark brown streak, immediately above the median vein to the base of the lower radial interspace, where it is interrupted, continued again as a blackish line in the upper radial interspace; an ill-defined flesh-tinted streak in the cell, bounding the upper edge of the central longitudinal streak; a marginal series of black points; secondaries slightly darker towards outer margin; a marginal series of elongated dusky dots; fringe whitish, traversed 
by a grey stripe; body white, antennæ pale bronzy brown; primaries below and costal and external borders of secondaries shining pale brown; a marginal series of black dots; remainder of secondaries silvery white; pectus pale brown; venter white. Expanse of wings, $30 \mathrm{~mm}$.

\section{Gayndah.}

In general tint and pattern this species much resembles Leucania lewinii, but the differences of structure will at once separate it.

\section{CARADRINID无.}

Caradrina, Ochs.

\section{Caradrina striolata, n. s.}

Primaries above dull copper-brown, costal border dull whity brown, bounded below by a diffused blackish streak, which passes through the cell and then obliquely upwards to apex; a zigzag black line across the basal fourth ; reniform spot small, outlined in black, and immediately followed by a transverse irregularly undulated black discal line from subcostal vein to inner margin; a series of unequal longitudinal discal black dashes upon the veins, and a marginal series of black dots commencing at outer third of costal margin; fringe grey, spotted with yellowish at the base and flecked with white; secondaries creamy white, with a slender dusky marginal line towards apex, and two greyish spots traversed by a darker line on the fringe; head and front of collar dull whitish; thorax fuliginous-brown; abdomen whitish; primaries below pale shining bronze-brown, the dise in some lights changing to ash-grey ; internal area whitish; fringe blackish, with pale basal dots; secondaries pearly white, with a broad costal brown border not extending quite to the base; pectus white; legs and venter pale greyish brown. Expanse of wings, $25 \mathrm{~mm}$.

Viti Islands.

Belongs to the same group with $C$. cubicularis, of Europe.

\section{Radinogoes, n. g.}

Allied to Caradrina, but differing in its narrower primaries and in neuration, which is that of Hydrilla (H. palustris), the subcostal branches and the second and third median branches of the secondaries being emitted from footstalks ; the palpi sufficiently distinguish this genus from Hydrilla, as they are gently curved upwards and not fringed. 


\section{Radinogoes tenuis, n. s.}

General aspect of Caradrina cubicularis, but much smaller; primaries cupreous-brown; discoidal area dusky, excepting for a central longitudinal line, on which are two small black spots, indicating the orbicular and reniform spots; a deeply zigzag black line across the basal third, and a very ill-defined curved denticulated line bounded externally by a pale cupreous-brown stripe across the dise just beyond the cell; a marginal series of alternate black and pale cupreous dots; fringe dark grey; secondaries pearly white; veins and a slender marginal line cupreous-brown; apex suffused with pearl-grey; head and thorax cupreous-brown; abdomen white; primaries below silvery whitish; costa and fringe grey-speckled; secondaries pearly white; costa grey-speckled; body whity brown. Expanse of wings, 21-24 mm.

Peak Downs; Rockhampton.

\section{COSMIIDE.}

\section{Leucocosmia, n. g.}

General aspect of Orthosia, but much paler ; allied to Enargia (E. abluta), but the primaries narrower, and the antennæ, with the exception of the basal joint, very slender, filiform, tapering.

\section{Leucocosmia ceres, n. s.}

๘. Primaries above pale sericeous sandy brown, almost golden, crossed towards base by three irregularly zigzag stripes formed by somewhat contorted double lines of brown, duller and darker than the ground colour; a transverse brown stripe, dentate-sinuate externally, crosses the wing just beyond the middle; between this and the basal stripes is a black discoidal dot indicating the orbicular spot, and at the end of the cell (bounded internally by the post-median stripe) is a small unciform whitish spot representing the reniform spot; external two-sevenths dusky, darker than the ground colour, bounded internally by a cream-coloured slightly sinuous stripe, beyond which are two parallel darker brown lines; a submarginal trisinuate whitish stripe; a marginal series of minute black dots; fringe creamy white, with dusky brown external edge; secondaries pearly hyaline whitish, the veins and broad diffused external and abdominal borders pale sericeous goldbrown; body pale brown, slightly greyer than the primaries, below whity brown with golden reflections, markings of the upper surface 
almost obsolete; secondaries with an oblique discal series of blackish dashes on the veins; otherwise as above; body below whitish. Expanse of wings, $31 \mathrm{~mm}$.

\section{Viti Islands.}

\section{Dysbatus, n. g.}

Allied to Cosmia, but with more nearly the coloration of the Homopterida; primaries triangular; costal vein extending to about third fourth of costal margin; subcostal vein five-branched, emitting its first branch before the end of the cell, its second to fourth at a considerable distance beyond, the third and fourth forming a rather short fork to apex, the fifth emitted from the posterior margin of the main vein a little before the emission of second branch from the anterior margin; the upper radial emitted from the anterior angle of the cell, and the lower radial from about the middle of the disco-cellulars, which form a concave line; median vein swollen and sinuous towards the base; second and third median branches emitted from the same point at the posterior angle of the cell; secondaries subpyriform, the costal and abdominal margins nearly straight, and the outer margin rounded and sinuated; costal vein running close to the subcostal to about the middle of the cell, and thence diverging to apex; subcostal forking from the anterior angle of the cell; radial obsolete, replaced by a slender longitudinal fold from base to outer margin; disco-cellular veinlet inarched; second and third median branches forking from the posterior angle of the cell ; thorax broad, rounded; head broad, palpi short, compressed, with sharply defined quadrate fringe at the base, porrest; proboscis long and thick; antennæ slender, tapering, internally pectinated; legs long, femora flattened, posterior tibiæ broad and flat, abdomen slender, laterally tufted.

\section{Dysbatus singularis, n. $\mathrm{s}$.}

Primaries above cinereous, tinted with pale brownish towards base and external area; crossed by six black lines, the first subbasal, oblique, the second at basal third curved, the third just before the middle angulated upon the median vein and inarched below it, the fourth crossing the disc like the third, but less strongly angulated, the fifth very irregular, thick, undulated and dentated, limiting the external area, the sixth submarginal, ill-defined, excepting at apex, where it commences with an oblique black dash costal border, excepting at apex, and a spot at the end of the cell, dusky; an interrupted black marginal line; fringe whitish spotted with grey; secondaries greyish white, slightly sericeous, with a 
broad dusky external border tapering to anal angle; fringe greyish white; thorax and base of abdomen cinereous; remainder of abdomen fuliginous-grey, with narrow white segmental bands; under surface sericeous-white, the wings irrorated with black-brown scales, especially towards the costal margins; a broad blackish external border, fading to grey towards the externo-anal margins, and with a whitish apical spot; fringes grey, white at base; legs grey-speckled, the tibiæ and tarsi almost entirely dark grey. Expanse of wings, $28 \mathrm{~mm}$.

Peak Downs.

This species bears but little external resemblance to its allies.

\section{PLUSIID杫.}

Westermannia, Hübn.

23. Westermannia argentata, n. s. .

Primaries above silvery white; secondaries pearly subhyaline, the costal area with brassy reflections; veins smoky grey; external border smoky grey, diffused, fringe dark grey; thorax pure pearlwhite, collar bright orange in front; abdomen white, barred with smoky grey; primaries below dark smoky grey with golden reflections; costal border cream-coloured; secondaries pearl-white, with a slender blackish marginal line; fringe brownish at base; body below pearl-white; tibiæ cream-coloured; anal segment of venter whity brown. Expanse of wings, $33 \mathrm{~mm}$.

Peak Downs.

This species has the general aspect, but not the structure, of Metoponia.

\section{Westermannia concha, n. s.}

Allied to $W$. superba, much smaller; primaries silvery white washed with bronze towards costa; a narrower internal border, a large rounded spot at centre of interno-median area, and a broad external border gradually narrowing to apex leaden grey, partly edged and flecked with bronze-brown; an indistinct narrow white looped line, commencing on the costa before the middle, crossing the cell, bounding the interno-median spot and part of the external border as far as the upper radial, where it leaves it and returns to costa at apical fourth ; secondaries white, semitransparent, pearly except towards costa, where there are brassy reflections; veins and a well-defined external border tapering to a point at submedian vein smoky brown; fringe white; body pearl-whitish, collar 
buff-coloured; primaries below shining leaden grey; the internal area and a narrow line at base of fringe white; secondaries nearly as above, but the border leaden grey and the veins silvery; body below pure pearl-white; anterior femora grey in front, anterior tarsi broadly barred with grey. Expanse of wings, $26 \mathrm{~mm}$.

Peak Downs.

\section{XYLINID丑. Crambodes, Guén.}

25. Crambodes minor, n. s.

Considerably smaller than $C$. talidiformis, with pale costal area to primaries and brownish secondaries; primaries above silvery grey, darker and with bronze-brown reflections in an oblique line from the inferior angle of the cell to the apex, so as to form an illdefined diffused streak, crossed by a black-edged tapering longitudinal cream-coloured streak from the reniform spot; discoidal cell and reniform spot also cream-coloured; a slightly curved longitudinal white litura in the cell just above the median vein; reniform spot white-edged, and enclosing a small brown spot below the median vein; a discal series of short black dashes upon the internervular folds towards outer margin; fringe blackish, interrupted by slender white lines in continuation of the veins; internal border cream-coloured towards base, two or three irregularly placed black or blackish subbasal longitudinal lines; secondaries shining pale brownish grey, slightly darker towards outer margin; fringe white, with a pale brownish subbasal line; thorax grey, abdomen whity brown; primaries below grey; secondaries cream-coloured, with a slender abbreviated black marginal line and white fringe; body below greyish white. Expanse of wings, $21 \mathrm{~mm}$.

Peak Downs.

CriOA, Walker.

\section{Crioa acronyctina, n.s.}

Aspect of the genus Pharetra (Acronycta, part. auct.) ; primaries whitish cinereous, black-speckled; about six short oblique black abbreviated costal strix followed by the discal line, which is very irregular, commencing at the subcostal vein, running obliquely outwards almost to the upper radial vein, where it bends down at a sharp angle and runs transversely to the second median branch, where it again turns abruptly inwards and forms a deep sinus (through the centre of which the first median branch passes), then inwards again to meet the inner line, which is 3-shaped and continuous with the third costal stria; three subapical longitudinal

TRANS. ENT. SOC. LOND. 1886.-PART IV. (DEC.) $2 \mathrm{E}$ 
black striæ, the two upper ones crossed by a zigzag white line; a diffused white subapical dash below the black striæ ; median interspaces fuliginous-brown, enclosing longitudinal black striæ, and crossed by white lunate markings; a deeply dentate-sinuate slender black marginal line; fringe white spotted with fuliginous-brown; secondaries pale testaceous or whity brown with golden cupreous reflections, the veins, a discal line, and a broad external border greyish brown; fringe white; thorax brown, white-speckled and streaked with black; abdomen mouse-grey; under surface whitish, with faint cupreous reflections; disco-cellular spots lunate, two somewhat diffused discal arched stripes, the veins, and a slender marginal line greyish chocolate; tibiæ hairy, chocolate-tinted; tarsi black-barred. Expanse of wings, $34 \mathrm{~mm}$.

Peak Downs.

The genus Crioa appears to me to be allied to the European genus Lithocampa.

\section{ACONTIIDE.}

Aporocosmus, n. g.

Allied to Agrophila; with similar pattern; the thorax, however, smoother; the palpi longer, porrected, the veining of the wings somewhat different; costal vein of primaries extending to about the middle of the costal margin; subcostal four-branched, the fifth branch being emitted as a third radial from the anterior angle of the cell ; first subcostal branch emitted before the end of the cell, second running from the end of the cell to costa, third and fourth forming a short fork, the fourth running to apex; upper (in this case the second) radial emitted from the same point with the fifth subcostal branch (or first radial); lower or third radial emitted as a fourth median branch from the inferior angle of the cell ; first and second median branches wide apart; secondaries with the costal vein much swollen at the base, coalescing with the subcostal to beyond the cell, where it separates and runs obliquely to apex; the first branch of the subcostal vein thus appears to be merely a furca from the costal, and its second branch is emitted freely as a radial; the true radial is emitted as a fourth median branch at the same point with the third median and close to the origin of the second; disco-cellulars very oblique and angulated; first and second median branches tolerably wide apart; legs rather long and compressed. 


\section{Aporocosmus bracteatus, n. $\mathrm{s}$.}

Primaries above cream-coloured; markings red-brown, spangled with silver as follows : an interrupted oblique band and a spot at base, an oblique irregular band crossing the wing before the middle, a broader transverse irregular abbreviated band from costa to median vein across the end of the cell, a slightly sinuous discal band subparallel to outer margin, two short arched bands almost uniting at centre of outer margin, the inferior one interrupted, an interrupted marginal line, and a similar line on the fringe, which is white ; secondaries pale golden brown or "dead golden," with the costal area, excepting at apex, cream-coloured; a dark brown external border shot with gold, and therefore only visible in certain lights; the extreme margin irregularly pale yellow; fringe very long, cream-coloured, traversed by a slender interrupted brown line; body coloured in accordance with the wings, the thorax cream-coloured and spotted, the abdomen golden opaline; under surface pale stramineous, the primaries with indications of the markings of the upper surface in pale smoky brown; secondaries with a discal line of brown parallel to outer margin; pectus pearly whitish. Expanse of wings, $16 \mathrm{~mm}$.

\section{Peak Downs.}

\section{Acontia, Ochs.}

\section{Acontia amorpha, n. s.}

Allied to A. signifera of India, from which it chiefly differs in its slightly superior size and paler golden brown banding of the primaries; it also differs in showing traces of stripes across the basal area, in having two spots, the lower one black, in place of the black crescent in the reniform spot, and the secondaries decidedly darker. Expanse of wings, $18 \mathrm{~mm}$.

\section{Gayndah.}

Specimens of this species from Moreton Bay stand in the collection under a MS. name of Walker's.

\section{Acontia vitiensis, n. $\mathrm{s}$.}

Also allied to A. signifera; primaries above pearl-white, crossed in the middle by a broad cupreous-brown band with dentate sinuate edges, the inner edge bounded by a black line; reniform spot indicated by a cupreous-brown 3 -shaped marking beyond the cell, and a corresponding black linear marking just beyond it at the edge of the external border; the latter broad, cupreous-brown, dotted with white on costal margin, flecked with black and white 
towards the outer margin, along which is a reddish cupreous stripe; fringe white; secondaries sericeous creamy whitish, with diffused cupreous-brown external border and an ill-defined stripe of the same colour on the fringe; thorax white flecked with cupreousbrown, abdomen brown in type (sometimes cream-coloured flecked with brown); primaries below greyish with pink reflections; secondaries sericeous creamy whitish, suffused with pink towards costal and external margins; pectus pearl-white, legs pale fleshbrown, anterior legs greyish above; venter whitish. Expanse of wings, $21 \mathrm{~mm}$.

Viti Islands.

Also in the Museum from Moreton Bay; it is nearly related to the "Erastria" ritseme of Snellen.

\section{Acontia tripartita, n. s.}

Allied to the preceding species; primaries pure white, divided by two transverse equidistant undulated chocolate-brown bands into three nearly equal parts, the inner band of about half the width of the outer, the latter expanded into an oblong spot upon the costa; a blackish costal spot near the base; an irregular submarginal brown line and a slender black-brown marginal line; fringe flecked with brown; secondaries sericeous, cream-coloured, broadly suffused with grey towards outer margin; an interrupted slender dark brown marginal line; thorax cream-coloured; abdomen greyish, especially in the middle; primaries below smoky grey; apical third of costal border black spotted with ochreous; secondaries pale creamy ochreous, changing in certain lights to silvery greyish; costal area irrorated with blackish; a black spot at the end of the cell, and an angulated discal stripe beyond it from costa to submedian vein; all the wings with a very slender black marginal line; body below ochreous. Expanse of wings, $15 \mathrm{~mm}$.

Rockhampton.

31. Acontia nivipicta, n. s.

Allied to A. maculosa of China and A. tetragona of St. Domingo. Primaries above deep olivaceous, shading into cupreous-tinted chocolate-brown towards outer margin; interno-median area glossed with lilac and crossed by four interrupted oblique bands of the ground colour; a large quadrangular snow-white patch at base, and upon it, close to the base, four unequal dark olivaceous spots; three black dots along the infero-exterior margin of the basal 
patch; two snow-white costal patches, the first larger than the second, its margin denticulated and bounded on each side by the discoidal spots, which are black and annular; three black spots bounded externally by a rectangular red-brown marking beyond the cell; an irregular line of white scales crossing the disc towards outer margin, partly enclosing two black dots towards costa, confluent, and forming an oblique dentated line towards external angle; a submarginal series of black spots with white internal borders; a large white spot on the fringe below the middle and a narrow whitish dash crossing it longitudinally at apical third; the remainder of the fringe is divided by a central blackish line, beyond which it is glossed with grey; secondaries straw-yellow, with a broad external brown border; basal half of fringe occupied by a brown stripe, separated from the external border by an ochreous line; outer half of fringe white; thorax white, the collar slightly sordid; abdomen ochreous banded with brown, the base and anus white; wings below stramineous; primaries clouded with grey, indicating the pattern of the upper surfaee; secondaries with three dark grey costal spots, shot with rosy cupreous, the third at apex, almost confluent with a dark spot on the fringe; body below white. Expanse of wings, $22 \mathrm{~mm}$.

\section{Peak Downs.}

\section{Acontia detrita, n. s.}

Allied to the preceding species; primaries above with the basal patch reduced to a basal spot on the costa, the two other costal spots smaller than in $A$. nivipicta; all three spots slightly yellowish; indications of an oblique yellowish stripe connecting the central spot with the inner margin; black markings on the wings less sharply defined; the discal line of white scales not terminating in a dentated line as in A. nivipicta, but uniform throughout; no large white spot on the fringe, the latter creamcoloured, marked with three dusky spots, one at apex, one above the middle, and one at external angle; secondaries bronze-brown, greyish towards the base; body whity brown; primaries below smoky grey, with a golden gloss; costal border white at base, otherwise ochreous, interrupted beyond the cell; internal border cream-coloured; secondaries pale golden stramineous; a spot at end of cell, an angular discal stripe, and a tapering marginal stripe dusky; fringe greyish; body below white. Expanse of wings, $19 \mathrm{~mm}$.

Gayndah. 


\section{Acontia clarissa, n. s.}

General pattern of $A$. Komaga, but smaller and with yellow instead of white basal area and costal spot; primaries with the basal half pale creamy yellow, irregularly variegated with chromeyellow; the inner border and two or three longitudinal costal dashes leaden grey; external half purplish brown internally, pale reddish brown externally, the division between the two halves of the wing oblique and biangulated; reniform spot indistinct, yellowish, followed by a blackish $>$-shaped character; a small yellowish white costal spot at apical fourth; a very indistinct submarginal zigzag whitish line; fringe white, flecked with black towards apex, and with a brown patch at external angle; secondaries bronze-brown, with the basal half pale; fringe tipped with white; thorax yellow in front, greyish behind; abdomen whity brown, with a dusky dorsal stripe; under surface as in the preceding species. Expanse of wings, $24 \mathrm{~mm}$.

\section{Peak Downs.}

\section{Acontia conchidia, n. s.}

Primaries above chalky white; costal margin to the end of the cell divided into three equal parts by small black dots; edge of costal margin black; an abbreviated black-speckled brown band, with undulated internal and dentate-sinuate external margin from the inner margin to the base of the third median branch, a small spot similarly coloured just above the median vein, from which a straight line of black runs across the cell to the subcostal vein; a large irregular French-blue patch, with black external border immediately beyond the cell; a subsigmoidal discal bronze-brown stripe varied with plumbageous across the disc; external border narrow, of the same colours, excepting that the brown is of a more orange tint; a marginal series of small black spots ; fringe white, traversed by central and external greyish stripes, and spotted at the extremities of the veins with sandy brown; secondaries creamcoloured, with diffused golden brown external border and white fringe spotted towards apex with golden brown; thorax white, abdomen testaceous; wings below creamy white with brassy reflections, primaries with a brown spot on the inner margin near external angle; secondaries with a brown apical spot; body below pearl-white; venter with lateral blackish dots and pale stramineous anal tuft. Expanse of wings, $28 \mathrm{~mm}$.

Peak Downs. 


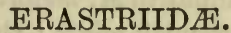 \\ Erastria, Ochs.}

\section{Erastria fasciolata, n. s.}

Primaries above dark fuliginous-grey, traversed by numerous subparallel black undulated lines; a number of interrupted undulated ash-grey stripes between the black lines; an irregular white band tapering to costal margin across the basal third, a white costal spot at apical third, two white costal dots between the latter and the apex, a widely interrupted submaarginal series of white dots and an oblique squamose white spot at the external angle; a slender black marginal line formed by the confluence of subconical black spots ; fringe white at apex, otherwise brown dotted with white; secondaries fuliginous-grey, with bronze reflections; a black marginal line; fringe cream-coloured, traversed by a grey stripe; thorax dark fuliginous-grey, with lateral white dots on the collar; abdomen cream-coloured at the sides, a broad dark grey dorsal band traversed by slender whitish segmental lines; primaries below sericeous-grey; basal two-fifths of costal area cream-coloured, with scattered black scales on the costal margin; a quadrate white spot at about the apical third of costa, and indications of a pale stripe in continuation of it across the disc; a submarginal series of white dots and a marginal series of indistinct cream-coloured dots alternating with the confluent conical black spots ; fringe dark grey, with the apex, external angle, and a basal line cream-coloured; secondaries with the basi-abdominal area silver-grey, two large white discoidal spots; remainder of wing dark fuliginous-grey, crossed beyond the middle by an irregular white band; a submarginal irregular interrupted white line; fringe silver-grey, with a white basal line; body below cream-coloured. Expanse of wings, $15 \mathrm{~mm}$.

\section{Peak Downs.}

\section{ANTHOPHILID王.}

\section{Metachrostis, Hïbner.*}

36. Metachrostis paurograpta, n. s.

General size and coloration of M. mendaculalis, but without the undulated ash-grey lines on the secondaries; the primaries with all the transverse lines blacker, making the ground colour appear to be lighter; these lines are also less oblique and more irregular;

* This is the Leptosia of Guenee, a name preoccupied in the Butterflies. Scudder argues, upon what I think are unsatisfactory grounds, that Leptosia is a synonym of Leptidia. 
under surface also very similar to $M$. mendaculalis, but the internal border of the primaries greyish white; the secondaries decidedly whiter, with the two abbreviated dusky stripes from the costa rather better defined; palpi with longer terminal joint, the distal half black, crossed by a whitish line between the joints. Expanse of wings, $18 \mathrm{~mm}$.

\section{Rockhampton:}

\section{Thalpochares, Lederer.}

\section{Thalpochares leonata, $\mathrm{n}$. s.}

Allied to $T$. partita of Java; stramineous; primaries with the external half brownish testaceous, crossed along its inner edge by an externally waved darker and somewhat lilacine band, and margined internally by a white and black line; a submarginal series of black dots; external border narrowly greyish, tapering at the extremities, bounded internally by a white line; fringe broad, flesh-pink, irrorated, excepting along the outer edge, with red-brown; costa slightly redder than the ground colour; secondaries with a diffused externo-discal ferruginous stripe, only well-defined towards the abdominal margin; slender marginal and submarginal ferruginous lines; fringe whitish, traversed by a slender pale brownish line, and margined with the same colour; wings below ochreous, irrorated with ferruginous towards the apices; internal borders whitish; costal margin of primaries from beyond the middle to the apex blackish spotted with white; legs whitish. Expanse of wings, $15 \mathrm{~mm}$.

\section{Rockhampton.}

\section{Thalpochares pusilla, n. s.}

Somewhat allied to $T$. parva, though altogether more brightly coloured; primaries with the ground colour whity brown, crossed before the middle by an internally diffused oblique castaneous band, its outer edge sharply defined, followed almost immediately by an internally diffused greyish band, its outer edge bounded by a darker sinuous discal line; a broad patch of castaneous below the apex, and a second at external angle, with a slender arched connecting line of the same colour; four submarginal white dots, the three upper ones crossing the subapical patch, and the fourth upon the inferior patch; a marginal series of blackish dots followed by a white line at the base of the fringe; fringe pale grey with reddish reflections, white externally with a brown edge; secondaries whitish, becoming greyish brown towards outer margin; fringe 
white; body white; primaries below grey, with white fringe; secondaries and body white. Expanse of wings, $14 \mathrm{~mm}$.

Peak Downs.

\section{Thalpochares innocens, $\mathbf{n} . \mathrm{s}$.}

Wings above satiny whitish, with faint goiden reflections; primaries with the costal border snow-white towards the base; edge of costal and outer margins golden ochraceous; head and collar ochraceous; thorax glistening snow-white; abdomen pearlwhitish; under surface creamy whitish; primaries with the discoidal area slightly greyish, the costal and external borders slightly yellowish; pectus snow-white, legs and anus yellowish. Expanse of wings, $22 \mathrm{~mm}$.

\section{Peak Downs.}

Nearest to a Venezuelan species, T. debilis.

\section{ANTHOPHILA.}

40. Anthophila vestalis, n. s.

万. Snow-white; costal margin of primaries slenderly golden brown, four nearly equidistant brown-tipped oblique costal dashes beyond the middle, the third extended as a brown line to below the upper radial vein, where it is abruptly angulated, and runs inwards obliquely almost to the second median branch, below the angle, however, it is indistinct; the fourth costal dash is united to a fifth, but reversed, dash immediately beyond it; a subapical grey and golden spot crossed by the line from the third costal dash, and marked externally. with two connected black dots; an undulated narrow grey external border with dusky inner edge, in certain lights slightly shot with golden; fringe golden; outer margin of secondaries tinted with golden; head and collar ochreous; wings below satiny white, slightly tinted with golden ochraceous, especially towards costal and external margins; primaries with two black costal dots beyond the middle; body pearl-white, legs more or less ochraceous. Expanse of wings, $18 \mathrm{~mm}$.

Peak Downs.

\section{HELIOTHID ÆE.}

HeLiothis, Guenée.

41. Heliothis aberrans, n. s.

Not very near to any known species; primaries whity brown, with faint greyish indications of bands formed somewhat as in $H$. armigera ; blackish indications of a subbasal acutely zigzag 
line; two dusky spots placed obliquely at the end of the cell (indicating the reniform spot); an angulated series of short longitudinal black dashes across the disc, and a marginal series of black dots; secondaries greyish white, with a broad external grey border, upon which is the usual oval whitish spot; fringe cream-coloured, spotted with grey at apex; body greyish white; primaries below whity brown, with two spots in the cell and an arched band beyond it grey; secondaries and body below cream-coloured. Expanse of wings, $28 \mathrm{~mm}$.

\section{Peak Downs.}

\section{Canthylidia, n. g.}

Probably nearest to Heliocheilus, but with more nearly the general aspect of Heliothis or Leucania, especially in the form of the wings ; the primaries, however, have a swelling upon the costal margin beyond the middle, and the body is as slender as in the genus Micardia (Leucanida); primaries with the discoidal cell extending to beyond the middle of the wing; costal vein terminating in the costal swelling; subcostal emitting its first branch at some distance beyond the end of the cell, and the four others beyond it, the second and fifth from opposite sides of the vein, and the third and fourth as an apical furca; radials emitted from extremity of cell, not from the angles, lower radial emitting a recurrent vein through the cell to the base, the second and third median branches and lower radial about equally distant from one another at origin; secondaries with slightly sinuous costal vein extending to apex; discoidal cell reaching to about the middle of the wing; subcostals emitted from one point at the anterior angle of the cell, and the second and third medians from the posterior angle; disco-cellulars forming a regular concave arc, from the centre of which the radial is emitted; first median branch emitted near the end of the cell; body rather slender; palpi slender, porrected.

\section{Canthylidia pallida, n. s.}

Satiny whity brown, slightly darker towards the external borders of the wings, especially of the secondaries, which also show a faint indication of a disco-cellular spot; under surface cream-coloured; primaries with the disc slightly greyish. Expanse of wings, $26 \mathrm{~mm}$.

Gayndah.

The absence of the post-discoidal cell in the primaries proves this to belong to the Heliothide, and not the Leucaniidee. 


\section{Plusiodonta, Guenée. \\ 43. Plusiodonta arctipennis, n. $\mathrm{s}$.}

๙. General coloration of $P$. thoma, Guenée, from Haiti, but the metallic markings more golden, as in $P$. chalcitoides, from Java, with which it also agrees in having metallic markings near external angle of primaries; it differs from all the described species in its narrower wings; primaries reddish brown, more olivacaous upon the central area, tinted with lilac at base, centre of costa upon the reniform spot, and along the internal border of the discal line; ordinary lines blackish, the external line double; pattern nearly as in $P$. chalcitoides, the subbasal metallic patch brassy mottled with ferruginous; that at external angle sharply defined, quadrate, brassy, with the central ferruginous mottling flecked with gold; subapical biangulated fascia golden mottled with ferruginous; secondaries fuliginous-brown, getting whitish towards base; fringe tipped with sordid white; thorax chocolatebrown; head blackish; abdomen fuliginous, whitish at base and sides; under surface pale shining fuliginous greyish with bronzebrown reflections. Expanse of wings, $32 \mathrm{~mm}$.

Sydney.

GONOPTERIDÆ.

Gonitis, Guenée.

44. Gonitis samoana, n. s.

Nearest to G. involuta of Ceylon; primaries golden or cupreousbrown, glossed with pale lilacine-pink, especially upon the median vein and its branches and on the costal area at apex; ordinary lines dark brown, less irregular than usual; outer or discal line externally edged with whitish, straight from inner margin to cell ; external margin dark brown; orbicular spot represented by a white dot; reniform spot by two whitish-edged black dots placed obliquely at end of cell; secondaries pale dove-brown, whitish at base of costa ; fringe white-tipped; thorax foxy brown; abdomen dovebrown, slightly reddish at base; primaries below grey, with a rosy cupreous gloss; costal border sparsely whitish-speckled to beyond the cell, where the white speckling suddenly becomes dense, and forms a cuneiform apical patch separated by an oblique line from the remainder of the border; internal border creamy white; disc slightly and indistinctly striated with ash-grey; fringe whitishtipped, black-dotted below the angle; secondaries with the costal half and external border almost to anal angle grey, with a rosy cupreous gloss ; interno-median area creamy white; fringe whitish, traversed by a bronze-brown stripe; apical area indistinctly striuted 
with pale yellowish scales, making the apical third abruptly paler than the remainder of the dark portion of the wing; pectus whitish, tinted with foxy red; venter greyish chocolate. Expanse of wings, $35 \mathrm{~mm}$.

Samoa Islands.

\section{Gonitis vitiensis, n. s.}

9. Primaries above reddish chocolate or coffee-brown, transversely mottled with darker brown and black; inner line more or less abbreviated, only visible below the cell; outer line biangulated, forming a simple rectangular zigzag; both lines dark brown; a diffused discal whitish-cinereous belt bounding the outer line externally; a subapical subsigmoidal line immediately beyond the whitish band; external margin blackish; discoidal spots barely visible, the orbicular spot indicated by a white point, and the reniform by two black dots; secondaries fuliginous-grey, gradually paler towards base ; fringe of the outer margin with a slender white basal line, of abdominal margin wholly white; thorax red-brown, abdomen fuliginous-grey; under surface nearly as in the preceding species, but without the whitish apical costal patch. Expanse of wings, $36 \mathrm{~mm}$.

Viti Islands.

Var. ․ Darker than the type, and without any whitish band across the primaries. Expanse of wings, $36 \mathrm{~mm}$.

Viti Islands.

46. Gonitis vulpina, n. s.

Primaries above bright foxy red, decidedly brighter than the allied G. revocans of Australia, the lines across the wings similar in form, excepting that the central line is abruptly elbowed outwards from submedian vein, and that all the lines are a little better defined; orbicular spot prominent, small, rounded, creamy white; reniform spot represented by two small rounded grey spots; secondaries creamy whitish, with the veins and a broad external border dull rose-red or pale vinous; thorax bright foxy red, almost orange; abdomen whitish, banded with pale fuscous, slightly tinted with vinous at anal extremity; primaries below silvery whitish, washed with flesh-tint excepting along internal area, a diffused patch of dull rose-red covering the discoidal area; a whiteedged oblique vinous line crossing the disc; apical border golden brown, fringe darker brown; secondaries sericeous-white, with the costal area broadly irrorated with dull rose-colour; a darker 
bisinuated subapical line; pectus white, palpi and legs varied with foxy orange and dark vinous; tarsi brown banded with white; venter white at base, but with lateral dull rose-coloured tufts; remainder of venter pale flesh-brown, washed in front with ochreous. Expanse of wings, $49 \mathrm{~mm}$.

Viti Islands.

\section{Gonitis xanthochroa, n. s.}

Allied to G. privata from Shanghai ; primaries ochreous, crossed by four irregularly dentate-sinuate more or less diffused red-brown stripes of the usual character; an abbreviated dentate-sinuate blackish line from costa between the third and fourth stripe; orbicular spot small, white, with red-brown border; reniform spot red-brown, bounded externally by the third stripe; costal and external borders diffused, pale olivaceous; secondaries rosy ferruginous, paler towards the base ; fringe whitish; thorax ochraceous; abdomen pale flesh-brown; primaries below dull rose-pink, with the external border creamy yellowish, broadly suffused from apex to below the marginal angle with testaceous; fringe brown; an internally diffused subapical costal triangular brown spot, bounded externally by an oblique abbreviated darker brown zigzag line; an abbreviated arched line from costa beyond the cell; inner border cream-coloured; secondaries cream-coloured, with rose-tinted costal third, crossed beyond the cell by an arched brown line; body below creamy ochraceous, with the front of pectus, legs, and venter ochreous; under surface of legs white. Expanse of wings, $50 \mathrm{~mm}$.

Vanua Levu.

\section{POLYDESMIDE. \\ EURythMus, n. g.}

Allied to Diatenes, but reminding one rather of Bryophila; costal vein of primaries extending to about the apical fourth of costa; subcostal five-branched; first branch emitted at a considerable distance before the end of the cell, second branch emitted at a short distance before the end, united by an oblique cross-vein to the third branch, which is emitted from the anterior angle of the cell, giving off the fifth branch from its inferior margin at the junction of the cross-vein and forking towards apex; upper radial emitted near to anterior angle of the cell, the lower radial near to the posterior angle, and equidistant with the second and third median branches; lower disco-cellular veinlet inarched; costal vein of secondaries terminating before the apex; subcostal 
branches forking from anterior angle of the cell, a slender veinlike longitudinal fold passing through the cell to outer margin; disco-cellulars transverse, nearly straight; radial and second and third median branches emitted close together at the posterior angle of the cell; body very robust; palpi long, slender, curving upwards to above the level of the head; posterior femora flattened and longitudinally grooved; tibiæ broad, flattened, thickly scaled, bearing two pairs of unequal divergent spurs.

\section{Eurythmus bryophiloides, n. s.}

Primaries above pale sandy brownish, irrorated with fuliginousbrown, and with longitudinal pale sienna streaks along the veins; markings not unlike those on the primaries of Diatenes gerula, dark brown and black; a dentate-sinuate blackish submarginal line; fringe greyish, with a series of blackish spots opposite to the sinuations of the submarginal line; secondaries cream-coloured, becoming pearl-white at costa ; external border pale bronze-brown, diffused, a paler marginal dash near anal angle; a marginal subconfluent series of dusky lunules; fringe creamy white; body above whitish, front of thorax and collar irrorated with dark brown scales; under surface pearl-white; wings sericeous greyish towards external borders; a marginal series of grey-edged white triangular spots; primaries with the costal margin black-spotted towards apex. Expanse of wings, $28 \mathrm{~mm}$.

Peak Downs.

\section{Girpa, Walker.}

Nearly allied to Polydesma, and therefore incorrectly referred to the Remigiida.

\section{Girpa maxima, n. s.}

Testaceous; wings somewhat sericeous; two brown dots, one above the other near the base, a third within the cell beyond these, a series across the basal fourth, the lowest of them blackish; reniform spot indicated by pale reddish-brown dots; an ill-defined greyish stripe across the middle, followed by an ill-defined zigzag dentated line; a discal trisinuated subconfluent series of more or less triangular pale-centred ferruginous spots, towards apex passing into a cuneiform apical red-brown patch, crossed by a series of whitish scales; external margin and fringe suffused with redbrown; a marginal series of blackish dots; secondaries similar in pattern to the primaries; head and collar tinted with reddish brown; primaries below greyish, excepting towards outer margin, 
with a few traces of the markings of the upper surface; secondaries stramineous grey-speckled, crossed by three discal greyish stripes, the outermost macular and with pale outer edge; blackish marginal dots as above; body below pale testaceous. Expanse of wings, $56 \mathrm{~mm}$.

Vavao, Friendly Islands.

\section{Girpa carnea, n. s.}

Allied to the preceding species, glossy clay-coloured, with a pink tint; a faintly indicated irregular grey line across the basal fourth of the primaries; a black dot upon the line just below the submedian vein; two white dots at the end of the cell ; an irregularly trisinuated greyish line across the middle of the primaries, continued across the basal third of the secondaries; two parallel dentate-sinuate grey lines crossing both wings beyond the middle, and followed by a confluent discal series of externally white-edged orange spots; a submarginal series of black dots; under surface nearly as in the preceding species. Expanse of wings, $55 \mathrm{~mm}$.

Vavao.

The differences both in ground colour and in the details of marking are so great between this and the preceding species, that they can hardly be conspecific.

\section{HOMOPTERID E.}

Homoptera, Boisd.

\section{Homoptera cruegeri, n. s.}

Primaries above purplish brown, crossed by numerous blackishedged wavy oblique paler lines; external fourth whity brown, crossed near its inner edge by a clay-brown undulated stripe, washed with ochreous internally; a darker nebula in the centre of this area; base whity brown, traversed by a bisinuated dark brown line, and with a costal spot of the same colour; veins on the darker area of the wing slaty grey in certain lights; two dentatesinuate stripes immediately succeeding the ordinary discal line also shot with slaty grey; the two ordinary lines widely separated, irregularly dentated, very slender, black; a slender undulated black submarginal line; external margin and fringe wood-brown or brownish testaceous, with darker central stripe bounded by two slender sinuous whitish lines, the outer one indistinct; secondaries whity brown; five or six parallel internally diffused dentated dusky stripes with whitish external edges, followed by two slightly sinuous 


\section{2

convergent black lines enclosing a purplish brown stripe; external area purplish brown, with a nebulous blackish spot on the second median interspace, external margin and fringe as in primaries; body of different brown shades corresponding with those of the primaries; abdomen with three dorsal and two lateral subbasal tufts; under surface greyish stone-colour, with faint brassy reflections, especially on internal area of primaries; numerous subparallel slender brown lines, excepting across the basal area; three of these lines, across the disc of secondaries, more strongly defined than the others; a submarginal series of black dots; fringes tipped with reddish brown; tarsi black, banded with whitish. Expanse of wings, $48 \mathrm{~mm}$.

Gayndah.

\section{HYPOGRAMMID Æ.}

GADIRTHA, Walker.

52. Gadirtha pulchra, n. s.

Primaries above sericeous silver-grey, transversely striated with dark grey and black scales; basal area whitish, bounded by two transverse black lines, slightly divergent at costa ; three grey costal dashes, the second broad and oblique; orbicular spot pale sandy brownish; reniform spot large, outlined in black, enclosing, in its posterior half, a triangular grey-brown spot; two transverse black lines from first median branch to inner margin, the inner line throwing off a slender curved line at right angles to join the postmedian line, the outer line shorter, but also rectangular at its upper extremity; post-median line black, crossing the wing obliquely from costa to outer margin near external angle; a reversed oblique black dash from costa almost to the post-median line, incised at its extremity, and continued across the dise by a regular zigzag white line, the uppermost $>$-shaped division of which is edged with greyish; a marginal series of subconfluent black crescents ; fringe white, spotted with greyish at the base; secondaries subhyaline pearl-white, with the veins and a broad decreasing external border greyish brown with golden reflections, fringe pure white; thorax ash-grey, the collar crossed in front by a slightly arched slender black line; antennæ testaceous; abdomen silver-grey banded with white; primaries below greyish, becoming white on interno-basal area and faintly glossed with gold; costa creamy white from the end of the cell almost to the apex, with four elongate black spots on its anterior edge; a marginal series of small triangular black spots; fringe white, with a double series of greyish spots; secondaries pearl-white; a large cuneiform diffused costal spot or streak, and the external border greyish with golden reflections; body below 
white, tibiæ (excepting of the posterior pair of legs) crossed above by slender curved black lines, tarsi above black. Expanse of wings, $42 \mathrm{~mm}$.

Rockhampton.

This is the most distinctly marked species in the genus, in colour and marking not at all unlike Walker's genus Calathusa, though different in structure.

\section{OPHIUSID $\approx$.}

Pseudophia, Guenée.

\section{Pseudophia nebuligera, n. s.}

General coloration and size of $P$. illunaris of Europe, the prevailing tint on the upper surface being pale greyish with a creamy whitish subtint; costal border of primaries faintly shot with lilac; all the markings ill-defined, darkest on costa ; ordinary lines diffused internally, bounded externally by a creamy whitish stripe, the inner line at basal fourth, oblique, regular; outer line just beyond external fourth, slightly sinuous, undulated, olivaceous ; traces of a submarginal undulated line, olivaceous in the middle; ordinary spots obsolete; traces of a very irregular whitish-edged dusky line across the external third; fringe white, traversed by two broad greyish stripes; secondaries whitish, sordid towards the base; a curved grey litura at end of cell; a slightly oblique dark grey central stripe; external area dark grey, diffused internally, crossed from anal angle nearly to apex by a whitish stripe; a second abbreviated marginal whitish stripe at extremity of radial interspaces; a slender black marginal line; a nebulous dusky spot just below the middle of the external border, and extending into the fringe, which is otherwise creamy white; thorax grey in front, whitish behind; abdomen whitish, crossed by broad pale greyish bands; under surface creamy yellowish; markings similar in all the wings, the costal areas grey-speckled; disco-cellular spots narrow, blackish; a dark grey undulated arched post-median stripe, not reaching the inner margins, followed by a slightly irregular internally diffused, externally undulated, grey discal stripe; a large diffused apical greyish brown spot, and a second similar spot (almost black on the secondaries) just below the middle of external border; a slender undulated blackish marginal line; anterior and middle femora and tibiæ grey above. Expanse of wings, $38 \mathrm{~mm}$.

Peak Downs.

TRANS. ENT. SOC. LOND. 1886. PART 1V. (DEC.) 2 F 
Although this species agrees in its structural details with $P$. illunaris, the dark nebulous spot on the external border of the secondaries gives it somewhat the aspect of Cerocala.

Hypetra, Guenée.

\section{Hypcetra sordida, n. s.}

Primaries pale greyish brown, slightly suffused with lilacine, speckled and transversely striated with blackish grey; inner and central striæ indicated by ill-defined wavy blackish squamose stripes; discoidal spots obsolete; a clavate black spot below the submedian vein at basal third; a cream-coloured nearly straight line crossing the disc at external fourth; from this line tapering ferruginous streaks run outwards along the veins, but they are only strongly defined towards apex; immediately beyond the discal line is an interrupted and slightly irregular series of blackish spots; a marginal series of black dots; fringe whity brown; secondaries whity brown towards base; crossed beyond the middle by a slightly curved internally diffused greyish band; external border broad, of the same colour, and separated from the postmedian band by a whity-brown band a little paler than the basal area; a marginal series of blackish dots ; fringe sandy whitish; thorax pale fuliginous-grey; head and collar darker grey, the latter with dark brown borders; abdomen whity brown; under surface whity brown, costal areas slightly tinted with pale flesshbrown; central area of primaries, a disco-cellular spot, and two arched diffused bands on the secondaries, slightly greyish; palpi whity brown internally, dark brown externally. Expanse of wings, $45 \mathrm{~mm}$.

Viti Islands.

Somewhat resembles "Toxocampa orthosioides" of Walker from N. Australia; the latter is, however, synonymous with Pantydia recondita of Walker.

Hypcetra diffundens, Wlk., is Remigia virbia, Cram.

55. Ophiusa vitiensis, n. .

Allied to O. stuposa, Fabr., but differing as follows:-Primaries above suffused with lilac, the band before the middle much less white and decidedly narrower; the irregular dark olivaceous belt beyond it considerably broader, the second angulation of its outer edge much farther from the upper one; two dark olivaceous spots in the sinus between these two angles; the oblique apical patch not externally incised; the white band across the secondaries only 
indicated by a diffused greyish streak; a slender abbreviated oblique whitish anal stripe, well separated from the greyish patch on external border; the latter suffused with lilacine. Expanse of wings, $46 \mathrm{~mm}$.

Viti Islands.

\section{REMIGIID无.}

Remigia, Guenée.

\section{Remigia discrepans, n. s.}

$q$, Closely allied to $R$. archesia and $R$. mayeri; differing in the ochraceous clay-colour of the primaries, the costal border and basal area alone being slightly suffused with lilacine-grey; in the absence of markings across the centre of these wings, and in the inner line being replaced by a slightly inarched abbreviated blackbrown transverse stripe with whitish internal edge; secondaries almost exactly as in $R$. archesia; on the under surface it differs from the latter in its sandy yellow instead of reddish ochreous colour, in the reduction of the markings on the primaries, and the almost total obliteration of those on the secondaries. Expanse of wings, $42 \mathrm{~mm}$.

\section{Viti Islands.}

But for the well-defined blackish bar at the basal third of the primaries I should have thought it possible that this might be the female of $R$. mayeri.

\section{THERMESIID正.}

Erosia, Guenée.

57. Erosia stolida, n. s.

Allied to $E$. theclata of Africa and Ceylon (female of Dirades binotata); differs from both sexes of that species in its superior size, considerably paler, silvery greyish coloration; the markings white-edged, but not enclosed by an outer brown line; the outer margin of the primaries in the female more irregular than in $E$. theclata. Expanse of wings, $22-23 \mathrm{~mm}$.

\section{Rockhampton.}

The genus Erosia has hitherto been placed among the Geometrites, but it has been shown that its true position is amongst the Pseudo-Deltoids; the genus Dirades has hitherto been regarded as distinct, but it is now evident that it is founded upon the males of certain species of Erosia, the sexes of which differ in outline of wings. 


\section{HERMINIID \&.}

Bocana, Walk.

\section{Bocana sypnoides, n. s.}

q. Aspect of many species of Sypna; primaries purplish brown, almost black; an ill-defined dentated black line across the basal fourth ; reniform spot angular, golden testaceous, enclosing a black litura; two parallel widely sinuated and dentated externally pale-edged black discal lines, the external dentations dotted with whitish at their apices; a black marginal line dotted with pale ochreous; fringe blackish, varied along its outer edge with whitish; secondaries smoky brown; two internally diffused blackish stripes from abdominal margin, not reaching the costa, dentated and partly edged with whitish externally; a marginal series of pale ochreous dots; fringe spotted at the base with blackish; thorax dark purplish brown, the head and collar blackish ; abdomen dark smoky brown, slightly paler at the sides and base; wings below smoky brown, crossed by two darker diffused discal stripes, the outer one with pale external border; a sprinkling of whitish scales on the costal areas; a slender blackish marginal line, interrupted at the extremities of the veins by testaceous dots; secondaries with a blackish disco-cellular litura; palpi dark brown, the scales on the inner surface tipped with ochreous; body below smoky brown, the legs dark brown, with ochreous spots at the extremities of the joints. Expanse of wings, $42 \mathrm{~mm}$.

Viti Islands. Fiji.

Allied to B. manifestalis, which ranges from Ceylon to

LoPHOCOLEUS, n. g.

Form and neuration almost exactly as in Edessena, from which genus it is, however, at once distinguished by the long tapering broadly pectinated antennæ, in which character it agrees with Bocana; from the latter it differs in form of wing, and from both genera in the broad flattened and coarsely scaled palpi and the structure of the front legs, the femora being armed at their distal extremity by a strong curved process thicker than the tibia, and extending almost to the extremity of the tarsus, its lower surface clothed with long silky hairs; thus, at first sight, the leg appears to be double from the knee-joint.

\section{Lophocoleus mirabilis, n.s.}

ð. Primaries above dark smoky brown; the two ordinary lines indistinct, that at basal third represented by an unequally 
trisinuated dusky line from subcostal vein to inner margin; that at external third by a transverse series of greyish lunules with dusky inner edges (this series is inangulated or elbowed at the first median branch); a small whitish spot at the end of the cell, and a series of squamose whitish dots parallel to the outer margin; a series of minute whitish marginal points; outer margin rather acute and subfalcate at apex, and subangulated at the extremity of the second median branch; secondaries paler than the primaries, especially towards costa; fringe with an interrupted whitish basal line; thorax dark smoky brown, black-speckled; abdomen a little paler than the thorax; under surface greyish brown; primaries with grey internal border; secondaries with a dusky disco-cellular lunule and a diffused sinuous discal stripe; anterior legs armed with a strong curved process, clothed below with long silky stramineous hair. Expanse of wings, $47 \mathrm{~mm}$.

Viti Islands.

\section{Lophocoleus? astrifer, n. s.}

. Much like Bocana manifestalis in colour and pattern, but with the form of the preceding species; upper surface dark purplish brown, primaries with the two ordinary dentate-sinuate black lines; a sinuous discal series of black-edged cream-coloured dots, terminating in a spot of this colour at inner margin; fringe with a whitish basal line; secondaries crossed in the middle by a single black line; a discal series of black-edged cream-coloured dots, confluent towards the abdominal margin; fringe with a whitish basal line; head and thorax dark chocolate-brown, abdomen paler, purplish brown; wings below pale brownish, densely irrorated with blackish scales; costal areas washed with lilacine; all the wings with two black discoidal spots; a black irregularly dentated line beyond the middle; an imperfect dark brown discal band enclosing a series of pale spots; a slender wavy creamcoloured line at the base of the fringe; primaries with a subapical greenish grey patch; secondaries with an apical patch of the same colour; body below greyish, legs purplish brown. Expanse of wings, $38 \mathrm{~mm}$.

\section{Viti Islands.}

From the form of the wings this species appears to be a Lophocoleus, but unfortunately the palpi and anterior legs of the type are missing. 


\section{Matæomera, n. g.}

Somowhat allied to Rivula; primaries with the costal margin nearly straight, slightly incurved in the middle; outer margin straight to lower radial vein, then gradually arched to external angle; inner margin nearly straight, excepting at base, where it curves inwards; secondaries rather small, subpyriform, the costal margin nearly straight; costal vein of primaries extending to about the apical third of costa, subcostal five-branched, emitting its first branch before the end of the cell, second at some distance beyond the cell, third and fourth branches forking to apex, fifth emitted from the anterior angle of the cell ; radials emitted from the discocellulars near the anterior and posterior angles of the cell, second and third median branches and lower radial about equidistant at their origins; a small flattened tuft of hair from behind the base of the median vein directed forward over the base of the cell; subcostal of secondaries forking from the anterior angle of the cell; upper disco-cellular long, arched; lower disco-cellular very short and transverse, the radial and the second and third median branches being emitted near together and at equal distances apart; body very robust, palpi of male moderately long, triangular, compressed, coarsely scaled, rather obtuse at apex; palpi of female considerably longer and decidedly more acuminate; antennæ of male delicately ciliated to the tip, of the female somewhat flattened, submoniliform, and simple; legs with the femora grooved, the tibix flattened, fringed with long hair-scales in the male.

\section{Matcomera dubia, n. s.}

Primaries pale reddish brown; central belt represented by two arched white lines; the costa speckled with slaty grey up to the second line; a white-dotted black spot at the end of the cell, followed by slaty grey scales (in continuation of the costal irroration) as far as the second white line; costal margin from the central belt almost to the apex ochreous, the subcostal area whitish; a submarginal series of black spots white-bordered internally and confluent towards apex; an apical white point; fringe cupreous-red towards apex; secondaries whity brown, becoming bronze-brown towards anal angle; thorax ash-grey, white in front; head and abdomen whity brown; antennæ yellowish; under surface sericeouswhite, costal areas of the wings speckled with pale brown; fringe of primaries red-brown towards apex; legs pearl-white. Expanse of wings, $18 \mathrm{~mm}$.

\section{Peak Downs and Gayndah.}




\section{EUlocastra, n.g.}

Nearest to Locastra, of the same general form, though with the aspect of the Lithosiid genus Eutane; primaries with the costal vein extending nearly to apex; subcostal with five branches, the first branch emitted before the end of the cell, the second emitted beyond the cell, united to the third by a short cross vein so as to form a narrow post-discoidal cell, the third and fourth forming a short fork to apex, the fifth emitted from the inferior margin of the third at the extremity of the post-discoidal cell; upper radial emitted near to the anterior angle of the cell, lower radial forming a fourth median branch (the lower disco-cellular being absent) emitted from the posterior angle of the cell and equidistant with the second and third median branches; base of the wings below clothed with long hair-scales; secondaries with the costal and subcostal veins coalescing towards the base, the two subcostal branches emitted at about the middle of the wing; discoidal cell open, the upper disco-cellular veinlet being absent; radial emitted rather near to the posterior angle of the cell; second and third median branches emitted from one point at the posterior angle; body rather robust, the thorax rounded, the head twice as broad as long; antennæ cylindrical, tapering, with very short fine ciliations ; palpi long, thick, subcylindrical, slightly compressed, upcurved; legs rather long and thick, the middle tibiæ fringed with rather long hair-scales.

\section{Eulocastra fasciata, n. s.}

ð. Primaries above shining silvery white; the base, an irregular transverse band just before the middle, a second from costa near apex to external angle, a spot just above the middle of external border, and a second at external angle, black with bronzebrown reflections; secondaries sericeous-stramineous, with a brownish apical spot; thorax bronze-brown, collar cupreous; tegulæ clothed with metallic cupreous and blue scales; head and abdomen pale stramineous; under surface pale shining golden stramineous, primaries with the discoidal area, a discal band as above, but enclosing three subcostal dots of the ground colour and a few scales on the fringe blackish; secondaries with an abbreviated squamose dash from the centre of costal margin to the end of cell and a slightly longer tapering subapical dash blackish; legs barred with black. Expanse of wings, $20 \mathrm{~mm}$.

Sydney.

Although this species in general appearance, and in 
the supplementary cell in the neuration of its primaries, corresponds with the Lithosiida, it differs entirely in its very characteristic palpi : a comparison of its structure with that of Locastra shows it to be evidently allied to that genus.

\section{SICULID正. \\ Microsca, Butler.}

\section{Microsca plagifera, n. s.}

Fiery cupreous, indistinctly speckled and striated with earthy greyish; primaries with an unequally subquadrate silver patch, through the centre of which runs a golden reticulated bar; wings below paler than above, sericeous-red, reticulated with dark grey; primaries with the basi-costal area and the centre of disc earthy greyish; patch of upper surface pearly, corrugated, the reticulated band dark ochraceous; body below testaceous; anterior legs brownish, with testaceous bands. Expanse of wings, $25 \mathrm{~mm}$.

\section{Tonga Island.}

Somewhat resembles Felder's Thermesia? fenestrina, which probably is not a Thermesia.

\section{Pharambara, Walk.}

\section{Pharambara reticulata, n.s.}

o. Not unlike the female of P. micacealis; golden testaceous, slightly rosy towards outer margins; with numerous darker reticulations which tend to form lines in some instances, only one of these lines, however, is at all pronounced, forming a slightly sinuous submarginal line across the primaries; a slender marginal black line along the costa, interrupted by seven or eight minute black-edged yellowish spots; a series of extremely minute black points near outer margin, the third from costa continued obliquely downwards as a slender abbreviated zigzag line; fringes tipped with whitish; under surface pale shining testaceous, with the body and internal areas of the wings almost cream-coloured, but the apical areas washed with reddish golden; reticulations more strongly defined than above, golden cupreous, some of them expanded into angulated stripes enclosing black dots and striæ; three of these stripes cross the primaries, the central one united to a patch of the same colour, dotted with black and silver at the end of the cell ; the base of the cell, costal vein, and median vein are also defined by metallic silvery and opaline scales; an oblique subapical black line; legs clay-coloured or reddish ochraceous; 
posterior tarsi banded with silvery whitish. Expanse of wings, $20 \mathrm{~mm}$.

Peak Downs.

\section{ENNYCHIIDE. \\ GrapHICOPODA, n. g.}

Seems to come nearest to Ennychia, the wings of the same form; costal vein of primaries terminating at about second third of the margin; subcostal five-branched, the first branch emitted before the end of the cell, the second, third, and fourth form a long footstalk, the second and third running to costa near apex and the fourth to apex, the fifth emitted from the inferior margin of the same footstalk just beyond the cell ; radials emitted from opposite angles of the cell, the disco-cellular being obsolete; secondaries with the costal vein thickened towards the base; forked at some distance beyond the cell, the subcostal simple, free, tapering to a fine point below the costal vein but not passing into it, met by an arched line of colour, which probably indicates the former existence of a disco-cellular (or transverse) vein, now obsolete; radial forming a fourth median branch; body tolerably slender, extending only a short distance beyond the secondaries; antennæe with large and somewhat cuneiform basal joint, otherwise thick, especially towards the middle, sparsely and delicately pilose; palpi straight, thick, rather long, porrect, coarsely scaled, the terminal joint rather short and acute; legs rather long, compressed, the femora longitudinally deeply grooved, anterior femora with a thick tuft of hair towards the distal extremity, which curls forwards over the knees and projects from the inner surface; anterior tibix short, bearing a pencil of hairs, which is emitted below the knee and lies flat below the joint; tarsi long; second pair of tibix bearing a terminal spur, as long as the first tarsal joint, and a long smooth pencil of gradually expanded hair-scales, which almost conceals the spur when viewed from the side; the distal extremity of the tibial joint is also oblique and fringed; tibiæ of last pair of legs bearing the usual two pairs of unequal spurs.

\section{Graphicopoda hecate, n.s.}

Wings above pitchy black-brown; the primaries with two illdefined basal spots and a third spot below the origin of the first median branch of grey, changing in certain lights to opaline-lilac; secondaries with the basi-costal area whitish; body above greyish brown; wings below blackish piceous, with the basal third whity brown, showing two blackish lunate spots towards the extremities 
of the discoidal areas; interno-basal area of primaries greenish opaline in certain lights; body below and legs sordid whitish or pale whity brown. Expanse of wings, $21 \mathrm{~mm}$.

Tonga Island (Friendly Islands).

\section{HYDROCAMPID庄.}

\section{Pseudephyra, n. g.}

Apparently nearest to Homophysa, though the palpi differ considerably; wings broad, having the general aspect of the Geometrid genus Ephyra, especially of $E$. splendens: very like Homophysa in neuration; body very robust, not extending beyond the secondaries; palpi porrected, large, compressed, expanded in front by a long fringe along the anterior surface, the terminal joint small and directed slightly downwards so that the anterior, or more strictly speaking, inferior, margin of the palpus is elongate sigmoidal; antennæ filiform, extending to beyond the middle of the wing; legs moderately long, stout, and somewhat compressed.

\section{Pseudephyra straminea, n. s.}

Bright straw-yellow; primaries with a subbasal reddish ochreous band, bounded by a metallic leaden line and sprinkled with metallic scales; reniform spot indicated by two plumbageous dots connected by short ochreous lines; an angulated black-bordered reddish ochreous discal band, bounded internally by a plumbageous line of scales; external margin irregularly bordered with reddish ochreous; secondaries with a dot at the end of the cell, and the external two-fifths reddish ochreous, the latter crossed by a discal band similar to that on the primaries; a line of plumbageous scales close to outer margin; abdomen reddish ochreous crossed by slender black lines; under surface pale stramineous; the wings crossed by arched discal blackish bands, which do not reach the margins. Expanse of wings, $19 \mathrm{~mm}$.

Var. The reddish ochreous spots and bands replaced by black spots and broader greyish brown bands mottled with black; the plumbageous scales remaining. Expanse of wings, $18 \mathrm{~mm}$.

Peak Downs.

\section{Niphadaza, n. g.}

Apparently nearest to Oligostigma; wings narrow, elongated, acute at apex; primaries with the outer margin very oblique; costal margin nearly straight, costal vein extending to about the apical third of costa; subcostal five-branched, emitting its first two branches before the end of the cell, its third just before the 
apex, its fourth running to the apex, fifth branch emitted from near the base of the long footstalk, which bears the third and fourth branches, just beyond the cell; upper radial vein emitted from the anterior angle, and lower radial from the posterior angle of the cell; disco-cellular veinlet angulated; the three median branches well separated from each other at their origins; secondaries with the costal margin nearly straight, outer margin slightly arched, abdominal margin short and nearly straight; costal and subcostal veins contiguous to basal fourth, where they coalesce, but separate again just before the middle of the wing, the costal vein forming a long furca to apex and the subcostal continuing straight on to the outer margin; disco-cellular veinlet absent, the cell consequently open, and the radial emitted as a fourth median branch; palpi moderately long, directed forwards so as to show almost their entire length in front of the head; antennæ short, slender, moniliform, finely penicillated; thorax robust, projecting well in front of the wings; tegulæ large, extending to beyond the mesothorax; legs thick (both legs and abdomen broken short off in the type).

\section{Niphadaza bicolor, n. s.}

Primaries above rust-red; the base, an externally angulated band across the basal third, a small spot near the base of the lower radial interspace, a large apical costal spot, separated by a curved stripe of the ground colour from an internally somewhat conical external border (the centre of which is divided again by a forked line of the ground colour) snow-white; secondaries snow-white, with a large subbasal interno-median spot, a broad discal band with arched outer edge and a small oblique spot near the middle of the outer margin, rust-red; antennæ dark ferruginous banded with white; body snow-white, collar with a ferruginous spot on each side, thorax with darker red-brown scales at the sides; primaries below pale golden, with white markings almost as above; secondaries white, with a narrow diffused golden discal streak; body white. Expanse of wings, $24 \mathrm{~mm}$.

Viti Islands.

\section{Oligostigma, Guenée. \\ 68. Oligostigma pallida, n. s.}

Chalky white; primaries sparsely irrorated with dark brown scales to external third, crossed at basal two-sevenths by an elbowed pale ochreous band; a second widely bisinuated ochreous band crossing the wing obliquely beyond the middle; a third band, twice interrupted and with dusky zigzag external edge near to outer 
margin; a submarginal series of short black dashes followed by a narrow testaceous stripe, and a marginal series of black dots; fringe slightly testaceous; an oblique blackish dash upon the first ochreous band just below the median vein, and an imperfect annular blackish spot at the end of the cell; secondaries crossed near the base by an oblique blackish-speckled pale ochreous line; a second line crossing the middle of the wing from abdominal margin to costa, emitting a branch inwards from the end of the cell to the costa nearer the base; a dusky-edged pale ochreous band crossing the disc, attenuated and elbowed towards the costa; an undulated submarginal blackish line followed by a testaceous line and a marginal series of black dots; fringe tinted with testaceous; markings below, excepting along the outer margins, very indistinct. Expanse of wings, $23 \mathrm{~mm}$.

Rockhampton.

\section{ASOPIID正. \\ Rinecera, Butler. \\ 69. Rinecera nigrescens, n. s.}

Allied to $R$. mirabilis; purplish black; primaries crossed at basal fourth by an irregularly angulated whitish line; a second very indistinct and very irregular zigzag line from costa to first median branch, along which it runs inwards for some distance, and then turns abruptly at a right angle and passes with two alternate angles to inner margin; discoidal spots represented by two little white dashes ; secondaries crossed by two whitish lines, the first interrupted by a white dot at the end of the cell, the second running from about the middle of the outer margin to the costa; both lines ill-defined in the male; wings below nearly as above, but the internal borders sericeous-whitish; body below sordid white. Expanse of wings : male, $23 \mathrm{~mm}$. ; female, $20 \mathrm{~mm}$.

Viti Islands.

The species is larger and darker than R. mirabilis, and differs in many details of colouring; both evidently differ structurally from Ceratoclasis barbicornis, Feld.

\section{Hormatholepis, n. g.}

Allied to Rinecera; wings elongated; primaries with the costa deeply grooved below to a little before the middle, where the costal vein bends somewhat inwards before its termination; subcostal vein apparently five-branched; * remaining veins as in Niphadaza;

* Owing to the folding over of the costal border in the type these branches are difficult to follow, but they appear to be similar 
a thick tuft of projecting hair emitted from the middle of the internal border on the under surface of the primaries; body much elongated, antennæ much elongated, extending to about the fourth fifth of costa of primaries, the basal joint large, cylindrical; following joints short, somewhat flattened, tapering, knotted above the middle, and emitting a tuft of long clubbed scales, which project forwards and slightly upwards to the distal fourth; palpi long, curved, porrected; second joint bearing a long pencil of hairs above and a shorter one below the terminal joint (giving the appearance of three pairs of palpi from one base; legs long and rather slender, femora grooved; anterior and middle tibiæ short, with an appressed terminally fringed spur emitted from its inferior margin and running forwards to the extremity of the joint; posterior tibiæ with three long slender spurs, the first projecting from near the middle, and the two others from the distal extremity of the joint.

\section{Hormatholepis erebina, n. s.}

Dark smoky grey, with slight purplish and bronze reflections, the primaries almost crossed by two irregular blackish bands, the first across the basal third, and the second just beyond the middle; both of these bands have zigzag external edges; wings below darker than above. Expanse of wings, $28 \mathrm{~mm}$.

Viti Islands.

\section{Asopia, Guenée.}

\section{Asopia leonina, n. s.}

Primaries above bright straw-yellow, with purple-glossed black markings, almost exactly as in Dichocrocis frenatalis of Lederer, as follows: an arched line across the base; a bisinuated line, angulated upon the median vein before the middle; an oblique reniform spot, enclosing two whitish dots, at the end of the cell; a sinuous line across the disc, bending inwards so as to touch the posterior extremity of the reniform spet, and a marginai line, emitting a streak above its centre to join the discal line, and broken up into spots towards external angle; fringe whitish, spotted with grey; secondaries distinctly paler, cream-coloured shot with stramineous, the dise crossed by an abbreviated and slightly tapering grey stripe; an external grey border confined to apex and a continuous black marginal line; fringe spotted with blackish; front of thorax and centre of abdomen bright straw-yellow; the latter with dorsal blackish dots; remainder of body above shining

to those of Niphadaza (Hydrocampida): the wings are delicate, and will not bear much damping with benzine. 
cream-colour; anal segment tipped and spotted with grey; wings below cream-coloured, sericeous, with stramineous reflections; markings on primaries less strongly defined than above; fringe whitish, spotted with grey; body below sericeous, cream-coloured. Expanse of wings, $17 \mathrm{~mm}$.

\section{Peak Downs.}

\section{LEUCOPHOTIS, n. g.}

Allied to Agathodes (A. ostentalis); with similar neuration; style of coloration of Leucinodes; body very robust, palpi erect, one-third of their length being visible above the top of the head, compressed, but not so broad as in Agathodes, and with prominent terminal joint; antennæ extending to about second third of primaries, serrated and finely penicillated along their inner or anterior surface; tegulæ large, expanded, almost entirely covering the thorax, abdomen extending about half its length beyond the secondaries, dorsally keeled and tufted, and with five tufts on each side; wings broad, as in Margarodes.

\section{Leucophotis pulchra, n. s.}

Wings semitransparent, yellowish; basi-internal area of primaries above clay-coloured, crossed by two subbasal dull blackish bars, shot with steel-blue; a third oblique interrupted blackish bar running from the middle of the inner margin to the end of the cell; discoidal spots near together, annular, ferruginous, with yellowish centres; an irregular subapical blue-black patch, edged internally by a slender white line, but externally bounded by a diffused ferruginous border; an indistinct undulated ferruginous and ochreous submarginal line curving inwards towards costa; secondaries with a rather broad abbreviated oblique band of blueblack, with ferruginous edges, from the middle of the radial interspace across the end of the cell to the submedian vein, up which it runs almost to the base, a subbasal brown spot; an angular subapical blue-glossed blackish patch bordered externally with reddish ochraceous, and partly confluent with an irregularly sinuated ochreous submarginal line; head above yellow, banded with ferruginons ; antennæ ferruginous ; collar reddish testaceous; tegulæ pale greyish brown, opaline in certain lights; abdomen greyish brown, reddish at the base ; lateral tufts with a plumbageous gloss; under surface sericeous cream-colour; the dises of the wings semitransparent; an abbreviated transverse black bar from the cell almost to the inner margin in all the wings, and the subapical angulated black patches of the upper surface; front pair of legs 
blackish above; venter with a central longitudinal clay-coloured line. Expanse of wings, $49 \mathrm{~mm}$.

Viti Islands.

This is one of the largest, and at the same time strikingly coloured, of the Pyrales.

\section{Endotricha, Zell.}

\section{Endotricha annuligera, n. s.}

General appearance of Locastra (L. amica and allies); primaries greyish brown, with the central third creamy, subhyaline, bounded by the usual lines, which are black; the outer line broken up into spots and of the usual angulated form; four black annular costal markings upon the central area ; a small cuneiform costal creamcoloured spot beyond the outer line, in continuation of the central belt; reniform spot represented by a curved clavate brownish outline; fringe micaceous-grey, with a basal black-spotted creamcoloured line; secondaries cream-coloured, with the external third irregularly grey-brown; fringe as in the primaries; head and front of thorax brown, mottled with whitish and pale testaceous; back of thorax white; abdomen white, with a large slightly greyish scutiform central patch, partly margined and dotted with black-brown; primaries with markings as above, but the black lines on the primaries replaced by grey, and the basal area creamcoloured; body below creamy white. Expanse of wings, $17 \mathrm{~mm}$.

\section{Peak Downs.}

Though much unlike the known species of Endotricha in coloration, this species appears to belong to that genus.

\section{Endotricha obscura, n. s.}

q. Nearest to E. docilisalis; considerably smaller, with differently coloured fringes and differently formed lines across the secondaries on the under surface; upper surface shining dark lilacine-grey, costa of primaries golden brown, with a very slender black edge dotted with yellow; a faintly indicated arched line across the basal third; a slender slaty grey submarginal line, internally white-edged at costa; fringe bright golden chromeyellow tipped with silvery white, replaced by shining cupreous tipped with lilacine at apex, in the middle and at external angle, the two latter patches of deeper colour being moreover connected by a partly confluent series of plum-coloured dots near the base of the fringe; secondaries with pearl-white costal area; faint irdications 
of two grey-edged pale lines across the wings; fringe silvery white, golden cupreous, spotted with plum-coloured lunules at the base; head, collar, and tegulæ golden brown; thorax and abdomen lilacine greyish; primaries below smoky grey, shot with lilacine; internal area white; costal margin black, spotted with yellowish; costal area golden towards apex; a biangulated white line towards outer margin, its costal third black-edged externally; a black marginal line; fringe nearly as above; secondaries rosy lilacine, whitish on the basi-abdominal area; an angulated grey-brown stripe at basal third, and a lunule of the same colour at the end of the cell; a broad tapering brown stripe enclosing a pink undulated line from costa to anal angle; a partly confluent marginal series of black dashes; fringe almost as above; body below dull rosecoloured, legs partly white, tarsi more or less broadly banded with grey-brown; anal segments golden ochreous in the centre. Expanse of wings, $21 \mathrm{~mm}$.

Rockhampton.

The allied $E$. docilisalis has been declared to be synonymous with $E$. stilbealis, a species differing from it in size, coloration, and pattern; the two have also been pronounced to be females of Messatis sabirusalis = Paconia albifimbrialis = Tricomia auroralis $=$ Rhodaria robina; if it be a fact that either $E$. docilisalis or $E$. stilbealis is the female of Walker's M. sabirusalis (which has much the aspect of Rhodaria sanguinalis on a larger scale), the species can no longer remain in Endotricha, a genus in which the sexes agree in both size, form, and pattern.

$E$. obscura, in pattern, nearly resembles $E$. sondaicalis of Snellen from the Celebes.

\section{Rhimphalea, Led.}

75. Rhimphalea anone, n. s.

Pearly semitransparent white, wings with a broad internally dentated bronze-brown border with purplish reflections, enclosing three acute closely approximated spots above the median branches; veins black; wings crossed beyond the middle by a very irregular purplish brown line parallel to the inner edge of the external border; primaries with the costal border creamy white; two or three blackish subbasal spots; two irregular lines crossing the wing, the first near the base, the second (partly formed by a large purplish black reniform spot) across the middle; orbicular spot 
somewhat elongated, angulated in front; a longitudinal black streak almost uniting the two lines below the cell; fringes of all the wings plumbageous-grey, with a whitish basal and a black subbasal line; head and front of collar pale ochreous; back of collar pale sericeous-grey; a large black spot on each tegula; abdomen pearly white; wings below as above; body pearl-white, front legs greyish. Expanse of wings, $25 \mathrm{~mm}$.

Rockhampton.

\section{Pterygisus, n. g, ; Isopteryx, Guenée.* 76. Pterygisus ochreipennis, n. s.}

Primaries black, changing in certain lights to dark chocolate; an ochreous spot at base of inner margin; a paler ochreous band from the median vein to the inner margin at basal fourth; a minute spot of the same colour obliquely above the latter within the cell; two white spots placed transversely in the middle of the wing; a small pale ochreous spot obliquely below the latter close to inner margin; a quadrate white spot immediately beyond the cell; an ochreous subapical costal spot; three small ochreous discal spots on the median interspaces, forming a transverse tapering line; fringe alternately black and white ; secondaries deep ochreous; the centre of the costal border, a tapering abbreviated, -shaped streak just before the middle, an angulated discal line and the outer border (sinuated in the middle), black; thorax brown; abdomen grey, pale testaceous at the base. Expanse of wings, $18 \mathrm{~mm}$.

\section{Peak Downs.}

\section{Gonocausta, Led.}

\section{Gonocausta? asuridia, n. s.}

Like the small genus Asura (Lithosiida) in coloration; primaries above with two ochreous spots towards the base of the costa, an oblique cream-coloured streak from the second of these spots almost to the inner margin; and two broad cream-coloured bands, central and discal, connected near the centre so as to form the letter [x], thus; fringe whitish, with the middle, the apex, and the external angle, black; secondaries ochreous, streaked with black at the base; the outer half of the costal border, a broad apical patch, a smaller anal patch, and a narrow external border uniting all together, black ; fringe alternately black and white; body dark chocolate-brown; the head and back of tegulæ pale ochraceous;

* Preoccupied in Neuroptera (Pictet, Hist. Nat. Neur. Perlides). TRANS. ENT. SOC. LOND. 1886.-PAR'I IV. (DEC.' $2 \mathrm{G}$ 
abdomen crossed by slender white segmental lines; under surface nearly as above; palpi ochreous, legs and venter banded with ochreous. Expanse of wings, $20 \mathrm{~mm}$.

\section{Peak Downs.}

\section{MARGARONIIDÆ.}

78. Margaronia limbata, n. s.

Allied to $M$. transvisalis ; primaries silvery white; costal border golden ochraceous; veins towards outer margin greyish, in certain lights cupreous; fringe, excepting at apex, grey with bronze reflections and whity brown basal line; secondaries pearly white, with diffused grey external border and slender dusky marginal line; fringe white, the apical half tipped with grey; body silvery white; antennæ pale bronze-brown; primaries below white to the end of the cell, with the veins and costa greyish; remainder of the wing sericeous-greyish; secondaries sericeous snow-white, with greyish external border; body below silvery white; an ochreous lateral stripe running from the tip of the palpus to the shoulder. Expanse of wings, $27 \mathrm{~mm}$.

Rockhampton.

The greyish border to the secondaries in this species is sufficient to distinguish it at a glance from $M$. transvisalis, apart from other characters.

\section{BOTYDID王.}

Botys, Latr.

79. Botys horatius, n. s.

Nearly resembles $B$. hecalialis of St. Domingo, excepting in its inferior size; bright golden ochreous; primaries with the central area slightly opaline; an oblique purplish black dash at base of costa ; a subangulated purplish black line across the basal fourth; a short transverse line at the end of the cell and a line across the external fourth arched from costal margin to first median branch, and thence biangulated or zigzag to inner margin; secondaries pale towards the costa; a slightly irregular purplish brown line from the end of the cell to the anal angle; markings below less strongly defined than above. Expanse of wings, $20 \mathrm{~mm}$.

Viti Islands.

This species is also probably allied to Astura? clytusalis, Walk. (Botys clytialis, Led.). 


\section{Botys argyrogaster, n. s.}

Pale golden testaceous; wings becoming gradually pearl-white towards the base; orbicular spot represented by a golden brown dot; reniform spot by a little transverse spot of the same colour; a faint indication of a golden brown wavy discal line; back of thorax pearl-white, abdomen golden testaceous, becoming darker towards the posterior margins of the segments, which are pearlwhite, sides and anal segment pearl-white; wings below slightly paler than above, pectus white, legs cream-coloured; venter silvery white. Expanse of wings, $25 \mathrm{~mm}$.

\section{Viti Islands.}

Belongs to the long-winged group of this too elastic genus.

\section{EMPREPES, Led.}

\section{Emprepes insignis, n. s.}

Primaries above rather pale chrome-yellow, with broad internally bisinuated shining bronze-brown outer border; a small spot of yellow, with a faint submarginal streak of the same colour above it, near external angle; costal margin to just beyond the end of the cell, a subbasal transverse stripe and a quadrate spot at the end of the cell (uniting the costa to the angle between the sinuations of the external border) black-brown; secondaries shining bronze-brown; costal area white, excepting at apex; fringe greyish; head above cream-colour; collar dark brown, with a cream-coloured spot on each side; thorax ochreous, with a dark brown band across the front; abdomen pale bronze-brown, with whitish hind margins to the posterior segments; under surface with the brown areas more golden; otherwise much as above. Expanse of wings, 17-18 $\mathrm{mm}$.

Male, Gayndah; female, Peak Downs.

\section{Scopula, Schr.}

\section{Scopula auritincta, n. s.}

Golden ochraceous, primaries paler towards the inner margin; base of the wing crossed by a broad imperfect greyish brown 8-shaped figure, not reaching the margins; a quadrate spot closing the cell, and a second large oblique 8-shaped figure (open at its extremities) crossing the disc; this figure is formed by an angulated discal stripe united just about its central angle to a 3 -shaped submarginal stripe; neither of these stripes extend to the costal or 
inner margins; secondaries considerably paler than the primaries, excepting along the outer margin; an indistinct greyish apical border; wings below uniform pale golden stramineous, the primaries showing traces of the markings of the upper surface; pectus silvery white, legs partly ochraceous; venter creamcoloured, with glistening white hind margins to the segments. Expanse of wings, $25 \mathrm{~mm}$.

Peak Downs.

\section{Nymphula, Schr. \\ 83. Nymphula sordida, n.s.}

Whity brown, with faint golden reflections; primaries with a small dusky spot at the base; a dark brown dot just below the middle of the discoidal cell; orbicular spot also represented by a similar dot; reniform spot well-defined, smoky brown; a diffused smoky brown apical spot and a streak of scattered scales of the same colour near outer margin ; a marginal series of blackish dots; fringe shining whitish, traversed by a dusky line; secondaries slightly greyish, with darker diffused external border; fringes as in primaries; thorax greyish; wings below whity brown, slightly pearly; markings obsolete; body below pearly white. Expanse of wings, $24 \mathrm{~mm}$.

Rockhampton.

BOARMIIDE.

BoARmia, Treit.

\section{Boarmia tongaica, n. s.}

Yellowish (or bone-) whitish; external borders of the wings blotched with sepia-brown, crossed by a submarginal dentatesinuate white line; an angular undulated sepia-brown discal band, traversed along its inner edge by a line of the ground eolour; a conspicuous black spot enclosing a line of silvery grey scales at the extremity of each discoidal cell, below and beyond which spot is a dusky nebulous patch, widest on the secondaries; an irregular oblique dark brown line commencing with an elbow at the middle of the costal margin of the primaries, passing in front of the cell in these wings and behind the discoidal spot on the secondaries, terminating at about the middle of the abdominal margin; base mottled with blackish brown; primaries with an elbowed blackedged brown band across the basal fourth; costal margin irregularly spotted with black; thorax greyish brown; tegulæ and abdomen spotted with black; under surface of the wings with the disc clouded with greyish brown; a spot of the ground colour at the apices of the wings, a second at the extremity of the second 
median interspaces, and a diffused discal streak from the inner margins near the posterior angles; the anal border of secondaries also whitish; discoidal spots well-defined, black in the centre; markings towards the base ill-defined; body below bone-whitish. Expanse of wings, $42 \mathrm{~mm}$.

Tonga Island.

Not very nearly allied to any known species.

\section{Boarmia samoana, n. s.}

Pale vinous-brown, irrorated with sepia-brown; wings crossed by blurred imperfect sepia-brown lines and spots, as in $B$. abietaria of Europe; an undulated yellowish testaceous undulated discal stripe, interrupted by the dark brown spots, which succeed the outer line of the central band, the primaries also with two longitudinal divergent stripes of the same yellowish colour below the cell, and one or two indistinct yellowish spots towards base of costal border; abdomen with the usual dorsal series of black dots in pairs; under surface with the markings almost obliterated, the annular discoidal markings represented by a large grey spot on the primaries and a smaller one on the secondaries; a greyish diffused submarginal band widening into a broad patch towards costa of primaries; the costal border of these wings also spotted with blackish. Expanse of wings, $36 \mathrm{~mm}$.

\section{Samoan Islands.}

Nearest to $B$. procursaria from India.

\section{Boarmia godeffroyi, n. s.}

Apparently most nearly allied to $B$. secundaria of Europe; whity brown; most of the lines across the wings externally illdefined, only indicated here and there by a few dark brown scales; spots at the extremities of the discoidal cells large, blackish, enclosing a white crescent; the post-median blackish line and the undulated brown stripe beyond it distinct, excepting on the median interspaces of the primaries and the costal area of the secondaries; the costal area of the primaries clouded with greyish towards apex; a marginal series of black dots; secondaries with the central belt rufous-brown from the disco-cellular spot to the abdominal margin; abdomen with the usual black dots; wings below whiter than above, with the disc purplish grey, forming a broad belt across the wings, with its centre rather paler than its borders, that on the primaries extending to the outer margin, excepting at apex and 
extremity of second median interspace, that of the secondaries zigzag and partly touching the outer margin towards apex; discocellular spots represented by large black spots. Expanse of wings, $35 \mathrm{~mm}$.

\section{Rockhampton.}

The coloration of this species is decidedly peculiar, especially on the under surface, which is like that of Ophthalmodes.

\section{Ægitrichus, n. g.}

Allied to Boarmia; neuration very similar, especially in the primaries; the subcostal branches of the secondaries and the second and third median branches emitted at a short distance from each other instead of from the same point; the disco-cellular veinlet also much more deeply inarched than in Boarmia; on the under surface of the secondaries are two thick masses of woolly hair, the first projecting from the outer half of the median vein and the base of its first branch over the interno-median area, the second spreading outwards from the basal half of the abdominal margin; body robust, palpi rather longer than in Boarmia, porrected, with deflexed short fusiform terminal joint; antennæ wanting in the type.

\section{Agitrichus lanaris, n. s.}

Nearly resembles Boarmia consortaria, but the ground colour of the wings is whiter, the disco-cellular spots are well-defined, crescentshaped, white, that of the primaries with a grey border; the lines across the wings are also better-defined, blacker; the submarginal dark-bordered zigzag white stripe is farther from the outer margin, the lines of the central belt converge more towards the inner margin of the primaries, the outer line in all the wings is less regular, and the black dots along the outer margin are betterdefined; on the under surface the differences are considerably more marked, the ground colour both of wings and body being of a pale sericeous vinous-grey instead of clear cream-colour, and the markings consist of ill-defined greyish disco-cellular spots, an arched discal streak and a submarginal band, barely distinguishable on the primaries; the hairy masses are tipped with grey. Expanse of wings, $47 \mathrm{~mm}$.

Viti Islands. 


\title{
LyCAUGes, Butler.
}

88. Lycauges proxima, n. s.

Very near $L$. lactea of Japan, of nearly the same size and general tints; whity brown, almost white; wings with a black disco-cellular dot, an oblique greyish stripe beyond the cell, its upper extremity touching a slender black dotted grey discal zigzag line, elbowed towards costa; two undulated grey submarginal stripes, ill-defined on the primaries, and a marginal series of extremely minute black points; costal margin of primarie yellowish in certain lights; the submedian area of these wings on the under surface greyish; basal half of secondaries below sprinkled with grey scales; all the black dots of the upper surface present, but the grey stripes and lines ill-defined. Expanse of wings, $19 \mathrm{~mm}$.

\section{Rockhampton.}

This species should be placed between $I$. defamataria and $L$. lactea.

\section{GEOMETRID冉. \\ Chlorochroma, Dup. \\ 89. Chlorochroma neptunus, n. s.}

Dull sea-green; primaries crossed by two widely-separated slender undulated white lines; costal margin very narrowly edged with creamy whitish; a small dark green disco-cellular lunule; fringe whitish, with a central green stripe; secondaries crossed beyond the middle by a single slender subangulated undulated white line; a dark green disco-cellular dot; fringe as in primaries; vertex of head and upper surface of antennæ snow-white, under surface of antennæ cream-coloured; wings below, especially the secondaries, suffused with pearly white; costal margin of primaries cream-coloured; markings obsolete; body below white; legs yellowish. Expanse of wings, $26 \mathrm{~mm}$.

\section{Gayndah.}

Nearest to $C$. carenaria, which appears to have been described from worn examples of Geometra submissaria of Walker.

\author{
IDEIDE. \\ IDAAA, Hübn. \\ 90. Idca lydia, n.s.
}

Whity brown, irrorated with grey-brown; a slightly irregular smoky brown band crossing the primaries obliquely beyond the 
middle and the secondaries at the middle; a paler and more diffused band beyond the latter, its outer edge zigzag; secondaries also with a submarginal stripe of the same colour; an almost marginal series of black points alternately placed with a series of small brown spots at the base of the fringe; markings below less strongly defined. Expanse of wings, $23 \mathrm{~mm}$.

Peak Dorns.

\section{Allied to I. attributa.}

\section{Idaa jessica, n. s.}

Nearly allied to the preceding species, smaller, the primaries more acute; the band beyond the middle much nearer to the outer margin, narrower, paler, and less irregular; the discal band following it better-defined upon the primaries, and with undulated (not zigzag) external edge; a submarginal series of grey-brown spots on all the wings; dots at outer margin extremely minute; secondaries with a black dot at the end of the cell. Expanse of wings, $17 \mathrm{~mm}$.

\section{Peak Downs.}

\section{Id\&a nivipennis, $\mathrm{n} . \mathrm{s}$.}

Snow-white; wings crossed beyond the middle by two parallel slender grey dentated lines and two subconfluent squamose stripes near the outer margin; a marginal series of very minute blackish points; primaries with a very slenderly ochraceous costal margin; a minute black point at the inferior angle of the cell; face brown, darkest towards the vertex of the head, the latter white; front of collar orange; antennø brown, becoming white at the base; under surface snow-white; the costal margin of the primaries ochreous anterior coxæ yellowish; anterior tibiæ and tarsi brownish above. Expanse of wings, $26 \mathrm{~mm}$.

Viti Islands.

\section{Idra innocens, n. s.}

Belongs to the I. ornata group; small; chalky white, with small but conspicuous black disco-cellular spots; a very irregularly sinuous olive brownish line crossing the primaries in front of the disco-cellular spot, curving inwards below it and then downwards with a slight curve inwards to inner margin, crossing the secondaries obliquely behind the disco-cellular spot at about the basal third; a faint indication of a brownish discal line, followed 
by an internally diffused widely undulated brownish band towards outer margin; an imperfect submarginal brownish stripe, a marginal series of linear black markings almost forming a perfect marginal line; wings below only showing the black markings, the primaries also with an indication of the undulated brownish band; these wings are suffused with pale brown, excepting towards inner margin; legs brownish. Expanse of wings, $18 \mathrm{~mm}$.

Rockhampton.

\section{Id aea agnes, n. s.}

Pure white; primaries with a brown and secondaries with a black disco-cellular dot, from which to the inner margins is a faint linear stain of brown (only visible with a lens); a very slender crenulated brownish discal line, dotted with black, and externally edged with ochreous upon the radial interspaces of the primaries; two barely visible parallel brownish stripes; a marginal brown line dotted with black, and interrupted at the extremities of the veins on the secondaries; face dark brown; antennæ bronzebrownish; back of head pale ochreous; pectus silvery white; anterior and middle legs silvery brownish in front; abdomen chalky white; primaries below sericeous, sordid white, pure white towards inner margin; secondaries pure white; black dots as above; other markings obsolete. Expanse of wings, $22 \mathrm{~mm}$.

Rockhampton.

Allied to I. deliciosaria, and belongs to the group with angulated secondaries, flattened posterior tibiæ, and short posterior tarsi.

\section{FIDONIID必. \\ Panagra, Guenée.}

\section{Panagra rupicolor, n. s.}

Dove-grey, sparsely irrorated with dark grey; a black spot at the extremity of each discoidal cell, and an abbreviated blackbrown stripe from just beyond the middle of each inner margin, that on the primaries strongly marked, with pale inner edge, oblique, extending to the lower radial vein; a small spot at about the basal third of the submedian vein; the stripe on the secondaries slender, disappearing at the base of the second median branch; fringes pale brown; under surface paler, the primaries very pale bronzy brownish, indistinctly and transversely striated with grey; costal border and veins pale straw-yellow; a blackish disco-cellular spot; secondaries white speckled with dark grey, with three subapical spots and a subanal dash of the same colour; veins yellow; 
fringe yellowish at the base; a black disco-cellular spot; body whity brown. Expanse of wings, $33 \mathrm{~mm}$.

Peak Downs.

CAsBIA, Walk.

96. Casbia irrorata, n. s.

․ Pale pinky brown with golden reflections, densely irrorated with grey; wings with very minute marginal black dots ; primaries with the costal border slightly whitish; head dark brown; under surface white, grey-speckled, with a faint bronze-brown tint in certain lights; external borders pinky brown, mottled with grey; a small blackish disco-cellular spot on each wing; legs creamcoloured. Expanse of wings, $26 \mathrm{~mm}$.

Rockhampton.

Allied to C. rectaria, Walk., but without the bands and spots characteristic of that species; it seems improbable that it can be a variety.

\section{Aspillates. \\ 97. Aspilates clarissa, n. s.}

General aspect of very pale examples of Osteodes turbulentata, Guen. (=Aspilates exumbrata and semispurcata, Walk.), sericeous pinky whitish, indistinctly irrorated with grey-brown scales; under surface of a more creamy tint, with the costal border of the primaries slightly ochraceous; the female decidedly whiter than the male on both surfaces. Expanse of wings, $31 \mathrm{~mm}$.

Male, Moreton Bay; female, Peak Downs.

\section{LARENTIIDE.}

Cidaria, Treits.

\section{Cidaria decipiens, n. s.}

Closely allied to C. emilia of Chili, from which it chiefly differs in the absence of the yellow streaks on the veins; primaries pale leaden grey, with darker basal patch and subangulated central belt, with zigzag black margins and white borders; a narrow grey-speckled testaceous band bounding the inner edge of the central belt; an ill-defined black reniform spot; a submarginal series of more or less confluent squamose blackish spots, largest towards apex, indistinctly edged externally by a white line; secondaries grey; a faint indication of an angular whitish diffused stripe across the middle and an oblique whitish line from anal 
angle; thorax dark grey; abdomen paler grey, with darker lateral spots; under surface sericeous pale grey; wings with small black disco-cellular spots and a whitish angular discal stripe. Expanse of wings, $20 \mathrm{~mm}$.

Sydney.

Coremia, Guenée.

99. Coremia picta, n. s.

Primaries sericeous golden buff; crossed at the base by two black-edged zigzag silvery grey bands, in the middle by an irregular pale shining chocolate-brown band, widest on costa, biangulated internally and bisinuated externally, edged with black and bordered with white and silvery grey; a rather broad pale shining chocolate-brown external border, interrupted at apex by a large oval silvery white spot, and bounded internally by a series of silvery margined black spots; secondaries pale sericeous smoky grey; head and thorax dark grey, spotted with pale yellow; abdomen whity brown; under surface dark shining grey, irrorated with white; a submarginal series of white spots, bordered internally with dark grey. Expanse of wings, $19 \mathrm{~mm}$.

Viti Islands.

\section{PHYCITID床.}

\section{Salebria, Zell.}

There can be little doubt that the following species belongs to this genus; the secondaries, however, have distinctly nine veins; they appear to have twelve, as there is a strongly defined fold between the abdominal margin and the internal vein, and there are two similar (but reversed) folds between the internal and the submedian veins; in Meyrick's description, and in his structural diagnosis of the family, he appears to have overlooked the internal vein altogether. It is very improbable that any of the Phycitida can have so few as seven veins in the secondaries.

\section{Salebria squamicornis, n. s.}

Primaries pale shining stramineous; a pure white longitudinal subcostal stripe tapering at each end, passing through the cell almost to outer margin; secondaries sericeous brownish white, with yellowish reflections, semitransparent, slightly darker along the external border; fringe white, traversed near the base by a dusky line; head, collar, and tegulæ dull stramineous; remainder of body yellowish white, pearly ; primaries below pale stramineous; 
secondaries whitish, tinted with stramineous towards the outer margin; body below whitish, palpi and legs dull stramineous. Expanse of wings, $24 \mathrm{~mm}$.

\section{Peak Downs.}

Mella, Walk. (Etiella, Zell. nom. spec.).

In this genus also there appear to be nine veins (not eight) in the hind wings, the internal vein having been passed over.

\section{Mella arenosa, n. s.}

Primaries above pale sandy testaceous, the fringe slightly greyish with a pale basal stripe; secondaries semitransparent pearly greyish white, with faint golden reflections; fringe whitish, with a dusky subbasal stripe; body pale testaceous, the head and thorax slightly olivaceous; wings below sericeous, pearly; the primaries, the costa of the secondaries, and the base of the fringes in all the wings pale golden stramineous; fringe with a greyish subbasal stripe; body below whitish, legs and palpi sordid. Expanse of wings, $26 \mathrm{~mm}$.

Peak Downs.

\section{Anerastia, Hübn. \\ 102. Anerastia nitens, n. s.}

Shining whity brown; primaries sparsely irrorated with black, with an oblique line of black scales from outer fourth of dorsal margin to lower radial vein; external border somewhat more densely irrorated with black than the remainder of the wing, the atoms tending to produce a marginal series of spots and indicating a line through the centre of the fringe; thorax and abdomen somewhat ochraceous ; under surface shining whity brown, without markings. Expanse of wings, $21 \mathrm{~mm}$.

Peak Downs.

\section{CRAMBID丑.}

\section{DiptyCOPHORA, Zell.}

103. Diptycophora inornata, n. s.

Pale stone-greyish, sericeous; primaries in the female greyer than the secondaries; reniform spot large, more or less ocliraceous, and sometimes outlined in black and subquadrate; costal margin slenderly blackish, interrupted (so as to form three short dashes) towards apex; a diffused white band from centre of inner margin to costa at apex, interrupted by a slender oblique elbowed line of 
the ground colour, the angle just beyond the end of the cell; a diffused black-speckled grey streak partly bounding the white band externally; an ill-defined wavy submarginal dusky line (not visible in the male), followed by a series of elongated spots forming an interrupted stripe; external area white towards the posterior angle; outer margin slenderly dusky, undulated; fringe grey, white at the base: secondaries with the fringe grey, excepting a very slender basal line; palpi greyish; under surface whity brown, without markings. Expanse of wings, 17-18 mm. Gayndah and Peak Downs.

Explanation of Plates IX. \& X.

Plate IX.

Fig. 1. Xanthodule semiochrea.

2. Chionophasma paradoxa.

3. Leptocneria binotata.

4. Acritocera negligens; $a$, antenna.

5. Eurypsyche similis.

6. Dysbatus singularis.

7. Radinogoes tenuis.

8. Aporocosmus bracteatus.

9. Leucocosmia ceres.

10. Canthylidia pallida.

\section{Plate X.}

1. Lophocoleus mirabilis; a, tibia and tarsus, with the apex of the femur.

2. Matcomera dubia.

3. Leucophotis pulchra.

4. Egitrichus lanaris.

5. Eulocastra fasciata.

6. Gonocausta asuridia.

7. Niphadaza bicolor.

8. Hormatholepis erebina.

9. Pseudephyra straminea.

10. Pterygisus ochreipennis. 



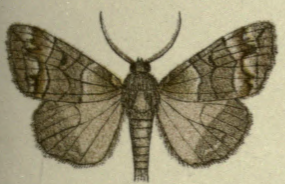

5.
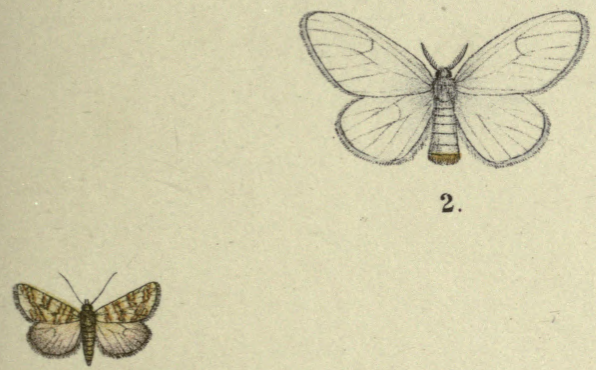

7.

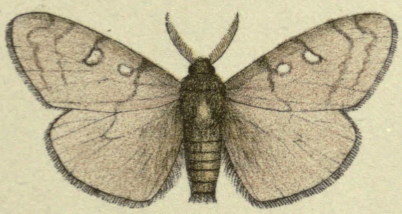

3.

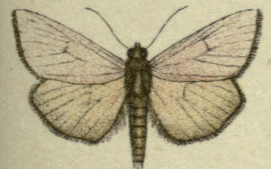

9.
2.

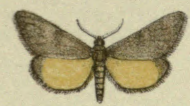

1.

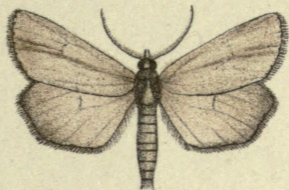

6.

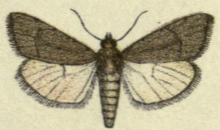

- 8.
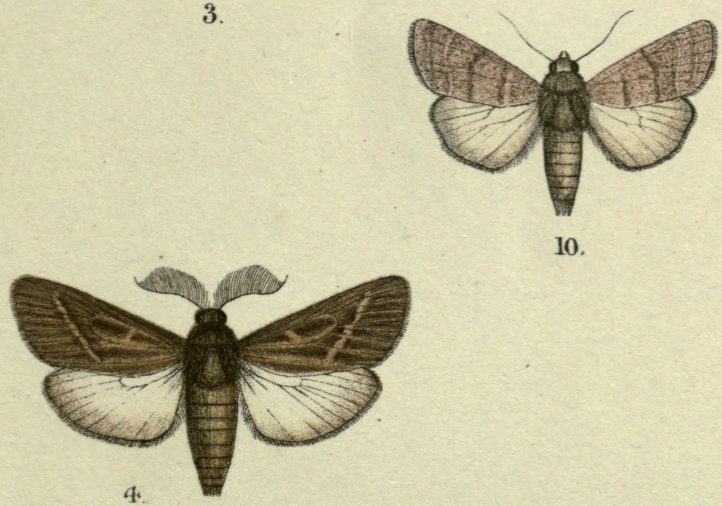

10.

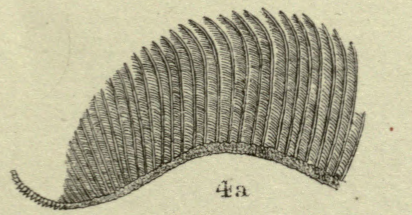

New Lepidoptera 

Trans. Ent. Soc. Lond. 1886 . Pl.X.

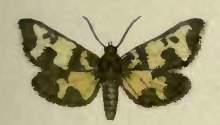

5.

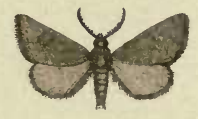

2
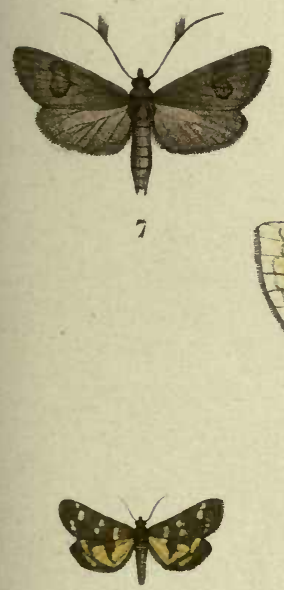

3.

3.
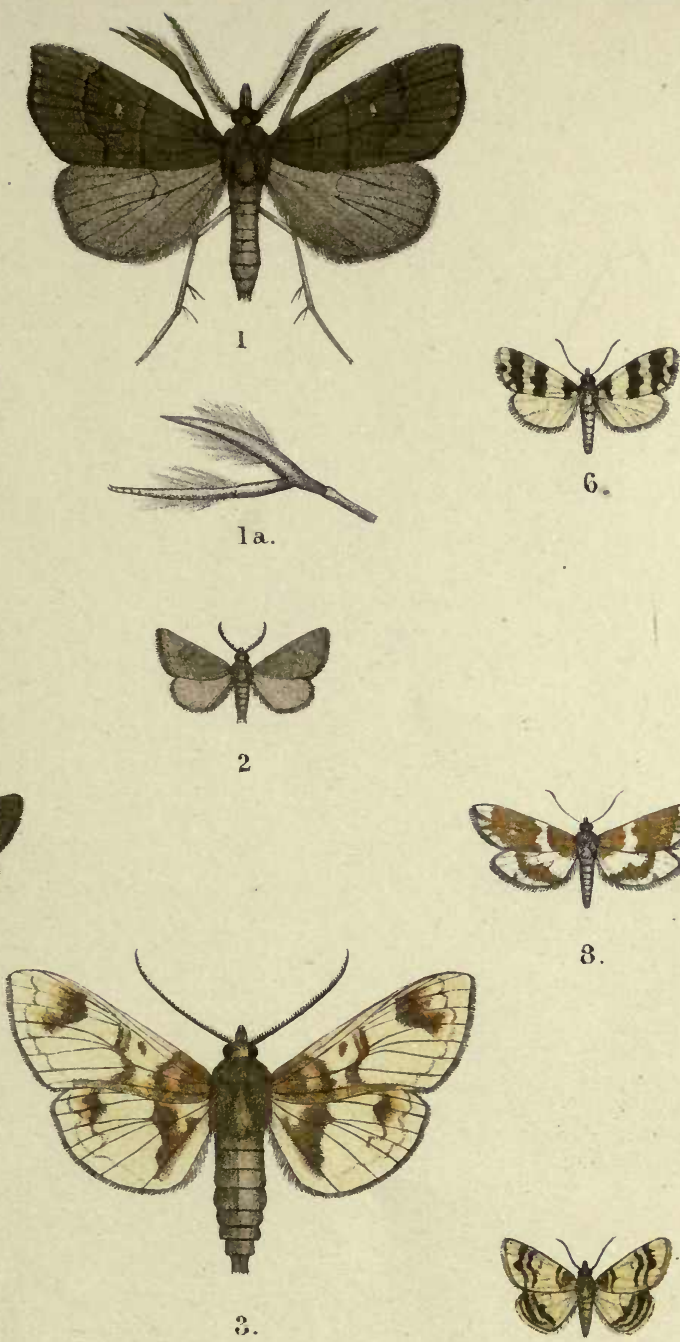

10.

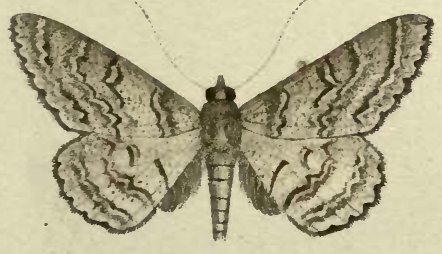

4. 

Trans. Ent. Soc. Lond, 1886 . Pl.X.

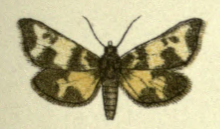

5.

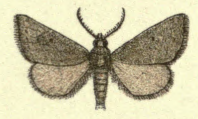

2
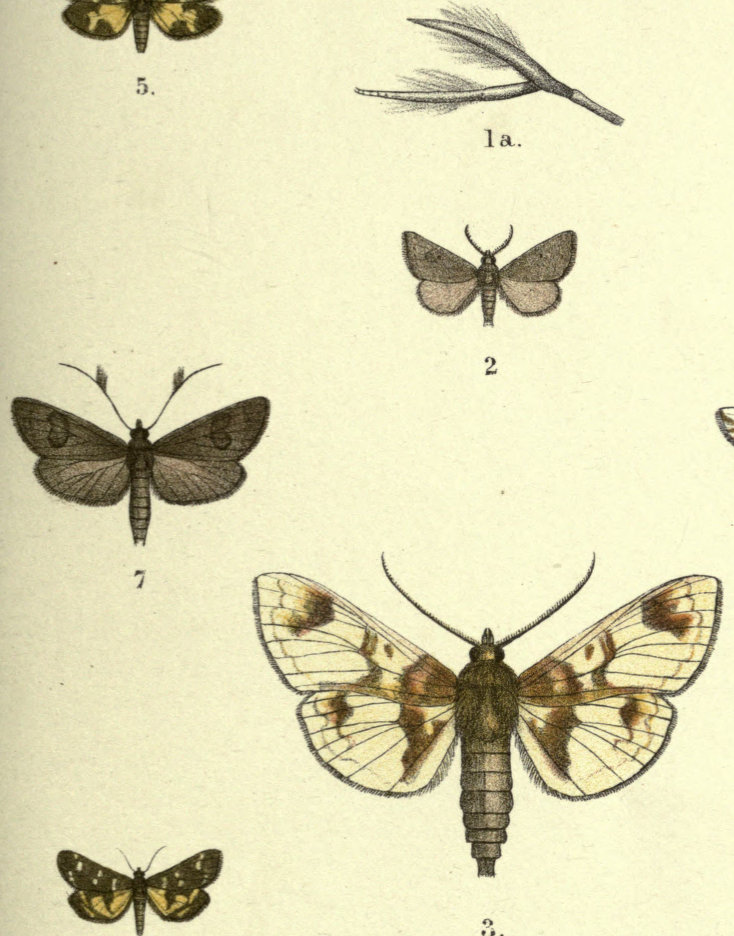

9.
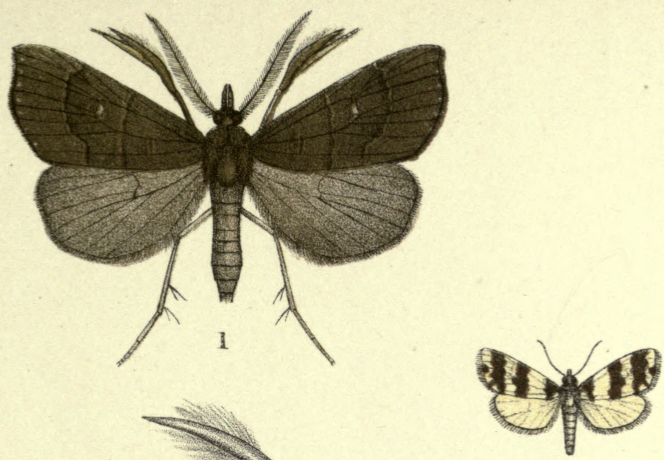

6.

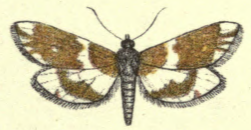

8.

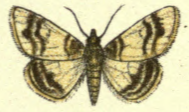

10.

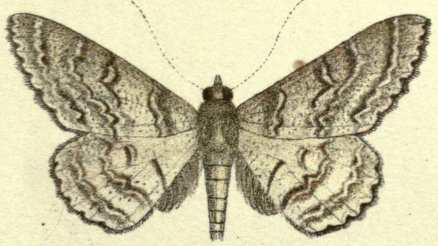

4. 


(6)

P. W.

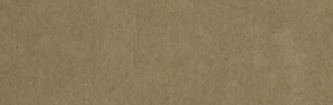

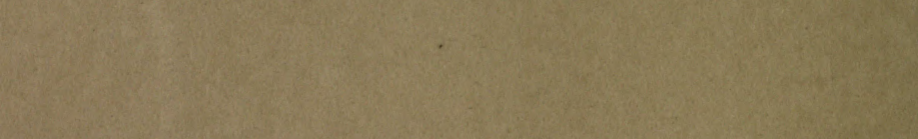

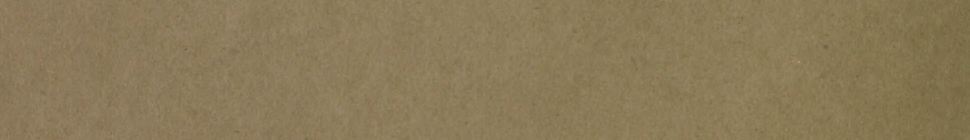

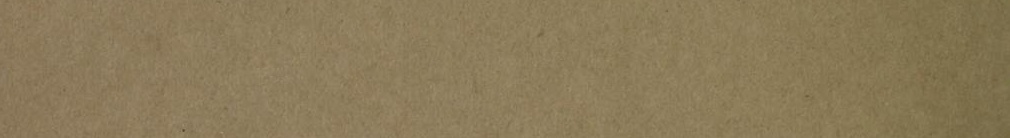
20 (1) (1)

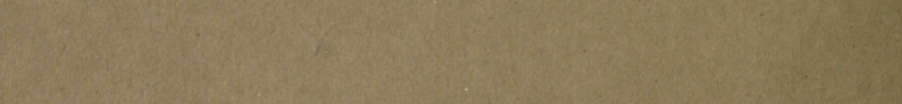

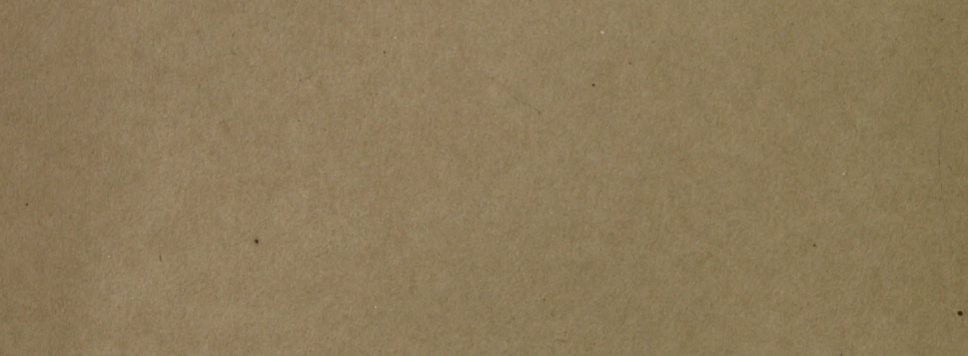

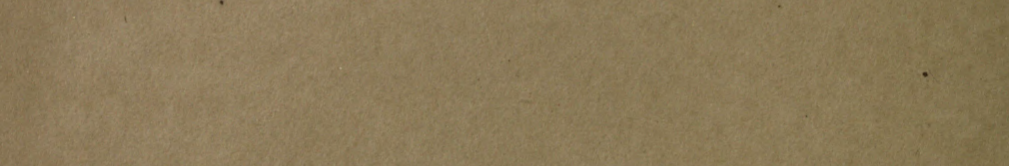

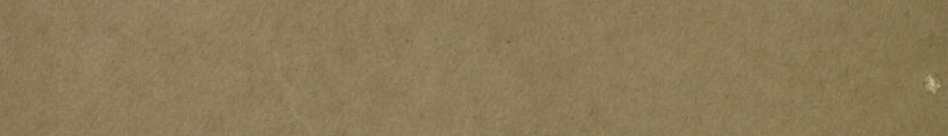

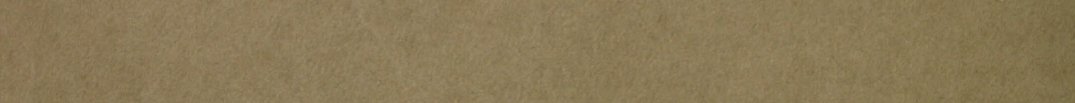

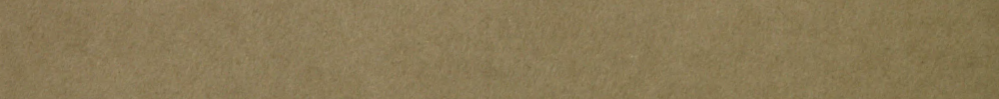
(1)

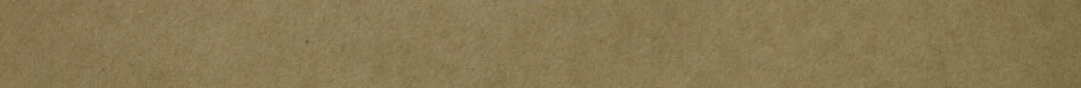

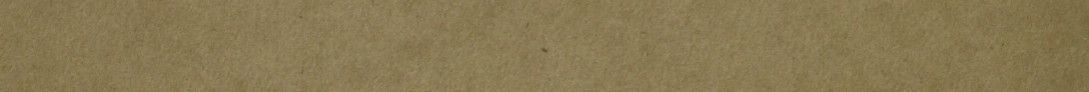
(3)

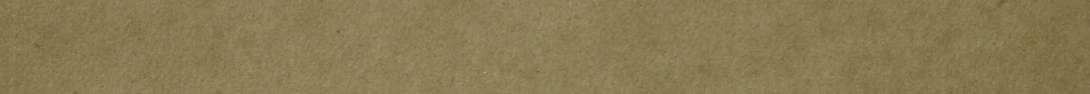

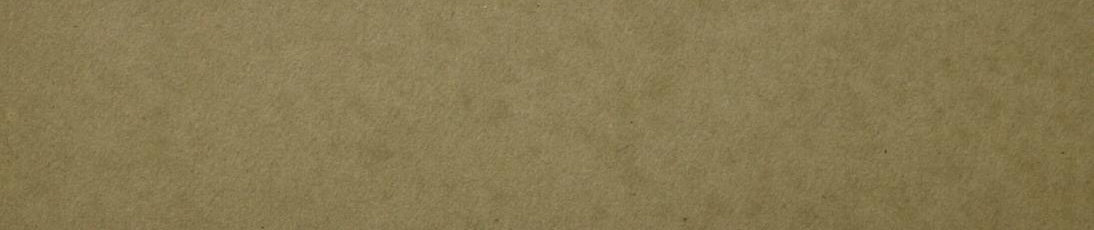


[Fron the Annals and Magazine of Natcral History for February 1887.]

Description of a new Butterfly allied to Vanessa antiopa. By Arthur G. ButLER, F.L.S., F.Z.S., \&c.

FOR some years past I have held the view that what is generally understood by the term species (that is to say, a well-defined, distinct, and constant type, having no near allies) is non-existent in the Lepidoptera, and that the nearest approach to it in this order is a constant, though but slightly differing, race or local form - that genera, in fact, consist wholly of a gradational series of such forms.

In opposition to this view certain "species" are cited as isolated, or in no way united by existing intergrades to their nearest allies, from which, moreover, they show such wide differences that the existence of intergrades is regarded as highly improbable. One of the best known and, at the same time, widely distributed of these apparently isolated species is Vanessa antiopa, which, although slightly modified locally in size and tint (the Central-American form being, usually smaller and the North-American larger and more heavily speckled than the European type), yet has no described allies 
nearer than the blue-belted $V$. glauconia, charonia, and haronica.

The forms differing from the type of $V$. antiopa $-V$. hygicea, from Europe, and V. Lintneri, from the United States - are regarded, with every likelihood of being right, as aberrations of that species; judging from Hübner's figure (lettered "antiopa") and 'Fitch's descrintion, these aberrations appear to be very similar, differing chielly from the normal form in the absence of many of the blue spots and the slightly wider yellow border of all the wings.

The following form is less likely to be a variety of $V$. antiopa than the others, since the modification of the border is not uniform and at the same time is far more remarkable; it was obtained by the Hon. Walter De Rothschild from a collection of Lepidoptera chiefly from British Honduras, but with which the collector had carelessly placed species obtained in British Guiana. At the same time, as the small form of the allied V. antiopa occur's in Mexico and Guatemala, it is more probable that the former locality is the correct one than the latter.

\section{Vanessa Thomsonii, n. sp.}

Colouring darker than in $V$. antiopa; primaries with pale straw-coloured outer border, about as wide as in that species, but heavily mottled with black, especially upon the veins; a subapical oblique yellow spot followed by five smaller decreasing and less distinct spots of the same calour, but followed by whitish scales, the whole forming an elbowed series; costa speckled with yellowish in the centre: secondaries with the basal three fifths of the same dark dull chocolate-brown as the primaries, the external two fifths, which are separated by a sharply defined, regularly dentate-sinuate line from costa to anal angle, straw-yellow, rather heavily mottled with black, but densely so upon the tail. Below, the general colouring is sericeous dark grey-brown, rather browner on the primaries than on the secondaries, striated throughout with intense black; the borders of the wings are broadly paler, of more equal width than above, bounded internally by two or three white points, and mottled with white; the fringe ochreous, interrupted by the black veins. Expanse of wings 67 millim.
British Honduras? (coll. Hon. W. De Rothschild).

It will be seen that the outer border of the secondaries in this insect is twice the width of that of the primaries, . . . 


$$
\text { Anf. } 1207
$$



Descriptions of new Species of Moths (Noctuites) from the Solomon Islands. By ArTHUR G. BUtLeR, F.L.S., F.Z.S., \&c.

THE following new species are from the collection recently sent home by Mr. C. M. Woodford.

\section{Ommatophoridæ.}

1. Nyctipao variegata, $\mathrm{sp} . \mathrm{n}$.

q. Nearest to $N$. crepuscularis, decidedly larger; the ocellus of primaries as in $N$. ephesphoris and bounded by a 
broader bone-yellowish belt than in $N$. crepuscularis; the transverse pale stripe crossing the angle of this belt very indistinct and quite perpendicular, instead of slightly oblique ; the seventh spot of the submarginal zigzag series considerably enlarged: secondaries entirely different, the basal area pale sordid buff, gradually changing to vinous brown before the middle, with a large apical darker brown patch interrupted by the usual cuneiform, subcostal, apical, white spot, which is, however, twice as large as in $N$. crepuscularis; basal fourth crossed by a blackish-brown stripe; a nearly straight diffused dark brown stripe across the middle; six submarginal black spots with whitish sigmoidal or lunate inner borders: abdomen with no basal brown band or subbasal white band, pale greyish brown or dove-coloured, with yellowish base and sides. Under surface quite unlike that of $N$. crepuscularis, pale sandy buff, with a more or less arched purplish-brown stripe before the middle of all the wings and a broad external border of the same colour enclosing a zigzag series of large white spots : primaries with a white crescentic spot at the end of the cell : secondaries with a dark brown angular discocellular spot: body below sandy buff, the anterior half of the pectus ochraceous. Expanse of wings 119 millim.

Alu, Shortland Island.

\section{Nyctipao caliginea, sp. $\mathrm{n}$.}

. Allied to N. ephesphoris, leucotonia, and dentifascia, but readily separable from all three by its slightly superior size, the distinctly broader external area, the much more angular white band across the primaries, the wider white band across the secondaries, the white and whitish zigzag series of markings on the external area well separated from the white band, the more purplish tint of, and better defined black stripes on, the basal area: the white apical spots resemble those of $N$. ephesphoris; on the under surface the white spots are large, as in $N$. ephesphoris, but the sixth spot of the primaries and the fifth of the secondaries are projected forward towards the outer margin, as in $N$. dentifascia. Expanse of wings 119 millim.

Alu.

\section{Thermesiidæ.}

\section{Sonagara superior, sp. n.}

ð. Allied to S. strigosa, Moore (Descr. Atk. p. 180, p. v. fig. 17); decidedly larger. Wings above sericeous 
pale sandy brownish, reticulated with grey: primaries with blackish costal dashes, a minute black point at the inferior angle of the cell ; an oblique straight brownish streak from outer third of inner margin to apex : secondaries with a narrow, ill-defined, brownish central band; a black spot at the end of the cell : body pale sandy brownish, darker in front. Under surface slightly paler and yellower than above, reticulations less distinct, brown stripe of primaries ill-defined; band of secondaries wanting, a well-defined black spot at the end of each discoidal cell ; palpi and front of pectus brownish. Expanse of wings 22 millim. Alu.

\section{Erosiidæ.}

\section{Erosia mutans, sp. n.}

q. Allied to a Ceylonese species (see Moore's Lep. Ceylon, pl. clxxxvi. fig. 7) of the same general tints and pattern, but larger, with broader primaries and differently formed discal stripe on these wings: primaries from base to discal stripe pale sericeous brown, mottled with grey ; external area ashgrey, mottled with slate-grey; discal stripe whitish, changing to cupreous in certain lights, straight and transverse from costa to lower radial, thence acutely angulated, running in a double zigzag to near external angle, its inferior extremity forming the outer boundary of a subpyriform, black-bordered, grey spot on the inner margin; a submarginal series of black spots bordered with whitish, changing in certain lights to cupreous; fringe similarly coloured: secondaries slate-grey, with two submedian divergent streaks from the base, an acutely angulated stripe beyond the middle, a sinuous submarginal stripe and the fringe whitish, changing to cupreous; the basal area (excepting the cupreous streaks), the inner border of the posterior portion of the postmedian stripe, and a cuneiform patch connecting its anterior portion with the outer stripe blackish brown; submarginal stripe imperfectly bordered externally with black : face bronze-brown; vertex of head and antennæ silvery white, collar dark brown, thorax and tegulæ whitish; abdomen grey, with a black transverse basal stripe. Under surface wholly leaden grey, with indistinct darker mottling on the wings; the costa of secondaries with coarse blackish fringe. Expanse of wings 24 millim.

Alu.

The above may belong to the group named Dirades by Walker, in which the sexes differ in the shape and slightly in 
the pattern of the secondaries. The following is undoubtedly a Dirades :-

\section{Dirades aluensis, sp. n.}

Allied to Erosia theclata $=E$. adjutaria (females of Dirades binotata); the sexes of the same general shapes and colours; male vinous brown : primaries with blackish costa; a semicircular black spot beyond the middle of inner margin; an oblique subapical blackish dash and an interrupted pale-edged black submarginal line; apex black on the fringe: secondaries with the basi-internal half bounded externally by a whitish line, which is elbowed just before it reaches the abdominal margin; the inferior half of the basal area bounded by a black line, its anterior half also being bright copper-red and its posterior half grey; abdominal fold white; fringe from apex to second caudate angle black. The female is greyer than the male, and, owing to the greater width of the secondaries, the angle of the line bounding the basal area is formed in the middle of the wing; the red longitudinal band from the base is darker and duller, and the whole of the remainder of the wing is grey, with the exception of a black-edged spot on basi-internal half: body greyish brown, with the antennæ and tegulæ whitish. Under surface pale brown, the secondaries paler than the primaries; the male of a more golden brown than the fernale. Expanse of wings, $\delta 18$ millim., \& 20 millim.

Alu.

\section{Hypenidæ.}

\section{Hypena iridis, sp. n.}

Primaries above brown, the basal two thirds shot with lilac in certain lights, bounded externally by a black transverse line (on the inner side of which the shot-colouring is wanting so as to leave a band of the ground-colour) edged externally with snow-white, immediately following which is a diffused band of lilacine scales; a marginal series of whitish and black dots; fringe whity brown, tipped with dark grey and with two central wavy•dark grey lines: secondaries grey-brown, with a darker marginal line; fringe whiter than in primaries; costal border whitish : body brown. Under surface sericeous greyish brown; wings with a black marginal line; fringes as above. Expanse of wings 30 millim.

Nearest to $H$. icoricalis from Ceylon, Java, \&c., with similar palpi. 


\section{Hypena sylpha, sp. n.}

Allied to $H$. molpusalis, from Ceylon ( $=H$. sparsalis, from Java); smaller and more slender, with differently formed central band across primaries: these wings are lilacine grey, crossed near the base by an ill-defined black line; a partly black-edged cuneiform brown patch from cell to inner margin, where it unites with a brown band running across the middle of the wing; this band is edged externally by a black and whitish feebly biangulated stripe; discoidal spots blackish, the reniform spot having a pale centre; three or four whitish crescents in an oblique series beyond the cell and a discal series, parallel to the outer margin, of blackish spots bounded externally by whitish crescents; a marginal series of blackish crescents bounded internally by whitish dots: secondaries greyish, with blackish marginal line; fringe whitish, spotted from apex to beyond the middle with white-centred black spots : body above greyish, darker in front. Under surface sericeous greyish; wings with a black marginal line; fringe blackish, with interrupted slender basal white line. Expanse of wings 21 millim.

Alu.

The delicate palpi of this species and $H$. molpusalis seem to me to indicate a generic distinction . between this species and the preceding one; but, until the whole genus Hypena can be thoroughly revised, it is of no use to attempt to separate isolated species. Distinctive characters which, at first sight, appear to be trustworthy may prove to graduate one into another.

\section{Herminiidæ.}

\section{Epizeuxis minima, sp. $\mathrm{n}$.}

Bone-whitish, irregularly transversely banded, but especially beyond the middle, with rufous-brown; the basal two thirds of primaries being almost clear in the type, interrupted chiefly by indications of a slightly zigzag central band, the outer edge of which is marked by a whitish line bounded towards costa by a blackish dash ; costa black-spotted; a conspicuous black spot just below the middle of the disk, and three blackish spots connected by brownish ring-spots on outer margin ; fringe ochraceous, the outer half paler, tipped with grey, the inner half varied with rufous-brown: secondaries with two black dots on an ill-defined rufous spot in the cell; a marginal chain-like border of brown ring-spots as in primaries; fringe also similar to that of those wings: body whitish, palpi tipped and banded with blackish. Under surface shin- 
ing white, with the outer half of the wings transversely striped and clouded with grey; fringes ochreous, tipped with grey and traversed by a line of the same colour. Expanse of wings 18 millim.

Alu.

\section{Aginna notata, sp. n.}

९. Pale flesh-coloured or whity brown suffused with pink; a slightly browner diffused border to all the wings: primaries with a minute black dot at the end of the cell, a few black scales sprinkled transversely across the disk, terminating in a well-marked blackish spot near external angle; a marginal series of black dots : secondaries with whitish costal area; a grey spot at end of cell; an indication of four dots, in blackish scales, crossing the median branches obliquely at about one third the distance from the cell to the outer margin and three more, the third better defined, at two thirds ; a submarginal grey streak near anal angle. Under surface of wings with a conspicuous black dot at the end of each cell, and an imperfect transverse discal series of unequal, more or less defined grey or blackish spots. Palpi and legs brownish externally. Expanse of wings 50 millim.

Alu.

\section{Aginna erebina, sp. n.}

ð. Smoky brown: primaries faintly tinted with lilacine on basal half; two widely divergent dentate-sinuate black lines, the first across the basal fourth, the second across the external two fifths, and between them a black imperfect reniform spot in outline; a straight, slightly oblique yellowish line across the disk ; a marginal series of conical black spots; fringe traversed externally by a pale grey line : secondaries with a dusky spot at end of cell followed by an oblique dusky stripe; a slightly sinuous yellow stripe across the disk, bent upwards near anal angle; marginal spots and fringe as in primaries : palpi pale ochreous ; abdomen greyish, with narrow whitish edges to the segments. Under surface very dark, smoky brown; wings with conspicuous black spots at the extremities of the discoidal cells, an arched or bent blackish stripe beyond the middle, and a somewhat dentated pale-bordered discal blackish stripe; marginal spots and fringes as above : legs clothed with dense masses of black-brown appressed hairs. Expanse of wings 46 millim.

Alu.

Though coloured like a Herminia the structure of the antennæ, palpi, and legs proves it to be a true Aginna. 


\section{Bocana stellares, sp. $\mathrm{n}$.}

Allied to $B$. cesopusalis (of which Diomea bryophiloides is a distorted specimen) : primaries sericeous grey-brown, bronzy in certain lights, crossed at about basal fourth by a crinkled black line; reniform spot white with black edges; an arched denticulated white-edged blackish line beyond the middle; a zigzag series of more or less connected white spots and crescents near outer margin, and a marginal series of triangular jet-black spots, relieved on the fringe by a series of subconfluent white spots: secondaries paler and greyer than primaries, with a white-bordered angular grey line beyond the middle, and a second, abbreviated, towards anal angle; a slender black marginal line followed by a white line at the base of the fringe : thorax slightly ochreous, brown; abdomen grey, with two or three white dorsal spots. Under surface brownish grey, with a faint lilacine tint in certain lights; all the wings with a black-edged white spot at end of cell, and two more or less irregular black discal lines, the outer one interrupted, more or less separated into distinct spots and white-edged externally; a slender black marginal line, followed by a slender white line at the base of the fringe: body below golden brown. Expanse of wings 24 millim.

Alu.

\section{Egnasia cenea, sp. $\mathrm{n}$.}

Primaries whity brown, with brassy reflexions; costal border blackish at base; orbicular spot small, black ; reniform spot large, $\mathrm{d}$-shaped, black; two black dots towards base of interno-median area; a longitudinal white streak, interrupted by the ordinary black spots, through the discoidal cell; an irregularly sinuous white discal band, bounded on both sides by a series of subconfluent black spots; external border suffused with smoky brown: secondaries of male white, with a subquadrate basi-internal blackish patch, a black discocellular spot, a black discal line, its central third arched outwards, and a tolerably broad external brown border following the discal line so as to leave a band of white between; secondaries of female either as in the male or with the basal area as far as the discal line brown : face, vertex of head, and mesothorax brown, remainder of body white; terminal joint of palpi and antennæ yellow. Under surface whitish varied with testaceous, the latter colouring replacing the brown of the upper surface; black markings ill defined; the whole surface of the wings sericeous, with brassy reflexions. Expanse of wings 18-26 millim.

Alu. 
Allied to "Hypenodes" jucundalis of Snellen (Tijd. voor Ent. 1886, pl. v. fig. 10); but I do not see how it differs from Egnasia, and it certainly has little in common with Hypenodes.

\section{Ballatha elegans, sp. $\mathrm{n}$.}

Allied to $B$. atrotumens * primaries above pearl-grey, suffused towards base and on costal area towards apex with brownish; a broad oblique white belt from costa before the middle to the external angle, whence it curves upwards to apical third of outer margin, whence to apex it becomes very narrow and obscure; the projecting patch of scales just beyond the middle of inner margin elliptical, blue-grey and black spangled with silver; a few scattered silver scales on basal area and others indicating the ordinary position of the discoidal spots, a few bounding a brownish costal patch immediately beyond the white belt; a silver stripe forming the inner boundary of the brownish apical patch; a brighter silver lunulated marginal stripe; fringe grey; subapical ocellus large, oval, black, with linear yellowish pupil and iris of the same colour; a small black apical spot: secondaries clear, soft, golden ochreous, paler on the costa and fringe; a diffused grey apical patch: head and collar testaceous, with micaceous shining scales on the face and vertex of head; tegulæ slightly greyer with similar scaling; thorax grey; antennæ whity brown; palpi ochreous; abdomen pale, soft, ochreous. Under surface bright clear ochreous, the body whitish, the legs tinted above with ochreous; primaries with an oblique, abbreviated, broad, dark grey band on the disk. Expanse of wings 40 millim.

Alu.

This is by far the most beautiful species of this singular genus hitherto described. 


Description of a new Genus of Chalcosiid Moths allied to Pedoptila. By Arthur G. Butler, F.L.S., F.Z.S., \&c.

In the 'Annals' for 1885, vol. xv. pp. 340-342, I described a remarkable new genus of moths allied to Himantopterus; the type was from Cape Coast and in the collection of Mr. F. Swanzy, who has since presented it to the Trustees of the British Museum.

A second genus from Zanzibar was described by Herr Rogenhofer, of Vienna, under the name of Doratopteryx, in the 'Sitzungsberichten der k.-k. zoolog.-botan. Gesellschaft in Wien' (vol. xxxiii.); and in the 'Annals' for 1885, vol. xvi., I have compared the characters of the two genera Pedoptila and Doratopteryx, pointing out in what respects they differ both in structure and aspect.

Whilst recently looking over some Lepidoptera brought to me for examination by Mr. Philip Crowley, I was delighted to find a third very distinct genus of this group, nearer to Pedoptila than to anything else hitherto described, but differing remarkably in neuration and in the form of the secondaries.

Semioptila, gen. nov. ( $\sigma \eta \mu \in \hat{\epsilon} o \nu, \pi \tau i$ i $o v)$.

Nearest to Pedoptila: primaries more elongated and narrower, the subcostal vein four-branched, an extra nervule being emitted before the end of the cell, the second and third branches forming a narrow apical furca, the fourth emitted also at some distance beyond the cell, as in the case of the third branch of Pedoptila; cell open, the termination only indicated by a darker transverse line on the surface of the wing; upper radial reduced to a false vein, thickest at outer margin, and passing through the cell almost to the base of the subcostal vein; lower radial emitted as a fourth median branch, but not from the same point with the third median (as in Pedoptila); submedian vein much more nearly approaching the first median branch at its distal extremity: secondaries elongate trigonate, apparently twisted over, so as to bring the costal margin next to the body, in which position it is naturally retained, the anal angle of the wing is thus represented by an obtusely angulated apex, and the apex by an acute anal angle; the subcostal vein, which is forked before the apex, thus represents a two-branched median vein, whilst the median vein becomes a simple subcostal vein ${ }^{*}$; discoidal cell open as in the primaries : body

* Thus viewed, the three veins remain as in Pedoptila, the wing itself being altered in shape and reversed. 
Mr. A. G. Butler on a new Genus of Chalcosiid Moths. 181 very similar to that of the allied genera, the abdomen, however, is closely but coarsely scaled.

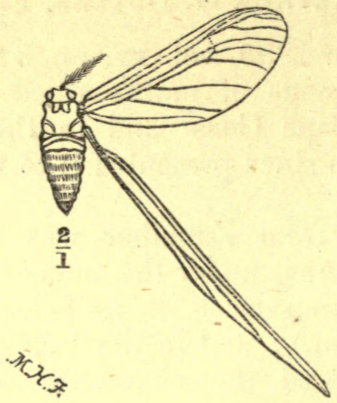

Semioptila torta, sp. n.

Wings transparent, sparsely scaled, the basal half with rustreddish or reddish-orange scales, the outer or terminal half with brown scales; secondaries with an oval orange spot beyond the cell; body pitchy brown, the abdomen with cupreous-brown scales; vertex of head and collar orange : under surface pale brown, with a few orange hairs on the pectus. Expanse of wings 24 millim.

Congo (coll. P. Crowley). 
Nó. 1804 


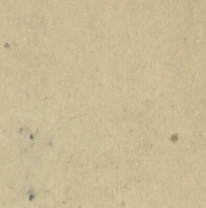

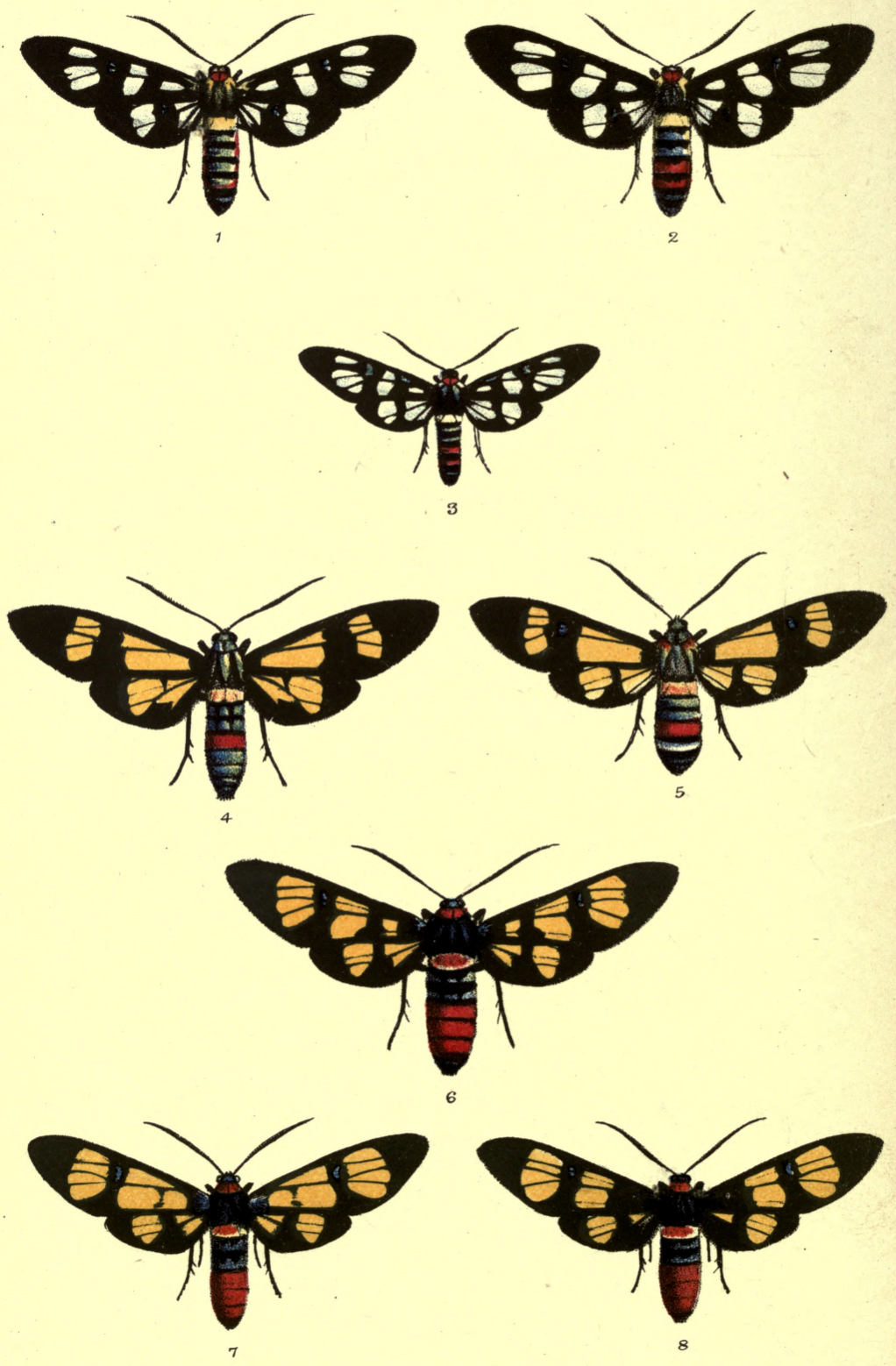
III. Notes on the species of the lepidopterous genus Euchromia, with descriptions of new species in the collection of the British Museum. By Arthur G. BUTLER, F.L.S., F.Z.S., \&c.

[Read November 2nd, 1887.]

Plate IV.

THe genus Euchromia contains some of the most brilliantly coloured of all the tropical Burnet-moths; the greater part of the species are well represented in the National Collection, and form as beautiful a group, and as worthy of public attention, as the humming-birds in the class of Aves.

My attention has been at this time specially called to the genus by the receipt of a paper by Herr Röber of Dresden, in which four supposed new forms are described, only one of which I regret to say will be able to stand.

In my examination of the species I have been assisted by my colleague, Mr. W. F. Kirby, who has not only sent me for my use his MS. Catalogue of the genus, but has re-examined with me all species in the collection the verification of which was in any way open to doubt.

About twenty-five species have been described; I say " about," because two forms, $E$. aruica and $E$. ganymede, are only doubtfully distinct from $E$. irius and $E$. creusa respectively. The following is a list of the species in the Museum collection.

1. Euchromia gemmata, Butler. (Pl. IV., fig. 1).

One fine example only of this very distinct species, obtained by Mr. Woodford in the Solomon Islands.

\section{Euchromia rubricollis, Walker.}

Aneiteum and Mallicollo. We have a series of this species collected by Mr Gervase Matthew, and nine examples have been reserved to illustrate the species.

TRANS. ENT. SOC. LOND. 1888. PART I. (MARCH.) 


\section{Euchromia lurlina, n. s.}

About the size of $E$. isis; general pattern of wings as in $E$. creusa, the primaries being black with six hyaline white spots and two or three metallic blue spots, the secondaries with two spots divided by the nervares and a blue spot between them; the spots of the primaries differ from those of $E$. creusa as follows,-the pair separated by the median vein form an oblique oval; and the pair separated by the third median branch, as well as the isolated spot above them, are elongated to twice the length and therefore more nearly approach the outer margin; body black, the frons and margin of eyes snow-white, the shoulders and base of abdomen pale ochreous, the shoulders also opaline; the centre of tegulæ and metathorax metallic greenish blue; the second and third abdominal segments bordered behind with blue and with bright ochreous at the sides, the fourth segment broadly bordered with vermilion; remaining segments with extremely narrow blue edge; coxæ pearly white; body below dark brown, the fourth abdominal segment edged with ochreous. Expanse of wings, $38 \mathrm{~mm}$.

One example of this very distinct species, from Thursday Island, was purchased in 1880.

\section{Euchromia isis, Boisduval.}

Of this very pretty species we only have one specimen, from Duke of York Island; it was obtained by one of the collectors for the Godeffroy Museum, and was purchased in 1882.

\section{Euchromia aruica, Walker.}

As already stated this may not be distinct from the $E$. irius of Boisduval, from which it chiefly differs in the size and width of the hyaline spots on the wings.

Two examples, Aru (Wallace).

6. Euchromia amulina, Butler.

Allied to the preceding, though unquestionably distinct; we only possess one example, from New Guinea. 
7. Euchromia calipennis, Walker.

Two examples from Amboina; it also occurs in Ceram, and has recently been described and figured by Herr Röber, under the name of Glaucopis pagensteckeri.

8. Euchromia anone, Butler. (Pl. IV., fig. 2).

One of the most beautiful species in the genus; we have a good series collected by Messrs. Woodford and Mathew in Alu, Sta Anna, Guadalcanar and Malayta (Solomon Islands).

9. Euchromia mathewi, n. s. (Pl. IV., fig. 3).

Allied to the preceding; decidedly smaller, the primaries with the subbasal elongate spot and the spot above the median vein smaller; the discal patch divided into three, instead of two large spots; the basal patch of secondaries much wider, in the female uniting with the trifid patch beyond; the body is more slender than in $E$. anone, the shoulder spots pearly white instead of ochreous, the basal segment white at the sides, anterior coxæ snow. white instead of metallic green, the metathorax with two metallic green spots placed obliquely on each side, the crimson abdominal segments completely encircling the abdomen; the black intervening stripes being narrower than above, but not interrupted. Expanse of wings, $36-41 \mathrm{~mm}$.

Solomon Islands: Three examples collected by Mr. Gervase Mathew.

\section{Euchromia creusa, Linn.}

This is the species figured by Cramer under the name of Sphinx irus, and by Herr Röber, under the name of Glaucopis dubia. I believe $S$. thelebus to be a representation of a worn example of the same species (such as we have from Ceram); our series consists of two examples from Ceram, three from Gilolo, one from the Celebes, one from the Pelew Islands, and one from the N.E. coast of Australia.

\section{Var.? Euchromia ganymede, Doubleday.}

This handsome form is the commonest and most variable of the group ; it differs from typical $E$. creusa principally in the much greater size of the hyaline spots on its wings; the outer spots of the primaries vary from three 
to four and occasionally five, the anterior coxæ are either snow-white or metallic green (in specimens from the same island); the basal segment of the abdomen is either wholly green, or has the centre black, or has the sides opaline whitish and the centre brownish orange; grades between these variations also occur, proving that they have, in this species, no specific value; the black bands across the carmine also vary in width. We have a series of twenty-one examples in the collection from Australia, Ké Island, the New Hebrides, Lizard Island, Treasury Island, Pentecost, Guadalcanar, Alu and Malayta, of the Solomon group.

To this section of the genus belongs the Glaucopis paula of Röber, from East Celebes, a small species apparently allied to $E$. calipennis, but unknown to me. It is possible that $E$. cincta, of Montrouzier, may also come into this section, but the secondaries are described as having four yellow spots upon them, an entirely new feature among the hyaline winged species.

The following are species in which the primaries and nearly the whole or sometimes the. whole of the secondaries are opaque.

\section{Euchromia lethe, Fabricius.}

This is the Sphinx eumolphus of Cramer, and was confounded by Walker with the following very distinct species under the name of $E$. sperchius; it is a common S. African species, and we have it from Natal, the Cape, and Madagascar.

\section{Euchromia fulvida, n. s. (Pl. IV., fig. 5).}

The West African representative of the preceding, and equally common; it differs in having the pale patches on the wings deep fulvous instead of sulphur-yellow; the metallic markings less blue, and the fifth segment of the abdomen pearly greenish-white instead of metallic green like the posterior segments; the anterior coxæ metallic green instead of pure white. Expanse of wings, $45-54 \mathrm{~mm}$.

Thirteen examples, from the Congo, Angola, Sierra Leone, \&c., are in the Museum series. 
13. Euchromia splendens, n. s. (PI. IV., fig. 4).

Differs from the preceding in the blacker colouring of the wings, he absence of the metallic spots between the deep fulvous patches on primaries, the much less distinctly separated fulvous patches on the secondaries, the total absence of all orange or red colouring from the thorax; this part of the body is jet black, the head, sides of collar, tegulæ (excepting the fringes) and a dorsal longitudinal stripe brilliant greenish blue; the basal abdominal segment is more orange and the fourth segment of a deeper red than in E. fulvida, and all the other segments are brilliant metallic greenish blue, the second and third segments edged with black. Expanse of wings, $49-53 \mathrm{~mm}$.

Old Calabar to Camaroons.

\section{Euchromia africana, Butler.}

A common African species intermediate to some extent between $E$. splendens and $E$. madagascariensis, the secondaries being like those of the former, the primaries and body more nearly resembling the latter species: we have seven examples from Natal, Zululand and Delagoa Bay.

\section{Euchromia madagascariensis, Boisduval.}

Two specimens from Madagascar. The $E$. amena of Moeschler, said to have come from Silhet, seems nearly allied to this species. Is it positively certain that the locality is correct? Surely it would be in Mr. Moore's vast Indian collection.

\section{Euchromia leonis, Butler.}

The body of this species resembles that of E. splendens, the wings, however, are wholly different. We have three specimens from Sierra Leone.

\section{Euchromia sperchius, Cramer.}

This is the E. interstans of Walker, represented by two examples from Ashanti.

\section{Euchromia horsfieldii, Moore.}

Five specimens, collected by Dr. Horsfield in Japan, are in the Museum series.

TRANS. ENT. SOC. LOND. 1888.-PAR'T I. (MARCH.) I 
19. Euchromia formosana, n. s. (Pl. IV., fig. 7).

Pattern of primaries nearly as in $E$. horsfieldii; the orange patches wider; the interno-median patch partly divided before the middle by two black dots placed obliquely; secondaries nearly as n $E$. polymena, but the basal patch smaller; body as in $E$. orien. talis, the fourth to sixth segments being carmine-red. Expanse of wings, $48 \mathrm{~mm}$.

Formosa (Hobson).

20. Euchromia fraterna, Butler.

A species occurring in Moulmein, of which, at present, we have only one example, but which (judging by the constancy of its allies) is almost certain to be a fixed type ; Herr Röber, however, says that he agrees with Herr Snellen in regarding this and E. celebensis as "insignificant aberrations, unworthy of names;" after which he proceeds at once to give one of them a new name himself.

21. Euchromia orientalis, Butler. (Pl. IV., fig. 6).

The common Burmese representative of $E$. polymena: the type unfortunately was labelled "N. India"-doubtless an error, as the species has since come in some numbers from Burmah; though, unhappily, many of them were so much injured as to be unfit to put into the collection.

22. Euchromia polymena, Linneus.

We have eight examples, from India and Ceylon.

23. Euchromia celebensis, Butler.

Four specimens from the Celebes: this is the Glaucopis butleri of Röber; he says that it differs from $E$. celebensis, in having the "lower radial of the primaries broadly bordered with black"-a slightly variable but constant character of E. celebensis.

\section{Euchromia laura, Butler. (Pl. IV., fig. 8).}

Although we only have one example of this species, and with the vague locality "E. India," it is so wellmarked that its distinctness can be considered certain. 
25. Euchromia siamensis, Butler.

One example only, from Siam.

In one of his 'Revisions of Australian Lepidoptera,' Proc. Linn. Soc. N. S. W., 2nd ser., vol. i. p. 787 (1886), Mr. Meyrick describes what he regards as Euchromia polymena from North Australia. Judging by his description of the markings of the primaries, I have no hesitation in pronouncing it to be perfectly distinct from the Indian species. As, however, I have not seen the broken specimen from which Mr. Meyrick penned his description, I leave it to him to give it a distinctive name: it probably should stand near the following.

26. Euchromia semiluna, Walker.

A very distinct species founded upon a single example, the habitat of which is unknown.

Explanation of Plate IV.

Fig. 1. Euchromia gemmata.

2. " anone.

3. " mathewi.

4. ", splendens.

5. ", fulvida.

6. " orientalis.

7. ", formosana.

8. ", laura. 


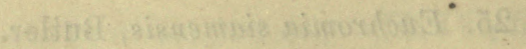

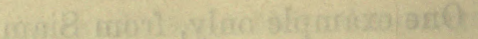

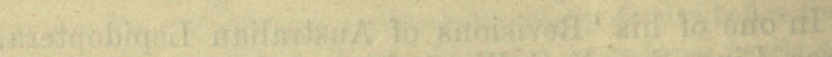

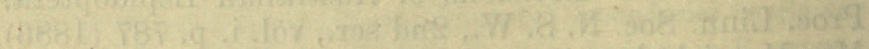

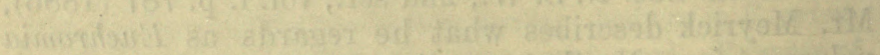

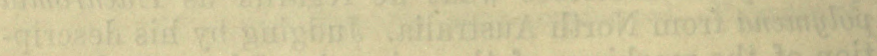

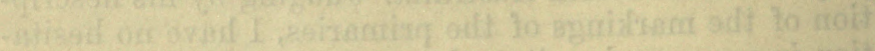

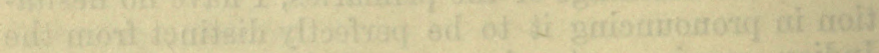

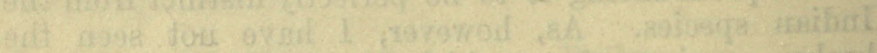

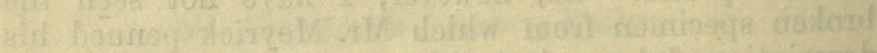

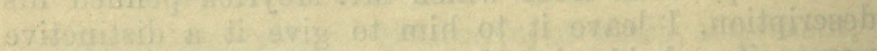

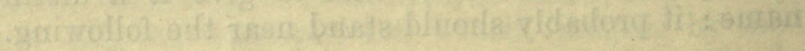

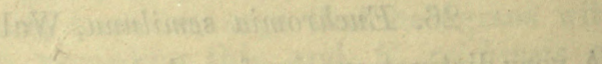

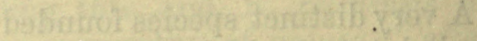

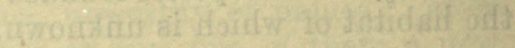

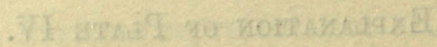

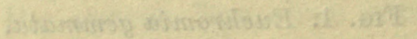

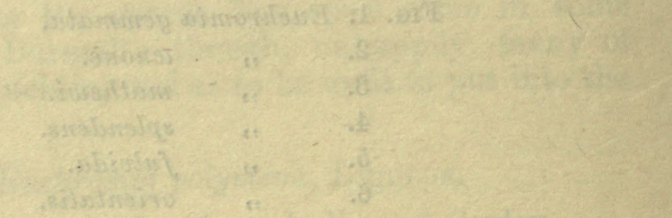

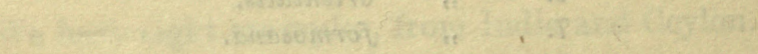
withing 


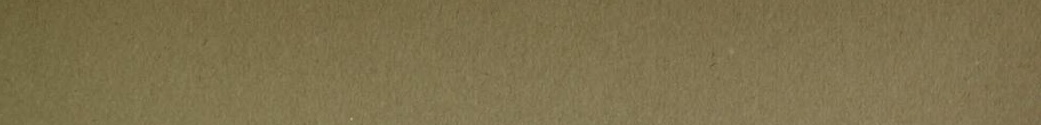

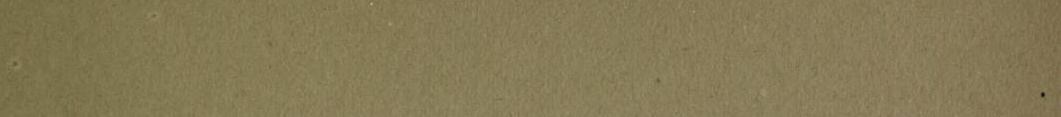

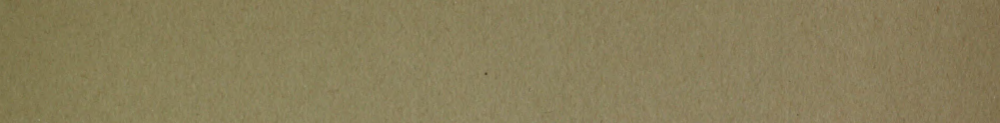

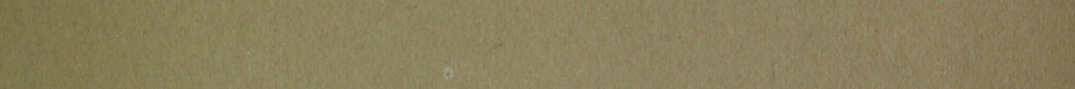

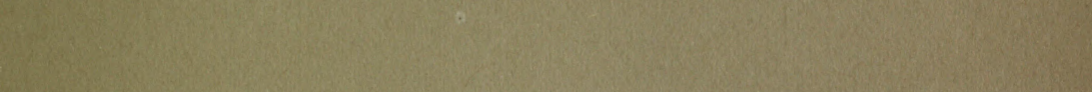

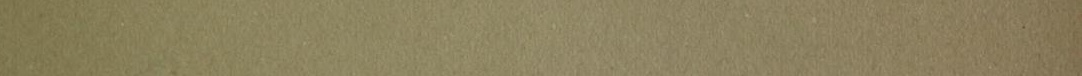

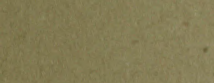

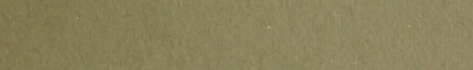

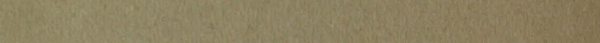
A

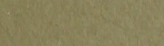

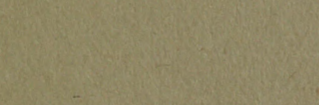

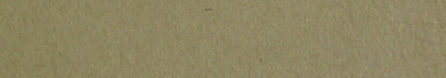

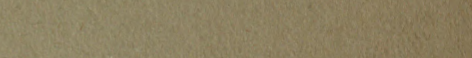
(3)

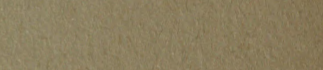

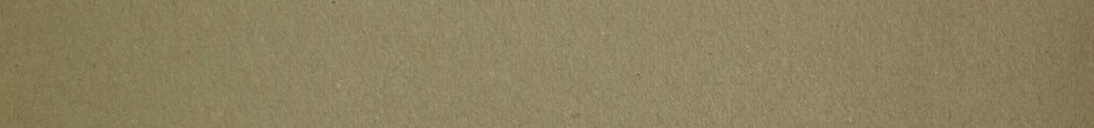

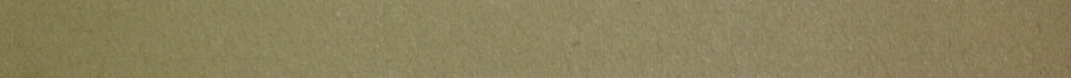

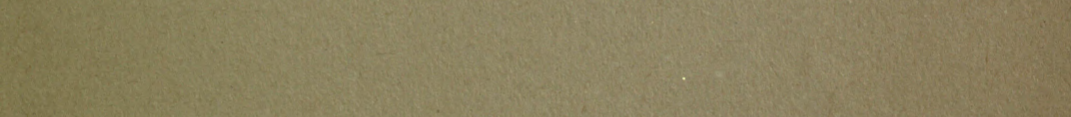

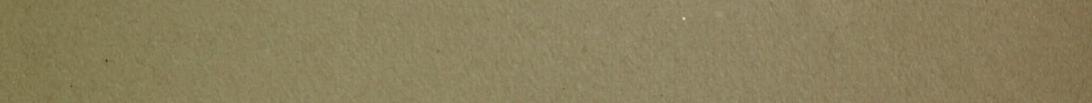

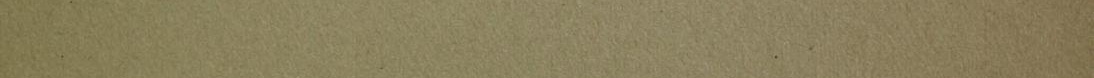

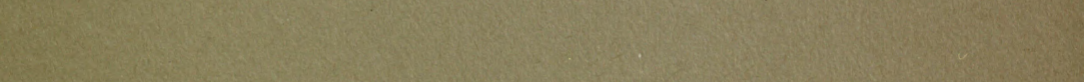

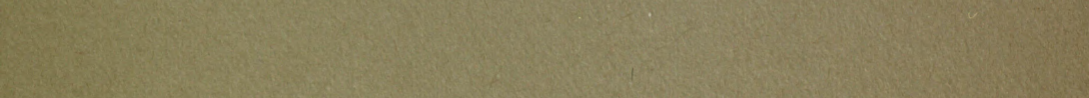

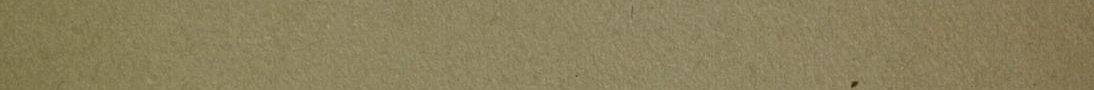

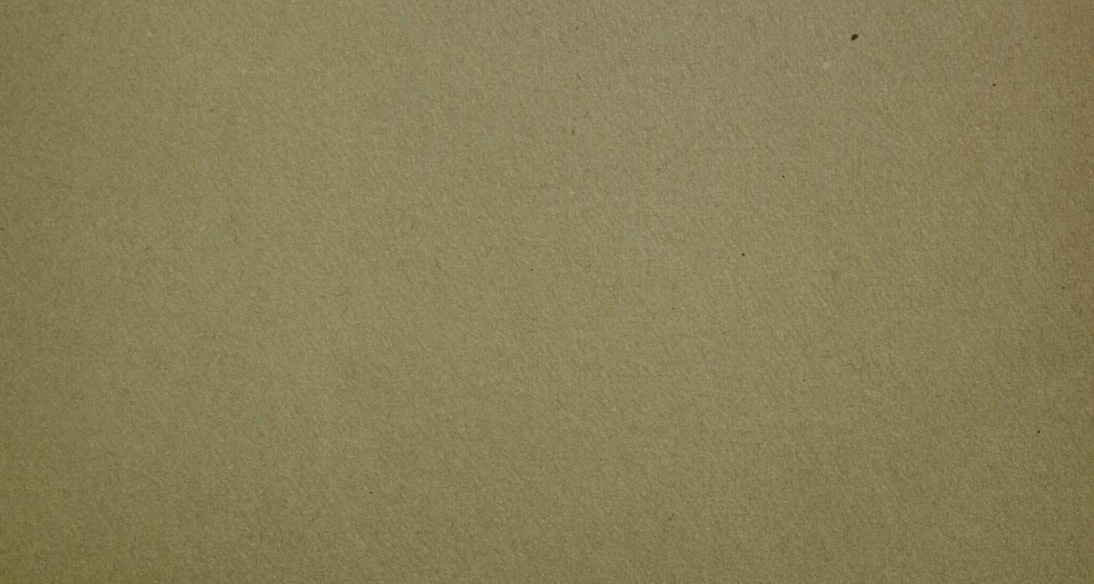





$$
\text { fori: lope }
$$


Descriptions of some new Lepidoptera from Kilima-njaro. By Arthur G. Butrer, F.L.S., F.Z.S, \&c.

Examples of some of the species here described were collected by the late Bishop Hannington and of others by Mr. F. J. Jackson; in not a few cases specimens of the same species were obtained by both gentlemen.

\section{RHOPALOCERA.}

\section{NYMPHA L I D E.}

Euplocina.

\section{Amauris hanningtoni, sp. n.}

Primaries black, with pure white markings as in $A$. egialea, excepting that all the larger spots are reduced one third in size; secondaries dark brown, with a sharply defined oblong belt united by a short band to costa, from the abdominal margin to a little above the cell, sordid white; seven submarginal white spots, the relative sizes of which, reckoning from costa, are $4,6,5,1,2,7,3$; two or three white dots nearer to the margin; under surface only differing from the upper surface as in the allied $A$. egialea and A. hyalites. Expanse of wings 81 millim.

Two males; Hills of Terta in April (Hannington).

\section{ACraine.}

The female of Acraa (Planema) johnstoni of Godman was in the same collection and is evidently modified in imitation of the foregoing Amauris; it is black, with four white spots arranged obliquely in pairs and a dull white or yellowish belt across the secondaries as in the male; the receipt of this female is most interesting, as it is a clue to the position of the species, which is clearly seen to be allied to $A$. $(P$.) lycoa from the west coast; one example was received from the Hills of Terta, another between $3000-8000$ feet on the slopes of Kilima-njaro in March.

\section{Planema montana, sp. n.}

$\delta^{5}$. Allied to $P$. aganice, but differing in the bright orange-fulvous colour of the bands and in the greater width of the angulated band of primaries. Expanse of wings 68 millim.

Slopes of Kilima-njaro, 3000-5000 feet, in March (Hannington).

\section{NYMPHALINE.}

\section{Euryphene violacea, sp. n.}

б 9 . Allied to $E$. neophron of Hopffer (a common Zanzibar species), but differing in the purple instead of greenish-blue coloration of the upper surface, the narrower and duller orange-ochreous belt across the black apical half of primaries, and the more prominent 
longer apical ochreous patch; on the under surface the groundcolour is suffused with yellow instead of with lilac, and the white markings are washed with yellowish; a distinctly dull yellow patch replacing the white spot at apex of primaries. Expanse of wings of 70 millim. ; 987 millim.

Slopes of Kilima-njaro, 3000-5000 feet, in March (Hannington).

This appears to be a fairly common species, it was also obtained by Mr. Jackson; but, unfortunately, his specimens were all more or less damaged by some larger insects, which got loose in the box and broke them on the way home.

Amongst other Nymphalina, Mr. Jackson obtained Eurytela dryope and $\boldsymbol{E}$. ophione and a Neptis allied to $N$. melicerte (two specimens of which from Zanzibar stand in the Hewitson collection along with the latter species).

4. Neptis goochir, Trimen, var.

Nearly allied to $N$. melicerte, but the white discoidal patch of primaries reduced to a small spot near the end of the cell; the large discal spots wider, those of the upper patch placed less obliquely and therefore more compactly together; the belt of secondaries broader and with more convex inner edge; on the under surface the discoidal spot is large and fills the cell, but the other differences hold good. Expanse of wings 44 millim.

Kilima-njaro ( $F$.J. Jackson).

The specimens from Zanzibar are smaller and the discoidal spot - is a little larger than in the type; they represent the common form of the species.

\section{PAPILIONIDE.}

\section{Pierine.}

Mr. Jackson obtained no less than eleven species of Teracolus, and Bishop Hannington two others, viz:-

Teracolus mutuns. In the forests of Tiveta (Hannington).

- aurigineus. In the furests of Tiveta (Hannington and Jackson).

- venustus, sp. n. Kilima-njaro (Jackson).

- chrysonome, of 오. Kilima-njaro (Hannington)

- calais, ot + . Kilima-njaro (Jackson).

— leo, 0 . + . Forests of Tiveta (Hannington and Jackson).

- miles, $\delta$. $q$. Slopes of Kilima-njaro (Hannington and Jackson).

- pseudacaste, $\delta^{\star}$. Slopes of Kilima-njaro (Jackson).

— citreus, of $q$. Slopes of Kilima-njaro (Jackson).

- incretus, $\delta+q$. Forests of Tiveta (Hannington and Jackson).

- antevippe, ot. Kilima-njaro (Jackson).

- omphaloides. Kilima-njaro (Jackson).

- comptus, sp. n. Kilima-njaro (Jackson).

In my monograph of Teracolus (P.Z: S. 1876), I placed T. leo as synonymous with $T$. halimede of Klug; my type was a faded and 
somewhat worn male, received from the White Nile; the fresh specimens now in the collection prove me to have been wrong in duing so, the characters which distinguish the two forms being well marked and constant. In $T$. leo the saffron-yellow of the primaries extends only from the inner margin upwards to the first median branch, whereas in $T$. halimede it spreads to above the third branch; all the black markings are smaller and much more prominent in $T$. leo, but the female has a blackish bar across the cell of primaries, limiting the grey basal area; this sex also has the apex of primaries and the whole ground-colour of secondaries of a sandy-buff hue, the latter wings having a conspicuous white spot at the end of the cell and an unevenly arched series of brown spots across the disc; some females have no saffron-yellow on the upper surface.

The ferrale of $T$. miles proves to be a black-and-white form, not unlike the white female of $T$. pseudacaste, but with less black above, the veins at apex of primaries below not blackened, and the secondaries buff instead of white; there is, however, a red-tipped female which, I think, belongs to the same species and which has the apex of primaries and ground-colour of the secondaries below sulphuryellow. The female of $T$. citreus from Kilima-njaro is, on the upperside, very like that sex of 'T. topha, but the black markings are reduced and more sharply defined; below it more nearly resemb'es T. xanthevarne \&, the secondaries white with pale yellowish-brown markings and olive and black mottling as in T. eucharis $q$, but with a conspicuous brown-edged white discocellular spot.

The synonymy of $T$. incretus will, as I suspected, stand as follows :-

TERACOLUS INCRETUS.

․ Teracolus incretus, Butler, Ent. Month. Mag. xviii. p. 146 $(1881)$.

6. Callosune vulnerata, Staudinger, Exot. Schmett. pl. 23. fig. 21 (1884).

Both sexes of this, the largest species of the T. evarne group, were obtained both by Bishop Hannington and Mr. Jackson; so that there is now no doubt of the correctuess of my expressed opinion that $C$. vulnerata would prove to be the male of my species; the figure by Staudinger is poor, the colouring of the secondaries being exaygerated and the black bordering of the primaries incorrectly drawn, still it is is good as the majority of the illustrations in this book, which (whatever its faults may be) has the merit of being cheap. As with other species of the $T$. evarne group, a white form of the female is by no means uncommon; it is a litile smaller than the yellow female and, excepting in its superior size and in the details of marking on the under surface, greatly resembles that sex of T'. topha.

The male, on the under surface, is extremely variable; indeed $n$ o two specimens are alike; the following may be noted:-

$a$. Secondaries below whitish sulphur, excepting at the borders, which are pure sulphur-yellow; a minute dusky costal spot, dark 
brown discocellular spot with white pupil, and six minute black marginal dots between the veins.

$b$. Secondaries below sulphur-yellow throughout, two additional brown spots, on the interno-median and second median interspaces.

c. Secondaries below flesh-pink with yellowish margins, the whole surface mottled with indistinct olive spots, a dusky longitudinal streak through the cell; other markings as in var. $a$, but less distinct.

$d$. Secondaries inclining to ferruginous excepting towards apex, where the ground-tint is yellow, a yellowish streak above a blackmottled dusky longitudinal streak through the cell: the whole remaining surface mottled with olive and black; other markings as in var. $b$, but larger.

In addition to the above modifications, the black border on the upper surface of the primaries varies both in width and length; but its inner edge is always more or less dentate-sinuated.

\section{Teracolus venustus, sp. $n$.}

o. Above like a small specimen of $T$. aurigineus, but with narrow external black borders to the wings, a smaller spot at the end of the discoidal cell of primaries, and the black band of secondaries terminating at third median branch; below it also differs in having the apex and outer border of primaries and ground-colour of secondaries sandy buff instead of sulphur-yellow. Expanse of wings 36 millim.

Kilima-njaro (F.J. Jackson).

Allied to the preceding is a species of which we have receired no less than nine specimens from Somali-land, but which, from an omission to examine them individually, I confounded with the T. chrysonome of Klug; I describe it as follows :-

\section{Teracolus helvolus, sp. $n$.}

Nearly allied to $T$. chrysonome, the wings a little shorter and stnaller; the indication of a band across the secondaries much more decided; the discal zigzag band of primaries below ending in a black spot; the apex and outer border of primaries and entire ground-colour of secondaries on the under surface flesh-pink instead of sulphur-yellow. Expanse of wings 33-35 millim.

$T$. chrysonome measures 40-44 millim. in expanse; it is a widerranging species than $T$. helvolus, which is probably restricted to Somali-land.

\section{Teracolus comptus, sp. 11 .}

Nearly allied to $T$. antigone, which we have in both sexes from Accra, but larger, the wings decidedly longer, the black external border of primaries narrower; the black spots of secondaries much smaller; the internal band on the male more or less prominent, more so than in our specimen of $T$ ' antigone, in both males before me; the orange apical patch of the male broader and not so red; the black rpical patch in the female connected by a line of black 
scales with the internal band, which is much darker than in $T$. antigone; the cell, however, is not suffused with grey at the base as in that species; costal band much blacker; marginal spots smaller towards anal angle. Expanse of wings 38 millim.

Kilima-njaro (F.J. Jackson).

Before proceeding to another genus $I$ think it will be useful to refer to two species described by Herr Aurivillius in the 'Öfversigt Kongl. Vetensk.-Akad. Forhandl.' for 1879, in a memoir on the Lepidoptera of Damara-land.

The first of these is described as Callosune deidamioides and is, I believe, only a slight variety of $C$. eveninus, which varies considerably in the very characters used for discriminating $C$. deidamioides.

The second is named $C$. damarensis; it answers perfectly to some of the male specimens of my T. ignifer, var., and I do not doubt its identity with that form; it may be a good species, but the points which separate it from typical $T$. ignifer are very slight, the principal distinction being the pinker tint of the under surface of the secondaries.

\section{Mylothris NarCissus, sp. $n$.}

Nearest to $M$. trimenia, of the same colours, but the primaries quite distinct in pattern, the base being broadly black (to the middle of the discoidal cell) in the male and dark brown in the female; the costal margin black; apical black border and marginal spots of male fully three times as broad as in $M$. trimenia; in the female there is a broad dark brown external border tapering on the costal margin, its inner edge acutely tridentate on the median branches and its posterior termination, obtusely pointed, extending one third towards the base ; first marginal black spot of secondaries enlarged in both sexes, but especially in the male, other spots smaller than in $\boldsymbol{M}$. trimenia: on the under surface the apex of primaries and entire surface of secondaries are sulphur-yellow in the male and chromeyellow in the female, not gamboge-yellow as in the S. African insect; there are also no black marginal spots on the primaries and those of the secondaries are smaller. Expanse of wings ot 53 millim., + 54 millim.

Forests of Tiveta (Hannington).

The costal margin of the primaries is noticeably shorter in this species than in $M$. trimenia.

Mr. Jackson obtained a species of Terias allied to T. chalcomiceta, or perhaps that species; it is not absolutely constant in pattern, and some examples differ so little from the common type of Aden that I am unwilling to separate it. As it has been suggested to me that $T$. chalcomiata is "only a variety" of $T$. hecabe, I may say once for all that the phrase is utterly unintelligible to me ; there is only one Terias (to my knowledge) in Aden, and it is about as unlike $\boldsymbol{T}$. hecabe as any two species of T'erias can well be. Undoubtedly we have the strongest evidence that there once was only one Terias and that all the species now existing are local races or climatic forms of 
that probably long extinct type; but to associate, as one, all the species or half the species now existing, is to hinder the study of the genus. Those Lepidopterists who, professing to believe in evolution, practically deny its existence, inasmuch as they associate nearly all allied forms under one specific name, are constantly getting into difficulties; so much perplexed are they as to whether they shall call a new form a "species" or a "variety," that they will even speak of it as "more or less synouymous" with something previously described.

\section{Herpenia iterata, sp. $\mathrm{n}$.}

Nearest to $H$. melanarge of Somali-land, but constantly considerably larger, the white marginal spots of secondaries larger, the subbasal black belt broader. Expanse of wings 55 millim.

Kilima-njaro (F. J. Jackson).

Although the distinction between this form and $H$. melanarge is chiefly one of size (the latter expanding only 44 millim.) the constancy of this character in my opinion constitutes it a separate species and entitles it to a name of its own.

Mr. Jackson obtained Nepheronia argia, the male in every respect identical with exanples from Sierra Leone, the female nearest to the variety named $N$. poppea, but differing above as follows :- the patch at base of primaries vermilion-red; the outer border narrower and enclosing a large white subapical spot; the secondaries with five somewhat diffused marginal dark brown spots.

I may be deemed inconsistent for not naming the foregoing form ; but as only one example has come to hand, and the fumales of $N$. argia are known to be extremely variable, I do not believe that I have anything before me but an individual sport (i.e. a variety).

Dr. Boisduval, after describing the yellow female under the name of Pieris idotea, concludes by saying-“Nous n'avons pas vu la femelle."

\section{Eronia dilatata, sp. n.}

Nearly allied to $E$. cleodora, the apical area of primaries above always marked with two and sometimes with three white spots; secondaries almost invariably with a broader external border, often twice the width of that of E. cleodora; below, the yellow patch on the apical area of primaries and the ground-colour of the secondaries are paler than in $\boldsymbol{E}$. cleodora, lemon-yellow instead of saffron; the outer border of secondaries is invariably much wider, and the other markings are comparatively shorter and broader than in the southern form. Expanse of wings 62-71 millim.

$\sigma^{*}$. Taveta, 2000-3000 feet, in dense forest (H. H. Johnston); $d$, ․ Forests of Taveta (Bishop Hannington); Kilima-njaro (F. J. Jackson).

As will be seen from the above description, the only satisfactory distinguishing characters in $E$. dilatata are the different yellow colour and much wider border to secondaries on the under surface; 
but after examination of a good series of specimens I have come to the conclusion that these characters are constant.

Mr. Jackson obtained three species of Papilio,-P. philonoë and $P$. constantinus of Ward and $P$. ophidicephalus of Oberthïr : the last mentioned does not differ from the southern type.

\section{H ES P E R I I D I.}

Hesperia keithloa and H. bixa were obtained; also Chatocneme cerymica, one or two obscure little species which have probably been named by Monsieur Mabille or Herr Plötz, and the following :-

\section{Plesioneura biseriata.}

Nearest to $P$. galenus, a little larger; primaries with the same pattern, but the spot on basal area smaller; secondaries with two distinct sinuous series of orange spots, the inner series consisting of seven spots, of which the second is large and diamond-shaped; the third and seventh reduced to mere points; outer series consisting of five decreasing spots, the first and largest bifid and touching the outer margin; fringe orange, divided by black lines at the extremities of the veins ; discoidal spot indistinct ; secondaries below paler than above, but similar in pattern ; in other respects this species agrees with $P$. galenus. Expanse of wings 43 millim.

Kilima-njaro ( $F$. J. Jackson).

\section{HETEROCERA.}

Aellopus hirundo appears to be the common Hawk-moth; Mr. Jackson brought home six or seven specimens, but unfortunately these and many others of his moths got more or less broken, owing to some beetles getting loose and rattling about amongst them: the following, however, fortunately came to hand in splendid condition.

\section{A R C TIIDA.}

\section{Charideine.}

11. Pompostola smaragdina, sp. $n$.

Wings blue-black, the basal fifth and the costal border to the end of the cell mottled with brilliant metallic emerald-green spots and dashes; two cuneiform spots, confluent behind, within the cell, the inner one metallic green, the outer one hyaline white, richly glossed with emerald-green; a quadrate green-glossed hyaline spot immediately beyond the cell; a long oblique tapering green-glossed hyaline streak from the median vein just below the double discoidal spot almost to the external angle; in some specimens, however, this streak is widely interrupted in the middle, leaving only two small spots; a subcostal metallic green streak, from the centre of which a transverse irregular green-glossed hyaline band runs almost to outer margin at about apical fourth; costal border of secondaries rufous brown; a small hyaline white subcostal spot, followed by a

Proc. Zool. Soc.-1888, No. VII. 
metallic emerald-green streak; an oblique cuneiform trifid greenglossed hyaline-white spot across the middle, two large patches almost filling the interno-median and the abdominal areoles, and a minute spot near outer margin on the second median interspace; thorax blue-black, frons and vertex of head metallic emerald-green; collar above with two large spots of metallic golden green, a triangular dorsal spot of the same colour; posterior half of patagia metallic fiery copper; metathorax and the two basal segments of abdomen metallic golden green: the two following segments deep brick-red edged with black ; remaining segments blue-black, banded in front with metallic emerald-green; primaries below purplish towards the base, otherwise nearly as above; secondaries with a broad metallic-yreen costal stripe from base to apex; pectus bronzebrown sprinkled with metallic-green scales; legs blackish brown, the coxæ of the first pair and the tibiæ of the other pairs with a large white spot; venter blue-black, with two unequal central white spots. Expanse of wings 32-41 millim.

Slopes of Kilima-njaro ( $F$. J. Jackson and Bistiop Hannington).

The examples collected by Bishop Hannington are smaller and have the markings on their wings smaller and narrower than in the type collected by Mr. Jackson.

LI T H O S I D E.

\section{Lepista limbata.}

Near to L. pandula, Boisd. (Dyphlebia trimenii, Feld.); larger, of a deeper orange-ochreous colour : the black border wider, that of primaries occupying two fifths instead of less than one third of the external area, its inner edge more oblique, that of secondaries about one third wider. Expanse of wings 24 millim.

Kilima-njaro ( $F$. J. Jackson).

We have $L$. pandula from Delagoa Bay.

Two interesting species of Chalcosiida collected by Mr. Jackson have been separately described. Of the Liparida one species, Aroa discalis, Walk., is in the collection; hitherto we have only received it from the Cape and Natal. Amongst the Noctuites Eurhipia bowkeri and Asymbata roseiventris, or species scarcely distinguishable from the latter, were obtained, as also the handsome but common Hypopyra capensis.

From the Proceedings of the Zoological Society of London, February 7, 1888.] 

Cume 1809. 



\section{$(375)$}

XIV. Synonymic notes on the moths of the earlier genera of Noctuites. By Arthur G. Butler, F.L.S., F.Z.S.

[Read June 5th, 1889.]

DuRing a recent re-arrangement of the genera Agrotis, Mamestra, and allies, I have discovered a considerable number of synonyms, which I now propose to reeord. In my re-arrangement $I$ have in the main followed the classification employed in A. R. Grote's 'Check List of North American Moths' of 1882, as being on the whole more natural than that of Lederer (adopted by Staudinger and Wocke); at the same time I have, to a certain extent, broken up the very heterogeneous group Agrotis, and, on the other hand, have amalgamated the homogeneous material separated under the names Mamestra, Apamea, Hadena, \&c. In some instances, as in the case of Triphana, I have adopted the generic name rather as representing a well-marked and easily recognised group than because it actually possesses any strictly generic value; but, as a rule, I have endeavoured to use only such names as appear to represent groups differing structurally from their nearest allies, though occasionally the structural distinctions are slight, and such as might be considered by some lepidopterists insufficient. It should, I think, always be borne in mind that the object of genera is to simplify as much as possible the study of nature, and therefore, that in the arrangement of such unwieldly genera as Agrotis, any single structural character ought to be considered sufficient, if it enables the student to break them up into groups of more manageable dimensions.

\section{Agrotis, Ochs.}

I have restricted this genus to species the males of which have either pectinated or serrated antennæ, the serrations terminating in short cilia-like pencils. The type of the genus is $A$. segetis.

TRANS. ENT. SOC. LOND. 1889.-PART IIJ. (OCT.) 
Synonyms to Agrotis.

1. Agrotis segetis, Gmel.

Agrotis marginalis, Walker, Lep. Het., x., p. 339, n. 77 (1856).

A. obliviosa, Walker, l.c., p. 340, n. 78 .

A. dividens, Walker, l.c., p. 342, n. 86 .

$A$. aversa, Walker, $l$. c., p. 345, n. 92.

A. correcta, Walker, l. c., n. 93.

A. repulsa, Walker, Suppl., 2, p. 696 (1865).

A. conspurcata, Walker, l. $c$.

A. certificata, Walker, l. c., p. 697.

Of the above synonyms, A. marginalis, obliviosa, and dividens are from South Africa; A. aversa, correcta, and repulsa from India; $A$. conspurcata from Ceylon; and A. certificata from Shanghai. Mr. Walker has selected chiefly the dark female specimens of the species for description; $A$. dividens, however, is a dwarfed pale female with pinched-in abdomen and male colouring; it is described as a male.

\section{Agrotis biconica.}

Agrotis biconica, Kollar in Hügel's Kaschmir, iv., p. 480 (1842-44).

A. exigua, Kollar, l. c., p. 481.

A. spiculifera, Guenée, Noct., i., p. 266, n. 425 (1852).

A. aristifera, Guenée, l.c., n. 426 .

A common and widely distributed Indian form, intermediate between $A$. segetis and $A$. munda. A. exigua is a name given to a starved specimen.

\section{Agrotis munda.}

Agrotis munda, Walker, Lep. Het., x., p. 348, n. 99 (1856).

A. basinotata, Walker, l. c., xv., p. 1686 (1858).

A. aneituma, Walker, Suppl., 2, p. 701 (1865).

A. turbulenta, Walker, l.c., 2, p. 703 .

A. injuncta, Walker, $l$. c.

A common Australian species, easily distinguished from $A$. segetis and biconica by the blackish apical patch on under surface of secondaries. 
moths of the earlier genera of Noctuites.

4. Agrotis interjectionis.

\& Agrotis interjectionis, Guenée, Noct., i., p. 281, n. 454 (1852).

\& A. orbicularis, Walker, Lep. Het., Suppl., 2, p. 700 (1865).

đ A. significans, Walker, l.c.

Java.

5. Agrotis corticea, Schiff.

Agrotis fraterna, Moore, Descr. Ind. Lep. Atk., ii., p. 116 (1882).

The Indian specimens differ in no respect from specimens in the Zeller series taken in Europe.

\section{Agrotis ignobilis.}

Mamestra ignobilis, Walker, Lep. Het., ix., p. 239, n. 39 (1856).

Agrotis rubrilinea, Walker, l.c., x., p. 351, n. 105 (1856).

A. recondita, Walker, l.c., n. 106.

A. dorsicinis, Walker, l.c., xv., p. 1701 (1858).

A slightly variable Australian species.

7. Agrotis subgothica, Haw.

Feltia ducens, Walker, Lep. Het., ix., p. 203, n. 1 (1856).

An example from Orilla.

\section{Agrotis jaculifera, Guén.}

The A. tricosa of Lintner is typical A. jaculifera, and $A$. herilis appears to me to be a very slight variety only distinguishable by its greyer coloration and the grey instead of dull whitish "orbicular" spot of primaries; at the same time, as we have a good series of the latter, and its specific identity with $A$. jaculifera is unproved, I have retained it as a distinct species in the collection.

Owing to the difficulty of collating the many scattered references to the descriptions of North American species, and the time which would be occupied in so doing, I cannot attempt here to look them up; a mere quotation 
of the synonyms will be enough for those who make a special study of the N. American fauna.

\section{Agrotis vancouverensis, Grote.}

The $A$. semiclarata of the same author appears to me to be the female of $A$. vancouverensis.

\section{Agrotis venerabilis.}

Agrotis venerabilis, Walker, Lep. Het., x., p. 328, n. 49 (1856).

A. incallida, Walker, l.c., p. 330, n. 52.

A fairly common N. American species, near to $A$. volubilis of Harris.

\section{Agrotis annexa, Treit.}

Agrotis anteposita, Guenée, Noct., i., p. 278, n. 449 (1852).

A. decernens, Walker, Lep. Het., x., p. 333, n. 60 (1856).

A very common New World species.

12. Agrotis bipars.

o Agrotis bipars, Walker, Lep. Het., x., p. 334, n. 62 (1856).

๙ 우 A. consueta, Walker, l.c., n. 63 .

The types were all taken by Dyson in Venezuela.

\section{Agrotis bilitura.}

Agrotis bilitura, Guenée, Noct., i., p. 285, n. 467 (1852).

A. deprivata, Walker, Lep. Het., xi., p. 739 (1857).

A Chilian species, the males of which have the serration of the antennæ less pronounced than in any of this group of New World forms.

14. Agrotis hostilis.

Agrotis hostilis, Walker, Lep. Het., xi., p. 737 (1857). A. consueta, Walker, l.c., p. 738.

Graphiphora sobria, Walker, l.c., p. 744. 
Agrotis incommoda, Walker, l.c., Suppl., 2, p. 692 (1865).

The types are from New Grenada and Venezuela.

15. Agrotis spissa.

Agrotis spissa, Guenée, Noct., i., p. 261, n. 415 (1852).

An example of this species in the Grote collection is labelled as A. cochranii of Riley; the latter, however, though nearly allied to $A$. spissa, is possibly distinct; it is much darker.

16. Agrotis admirationis.

Agrotis admirationis, Guenée, Ent. Month. Mag., v., p. 38 (1868).

? Chersotis inconspicua, Butler, Cist. Ent., ii., p. 545, n. 14 (1880).

Var. Chersotis sericea, Butler, l.c., p. 490, n. 9 (1879). New Zealand.

If our examples of $A$.admirationis are rightly identified I think the above must be considered synonyms; A. sericea is the more distinct form, the markings of the primaries being almost wholly absent, but it may well be a variety.

17. Agrotis moderata.

Agrotis? moderata, Walker, Lep. Het., Suppl., 2, p. 705 (1865).

Spalotis inconstans, Butler, Cist. Ent., ii., p. 545 (1880).

New Zealand.

We now possess nine examples of this species, and I find it impossible to separate the above, which varies not a little.

18. Agrotis insignata.

Agrotis insignata, Walker, Lep. Het., x., p. 330, n. 53 (1856).

A. tritici (part), Guenée, Noct., i., p. 288, n. 471 (1852). Mamestra declarata, Walker, Lep. Het., Suppl., 2, p. 663 (1865).

Agrotis campestris, Grote (vide Check List, p. 25, n. 215).

A common N. American species allied to A. tritici. TRANS. ENT. SOC. LOND. 1889. PART III. (oct.) 2 D 


\section{Agrotis divergens.}

Agrotis divergens, Walker, Lep. Het., x., p. 327, n. 46 (1856).

Agrotis versipellis of Grote is indistinguishable from this species.

20. Agrotis spina.

Agrotis spina, Guenée, Noct., i., p. 269, n. 433 (1856). A. capularis, Guenée, l.c., p. 271, n. 437.

Mamestra tenebrosa, Walker, Lep. Het., Suppl., 2, p. 669 (1865).

A common Australian species.

The genus Pachnobia appears to me to be a mere group of Agrotis; I restrict it to P. carnea, rubricosa, imperita, geniculata, and salicarum.

\section{Peridroma, Hübn.}

Differs from Agrotis in the finely ciliated (neither pectinated nor serrated) antennæ of the males. Type, P. saucia (ypsilon, Rott.).

\section{Peridroma ypsilon, Rott.}

Noctua saucia, Hübner, Samml. Europ. Schmett., fig. 378.

Agrotis differens, Walker, Lep. Het., x., p. 336, n. 67 (1856).

A. ambrosioides (Morrison), Walker, Lep. Het., xi., p. 738 (1857).

Var. Spelotis stictica, Blanchard, in Gay's 'Fauna Chilena,' vii., p. 73, n. 1; pl. 6, fig. 8 (1854).

Var. Agrotis impacta, Walker, Lep. Het., x., p. 337, n. 71 (1856).

A. intecta, Walker, l.c., p. 338, n. 72.

An example in the Grote collection corresponding with the variety $A$. impacta is labelled "Agrotis turris"; the variety $A$. stictica is the most extreme variegated form of the species.

Tiracola, Moore.

A strong-bodied Sphingiform genus, the males of which have simple antennæ. 
Tiracola plagiata.

Agrotis plagiata, Walker, Lep. Het., xi., p. 740 (1857). A. plagifera, Walker, l.c., p. 741.

Var. Agrotis spectabilis, Walker, l.c., Suppl., 2, p. 704 (1865).

Java, Borneo, Ceylon, Canara, Darjiling, and Moreton Bay.

The Canara specimens are labelled "sphingiformis," apparently a MS. name proposed by Adam White; the variety from Moreton Bay is simply a dark-coloured example. Mr. Druce has the same variety from Mexico and Rio Janeiro.

The genus Spelotis (type S. ravida) consists of a few oblong-winged species, the males of which have simple antennæ; I think it doubtful whether this group should be kept separate from the Noctua of authors, which it greatly resembles.

Spæzotis, Boisd.

Spalotis ravida, Schiff.

Noctua clandestina, Harris, Ins. inj. veg., 3rd ed., p. 448 (1862); 1st ed. (1841).

Mamestra unicolor, Walker, Lep. Het., ix., p. 233 (1856).

Graphiphora valida, Walker, l.c., Suppl., 3, p. 711 (1865).

G. caliginea, Butler, Ann. Nat. Hist., 5, vol. i., p. 165 (1878).

A somewhat variable common and widely-distributed species; the European examples are, as a rule, smaller than those from other parts of the world. In the Grote collection I found a female of this species labelled as "A. pastoralis, Grote."

Most of the species hitherto placed in Spalotis will have to be removed to Chera.

\section{Chera, Hübn.}

Chera birivia, Hüb.

I cannot distinguish the Agrotis dolis of Grote from this species. 
382 Mr. A. G. Butler's synonymic notes on the

\section{Graphiphora, Ochs.}

This genus, of which $G$. augur is type, must be restricted to a small group of broad-winged species; it will include G. sierre, augur, haruspica, and major. G. haruspica, though very closely allied to G. augur, differs in being constantly much darker and usually larger.

Amathes, Hübn. (Noctua, auct.).

The type of this genus is A. baja ; Spelotis, Boisd., may have to be sunk as a synonym of it.

Amathes, Hübn.

1. Amathes phyllophora, Grote.

Agrotis phyllophora, variata, varix, and alternata are all colour variations of one species; under $A$. phyllophora there are specimens indistinguishable, even in colour, from others labelled "A. alternata" by Grote, whilst all intermediate gradations exist between the reddest $A$. phyllophora and the blackest $A$. alternata.

\section{Amathes jucunda, Walk.}

Graphiphora jucunda, Walker, Lep. Het., x., p. 399, n. 27 (1856).

This is the Agrotis conflua of Grote's collection, but not of Europe.

3. Amathes comma.

Mamestra comma, Walker, Lep. Het., ix., p. 239, n. 40 (1856).

Graphiphora implexa, Walker, l.c., x., p. 405, n. 42 (1856).

Hadena plusiata, Walker, l.c., Suppl., 3, p. 742 (1865). Xylina collaris, Walker, $l . c .$, p. 752 .

Nitocris bicomma, Guenée, Ent. Month. Mag., v., p. 4 (1868).

A common New Zealand form, the sexes of which are very dissimilar.

4. Amathes atra.

i Agrotis atra, Guenée, Noct., i., p. 272, n. 438 (1852).

ð. A. hydracioides, Guenée, l. c. 
moths of the earlier genera of Noctuites.

Graphiphora reclusa, Walker, Lep. Het., x., p. 403 (1856).

G. instipata, part Walker, l.c., p. 404.

q var. Agrotis testaceicollis, Guenée, Noct., i., p. 273 (1852).

Mamestra lucifera, Walker, Lep. Het., Suppl., 2, p. 668 (1865).

The Australian representative of the preceding species.

5. Amathes instipata.

Graphiphora instipata, Walker, Lep. Het., x., p. 404, n. $40(1856)$.

Hadena congregata, Walker, l.c., xi., p. 598, n. 94 (1857).

Orthosia? lunifera, Walker, l.c., p. 747.

An Australian species allied to the preceding.

6. Amathes velata.

Graphiphora velata, Walker, Lep. Het., Suppl., 3, p. 710 (1865).

Agrotis cupida of Grote is this species; A. brunneipennis is a brownish variety, and $A$. placida a variety of the female, in which the hind wings are dark brown.

7. Amathes parentalis.

Agrotis parentalis, Grote, is a species nearly allied to A. cuprea of Europe, of which A. decipiens is probably only a dark variety; we have one pale example of A. cuprea from Washington Territory.

8. Amathes bicarnea.

Noctua bicarnea, Guenée, Noct., i., p. 329 , n. 546 (1856).

Mamestra plagiata, Walker, Lep. Het., Suppl., 2, p. 664 (1865).

A common North American species.

Ochropleura, Hübn.

This is a mere section of the preceding genus, in which the secondaries are shining white. 
Ochropleura plecta.

Phalena-Noctua plecta, Linneus, Syst. Nat., p. 2851, n. 157.

Ochropleura vicaria, Walker, Lep. Het., x., p. 409, n. 7 (1856).

O. costalis, Moore, P.Z.S., 1867, p. 56.

I can discover no difference whatever between European, African, North American, Japanese, or Indian examples of this species.

\section{Anyrus, Grote.}

This genus seems to me much more like Pharetra (which I refer to the Arctiida) than to the Noctuida, but for the present I have left it where Grote placed it.

Anytus privatus.

Polia privata, Walker, Lep. Het., xi., p. 521, n. 19 (1857).

This is the Xylina sculpta of Grote from N. America.

Eucoptocnemis, Grote.

A small genus of broad-winged species with deeply pectinated male antennæ.

Eucoptocnemis fimbriaris.

Heliophobus fimbriaris, Guenée, Noct., i., p. 172, n. 271 (1852).

Graphiphora obvia, Walker, Lep. Het., xv., p. 1707 (1858).

N. America.

Tetrapyraia, Walk.

Tetrapyrgia graphiphorides.

Tetrapyrgia graphiphorides, Walker, Lep. Het., Suppl., 3, p. 712 (1865).

Elegarda summa, Walker, l.c., p. 713.

Tasmania.

The first type is a worn example. The antennæ of males in this genus are extremely long, tapering, and pectinated strongly to near the tips, which are naked. 
Tetrapyrgia pectinata.

Spalotis pectinata, Walker, Lep. Het., Suppl., 3, p. 707 (1865).

Elegarda orthosioides, Walker, l.c., p. 712.

Moreton Bay.

A rather variable species.

Semiophora, Steph.

Very similar to Amathes (Graphiphora, auct.), but the males with antennæ strongly pectinated, as in the genus Eucoptocnemis; several of the species hitherto referred to Agrotis, Graphiphora, and Taniocampa belong rightly to this genus.

Semiophora elimata.

Graphiphora elimata, Guenée, Noct., i., p. 333, n. 556 (1852).

The Agrotis dilucida of Morrison is indistinguishable from this species.

Mamestra, Ochs.

The bulk of the species hitherto referred to Apamea and Hadena are structurally identical with Mamestra; the same pattern also runs through the species.*

1. Mamestra dissimilis, Knoch.

I cannot distinguish the $M$. atlantica of Grote from this species.

2. Mamestra thalassina, Hüfn.

M. nevada of Grote is this species.

3. Mamestra cristifera.

Acronycta cristifera, Walker, Lep. Het., xv., p. 1654 (1858).

This is the Mamestra lubens of Grote.

* The lashed or smooth eyes of species otherwise closely allied do not in my opinion constitute a safe generic character. 
386 Mr. A. G. Butler's synonymic notes on the

4. Mamestra gemina var. remissa.

Noctua remissa, Hübner, Schmett. Eur. Noct., pl. 90, fig. 423.

Xylophasia indocilis, Walker, Lep. Het., ix., p. 178, n. 19 (1856).

N. America.

5. Mamestra modica.

Apamea modica, Guenée, Noct., i., p. 207, n. 327 (1856).

Celana subcedens, Walker, Lep. Het., x., p. 204, n. 11 (1856).

New York.

6. Mamestra instructa.

\& Hadena instructa, Walker, Lep. Het., Suppl., 3, p. 733 (1865).

ð H. rubescens, Walker, l.c.

Cape (Trimen).

7. Mamestra egens.

Celana egens, Walker, Lep. Het., x., p. 263, n. 10 (1856).

Hadena? stricta, Walker, Lep. Het., Suppl., 3, p. 728 (1865).

This is the Mamestra cinnabarina, var. ferrea, of Grote, which it will supersede.

8. Mamestra consanguis.

Hadena consanguis, Guenée, Noct., ii., p. 97, n. 810 (1852).

Apamea undicilia, Walker, Lep. Het., ix., p. 251, n. 18 (1856).

A common Indian species.

9. Mamestra renisigna.

Celana renisigna, Walker, Lep. Het., x., p. 267, n. 20 (1856).

Hadena depulsa, Walker, l.c., xi., p. 590, n. 75 (1857).

H. ficita, Walker, l. c., Suppl., 3, p. 734 (1865).

$H$. contracta, Walker, $l . c .$, p. 735 .

Cape of Good Hope. 
10. Mamestra thoracica.

o Mamestra thoracica, Walker, Lep. Het., xv., p. 1684 (1858).

o Hadena languida, Walker, l.c., p. 1728.

Natal (Gueinzius).

As I continue the arrangement of the general collection of Noctuites, it is certain that numerous other synonyms will be discovered. As regards tropical New World forms, it is certain that I shall overlook many, from lack of sufficient material; but probably most of these will be cleared up by Mr. Druce, whose series of Central and South American moths is so ample that in some variable genera the most astonishingly dissimilar forms are clearly seen to be mere sports. 



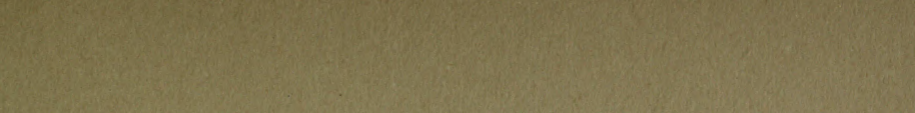

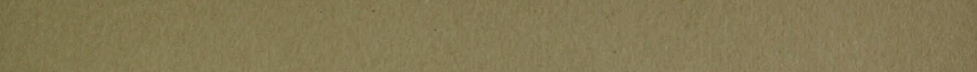

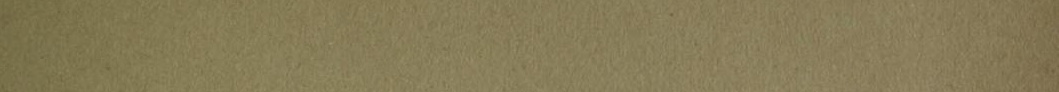

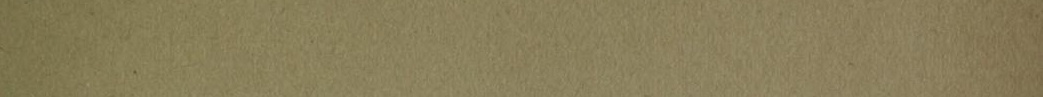



[From the Annals and Magazine of Natulal History for July 1890.$]$

Notes on the Genus Dyschorista, Led., a small Group of Moths allied to Orthosia. By A. G. Butrer.

The genus Dyschorista was founded for the reception of tw European species, $D$. suspecta, Hübn., and $D$. ypsilon $=$ fiss $i$ puncta, Hew. (see Lederer, Noct. p. 143, gen. 82).

Accepting $D$. suspecta as type of the genus, it will be necessary to include the bulk of the forms referred by M. Guénée to his previously characterized genus Orthodes.

Orthodes, Guénée, was described in the first volume of the 'Noctuélites,' p. 371, no type being indicated; but Guénée selected two of the species, $O$. $t$-nigrum and $O$.curvirena (both Brazilian), for illustration. In the description of the species of his second group Guénée pointed out that $O$. curvirena differed structurally from the remainder of the genus:"L'une d'elles (Curvirena) a les palpes particulièrement ascendants et allongés." He thus restricted the identification of his type to $0 . t$-nigrum, the first species of his first group.

In the Museum collection we have an example of $O \cdot t$-nigrum, and, as may be seen from the figure in the 'Noctuelites,' it has no connexion whatever with the remainder of the species, but is in fact far more closely allied to Leucania; fortunately the remaining species correspond with $D$. suspecta in size, pattern, coloration, the ascending palpi, simple antennæ, and heavily tufted anal decorations of the male.

In his 'Check-list of North-American Moths' for 1882 Grote rightly reduced the number of M. Guénée's NorthAmerican species, Orthodes nimia and candens being sunk as 
synonyms of $O$. cynica, of which they are in fact slight varieties; $O$. infirma, however, is a Brazilian species, and must be expunged from the North-American fauna, the form described by M. Guénée as var. A being, as he supposed, a distinct species.

In typical $Q$. infirma the secondaries of the male are creamy white-"Ailes infer. d'un blanc-jaunâtre"-whereas in the northern form they are of the same glossy brownish grey as in the female. In the Brazilian insect the inner line of the central area of primaries is more oblique and much more irregular and the outer line more distinctly sinuated between the nervures; both of these lines and the edges of the discoidal spots which they enclose are much less prominent than in the northern form; but, as M. Guénée says, the subterminal line is clearer, at any rate it is so in the female; the marginal spots are very indistinct, and are thus overlooked in the original description of the Brazilian form; but in that of var. A the pale zigzag line which shows them up in the northern form is noted :- " Un feston terminal clair trèsmarque." I propose to give the North-American species the new designation of Dyschorista crenulata.

Four closely allied Brazilian species are in the collection, all differing more or less in the clothing of the under surface of the primaries, the tufting of the anal extremity in the males, or the palpi; one of these is typical $O$. infirma, a second may be $O$. rubor, but the discoidal spots are bordered by a pale line, whereas in Guénée's type (a female) they were not; a third I am unable to recognize from any of the descriptions; it is a male with closed anal claspers, giving it the aspect of a female; the costa of the primaries is distinctly arched towards the base; the under surface of these wings almost wholly covered with dense rough hair, which extends also to the basicostal area of secondaries; the coloration and general pattern is that of Dyschorista crenulata, but the "orbicular" spot is rhomboidal, the two outlines of the central area are indistinct and much more parallel, and the pale crenulated submarginal line is wanting; the pectus and femora are also much more hairy. I propose to call this Dyschorista lanaris. The fourth species of the same group is O. curvirena-a most remarkable insect, in which the palpi are curved upwards like those of a Deltoid and the anal tufts, when fully expanded, are seen to be enormously developed. The genus seems to abound in extraordinary ornamentation; in D. melanogaster M. Guénée says, "Abdomen noirattre en dessus, garni latéralement de poils carnés, à l'extrémité d'une brosse jaunâtre," which calm description hardly prepares one for the large expanded rose-coloured brushes of the moth. 


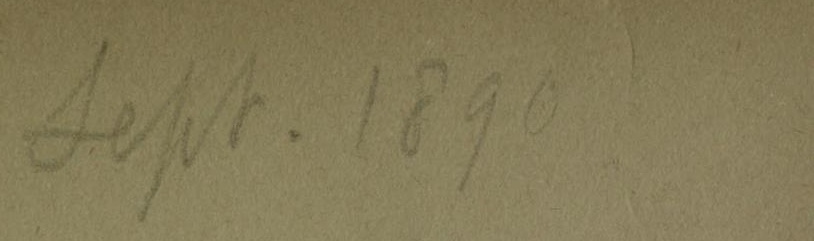

1890 

XX. Further notes on the synonymy of the genera of Noctuites. By Arthur G. Butler, F.L.S., F.Z.S., \&c.

[Read September 3rd, 1890.]

To some of the groups already treated of, I have a few additional notes to record; I shall therefore take them in the order in which they now stand in the Museum cabinets.

\section{CYMATOPHORIDE.}

Prometopus, Guén.

1. Prometopus inassueta.

Prometopus inassueta, Guenée, Noct., i., p. 38, n. 42 (1852).

Bryophila dorsivaria, Walk., Lep. Het., 15, p. 1648 (1858).

Australia and Tasmania.

M. Guenée placed this genus in his heterogeneous family Bombycoida; it is, however, allied to Cymatophora.

\section{NOCTUID正.}

Ochrople URA, Hübn.

In the Grote collection I found an example of $O$. plecta, which is labelled, probably in error, "Valeria grotei, Morr."

It is a very remarkable thing that Ochropleura, a genus founded by one of Mr. Scudder's favourite authors, is amongst the many lepidopterous genera omitted from the 'Nomenclator Zoologicus.'

Mentaxya, Hübn.*

Eugrapha, Hübner = Ariathisa, Walk.

1. Mentaxya amatura.

Agrotis amatura, Walker, Lep. Het., 15, p. 1700 (1858).

* This genus is extremely close to Anicla, Grote, which may have to be amalgamated with it.

TRANS. ENT. SOC. LOND. 1890.-PART IV. (DEC.) $2 \mathrm{x}$ 
Port Natal.

This species, in the Zeller collection, is labelled "Agrotis trisema, Z.," but I do not know whether he described it. Walker incorrectly associated two examples with two of an apparently unnamed species as $A$. albifrons, Hübn., which, however, is distinct.

\section{2l Mentaxya rimosa.}

Agrotis rimosa, Guenée, Noct., i., p. 277, n. 446 (1852). A. varia, Walker, Lep. Het., Suppl., 2, p. 694 (1865). Cape of Good Hope.

\section{Mentaxya muscosa.}

Mentaxya muscosa, Hübner, Zutr. Exot. Schmett., 10, 414, figs. $827,828$.

Diphtera cumulata, Walker, Lep. Het., Suppl., 2, p. 613 (1865).

Cape Town.

4. Mentaxya furcifera.

Agrotis furcifera. Walker, Lep. Het., 15, p. 1699 (1858).

United States.

This is A. brocha, Morrison. I do not know which name has priority.

ANICLA, Grote.

1. Anicla incivis.

Agrotis incivis, Guenée, Noct., i., p. 274, n. 441 (1852). United States to Brazil.

This is proved, by a comparison of the type-specimens, to be A. alabame, Grote. Prodenia pauper, Butl., described from a female received from Jamaica, is only a dwarfed form of the same species.

2. Anicla ignicans.

Agrotis ignicans, Guenée, Noct., i., p. 274, n. 440 (1852).

A. prodenoides, Walker, Lep. Het., 10, p. 354, n. 113 (1856).

S. America generally. 
In the species of Anicla the secondaries are white, as in most of the species of Mentaxya, but they are more opaline and less thickly scaled.

\section{Xylophasia, Stephens.}

I am unable to see any reason for ignoring this very natural group of moths, the bulk of which can be distinguished at a glance by the character of their markings ; they doubtless only form a subgroup of Mamestra, so far as structure goes, but it is convenient to keep them separate.

\section{Xylophasia rurea.}

Noctua rurea, Fabricius, Sp. Ins., ii., p. 240.

Europe and United States.

I can discover no characters by which to distinguish $X$. vultuosa, Grote, from this species.

\section{Xylophasia lignicolora.}

Xylophasia lignicolora, Guenee, Noct., i., p. 140, n. 221 (1852).

United States.

X. quanita, Grote, only differs from X. lignicolora in its slightly paler colouring, and $X$. auranticolor only appears to be a darker form of the same.

\section{Xylophasia cariosa.}

, Xylophasia cariosa, Guenée, Noct., i., p. 144, n. 232 (1852).

\section{United States.}

Hadena idonea of Grote is the male of this species ; the females labelled $H$. cariosa in the Grote collection do not agree with Guenée's type, and, in my opinion, represent a distinct and altogether a finer suecies.

It seems to be generally supposed, in the States, that the whole of M. Guenée's types are in the possession of M. Oberthür. An examination of the descriptions in the three volumes of the 'Noctuélites,' or, indeed, of any of the volumes of the 'Histoire Naturelle' (Lépidoptères) will show that nearly the whole of the N. American species were described from specimens lent to the author 
by Mr. Doubleday, and many of the East Indian species from specimens in the Museum of the E. I. Company. All these types, labelled by Guenee himself, are in the British Museum collection.

\section{Alibama, Moeschl.}

1. Alibama punctirena.

Hadena punctirena, Walker, Lep. Het., xi., p. 586, n. 64 (1857).

H. terens, Walker, l.c., n. 65 (1857).

St. Domingo, Venezuela, Guadaloupe. Coll. B. M.

This species appears to me to be better placed next to Dipterygia than elsewhere.

\section{AxyLIA, Hübn.}

\section{Axylia eridania.}

Phalana eridania, Cramer, Pap. Exot., iv., p. exxxiii., fig. F (1882).

Leucania externa, Walker, Lep. Het., 9, p. 114, n. 85 (1856).

Prodenia strigifera, Walker, l.c., 15, p. 1678 (1858).

South America.

The species regarded as the male by Cramer must bear the name.

Antachara, Walk.

Barely separable from the preceding genus. Associated with Xylophasia by M. Guenée.

\section{Antachara diminuta.}

Xylophasia diminuta, Guenée, Noct., i., p. 141, n. 223 (1852).

Antachara rotundata, Walker, Lep. Het., 15, p. 1741, n. 1 (1858).

Laphygma lignigera, Walker, l.c , Suppl, 2, p. 650 (1865).

Brazil.

$X$. denterna of Guenée is a species of this group : we have it from Rio Janeiro, 


\section{Antachara phytolacca.}

Phalena phytolacce, Smith Abbot, Lep. Ins. Georgia, ii., p. 193, pl. 97.

Xylina inquieta, Walker, Lep. Het., xi., p. 632, n. 22 (1857).

Prodenia ignobilis, Butler, Proc. Zool. Soc., 1878, p. 485.

North and South America.

This species varies in tint and in the prominence or the reverse of the black stigma at the end of the cell of primaries.

\section{Antachara albula.}

Xylina albula, Walker, Lep. Het., xi., p. 629, n. 16 (1857).

Laphygma orbicularis, Walker, l.c., p. 719.

St. Domingo, Honduras, Callao.

Allied to the preceding, though clearly a distinct species.

\section{Morrisonia, Grote.}

\section{Morrisonia ewingii.}

Noctua (Xylophasia?) ewingii, Westwood, Proc. Ent. Soc. Lond., ii., p. lv., pl. xx., fig. 1 (1837).

Cloantha composita, Guenée, Noct., ii., p. 114, n. 832 (1852).

Leucania dentigera, Butler, Cist. Ent., ii., p. 542 (1880). Australia, Tasmania, New Zealand, United States.

The last-mentioned locality is based upon a specimen in the Grote collection, undoubtedly of this species, labelled "Morrisonia peracuta, Morr." The species will probably be found to have a far wider geographical range than has been supposed: Walker made the astonishing blunder of identifying it with Drymonia dimidiata, H.-Sch.

\section{Auchurs, Guén.}

\section{Auchmis intermedia.}

Cloantha intermedia, Bremer, Lep. Ost.-Sibiriens, p. 53, tab. v., fig. 13 (1864).

Auchmis sikkimensis, Moore, Proc. Zool. Soc., 1867, p. 49, pl. vi., fig. 15.

India, Japan, South Africa. 


\section{LEUCANIA, Ochs.}

\section{Leucania l-album.}

Phalana-Noctua l-album, Linnæus, Syst. Nat., xii., p. 850.

Leucania bistrigata, Moore, Proc. Zool. Soc., 1881, p. 334 .

L. penicillata, Moore, l. c., p. 335.

Europe and India.

I have elsewhere pointed out that the slight characters on which the Indian species were based are very inconstant.

With $L$. insueta of Guenée, Walker associated four specimens of $L$. adonea.

\section{Leucania albilinea.}

Leucania albilinea, Hübner, Zutr. Exot. Schmett., p. 25, n. 169 , figs. 337,338 .

L. diffusa, Walker, Lep. Het., ix., p. 94, n. 35 (1856).

L. moderata, Walker, l. c., p. 114, n. 86 (1856).

Heliophila harveyi, Grote (see Check List, p. 30, n. 619). Leucania chilensis, Butler, Trans. Ent. Soc. Lond., 1882, p. 115, n. 4.

North and South America.

\section{Leucania humidicola.}

Leucania humidicola, Guenée, Noct., i., p. 90, n. 137 (1852).

L. extenuata, Guenée, l.c., n. 138.

L. dorsalis, Walker, Lep. Het., ix., p. 98, n. 43 (1856).

S. America.

I. humidicola is slightly paler than $L$. extenuata, but is undoubtedly the same species.

\section{Leucania loreyi.}

Leucania loreyi, Duponchel, Lep. France, vii., 1, p. 81 ; pl. 105, fig. 7 (1827).

L. collecta, Walker, Lep. Het., ix., p. 105, n. 63 (1856).

L. thoracica, Walker, l.c., p. 106, n. 68 (1856).

L. denotata, Walker, l. c., p. 107, n. 70 (1856).

Europe, Japan, India. 


\section{Leucania percussa.}

Leucania percussa, Butler, Proc. Zool. Soc., 1880, p. 674, n. 55 .

L. insularis, Butler, l.c., n. 56.

Formosa.

I believe these two must be slightly different forms of the same species; in any case $L$. insularis is much rubbed, and ought not to have been described.

\section{Leucania multilinea.}

Leucania multilinea, Walker, Lep. Het., ix., p. 97, n. 41 (1856).

Canada.

This is the species described by Grote as L. lapidaria, Grote: it is quite distinct from $L$. commoides, under which Grote gives "L. multilinea, Walk., in litt.," as a synonym.

\section{Leucania phragmitidicola.}

Leucania phragmitidicola, Guenée, Noct., i., p. 89, n. 136 (1852).

United States.

This species is quite distinct from the Haytian insect, identified with it by Walker, being very closely allied to the preceding, L. multilinea: it was correctly identified by Grote.

\section{Leucania amens.}

Leucania amens, Guenée, Noct., i., p. 88, n. 133 (1852). South Africa.

Probably only a pale form (the prevalent one) of $L$. torrentium, Guén.; the differences are slight, all the markings being alike.

9. Leucania exterior.

Leucania exterior, Walker, Lep. Het., ix., p. 106, n. 66 (1856).

L. designata, Walker, l.c., p. 107, n. 69 (1856).

India.

Both of the types are now in the Museum Collection, and prove to be inseparable as species. 
"Leucania" disjuncta, Walker, is an Agrotis; L. propria and $L$. semivittata must be transferred to Ommatostola.

10. Leucania extincta.

Leucania extincta, Guenée, Noct., i., p. 79, n. 107 (1852).

United States.

This is proved, by a comparison of the types, to be the Heliophila ligata of Grote.

\section{Leucania insueta.}

Leucania insueta, Guenée, Noct., i., p. 81, n. 113 (1852).

United States.

Allied to $L$. comma. The type only differs from that of $L$. adonea, Grote, in the less distinctly whitish costal border and veins of primaries : it is quite possible that they may prove to be forms of the same species, but I 'would always rather err on the side of allowing too many species to stand rather than too few ; it is always easy to put things together, but it often requires careful study to discriminate between closely-allied species.

\section{Leucania linita.}

Leucania linita, Guenée, Noct., i., p. 81, n. 114 (1852). L. insecuta, Walker, Lep. Het., Suppl., 2, p. 625 (1865).

L. intermissa, Walker, l. c., p. 626.

United States and Shanghai.

This is also identical with L. amygdalina, Harvey. The Shanghai specimens are indistinguishable from the American. I have already pointed out (Trans. Ent. Soc. Lond., 1882, p. 113) that $L$. decolorata of Blanchard is only a pale form of $L$. impuncta, Guén.

"L. pallens" of the United States agrees absolutely with the European L. straminea. The two forms have practically the same characters, and if received from any extra-European locality would never have been considered distinct ; indeed, it is possible to find examples which cannot with certainty be referred to one form 
rather than the other. L. straminea differs chiefly in the generally more prominent pale longitudinal streak above the median vein of the primaries, and the betterdefined black or dark markings. Not having bred both from the egg, I keep them separate in the collection.

The $L$. juncicola of Walker is not the species so named by M. Guenée, but is the L. adjusta of Grote. The true L. juncicola seems to be very closely allied to, if distinct from, $L$. scirpicola.

In the Index to 'Illustrations of Typical LepidopteraHeterocera,' I inadvertently placed L. griseifascia, Moore, as a synonym of $L$. commoides; it really is a dark form of L. percisa (Proc. Zool. Soc., 1888, p. 410).

The following is a very variable species, which has received many names :-

13. Leucania unipuncta.

Noctua unipuncta, Haworth, Lep. Brit., p. 174, n. 37 (1810).

Typical form. United States, Chili, New Zealand, Azores. Coll. B. M.

This is a large reddish form of the species in which the white dot on the primaries is very prominent. I have seen no undoubted European examples of the species, and the few specimens which may have been obtained were probably accidentally imported.

Var. saccharivora.

Leucania saccharivora, Butler, Trans. Ent. Soc. Lond., 1882, p. 115.

Chili, India, and New Zealand. Coll. B. M.

Smaller than the typical form, and of a brighter reddish colour; the white spot obsolete.

Var. antica.

Leucania antica, Walker, Lep. Het., ix., p. 100, n 52 (1852).

L. adusta, Moore, Proc. Zool. Soc., 1881, p. 335.

Western coast of America, Venezuela, Darjiling. Coll. B. M. 
About the same size as the preceding variety, but much paler, the primaries being pale testaceous, with ill-defined dusky markings, and the secondaries almost white, with more or less defined dusky border, darkest towards apex. The Indian examples show the dusky border distinctly as a broad subapical patch, varying in intensity in different individuals; one of the examples from Venezuela has a similar though less prominent patch.

\section{Var. trifolii.}

Leucania trifolii, Butler, Trans. Ent. Soc. Lond., 1882, p. 114.

Sao Paulo, Chili, Canada, Japan, Java, N.W. India, New Zealand, and Flores. Coll. B. M.

Altogether a greyer form, with prominent pale discoidal spots, well-defined dark oblique apical streak, and dusky secondaries.

Var. extranea.

Leucania extranea, Guenée, Noct., i., p. 77, n. 104 (1852).

United States, “Europe," Darjiling, Azores, Flores. Coll. B. M.

A darker form than the preceding, and generally larger.

Var. convecta.

Leucania convecta, Walker, Lep. Het., xi., p. 711 (1857).

Moreton Bay. Coll. B. M.

The primaries almost uniformly greyish, with testaceous reflections; the white dot almost lost in a blackish spot at the end of the cell; the secondaries whitish, with dusky veins and border somewhat as in the darkest form of var. antica.

Var. separata.

Leucania separata, Walker, Lep. Het., Suppl., ii., p. 626 (1865).

Japan, Shanghai, N. W. India, Goya, Chili, Kansas. Coll. B. M.

Scarcely separable from the preceding; the specimens 
have a washed-out, faded appearance; the primaries pale testaceous, with indistinct markings; the secondaries greyish white, with dusky veins and borders.

I have not the least doubt that the whole of the above forms are mere variations of one widely-distributed species; at the same time it is doubtful whether the whole of the forms occur together, as, in a long series, Mr. Edmonds only had the two varieties, L. trifolii and saccharivora, whilst the typical form, received subsequently from Talcahuano, is only like a duller, darker specimen of the latter variety: most of the varieties occur in N. Western India, but I have not seen typical L. unipuncta, var. antica, or var. convecta from there.

Hyphilare, Hübn.

This is the Mythimna of Walker, slightly modified : it will include $H$. albipuncta, lithargyria, rudis, albicosta, fraterna, rufipennis, placida, pseudargyria, singularis, formosana, turca, grandis and divergens, and perhaps obusta.

\section{Hyphilare pseudargyria.}

Leucania pseudargyria, Guenée, Noct., i., p. 74, n. 94 (1852).

\section{United States.}

The type of this species agrees exactly with the var. callida of Grote: in the Grote collection this form is labelled "var. obusta, Guen.," but the type of "Leucania obusta" is a very distinct species, having densely ciliated antennæ, and darker by far in colouring even than the European $H$. turca. I very much doubt whether it can be placed in the same genus.

\section{Sesamia, Guenée.}

1. Sesamia incerta.

Leucania incerta, Walker, Lep. Het., ix., p. 103, n. 58 (1856).

Nonagria intestata, Walker, l.c., p. 130, n. 23 (1856).

South Africa (Sir A. Smith). Coll. B. M.

2. Sesamia abdominalis.

Nonagria abdominalis, Walker, Lep. Het., ix., p. 131, n. 24 (1856).

Mythimna robusta, Walker, l.c., xi., p. 710 (1857).

Australia. Coll. B. M. 
3. Sesamia ciliata.

Leucania ciliata, Walker, Lep. Het., ix., p. 110, n. 77 (1856).

T'aniocampa assimilis, Walker, l. c., xv., p. 1708 (1858).

Leucania curta, Walker, l.c., Suppl., ii., p. 627 (1865).

Australia. Coll. B. M.

Platysenta, Grote.

1. Platysenta videns.

Leucania videns, Guenée, Noct., i., p. 78, n. 106 (1852). Nonagria? indigens, Walker, Lep. Het., xi., p. 713, n. 3 (1857).

Platysenta atriciliata, Grote (see Check List, p. 30).

United States. Coll. B. M.

The type from Florida is identical with the species subsequently described by Walker and Grote.

Nonagria irregularis, Walker, and Leucania proscripta, Walker, may be referred to this genus.

Nonagria, Ochs.

"Nonagria" geminipuncta, Hatchett (an example of which stood in Zeller's series of N. nexa), has simple antennæ, and is congeneric with Oria (Tapinostola) fulva.

\section{Ommatostola, Grote.}

I have been obliged to extend this genus to include the following, most of them hitherto having been placed under Nonagria :-N. canne, lutosa, sparganii, arundinis, polita of Walker (Shanghai), nexa, propria, Wlk. (New Zealand), photophila, Butl. (Hawaiian Islands), semivittata, Wlk. (New Zealand). The antennæ of these species are of the same character as those of $O$. lintneri, being thicker and more densely ciliated than in the little dull-coloured species which remain in Nonagria, viz.:-N.dissoluta, Treit., punctifinis, Walk., and neurica, Hübn. The Leucania sulcana of Fereday, which vaguely resembles $O$. semivittata, appears to me to be an Arsilonche; it is a little more developed in every way than $A$. albovenosa, the palpi, antennæ, legs, and wings being all longer; the primaries are buff instead of greyish or whity-brown, and the secondaries and abdomen are blackish instead of pure white; the pattern of the primaries, however, is almost identical. 


\section{OrThodes, Guén.}

I have already stated (Ann. and Mag. Nat. Hist., ser. 6, vol. vi., p. 96) that the type of this genus, O. $t$-nigrum, must be placed here, the whole of Guenée's other so-called Orthodes being referred to Dyschorista. Orthodes will now include O.t-nigrum from Brazil, and O. exempta (Leucauia exempta, Walk.) from Ceylon.

\section{Mycteroplus, Herr.-Sch.}

Zotheca, Grote, is synonymous with this genus.

\section{Spodoptera, Guén.}

"Spodoptera" pecten of Guenée, although it closely resembles $S$. mauritia in colouring and general pattern, is structurally quite distinct, and must either be placed in or near to the genus Agrotis.

\section{Spodoptera mauritia.}

\&, Hadena mauritia, Boisduval, Faune, Ent. de Madag., p. 92, pl. 13, fig. 9 (1833).

๙, Spodoptera nubes, Guenée, Noct., i., p. 155, n. 246 (1852).

, S. filum, Guenée, l. c., n. 248 (1852).

q, Prodenia infecta, Walker, Lep. Het., ix., p. 196, n. 12 (1856).

๙, P. insignata, Walker, l. c., p. 197, n. 14 (1856).

, Caradrina triturata, Walker, l. c., x., p. 295, n. 30 (1856).

\$, Agrotis transducta, Walker, l.c., p. 344, n. 91 (1856).

๙, Prodenia permunda, Walker, l. c., xi., p. 723 (1857).

\&, Laphygma gratiosa, Walker, l. c., Suppl., ii., p. 651 (1865).

๙, L. squalida, Walker, l. c., p. 652 (1865).

б, Prodenia venustula, Walker, l.c., p. 654 (1865).

๙, Celcena bisignata, Walker, l.c., p. 679 (1865).

+ , Agrotis aliena, Walker, l. c., p. 694 (1865).

\&, A. bisignata, Walker, l.c., p. 702 (1865).

๙, Hadena obliqua, Walker, l.c., iii., p. 736 (1865).

Africa, Asia, and Australia. Coll. B. M.

It is remarkable, considering what a number of 
species this insect was divided into, how little, comparatively, it varies; the sexes differ considerably, owing to the obliteration of the white markings in the female, but otherwise there is nothing beyond intensity of colour to account for the manifold synonymy noted above.

2 Spodoptera exempta.

ऽ , Agrotis exempta, Walker, Lep. Het., x., p. 355, n. 114 (1856).

q , Prodenia bipars, Walker, l.c., xi., p. 724 (1857).

๙, P. ingloria, Walker, l.c., xv., p. 1679 (1858).

Africa, Australia, and Hawaiian Islands. Coll. B. M.

3. Spodoptera frugiperda.

๙, 9 , Phalana frugiperda, Smith \& Abbot, Lep. Georg., ii., p. 191, pl. 96 (1797).

๙ , Prodenia signifera, Walker, Lep. Het., ix., p. 193, n. 5 (1856).

๙ , P. plagiata, Walker, l.c., p. 194, n. 6 (1856).

North and South America. Coll. B. M.

This is also $P$. autumnalis of Riley.

Prodenia, Guenée.

This genus differs from Spodoptera in the fact that the antennæ of the males are very delicately ciliated, especially towards the base, and in the much greater similarity of the sexes.

\section{Prodenia littoralis.}

Hadena littoralis, Boisduval, Faune Ent. de Madag., p. 91 , pl. 13, fig. 8 (1833).

$\checkmark$, + , Noctua retina, Freyer, Neuere Beiträge, v., p. 161, n. 865 , pl. 478 , figs. 2,3 (1845).

๙, + , Prodenia ciligera, Guenée, Noct., i., p. 164, n. 260 (1852).

, P. testaceoides, Guenée, l.c., p. 165, n. 262 (1852).

๙, P. subterminalis, Walker, l.c., p. 196, n. 13 (1856). o, P. glaucistriga, Walker, l.c., p. 197, n. 15 (1856). ๙, P. declinata, Walker, l.c., xi., p. 723 (1857).

Africa, Asia, Australia. Coll. B. M.

$P$. testaceoides is a slight variety, and $P$. declinata a starved specimen. 
2. Prodenia ornithogalli.

Prodenia ornithogalli, Guenée, Noct., i., p. 163, n. 258 (1852).

United States. Coll. B. M.

This is P. lineatella, Harvey, and $P$. commeline, Riley: I believe the following form to be only a variety, corresponding with the var. testaceoides of $P$. littoralis.

\section{2a. Prodenia eudiopta.}

Prodenia eudiopta, Guenée, Noct., i., p. 164, n. '261 (1852).

United States. Coll. B. M.

This is P. flavimedia, Harvey.

$P$. ornithogalli is the American representative of $P$. littoralis; the two forms are extremely closely allied, but that of the New World is constantly of a more uniform dark sepia-brown tint, upon which the markings stand out more sharply; the oblique dash at the end of the cell also appears to be shorter.

\section{Prodenia commelince.}

Phalana commelina, Smith \& Abbot, Lep. Ins. Georgia, ii., p. 189, pl. 95 (1797).

P.-Noctua marmorea, Sepp, Surin. Vlind. i., pl. 51.

North and South America. Col. B. M.

\section{LaPHYGMa, Guén.}

\section{Laphygma exigua.}

Noctua exigua, Hübner, Samml. Eur. Schmett., Noct., fig. 362.

ऽ, Caradrina venosa, Butler, Ent. Month. Mag., xvii., . p. 7 (1880).

Var. Laphygma cycloides, Guenée, Noct., i., p. 157, n. 250 (1852).

L.? caradrinoides, Walker, Lep. Het., ix., p. 190, n. 8 (1856).

L. flavimaculata, Harvey (see Grote, Check List, under Caradrina, p. 30, n. 651).

Europe, Asia, Africa, N. America, and Honolulu. Coll. B. $M$. 
Walker identified two normal specimens from the Cape as " $L$. cycloides," but redescribed typical $L$. cycloides (which agrees with $L$. flavimaculata in being a little larger than most European examples) as L. caradrinoides.

2. Laphygma orbicularis.

Caradrina orbicularis, Walker, Lep. Het., x., p. 294, n. $26(1856)$.

C. praterita, Walker, l.c., n. 27 (1856).

South Africa. Coll. B. M.

3. Laphygma macra.

Laphygma macra, Guenée, Noct., i. p. 157, n. 251 (1852).

L.? inepta, Walker, Lep. Het., ix., p. 190, n. 6 (1856). North and South America. Coll. B. M.

4. Laphygma cilium.

Spodoptera cilium, Guenée, Noct., i., p. 156, n. 249 (1852).

S. insulsa, Walker, Lep. Het., Suppl., 2, p. 648 (1865). Java. Coll. B. M.

"Spodoptera" erica, Butl., belongs to the same genus.

EULAPHYGMa, gen. nov.

Differs in the ciliated antennæ of the male.

Eulaphygma abyssinia.

Spodoptera abyssinia, Guenée, Noct., i., p. 154, n. 244 (1852).

S. capicola, Herrich-Schäffer, Lép. Exot., fig. 131 (1854).

Caradrina insignata, Walker, Lep. Het., x., p. 295, n. 29 (1856).

Laphygma procedens, Walker, Lep. Het., xi., p. 721 (1857).

South and West Africa. Coll. B. M.

I have no doubt that this wide-ranging species is the S. abyssinia of Guenée: it is astonishing that, when making three genera, this author failed to see how to 
separate them correctly. All the species of Laphygma are so much alike that, unless examined with a lens in detail, they might be taken for one species; yet Guenée placed $L$. cilium and $E$. abyssinia into his genus Spodoptera, the species of which are far more like those of Prodenia.

Caradrina, Ochs.

1. Caradrina extima.

Caradrina extima, Walker, Lep. Het., Suppl., 2. p. 687 (1865).

C. fidicularia, Morrison (see Grote, Check List, p. 30, n. 650).

Vancouver, California. Coll. B M.

Specimens of this species in the Grote series are labelled as "Caradrina multifera," Walk.

\section{Caradrina quadripunctata.}

Noctua quadripunctata, Fabricius, Sp. Ins., ii., p. 214, n. 25.

Caradrina pulverosa, Walker, Lep. Het., x., p. 295, n. 28 (1856).

Europe and S. Africa. Coll. B. M.

3. Caradrina selini.

Caradrina selini, Boisduval, Ind. Méth., p. 137, n. 1096. Europe. Coll. B. M.

Staudinger, in his Catalogue, p. 111, queries $C$. noctivaga as a variety of $C$. selini, and places $C$. infusca under it as a scarcely distinguishable slightly paler variety of C. noctivaga. In the Zeller collection I found the ordinary female of $C$. selini, which sex is always darker than the male, labelled as C. infusca: it is quite likely, therefore, that $C$. noctivaga and infusca are only ordinary females of $C$. selini, the sex having been not looked into.

\section{Caradrina himaleyica.}

Caradrina himaleyica, Kollar, Hügel's Kashmir, 4, p. 479 (1842).

C. arenacea, Moore, Proc. Zool. Soc., 1881, p. 349.

Dharmsala. Coll. B. M.

TRANS. ENT. SOC. LOND. 1890.-PART IV. (DEC.) 2 Y 
5. Caradrina lenta.

Caradrina lenta, Treitschke, Schmett. Eur., ii., p. 257. C. tarda, Guenée, Noct., i., p. 243, n. 389 (1852). Europe and N. America. Coll. B. M.

\section{Hydrilla, Boisd.}

1. Hydrilla lepigone.

Caradrina lepigone, Möeschler, Wien. Ent. Monatschr., 1860, p. 273.

C. miranda, Grote (see Check List, p. 30, n. 647). Europe and United States. Coll. B. M.

\section{Hурра, Dup.}

1. Hyppa xylinoides.

Hadena xylinoides, Guenée, Noct., ii., p. 106, n. 825 (1852).

Xylina contraria, Walker, Lep. Het., xi., p. 627, n. 10 (1857).

United States. Coll. B. M.

\section{Miselia, Guén.}

1. Miselia extensa.

, Belosticta extensa, Butler, Ann. \& Mag. Nat. Hist., 5th ser., vol. 4, p. 357 (1879).

๙ , Miselia cinerea, Butler, Trans. Ent. Soc. Lond., 1881, p. 184.

Japan. Coll. B. M.

\section{Meganephria, Hübn.}

The type of this genus is the so-called "Miselia" bimaculosa, which differs from $M$. oxyacanthe in the non-serrated character of its antennæ.

1. Meganephria latex.

Aplecta latex, Guenée, Noct., ii., p. 78, n. 771 (1852). Apumea demissa, Walker, Lep. Het., xi., p. 728 (1857), United States. Coll. B. M, 
Aplecta, Guén.

Mamestra stoliczke of Moore must be referred to this genus : in form it agrees best with $A$. beanii, Grote.

\section{Pachetra, Guén.}

Pachypolia Polia and Dryobota (part), Grote.

\section{Pachetra illocata.}

Hadena illocata, Walker, Lep. Het., xi, p. 758 (1857). Eurois pluviosa, Walker, l. c., Suppl., 3, p. 725 (1865). Dryobota stigmata, Grote (see Check List, p. 28, n. 535). United States. Coll. B. M.

\section{Lamprosticta, Hübn.}

Chariptera, Guén.

\section{Lamprosticta viridana.}

Phalana viridana, Walch, Naturf., xiii., p. 28, pl. iii., figs. 5, $a, b$ (1779).

Mamestra adjuncta, Walker (not Guenée), Lep. Het., xi., p. 726 (1857).

Europe. Coll. B. M.

Mr. Moore's genus Karana should be placed here.

\section{Dichonia, Hübn.}

$D$. convergens does not differ from Mamestra: $D$. aruginea therefore becomes the type of Dichonia. Walker founded a genus Horma for D. aruginea, but the specimens from which he described his genus were not what he supposed, but identical with Derthisa scoriacea, so that Horma must be suppressed.

\section{Eumichtis, Hïbn.}

1. Eumichtis plena.

ऽ, Erana plena, Walker, Lep. Het., Suppl., 3, p. 744 (1865).

q, Dianthocia viridis, Butler, Cist. Ent., ii., p. 547 (1880).

New Zealand. Coll. B. M. 
Dargida, Walk.

Eupsephopoctes, Grote.

1. Dargida graminivora.

Dargida grammivora, Walker, Lep. Het., ix., p. 202, n. 1 (1856).

Venezuela, Brazil. Coll. B. M.

This species, which is very closely allied to $D$. procinctus, Grote, is labelled, on Zeller's example, "Noctua graminivora, Moritz." Walker evidently misread the name received with the Museum specimens, which he quotes, "grammivora, Morritz [sic] MSS." The name "grammivora" is not only hybrid, but conveys no meaning; therefore I propose to restore the original reading to the species.

\section{Dargida graminicolans.}

Dianthœcia graminicolens [sic], Butler, Ann. \& Mag. Nat. Hist., ser. 5, vol. 4, p. 295, n. 50 (1878).

Madagascar. Coll. B. M.

\section{Pseudepunda, gen. nov.}

Wings broader than in Epunda, the primaries more triangular, the antennæ simple and tapering instead of denticulated and ciliated.

Type. Epunda bicolor, Moore, from India.

Synvaleria, gen. nov.

Differs from Valeria in the submoniliform, somewhat flattened, antennæ of the male, no pectinations being present.

Type. Valeria jaspidea, Vill., from Europe.

I now return to Mamestra, to which I have to add some synonyms discovered since the publication of my last paper: naturally, as I have proceeded with the Noctuce, I have seen cause to modify the arrangement of the genera, and doubtless many changes will yet have to be made before anything approaching to a natural classification can be obtained. One thing seems clearthat the numerous families made for the earlier groups are totally untenable. 


\section{Mamestra, Ochs.}

1. Mamestra binotata.

Mamestra binotata, Walker, Lep. Het., Suppl., 2, p. 663 (1865).

Hadena extersa, Walker, l.c., 3, p. 728 (1865).

H. curvata, Grote = pavia, Behr. (see Grote, Check List, p. 27, n. 450).

United States. Coll. B. M.

2. Mamestra inducta.

Mamestra inducta, Walker, Lep. Het., ix., p. 236, n. 32 (1856).

M. septentrionalis, Walker, l.c., Suppl., 2, p. 660 (1865).

Venezuela and United States. Coll. B. M.

This is labelled M. lycarum, H.-Sch., on Grote's specimens.

The Mamestra insulsa of Walker is an Agrotis allied to A. albipennis (males, having white secondaries, stood without a name in the Grote collection): M. expulsa, Walker, is another closely allied species.

Mamestra nitida, Walker, is a distorted female of Agrotis spina, Guén., without secondaries.

Mamestra punctigera ${ }^{7}$, Walk., is the male of Agrotis pastoralis \&, Grote.

Mr. Barrett pointed out to me that Walker's Mamestra configurata, from Mexico, is a slight variety of M. brassica.

\section{Hadena (typical), Guén.}

I only regard this as a group of Mamestra.

Hadena albifusa, Walk., represents $H$. trifolii in the United States, and may not be constantly different; in our examples the primaries are far less uniformly coloured, the usual markings being defined upon a paler ground colour.

The following species referred to Hadena are synonymous :-

Hadena detracta, Walk. (Mamestra claviplena, Grote), which appears to me to be a Pachnobia.

Hadena sputatrix, Grote = Apumea? insignata, Walk. 
Hadena aspera, Walker, subsequently described as $X y l i n a$ provida and $X$. canescens, Walk.

Hadena olivacea, Moore, is a synonym of $H$. megastigma, Walk., and belongs to the genus Trachea.

Hadena algeus, Grote, appears to me to be a Calathusa, and $H$. cylindrica a Bryophila.

\section{Homohadena, Grote.}

1. Homohadena infixa.

Xylophasia infixa, Walker, Lep. Het., ix., p. 178, n. 18 (1856).

Homohadena induta, Harvey (see Grote's Check List, p. 28, n. 198).

United States. Coll. B. M.

Euplexia, Steph.

1. Euplexia semifascia.

Hadena semifascia, Walk., Lep. Het., Suppl., 3, p. 737 (1865).

Euplexia cuprea, Moore, Proc. Zool. Soc., 1874, p. 578.

India. Coll. B. M.

2. Euplexia confundens.

Euplexia confundens, Walker, Lep. Het., xi., p. 544, n. 3 (1857).

E. exclusa, Walker, l. c., p. 545, n. 4 (1857).

E. indocilis (part), Walker, l.c., n. 5 (1857).

Hadena familiaris, Walker, l.c., p. 597, n. 91 (1857).

Var. H. extima, Walker, l. c., p. 599, n. 96 (1857).

H. punctisigna, Walker, l.c., p. 600, n. 97 (1857).

Tasmania, Australia. Coll. B. M.

From the fact that Walker named this species six times in one volume, it might be supposed that it was very variable. It varies only in depth of colour, the pattern being almost identical throughout. The variety extima is the most distinct, and, if proved to be locally constant, might be kept separate. 


\section{Euplexia sepultrix.}

Mamestra sepultrix, Guenée, Noct., i., p. 200, n. 317 (1852).

Hadena expulsa, Guenée, l.c., 2, p. 93, n. 800 (1852).

Euplexia emergens, Walker, Lep.Het., xi., p. 544, n. 2 (1857).

E. indocilis (part), Walker, l. c., p. 545, n. 5 (1857).

Hadena lutra, Walker, l.c., p. 598, n. 93 (1857).

Tasmania and Victoria. Coll. B. M.

This species varies a little, and much in the same manner as the preceding species, with which it might easily be confounded; the outline of the central band of the primaries, nevertheless, is very different, and the lines immediately beyond it are equidistant.

The following genus is extremely like Euplexia, some of the species differing chiefly in their pectinated antennæ, the pattern being almost exactly the same.

\section{Nyssocnemis, Led.}

1. Nyssocnemis insignis.

Euplexia insignis, Walker, Lep. Het., Suppl., 3, p. 724 (1865).

Xylina turbida, Walker, l.c., p. 754 (1865).

Var. Hadena skelloni, Butler, Cist. Ent., ii., p. 547 (1880).

New Zealand. Coll. B. M.

H. skelloni must, I think, be a well-marked variety of this species, in which the large pale patches are wanting, and the ordinary pale lines are green: when examined with a lens the markings are seen to correspond exactly.

\section{Nyssocnemis lignifusca.}

๙. Hadena lignifusca, Walker, Lep. Het., xi., p. 603, n. 101 (1857).

\& , H. debilis, Butler, Proc. Zool. Soc., 1877, p. 385, pl. xlii., fig. 6.

Xylina spurcata, Walker, Lep. Het., xi., p. 631, n. 21 (1857).

Var. X. vexata, ð, $\uparrow$, Walker, Lep. Het., Suppl. 3, p. 755 (1865). 
Var. Hadena mutans, $\widetilde{\sigma}, \uparrow$, Walker, Lep. Het., xi., p. 602 , n. 100 (1857).

Mamestra acceptrix, + , Felder, Reise der Novara, Lep. iv., pl. cix., fig. 19.

New Zealand. Coll. B. M.

This is a very common and variable species, some of the forms of which bear a considerable resemblance to Euplexia sepultrix.

The Euplexia pectinata of Warren, which closely resembles $E$. albovittata, Moore, belongs to this genus.

\section{Habryntis, Led.}

H. $v$-brunneum, Grote, appears to me to be nothing more than a variety of $H$. periculosa, in which the central belt of the primaries is blacker.

\section{Conservula, Grote.}

Conservula, Grote, Bull. Buff. Soc., ii., p. 17 (1874).

Appana, Moore, Proc. Zool. Soc., 1881, p. 355.

\section{Celmana, Steph.}

I cannot see any reason for distinguishing Hydrocia and Helotropha from this "genus." Celana is very close to Mamestra, so much so that I find that $M$. stricta (= cinnabarina) and $M$. olivacea (which looks like a black form of the same thing) undoubtedly belong to Celcena, and are closely allied to $C$. renigera; on the other hand, $M$. egens, which I considered (Trans. Ent. Soc., 1889 , p. 386, n. 7) to be identical with $M$. stricta, proves, upon a second examination by a better light, to be nearer to $M$. strigilis: Walker's type is much worn and rubbed, so that one might be excused for making it synonymous with almost any species of the same size; nevertheless, traces of the pattern can be seen with the help of a lens and bright sunlight.

Celana appears to be a fairly natural group, but the structural distinctions between it and Mamestra are not apparent on the surface.

\section{Celana renigera.}

Celana renigera, Stephens, Ill. Brit. Haust., ii., p. 16 (1829). 
synonymy of the genera of Noctuites.

C. herbimacula, Guenée, Noct., i., p. 223, n. 354 (1852).

\&, C. infecta, Walker, Lep. Het., х., p. 263 , n. 9 (1856).

United States. Coll. B. M.

\section{Celena leucostigma.}

Noctua leucostigma, Hübner, Samml. Eur. Schmett. Noct., pl. 80, fig. 375.

Var. Cerastis lavis, Butler, Trans. Ent. Soc., 1881, p. 181.

Europe, Japan, and China. Coll. B. M.

The type of $C$. laevis is an unusually large dark male, the markings upon which are ill-defined; there is, however, no question of its identity with this species. I can see no reason whatever for separating C. leucostigma, generically, from "Mamestra" splendens or "Hydrocia" nictitans.

\section{Nephelodes, Guén.}

1. Nephelodes minians.

Nephelodes minians, Guenée, Noct., i., p. 130, n. 203 (1852).

Graphiphora expansa, Walker, Lep. Het., x., p. 399, n. 26 (1856).

United States. Coll. B. M.

Grote considers $N$. violans a variety of this species, and certainly there seems nothing beyond the greyer colour of the wings, due to the absence of red in the dark bands, upon which to separate it.

\section{Var. violans.}

Nephelodes violans, Guenée, Noct., i., p. 130, n. 204 (1852).

Graphiphora subdolens, Walker, Lep. Het., x., p. 405, n. 44 (1856).

United States. Coll. B. M.

"Hadena" exornata, Mœschl., seems to me to be a very closely allied species to the preceding. 
Beluura, Walker.

Arzama, Walk.

1. Bellura gortynoides.

, Bellura gortynoides, Walker, Lep. Het., Suppl., ii., p. 465 (1865).

ð, Arzama densa, Walker, l.c., p. 645 (1865).

, A. vulnifica, Grote (see Check List, p. 29, n. 584).

United States (Georgia). Coll. B. M.

\section{Bellura obliqua.}

Edema? obliqua, Walker, Lep. Het., Suppl., 2, p. 428 (1865).

Sphida obliquata, Grote (see Check List, p. 29, n. 582).

Canada; New York. Coll. B. M.

I fail to see a sufficient reason for distinguishing this species, generically, from the preceding.

\section{Gortyna, Ochs.}

Judging from the perfect insects only, this genus seems chiefly to differ from Celana in the greater tendency of the species to become greasy, although many of the forms have a very distinct aspect, and are barely, if at all, separable from Xanthia; others, again (G. illoba, necopina, micacea, stramentosa, petasitis, and nitela), are extremely like $C$. leucostigma and allies. It is difficult to know what to do with groups of this kind, based, perhaps correctly, upon the mere clothing of the thorax, or some such apparently trivial character; they appear to be natural genera, and, therefore, I leave them as I find them.

\section{Gortyna illoba.}

Agrotis illoba, Butler, Ann. \& Mag. Nat. Hist., ser. 5, vol. i., p. 162 (1878).

Graphiphora pacifica, Butler, l.c., p. 165 (1878).

Japan. Coll. B. M.

The type of $A$. illoba is a very pale example from Haliodatè. 


\section{Gortyna micacea.}

Noctua micacea, Esper, Eur. Schmett., pl. 145, fig. 6 . Hydrocia immanis, Guenée, Noct., i., p. 128, n. 201 (1852).

Apamea obliqua, Harvey (see Grote, Check List, p. 29, n. 560).

Europe, Japan, United States. Coll. B. M.

The Japanese and American examples are, as a rule, though not invariably, a little larger and darker than those from Europe.

Gortyna nebris, Guén., is considered by Grote to be a variety of $G$. nitela: this may be the case, although the latter resembles G. petasitis, and the former is more like G. limpida; but, if Gortyna is capable of so much variation, why is $G$. harrisii described as distinct from G. rutila, into which it grades almost insensibly (one of Grote's types agrees in all respects with that of M. Guenée, having whitish secondaries; whilst another is clearly the female of his Ochria! sanzalita, a very slight variety of $G$. rutila, not worth a name): the darkest examples, having brown secondaries, may, perhaps, stand as var. harrisii. The G. rutila of Grote's collection is not Guenée's species, but the female of G. purpurifascia, Grote.

\section{Xanthia, Ochs.}

1. Xanthia indirecta.

Xınthia indirecta, Walker, Lep. Het., x., p. 468, n. 22 (1856).

Scopelosoma grafiana, Grote (see Check List, p. 32, n. 753).

United States. Coll. B. M.

Staudinger, in his Catalogue, regards the Noctua fulvago of Linneus' 'Fauna Suecica' as the Xanthia cerago of Schiffermüller; he is certainly wrong, for the Linnean description proves it, without question, to be the Euperia fulvago of Haworth. It is described as "somewhat glaucous and pale, with ferruginous bands across the primaries; secondaries paler; under surface of palpi and abdomen fulvous, of the wings pale yellow." 


\section{Ceramica, Guén.*}

1. Ceramica picta.

Mamestra picta, Harris (see Grote's Check List, p. 26, n. 343).

Ceramica exusta, Guenée, Noct., i., p. 344 , n. 574 (1852).

Mythimna contraria, Walker, Lep. Het., ix., p. 78, n. 10 (1856).

United States. Coll. B. M.

A specimen in the Zeller series is labelled, " $\mathrm{Ha}$ mulus, Z. Mamestra capucina splendens, v. Müll." Whether either of these names is published, I do not know.

$$
\text { Fagitana, Walk. }
$$

1. F'agitana littera.

Leucania littera, Guenée, Noct. i., p. 71, n. 89 (1852). Fagitana lucidata, Walker, Lep. Het., Suppl., 2, p. 645 (1865).

United States. Coll. B. M.

2. Fagitana v-album.

Ceramica v-album, Guenée, Noct., i., p. 345 , n. 577 (1852).

Apamen purpuripennis, Grote (see Check List, p. 29, n. 555).

United States. Coll. B. M.

\section{Pseinorthosia, Grote.}

\section{Pseudorthosia vetusta.}

Mythimna vetusta, Walker, Lep. Het., ix., p. 78, n. 12 (1856).

Pseudorthosia variabilis, Grote (see Check List, p. 31, n. 706).

United States. Coll. B. M.

* C. ambusta is more nearly allied to this genus than to Cirrcedia, the palpi being very short and horizontal. It should form the type of an allied genus; the subcostal furca of the secondaries is longer, and its footstalk consequently shorter; the hind tibial spurs also differ. It may be called Brachycosmia. 
The so-called "Hiptelia" miniago is the European representative of this species, and belongs to the same genus.

\section{Enargia, Hübn.}

1. Enargia decolor.

Mythimna decolor, Walker, Lep. Het., xv., p. 1658 (1858).

Var. Cosmia infumata, Grote (see Check List, p. 32, n. 735).

United States. Coll. B. M.

Brachyxanthia, Butl.

Gortyna inquasita, Grote, belongs to this genus.

\section{Cirradia, Guén.}

C. xerampelina is the type: the structure of the palpi and entire pattern and coloration of $C$. ambusta are different, and will remove it from the neighbourhood of C. xerampelina.

\section{Caltunia, Hübn.}

The type of Calymnia is $C$. trapezina: the other species may be restored to their rightful genus, Cosmia ; the latter name was erroneously applied by Lederer and Staudinger to a group of species, of which only two were included in Cosmia by Ochsenheimer (no type being indicated by him). M. Guenée distinctly indicated C. affinis as the type of Cosmia, and so it must remain.

\section{Plastranis, Boisd.}

1. Plastenis retusa.

Phalana-Noctua retusa, Linneus, Faun. Suec., p. 321. Cosmia curvata, Butler, Trans. Ent. Soc., 1886, p. 131. Europe and Japan. Coll. B. M.

The Japanese specimens are slightly larger and darker than most European examples : when I named "Cosmia curvata," we had no European representative in the general collection. This was one of the many desiderata supplied by the Zeller collection. 
Mesogona, Boisd.

1. Mesogona tadata.

f , Pseudoglaa tadata, Grote (see Check List, p. 31, n. 709).

๘ ๙, P. blanda and P. decepta, Grote (l, c., nn. 710,11).

United States. Coll. B. M.

There are only three examples-none of them perfect, and two a good deal worn-to represent the three species upon which Pseudoglea is based: as these three specimens vary less one from the other than our eight specimens of the nearly-allied $M$. acetosella, I have been reluctantly obliged to regard them as synonymous.

\section{Mesogona oxalina.}

Noctua oxalina, Hübner, Eur. Schmett. Noct., pl. 45, fig. 219.

Ipimorpha intexta, Harvey (see Grote's Check List, p. 32 , note).

Europe and N. America. Coll. B. M.

Orthosia, Ochs. Taniocampa (part), Guén.

1. Orthosia incerta.

Noctua incerta, Hufnagel, Berl. Monats., iii., p. 298, n. 424 (1767).

Taniocampa alia, Guenée, Noct., i., p. 352 , n. 587 (1852).

Europe and United States. Coll. B. M.

This is the type of Orthosia, as restricted by Curtis.

\section{GLäa, Hübn.}

\section{Glaa vaccinii.}

Phalana-Noctua vaccinii, Linnæus, Faun. Suec., p. 320. Noctua spadicea (Schiff.), Hübn., fig. 179.

Var. N. ligula, Esper, Eur. Schmett., pl. 166, fig. 3. Europe. Coll. B. M.

The describers of Exotic Lepidoptera frequently have to suffer from the bitter onslaught of men whose experience is limited to a study of the European and some- 
times of the British fauna, these men complaining that the student of tropical forms makes too many species. As a matter of fact, no men are greater hair-splitters than purely European workers. The above is only one out of many instances in which one variable species has been laboriously sorted out into three. Formerly $N$. ligula was believed to be, in all probability, a variety of N. spadicea, Schiff.; but N. vaccinii was regarded as a very distinct species. In Walker's Catalogue (part x., p. 450) $N$. ligula stands as a recognised variety. Staudinger, on the other hand (Cat., pp. 118, 119), calls spadicea an aberration of vaccinii, but raises ligula to the rank of a species. Zeller, with his seventy specimens, showing every gradation between the three forms, was sadly bothered; so that he left a typical $N$. ligula amongst his examples of $G$. vaccinii, and divided the remainder somewhere in the middle, being evidently unable to find any constant character by which to distinguish them. Is it not a sense of their own shortcomings which makes the describers of European Lepidoptera so bitter against the students of exotic species?

\section{Or rhodia, Ḧ̈̈n.}

As regards the European species, I restrict this genus to $O$. erythrocephala, vau-punctatum, and daubei, the male antennæ in all of which are ornamented with series of little tuft-like ciliations. O. signata, French, decliva, Grote, ardescens, Butl., punctosa, Walk., and viatica, Grote, must also be referred to the same genus.

An example of O. signata was labelled "Glaea anchocelioides, Guén.," in the Grote collection ; but the type of Guenée's species appears to me to be a female Noctua allied to $N$. orbis, Grote. Walker associated with it five other moths, representing three forms belonging to two different genera; of these the first three specimens were Dyschorista cynica and its variety candens, whilst the fourth and fifth were Semiophora oviduca.

\section{Orrhodia decliva.}

Orthosia decliva, Grote, on label (Epiglaa, in Check List, p. 32, n. 746). Epiglaa deleta, Grote (l.c., n. 747).

United States. Coll. B. M. 
Beyond the fact that the type of $E$. deleta is rubbed and the fringes are wanting, which last fact gives a different outline to the wings, I cannot see how it is to be separated from $O$. decliva.

\section{EPIglasa, Grote.}

I believe E. pastillicans, Morr., to be a brightly coloured form of E. tremula, Harv.; the markings are identical in the two insects.

IPIMORPHA, Hübn.

1. Ipimorpha subtusa.

Noctua subtusa, Schiff., Wien. Verz., p. 88, n. 17.

Ipimorpha pleonectusa and subvexa, Grote (see Check List, p. 32, nn. 716, 717).

Europe and United States. Coll. B. M.

The type of $I$. subvexa is larger, and has the outer line rather more incurved than in any of our other examples ; but in both of these characters we have a gradation to the smallest of European specimens. In a series of six specimens taken by Grote in Renfrew Co., Canada, there is one example smaller than some of those from Europe. The ground colour of the wings is most inconstant, one of the six specimens above referred to being darker and greyer than the greyest European specimens, the latter being of the same tint as the type of $I$ subvexa. Grote himself says of the latter, "It is possible that the southern form is only a variety of Pleonectusa"; and I am satisfied that the latter is identical with $I$. subtusa.

Radinacra, Butl.

1. Radinacra cinerascens.

Cosmia cinerascens, Motschoulsky, Etudes, ix., p. 34 (1860).

Caradrina albosignata, var. caca, Oberthür, Etudes, 5th livr., p. 74 (1880).

Japan. Coll. B. M.

ANCHOCELIS, Guén. Orthosia, Lederer \& Staudinger.

Staudinger, strangely enough, regards $A$. lunosa as the type of Anchocelis: this is manifestly impossible, as 
Guenée did not include the species in his genus when he described it. A. litura must be the type.

\section{Dyschorista, Led.}

\section{Dyschorista cynica.}

Orthodes cynica, Guenée, Noct., i., p. 375 , n. 627 (1852).

Var. O. nimia, Guenée, l.c., p. 376, n. 628 (1852).

Var. O. candens, Guenée, l. c., n. 629 (1852).

Orthosia tecta, Walker, Lep. Het., Suppl., 3, p. 714 (1865).

United States. Coll. B. M.

All the types of the above synonyms are in the Museum Collection, so that there can be no question about their identity as species.

\section{Dyschorista vecors.}

Orthodes vecors, Guenée, Noct., i., p. 376, n. 630 (1852). O. enervis, Guenée, Noct., 3, p. 400 (1852).

O. griseocincta, Harvey (see Grote, Check List, p. 31, n. 660).

United States. Col. B. M.

There is no reason for adopting Guenée's unnecessary alteration of the name of this species.

3. Dyschorista crenulata.

Dyschorista crenulata, Butler, Ann. \& Mag. Nat. Hist., ser. 6, vol. 6, p. 97 (1890).

Orthodes infirma (auct. nec Guenée).

United States. Coll. B. M.

As I have already pointed out, the Orthodes infirma of Guenée is a Brazilian species.

4. Dyschorista curvirena.

Orthodes curvirena, Guenée, Noct., i., p. 374, n. 625 (1852).

Orthosia spurcilinea, Walker, Lep. Het., xv., p. 1709 (1858).

Rio Janeiro and Venezuela. Coll. B. M.

This is such a characteristic common Brazilian species that it is impossible to mistake it for anything else.

TRANS. ENT, SOC. LOND, 1890.-PART IV, (DEC.) $2 \mathrm{z}$ 


\section{Eremobia, Steph.}

1. Eremobia brevicornis.

Xanthia brevicornis, Walker, Lep. Het., x., p. 466, n. 18 (1856).

Eremobia virescens, Butler, Ann. \& Mag. Nat. Hist., ser. 5, vol. 4, p. 243 (1879).

Congo and Madagascar. Coll. B. M.

Walker's type is so very much rubbed that, being placed far away from its natural position, it was easily overlooked; sufficient traces of the pattern still remain upon the primaries to render identification certain.

\section{Perigea, Guén.}

1. Perigea apameoides.

Perigea apameoides (part), Guenée, Noct., i., p. 229, n. 367 (1852).

P.? indecisa, Walker, Lep. Het., xi., p. 733 (1857).

P. otiosa, Walker, l.c., xv., p. 1693 (1858).

P. paupera, Walker, l. c. (1858).

Xylina detrecta, Walker, l. c., Suppl., 3, p. 750 (1856). Perigea fabrefacta, Morrison (see Grote's Check List, p. 28, n. 480 ).

North and South America. Coll. B. M.

This may prove to grade into the following species:-

\section{Perigea conducta.}

Perigea apameoides (part), Guenée, Noct., i., p. 229, n. 367 (1852).

Caradrina conducta, Walker, Lep. Het., x., p. 296, n. 32 (1856).

Perigea centralis, Walker, l.c., xi., p. 734 (1857).

Celana serva. Walker, l. c., xv., p. 1689 (1858).

Hadena pauperata, Walker, l. c., p. 1727 (1858).

Perigea inexacta, Walker, l.c., Suppl., 2, p. 682 (1865).

P. canorufa, Walker, l. c., p. 683 (1865).

P. illecta, Walker, l.c., p. 684 (1865).

Hadena leonina, Walker, l. c., 3, p. 735 (1865).

H. spargens, Walker, l.c., p. 739 (1865).

H. conducta, Walker, l.c., p. 740 (1865).

Asia, Africa, and Australasia. Coll. B. M. 
Guenée included both species under his P. apameoides; the description was evidently taken from an American example. but he noted a specimen as belonging to the East India Company, which he could not believe to be Indian. The specimen in question still retains Guenée's label : it is a $P$. conducta from Java.

\section{Perigea vecors.}

Perigea vecors, Guenée, Noct., i., p. 230, n. 371 (1852). Apamea remissa, Walker, Lep. Het., xi., p. 729 (1857). Mamestra demittens, Walker, l.c., xv., p. 1684 (1858).

North and South America. Coll. B. M.

Guenée's type is a damaged headless specimen. This species is also identical with $P$. luxa, Grote.

\section{Perigea punctifera.}

Celcena punctifera, Walker, Lep. Het., x., p. 263, n. 8 (1856).

९., C. semifusca (as ðे), Walker, l. c., xi., p. 732 (1857). B. M.

United States, St. Domingo, and Jamaica. Coll.

5. Perigea concisa.

Laphygma concisa, Walker, Lep. Het., ix., p. 191, n. 10 (1856).

Perigea imbella, Walker, l.c., xv., p. 1692 (1858).

St. Domingo. Coll. B. M.

\section{Perigea dolorosa.}

Mamestra dolorosa, Walker, Lep. Het., Suppl., 2, p. 667 (1865).

Hadena taprobance, Felder, Reise der Nov. Lep., 4, pl. ex., fig. 3.

Ceylon and Figi. Coll. B. M.

Felder's figure is much under-coloured : the primaries are very black, and the external border of the secondaries dark. The species approaches $P$. albomaculata, Moore, being intermediate between it and $P$. conducta. 
7. Perigea subornata.

Perigea subornata, Walker, Lep. Het., Suppl., 2, p. 682 (1865).

Ochria niveopicta, Butler, Proc. Zool. Soc., 1878, p. 485, n. 78.

Jamaica. Coll. B. M.

Walker's type is a broken specimen without locality.

\section{Perigea decens.}

Perigea decens, Walker, Lep. Het., x., p. 276, n. 23 (1856).

Celcena prolifera, Walker, l.c., xi., p. 732 (1857).

Perigea punctosa, Walker, l.c., p. 734 (1857).

Apamea intermittens, Walker, l. c., xv., p. 1686 (1858).

St. Domingo. Coll. B. M.

9. Perigea albigera.

Perigea albigera, Guenée, Noct., i., p. 228, n. 364 (1852).

Hadena abida, Felder, Reise der Nov. Lep., 4, pl. cix., fig. 7.

Rio Janeiro. Coll. B. M.

\section{Perigea tepens.}

Celana tepens, Walker, Lep. Het., x., p. 266, n. 17 (1856).

Perigea nigripalpis, Walker, l.c., p. 277, n. 25 (1856). Venezuela. Coll. B. M.

\section{Perigea mobilis.}

Perigea mobilis, Walker, Lep. Het., x., p. 277, n. 24 (1856).

Celana inclinata, Walker, l. c., xi., p. 732 (1857).

Perigea subaurata, Walker, l.c., Suppl., 2, p. 681 (1865).

St. Domingo, Honduras, Brazil. Coll. B. M.

Perigea albinasus, Walker, is a rubbed example of Agrotis ignobilis, Walk.; Hadena albipalpis, Walk., is 
the same species: these may therefore be added to the synonymy of $A$. ignobilis.

$P$. niveirena is not a Perigea; it would be better placed in Homohadena.

Condica, Walk.

This is only a distinctly marked group of Perigea.

1. Condica cupentia.

Noctua cupentia, Cramer, Pap. Exot., iii., pl. cclii., fig. $\mathbf{E}$ (1782).

Condica palpalis, Walker, Lep. Het., ix., p. 240, n. 1 (1856).

N. America, St. Domingo, Jamaica. Coll. B. M.

Var. C. epopea.

Noctua epopea, Cramer, Pap. Exot., iii., pl. cclxxii., figs. G, H (1782).

"Hadena" confederata, Grote, on label (see Check List, p. 28, n. 478).

United States. Coll. B. M.

\section{Var. C. infelix.}

Perigea infelix, Guenee, Noct., i., p. 229, n. 368 (1852).

N. America and Callao. Coll. B. M.

Of the above three fairly well-defined forms of a very variable species, $C$. cupentia has the primaries silvery whitish, with dark brown markings; C. epopea has the silvery colouring stained with orange ferruginous, and C. infelix has the primaries suffused with brown.

\section{Amyna, Guenée.}

1. Amyna selenampha.

Amyna selenampha, Guenée, Noct., i., p. 406 , n. 378 (1852).

Var. Alamis spoliata, Walker, Lep. Het., xiii., p. 1050 n. 11 (1857).

Hadena latipennis, Walker, l.c., Suppl., 3, p. 738 (1865).

Asia, Africa, and Australasia. Coll. B. M.

The variety twice named by Walker belongs to the 
form without a white stigma: an example of the same form from Java was labelled by Guenée with a MS. name, but he evidently came to the conclusion afterwards that it was no more than a variety, and therefore refrained from publishing it.

Amyna (part), Guenée.

Inattia, Walk.

Stridova, Walker.

Chytoryza, Grote.

1. Ilattia octo.

Perigea octo, Guenée, Noct., i., p. 233, n. 377 (1852). Poaphila stricta, Walker, Lep. Het., xiv., p. 1476, n. 21 (1857).

Ilattia cephusalis, Walker, l.c., xvi., p. 209 (1858).

Amyna undulifascia, Butler, Ann. \& Mag. Nat. Hist., ser. 4, vol. xvi., p. 403 (1875).

Ilattia apicalis, Moore, Descr. Ind. Lep., Atk., ii., p. 112 (1882).

Perigea supplex, Swinhoe, Proc. Zool. Soc., 1885, p. 452 .

\section{Var. axis.}

Amyna axis, Guenée, Noct., i., p. 407, n. 378, $b$ (1852). Celcena flavigutta, Walker, Lep. Het., xv., p. 1688 (1858).

C.? perfundens, Walker, l. c., p. 1691 (1858).

Miana inornata, Walker, l.c., Suppl., 2, p. 677 (1865). Erastria stigmatula, Snellen, Tijd. voor Ent., 15th

Jahrg., p. 55, n. 44, pl. 4, fig. 14 (1872).

Stridova albigutta, Walker, Trans. Nat. Hist. Soc. Glasgow, i., p. 35, n. 41 (1873).

Amyna stellata, Butler, Ann. \& Mag. Nat. Hist., ser. 5, vol. i., p. 162 (1878).

Chytoryza tecta, Grote (see Check List, p. 33, n. 811). Asia, Africa, America, and Australasia. Coll. B. M.

It is quite impossible, with so large a series as we possess, to separate any of the numerous synonyms associated above ; many of the descriptions were based upon single examples from widely distant localities; Guenée described his species from specimens received from Tahiti; we have examples from the Ellice, Gilbert and Marquesas Islands, the New Hebrides, Tonga, Fiji, 
and Rockhampton, answering to both his descriptions : they are, as a rule, a little smaller than the majority of Indian examples, but one specimen from the New Hebrides is as large as the largest Indian specimens representing $I$. apicalis. Perigea supplex is like examples from Marquesas. Grote's Chytoryza agrees exactly with Solomon Island specimens.

It is quite possible that $I$. cupreipennis may be only a form of $I$. octo, but the figures of this and I. cervina are so unsatisfactory that they hinder rather than assist the identification of the species; figures of closely allied species with complicated markings need to be extremely carefully executed to be of the slightest use.

Mr. Tutt has called attention to an error in my previous paper, probably:due to my being interrupted by some visitor whilst in the act of copying the synonymy from my rough notes. Agrotis saucia is not a synonym of $A$. ypsilon: therefore, the name "ypsilon" should be erased from the page and $A$. saucia substituted. As is well known, $A$. suffusa is the synonym of $A$. ypsilon: the error was purely a lapsus calami, as it did not extend to the arranged collection. In the other supposed mistakes, it is Mr. Tutt who is in error. 


$\tan .1891$ 

A few Remarks on Prof. Packard's Papers entitled "LifeHistory of Drepana arcuata" and "Hints on the Evolution of the Bristles, Spines, and Tubercles of certain Caterpillars" (Proc. Boston Soc. Nat. Hist. vol. xxiv. pp. 482-559). By A. G. Butler, F.L.S., F.Z.S., \&c.

THE above-mentioned very suggestive papers, for a copy of which I am indebted to their indefatigable author, constitute one continuous article, containing much valuable information diligently brought into a small compass. 
Whilst admitting the force of many of Prof. Packard's arguments and the truth of most of the facts upon which they are based, it appears to me that at the outset there is one great diff.culty, viz. :- If the arboreal habits of many moth-caterpillars have tended to produce hairs and spines, why is it that the greater number of butterfly-caterpillars so ornamented feed upon low plants-the Vanessce on nettles and thistles, the Argynnides on species of Viola, the Satyridæ and Hesperiidæ on grasses and low-growing plants? Why, again, are many of the most hairy moth-caterpillars, such as that of Euprepia caja, confined to low herbage?

Prof. Packard has shown that the spines and humps of many larvæ tend to assimilate them to their surroundings, thus rendering them more liable to be overlooked by insectivorous animals; the existence of this resemblance, which nobody will be inclined to deny, since all field-entomologists have repeatedly observed it, can be explained by the action of natural selection in preserving those individuals which tend thus to become less conspicuous. In the case of spined Geometrid larvæ already assimilated to twigs it seems only natural that the atrophy of the abdominal legs on the looping portion of the larva should render outgrowths from other portions of the same segments more probable, and when such outgrowths tended more perfectly to conceal the larvæ from observation there can be little doubt that they would be retained.

A few of Prof. Packard's observations are open to question, and to these I would now briefly advert.

Speaking of the larva of Dryopteris at p. 490 he says it " is as well fitted as that of Drepana by its protective mimicry to avoid the gaze of birds and insect-enemies, while its longer bizarre 'tail' renders it still more forbidding to any insect assailants." Is this an ascertained fact or only a supposition? Has any bird ever whispered to Prof. Packard that a caterpillar with a "tail" or with caudal appendages of any kind is forbidding? Is not all the talk about terrifying colours, processes, and attitudes in caterpillars pure conjecture, which experiment proves or will prove to be erroneous?

The larva of Cerura vinula has two caudal processes with exsertile tentacles, used for driving off ichneumons; but the fact that these processes are so used (as I have observed personally) is not sufficient; they are also supposed to alarm birds, although they certainly do not.

In like manner the colouring of certain caterpillars is said by many able writers to serve as a danger-signal. It is quite 
true that gaudily-coloured caterpillars are frequently avoided or very cautiously approached by insect-enemies; but it is assuming too much to declare that fear based upon reasoning is the explanation of the respect shown to such colouring; it appears to me to result rather from want of familiarity with or dislike to meddle with startlingly coloured larvæ, and can as little be attributed to reason as the dislike shown by most birds for white clothing or straw hats.

P. 497: "As hairy caterpillars are not usually devoured by birds, these hairs and spines have originated through natural selection and are danger-signals, indicating to birds that the wearers of such hirsute and bristling armature are inedible." This statement is far too broad; for, although non-insectivorous birds naturally do not touch hairy larvæ, they are known to be eaten by the Cuckoo, and I have proved repeatedly that the Missel-Thrush, Song-Thrush, Blackbird, and Chaffinch do not hesitate to kill and eat them. I have never known any bird to show apparent fear of them.

"Every one knows how efficacious any hairs or bristles are in deterring ichneumons and Tachince from ovipositing on caterpillars, and it is well known that naked or slightly piliferous larvæ are more subject to their attacks than those which are densely hairy or spinose."

I think if Prof. Packard were to collect full-grown larvæ of Euprepia caja in England he would find (as I have done repeatedly) that these densely hairy larvæ are more subject to the attacks of ichneumons than almost any caterpillar excepting that of Ganoris brassicce. I should say that at least one in five perishes from this cause, and I have even known it worse than that, for I remember on one occasion that I only reared two out of a score of these larvæ, all the rest being filled with ichneumon-maggots.

P. 509 (note): "It may be questioned whether any wingless female Lepidoptera live on herbaceous plants." Well, the larva of Orgyia antiqua is omnivorous and the larvæ of Nyssia feed on trees or low plants (according to Stainton); so that this question has already been answered.

I have thought it fair to call attention to these little blemishes in a paper the value of which I do not for a moment wish to depreciate, because in the present day some of the disciples of Darwin are, as it seems to me, far too eager to attempt to explain facts which at present we have not sufficient data upon which to argue. One thing is certain, and that is, that so long as we assume that all living creatures are endowed with the same likes and dislikes which we our- 
selves possess, and upon such an absurd assumption build up a theory, we shall hopelessly grope for real light on the problems of Nature. 


From the Annals and Magazine of Naturai. History for May 1891.

Description of a new Genus for the reception of the NorthAmerican Moths hitherto referred to Telesilla of HerrichSchäffer. By A. G. Butler, F.L.S., F.Z.S., \&c.

PLACODES CINEREOLA of Guenée, the type of the proposed new genus, was associated by its describer with the European $P$. amethystina; but as the name Placodes had been previously used in Coleoptera, Herrich-Schäffer, in the Index to his 'Schmetterlinge von Europa,' proposed to substitute for it the generic name Telesilla (subsequently duplicated in the class Aves). The date of the publication of this name was 1856 .

In 1857 Lederer, not having noticed Herrich-Schäffer's action, proposed for the same genus the new denomination of Eucarta; he, however, incorrectly stated that Diastema, Guen., was only distinguishable from it by the want of tufts on the abdomen, which was insufficient for generic separation: had this been the case the name Diastema would have necessarily superseded both Telesilla and Eucarta; but HerrichSchäffer, who examined two males, states that $D$. virgo differs so much in character from T. amethystina that it cannot stand in the same genus. In addition to the absence of the tufted dorsal crest of the abdomen (which was the only difference discovered by Lederer) he says that the margin of the fore wings is strongly sinuous and quite straight-lined, which seems a somewhat contradictory statement, but the hind wings are deeply indented at vein 5. Antennæ extremely shortly ciliated, every joint with two somewhat longer bristles.

From this I should judge that the ciliation of the antennæ was much more marked than in T. amethystina, in which, excepting when seen through a lens and in a good light, they appear to be simple. I therefore retain both genera.

As $T$. amethystina does not appear to be found in North America, although common to Europe and Japan, it is not surprising that Mr. Grote and others should have followed M. Guenée in associating the Placodes cinereola of that author with T. amethystina; but when I had the two insects before me, in the course of my rearrangement of the Noctuites, I was so struck by their different appearance and the totally dissimilar character of their markings, that I felt convinced that they could not be congeneric; I therefore asked my colleague Mr. Waterhouse to prepare the wings of duplicates of the two forms for comparison by clearing them of their scales, and the result was that I proved them to belong to entirely distinct though allied genera. 'T'he most important differences nevertheless are not in the wings but in the legs. 
OGdoconta, gen. nov.

Differs from Telesilla in its shorter primaries, with costal margin more decidedly arched towards apex, the subcostal furca, formed by the third and fourth branches, considerably longer; the rudiment of the discocellular veinlet of secondaries almost entirely obliterated; middle tibia decidedly shorter instead of longer than the femur, the interior spur longer, tarsus much more slender and longer; posterior legs longer and with longer tibial spurs; labial palpi with slightly longer terminal joint; abdomen less strongly tufted. Type $P$. cinereola.

The generic name is suggested by the markings on the primaries of $O$. cinereola.

The Japanese "Miana" segregata, Butler (Ann. \& Mag. Nat. Hist. ser. 5, vol. i. p. 85, and Ill. Typ. Lep. Het. ii. p. 25 , pl. xxix. fig. 5), is a Telesilla.

I have been unable to identify Bremer's Placodes fuscomaculata from North China; it may be not even allied to Telesilla. 


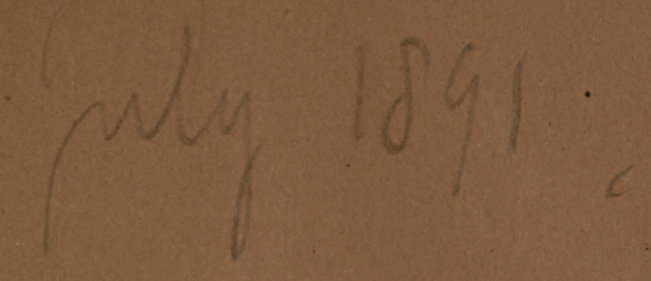



From the Annals and Magazine of Natural History for July 1891.

Revision of the Noctuid Moths in the Natural-History Museum hitherto referred to Eriopus and Callopistria. By ARTHUR G. ButLER, F.L.S., F.Z.S., \&c.

\section{[Plate IX.]}

THE genus Callopistria was founded by Hübner, in his 'Verzeichniss bekannter Schmetterlinge,' for the reception of two species, C. pteridis and C. juventina, from Europe and Surinam respectively. In all probability $C$. juventina was only known to Hübner, as it certainly was to Walker, from Cramer's figure ; and therefore $C$. pteridis (placed by both of these authors at the head of the genus) becomes the type of Callopistria.

Eriopus, Treitschke, adopted by M. Guenée for the same group and considered by Walker to be synonymous with it, had for its type $E$. pteridis, and therefore is, without question, synonymous with Callopistria.

In the 'Proceedings of the Zoological Society,' 1881, Mr. F. Moore founds two genera-Methorasa for the reception of Eriopus Latreillei, Dup., and Cotanda for Eriopus placodoides, Guen.

A careful examination of structural characters reveals the fact that the genus Callopistria as extended by Walker and 


\section{subsequent authors contains no less than nine genera, distin- guished as follows :-}

1. Primaries with rounded outer margin.

$a$. Antennæ in both sexes simple, tapering; legs strongly tufted............................ Methorasa.

$b$. Antennæ of male strongly ciliated, with a welldefined almost central twist or kink; legs almost naked

Gnamptocera.

\section{Primaries with angulated outer margin.}

$a$. Antennæ slightly pubescent in the males, rarely with a few extremely delicate cilia towards the base; very slender in the females.

$a a$. Palpi small and weak, a single dorsal tuft on the second abdominal segment; first and second pairs of legs thickly clothed with long hair scales; tibiæ of hind pair clothed with fine hair...

Haploolophus.

$a b$. Palpi large, with well-exposed terminal article; dorsal tufts, as usual, on first and second abdominal segments; legs, but especially the tibiæ of second pair, more densely hairy and tufted than in the preceding genus; a flattened fringe of dusky hair on femora of hind pair ...

Dissolophus.

ac. Palpi rather large, with exposed terminal article; dorsal tufts probably normal (imperfect in our specimens); all the legs, including the basal joint of the tarsus, densely hairy, the hind pair almost concealed by the long hairy clothing................. Hyperdasys.

b. Antennæ slender, ciliated, and with the basal third to half abruptly thickened in the males; legs moderately hairy, the spur of the middle tibiæ fringed with long hair...

Hemipachycera.

c. Antennæ of males slender, the basal two fifths usually naked, rarely pilose, always thickened, and terminating in a sloping fringed swollen bend, beyond which there is a well-defined ciliation; legs thickly clothed with long hair

Callopistria.

d. Antennæ of males much thicker, ciliated, the basal third to two fifths twice the thickness of the remainder, terminating in an enlarged acutely angular process, beyond which the ciliation is more pronounced; hairy clothing of legs very similar to that of Hemipachycera.

e. Antennæ of males with the basal two fifths thickened and strongly ciliated, especially at the thickest or distal portion, which is also serrated and emits a group of three long entangled clubbed hairs ; femora of front and hind legs and all the tibiæ fringed with long dense hair

Rhoptrotrichia. 
The admirable drawings of the structural characters occurring in this group, prepared by my friend Mr. Frohawk, have not only confirmed my decision as to the generic distinction of many of the species formerly associated under one, or latterly under four, genera, but in one or two instances they have revealed to me differences which I had overlooked when comparing one species with another. All the drawings are taken from male examples, as the most trenchant distinctive characters are found in that sex.

Should the structural differences upon which these genera are based be considered insufficient on the ground that they are secondary sexual characters, consistency will demand that at least half the genera already characterized in the order Lepidoptera shall be set aside.

The following are in the British-Museum collection:-

Methorasa, Moore.

Type Methorasa Latreillei. (Pl. IX. fig. 2.)

Eriopus Latreillei, Duponchel, Lép. Eur., Suppl. iv. p. 327, pl. cxxiii. fig. 2.

Europe and India. Coll. B. M.

\section{Methorasa argentilinea:}

Callopistria argentilinea, Walker, Lep. Het. xii. p. 863. n. 6 (1857).

United States. Type Coll. B. M.

\section{Methorasa cordata.}

Bombyx cordata, Ljung, Kongl. Vetenskaps-Akad. Handl. p. 347; pl. ii. figs. D 1, D 2 (1825).

West Indies. Hab. —? Coll. B. M.

We had a specimen of this species without locality under $M$. monetifera; it differs from the latter chiefly in its much more rufous primaries and rufous-brown secondaries; the latter are described thus:- " posticis brunneis, immaculatis; margine pallido," the fringe being pale. All the specimens of $M$. monetifera which we possess have whitish secondaries suffused with bronzy greyish towards the outer margin; so that $M$. cordata is probably the West-Indian representative of $M$. monetifera. Should the latter prove to vary considerably in a large series so as to include the West-Indian form, the name $M$. cordata will have to supersede it. 


\section{Methorasa monetifera.}

Eriopus monetifera, Guenée, Noct. ii. p. 294. n. 1098.

E. Florida, New York, \&c. Coll. B. M.

The name Herrichia, which Grote proposed for the mixed assemblage under Eriopus of the United States, cannot be retained for any of the species, as it was used by Staudinger for a genus of Lepidoptera in 1870.

Herrich-Schäffer probably compared the New-World species with the type of Callopistria, and consequently came to the conclusion that they were more delicate than the European forms. Haploolophus mollissimus is so, but the others are no more slender in structure than Methorasa Latreillei. As regards his opinion that the American species are more nearly related to Erastria (Eustrotia of Grote's ' Check-list '), I hold that the Callopistriidæx are far more nearly related to that genus than to Plusia.

\section{Gnamptocera, Butler.}

Type Gnamptocera minuta. (PI. IX. figs. 1, 1a.)

Callopistria minuta, Butler, Ill. Typ. Lep. Het. vii. p. 7, pl. cxxx. fig. 4 (1889).

Dharmsala. Type Coll. B. M.

Gnamptocera minor.

Callopistria minor, Hampson, Ill. Typ. Lep. Het. viii. p. 81, pl. clxvi. figs. 16, 17 (1891).

Nilgiris. Type Coll. B. M.

Haploolophus, Butler.

Type Haploolophus mollissimus. (PI. IX. figs. 3, 3 a.)

Eriopus mollissima, Guenée, Noct. ii. p. 294. n. 1098.

East Florida, New York, \&c. Type Coll. B. M.

Dissolophus, Butler.

Type Dissolophus chloriza.

Erıopus chloriza, Guenée, Noct. ii. p. 296. n. 1102.

Java, Type Coll. B. M. 


\section{Dissolophus aluensis, sp. n. (PI. IX. fig. 4.)}

ס. Nearest to $D$. chloriza, smaller; primaries golden argillaceous, with bands of a darker shade, the central belt more regular than usual, less constricted, with black-dotted darker edges bounded by silver lines, the discoidal markings represented by an oblique white omega; three black dots, bounded by a bisinuated white line, at base; a zigzag whitish submarginal streak from apex to near inner margin; a marginal series of black-dotted white spots; fringe tipped with silvery white and dotted with black: secondaries sericeous whity brown, greyish towards base, with a submarginal grey band ; a dark grey discocellular crescent ; two or three subapical black dots on outer margin ; fringe tipped with silvery white: body golden argillaceous; collar with one or two black dots in the centre; abdomen darker than thorax. Primaries below greyish, the borders creamy white, a blackish diffused patch divided by the subcostal vein towards end of cell; a whitish-bordered transverse irregular line crossing the wing at external third; a black oblique diffused dash, interrupted by the usual pale costal dots, at apex; black dots on the fringe as above: secondaries creamy white; costal area irrorated with black scales; discocellulars and a denticulated line beyond the middle blackish; three or four black dots on outer margin: pectus cream-coloured; venter, legs, and outside of palpi ochraceous; the usual blackish tuft at base of hind legs.

Expanse of wings 23 millim.

Alu, Solomon Islands. Type Coll. B. M.

This is smaller than either of the other species of this genus.

\section{Dissolophus repletus. (Pl. IX. fig. 5.)}

Callopistria repleta, Walker, Cat. Lep. Het. xii. p. 865. n. 13 (1857).

North India, Dharmsala; Osaka, Japan. Type Coll. B.M.

HYPERDASYs, Butler.

Type Hyperdasys exotica. (Pl. IX. fig. 6.)

Callopistria exotica, Guenée, Noct. ii. p. 294. n. 1097.

Java. Type Coll. B. M. 
Hyperdasys insularis.

Callopistria insularis, Butler, Ann. \& Mag. Nat. Hist. (5) x. p. 230 (1882).

Duke-of-York Island, Alu, Solomon group. Type Coll. B. M.

\section{Hemipachycera, Butler.}

Type Hemipachycera rivularis. (Pl. IX. fig. 7.)

Callopistria rivularis, Walker, Lep. Het. xii. p. 867. n. 15 (1857). North India, Dharmsala. Type Coll. B. M.

\section{Hemipachycera Yerburii.}

Callopistria Yerburii, Butler, Proc. Zool. Soc. 1884, p. 496. Aden and Nilgiris. Type Coll. B. M.

\section{Hemipachycera duplicans.}

Callopistria duplicans, Walker, Lep. Het. xii. p. 866 . n. 14 (1857). Moulmein and Silhet. Type Coll. B. M.

Callopistria, Hübner.

Type Callopistria purpureofasciata. (Pl. IX. figs. 9, 9 a.) Noctua purpureofasciata, Piller, Reise durch Posega, pl. vi. fig. 2 (1783), $=$ pteridis, Fabr.

Europe. Coll. B. M.

\section{Callopistria obscura.}

Callopistria obscura, Butler, Ann. \& Mag. Nat. Hist. (5) i. p. 200 (1878) ; IIl. Typ. Lep. Het. iii. p. 21, pl. xlvi. fig. 3 (1879).

Hakodate, Yokohama, Tokio, Shanghai. Type Coll. B. M.

Callopistria floridensis.

Eriopus floridensis, Guenée, Noct. ii. p. 292. n. 1094.

Florida and St. Domingo. Type Coll. B. M. 
hitherto referred to Eriopus and Callopistria.

\section{Cotanda, Moore.}

Type Cotanda placodoides.

Eriopus placodoides, Guenée, Noct. ii. p. 296. n. 110 b.

Java and Nilgiris. Type Coll. B. M.

\section{Cotanda oethiops.}

Callopistria athiops, Butler, Ann. \& Mag. Nat. Hist. (5) i. p. 200 (1878); Ill. Typ. Lep. Het. iii. p. 21, pl. xlvi. fig. 4 (1879).

Japan and Nilgiris. Type Coll. B. M.

\section{Cotanda duplicilinea.}

Plusia duplicilinea, Walker, Journ. Linn. Soc. vii. p. 70.

Sarawak. Coll. B. M.

Cotanda indica, sp. n. (Pl. IX. figs. 8, $8 a, 8 b$.)

Callopistria Yerburii, Butler, Ill. 'Тyp. Lep. Het. vii. p. 12, Index (1889).

Very like Hemipachycera Yerburii, but differing in structure, in the presence of a pencil of long bristles at base of primaries, and a fringe of long hairs on inner margin near external angle, in its deeper coloration, in the outer margin of the central belt of primaries being much less sinuous, the discoidal markings more sharply defined in white and with a diffused ochreous patch below them; the vertex of the head whitish at the margins.

Expanse of wings 29 millim.

Dharmsala, Canara, and Sarawak. Type Coll. B. M.

\section{RHOPTROTRICHIA, Butler.}

Type Rhoptrotrichia recurvata. (Pl. IX. figs. 10, 10 a.)

Callopistria recurvata, Moore, Descr. Lep. Ind. Atk, ii. p. 144 (1882);

Lep. Ceyl. iii. p. 60, pl. cli. fig. 1 (1884).

Ceylon, Java, Jubbulpore, New Hebrides. Coll. B. M.

\section{Rhoptrotrichia argyrosticta.}

Perigea? argyrosticta, Butler, Trans. Ent. Soc. 1881, p. 177.

Tokio. Type Coll. B. M. 
The type specimen is in poor condition, the fringes being lost and the antennæ broken; but the right antenna is sufficiently perfect to show that the species belongs to this genus.

Eriopus granitosa, Guen. Noct. ii. p. 295, from North America, and Eriopus ganga, p. 293, locality unknown, are not known to me.

Phaloena-Noctua juventina, Cramer, Pap. Exot. iv. pl. cccc. $\mathrm{N}$, from Surinam, is not in the Museum collection; it may be a Callopistria.

Callopistria roseitelum, Walker, Lep. Het. xii. p. 864, from the Congo, is Methorasa Latreillei.

Walker described the two following in Mr. Saunders's collection :-

Callopistria ventralis, Journ. Linn. Soc. vii. p. 64, from Borneo.

Callopistria vittata, Lep. Het., Suppl. 3, p. 811, from Brazil.

The following have also been described or figured :-

Eriopus elegantulus, Herrich-Schäffer, Corr.-Blatt zool.min. Ver. Regensb. 1868, p. 117. From Cuba.

Eriopus Doleschalli, Felder, Reise der Nov., Lep. 4, pl. cxi. fig. 14 (1874). From Amboina.

Eriopus Wallacei, Felder, l. c. fig. 26. From Amboina.

Eriopus decumana, Felder, l. c. pl. cx. fig. 25. Brazil.

Eriopus miranda, Saalmüller, Ber. senck. Gres. 1879-80,

p. 273. From Nossi-Bé.

Methorasa Thwaitesii, Moore, Lep. Ceylon, p. 61, pl. cli. fig. 2.

Eriopus reticulata, Pagenstecher, JB. nass. Ver. xxxvii. p. 226, pl. vi. fig. 7 (1884). From Amboina.

Eriopus jamaicensis, Moeschler, Abh. senck. Ges. xiv. p. 52 (sep. pag.), pl., fig. 24 (1886). Jamaica.

Eriopus venus, Staudinger, Stett. ent. Zeit. xlix. p. 253 (1888). From Amur-land.

Eriopus albolineola, Graeser, Berliner ent. Zeit. xxxii. p. 337 (1888). Amur.

Callopistria mexicana, Druce, Biol. Centr.-Amer., Het. p. 323, pl. xxx. fig. 1 (1889).

Callopistria panamensis, Druce, l. c. p. 324, pl. xxx. fig. 2 (1889).

Without examining specimens of the above I cannot venture to refer them to their proper genera; with regard to Felder's species, which are figured, they are neither related to one another nor have they any affinity to Callopistria. 
The genus Lineopalpa, Guen., from IJava, has no connexion with Callopistria, but is allied to Amphigonia.

\section{EXPLANATION OF PLATE IX.}

Figs. 1, 1 a. Legs and antennæ of Gnamptocera minuta.

Fig. 2. Legs of Methorasa Latreillei.

Figs. 3, 3 a. Legs and abdomen of Haploolophus mollissimus.

Fig. 4. Dissolophus aluensis.

Fig. 5. Legs of Dissolophus repletus.

Fig. 6. Legs of Hyperdasys exotica.

Fig. 7. Legs of Hemipachycera rivularis.

Figs. 8, 8a, 8b. Cotanda indica, antenna and legs.

Figs. 9, 9 a. Legs and antennæ of Callopistria purpureofasciata. Figs. 10, 10 a. Legs and antennæ of Rhoptrotrichia recurvata. 

Ann\&Mag.NatHist.S.6.Vol.8.PI.IX.
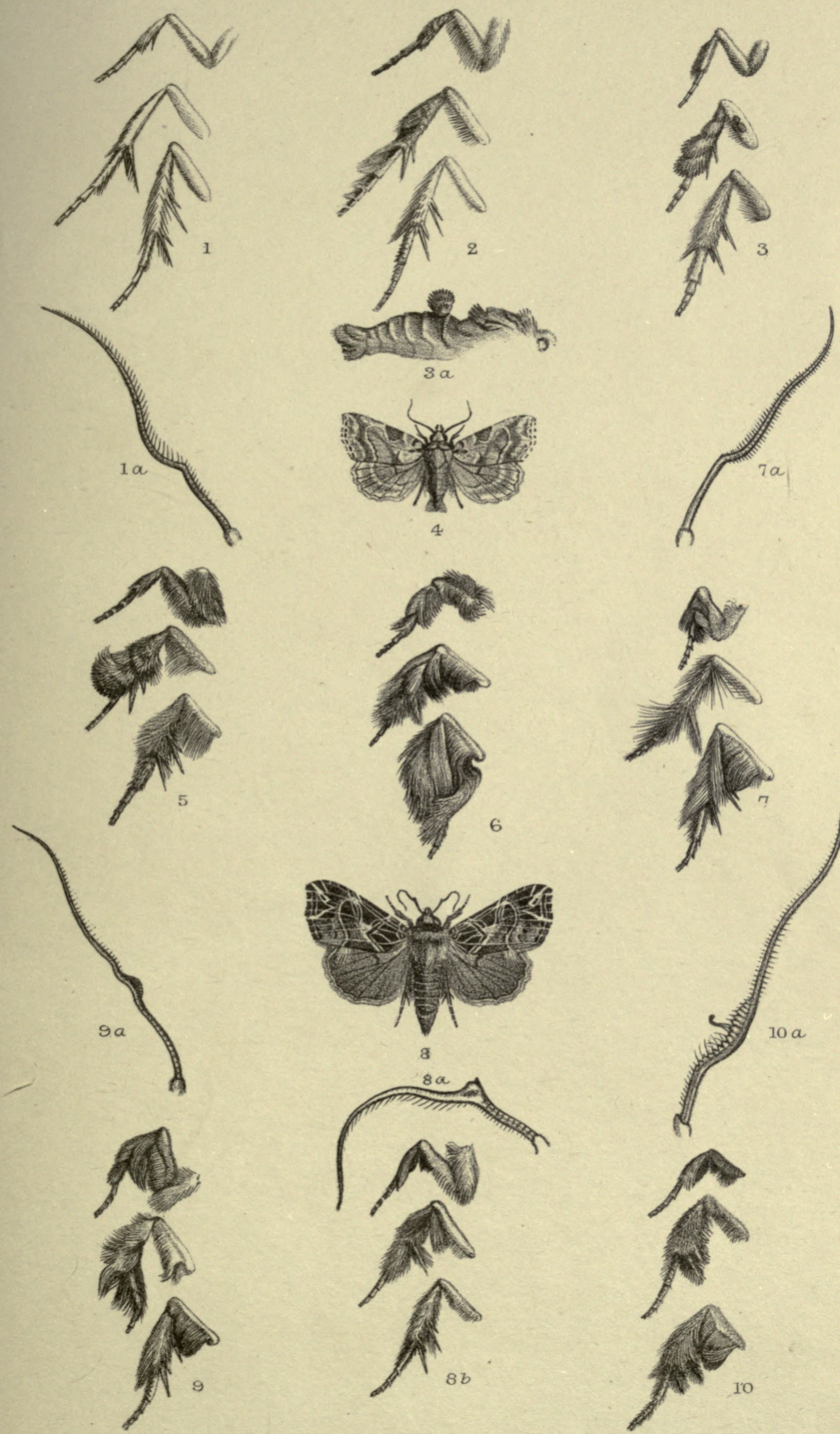

F.W.Frohawk del.etlith.

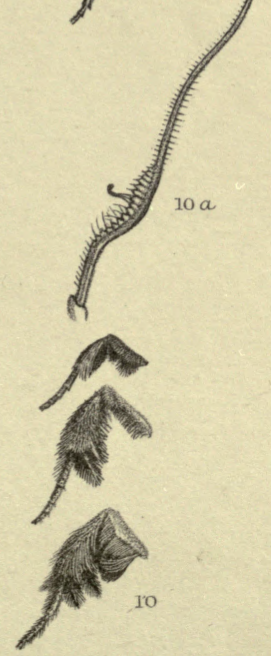

West Newmax imp. 



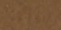



Jus 1892 

ON A

\section{COLLECTION OF LEPIDOPTERA}

FROM

SANDAKAN, N.E. BORNEO.

BY

ARTHUR G. BUTLER, F.L.S., F.Z.S., etc.

[From the Procendings of the Zoological Society of Lon Don, February 16, 1892.] 
The Lepidoptera here enumerated were obtained by Mr. W. B. Pryer and presented by him to the National Collection; many of them have suffered considerably from damp, but, fortunately, the examples of the finest of the new species are in excellent condition.

\section{RHOPALOCERA.}

This part of the collection is of little value, and the specimens are much damaged; it, however, contains examples of an interesting Elymnias. The following is a list of the species :-Calliploea mazares, Moore, Salpinx kadu, Eschscholtz, Elymnias (probably the male of $E$.penanga, Westw., black above, with the interno-basal half and a belt across the apical area of the primaries slaty lilacine), Eurytela castelnaui 오 Felder, Neptis thamala, Moore, Rahinda sandaka, n. sp.', Athyma nefte, Cram., Euthalia dunya, Hew., Lebadea padaka, Moore, Amathusia phidippus, Linn., Hypolimnas

1 Exactly like R. peraka, excepting that the submarginal band of the primaries is single instead of treble-a distinction which is believed to be constant.

$[2]$ 
wallaceana ơ, Butl., Narathura pryeri, n. sp. ${ }^{1}, N$. achelous $q$ var., Hew., Papilio prexaspes, Feld., P. evemon, Bdv., P. telephus, Feld., $P . \mid$ bathycles, Zinck., P. arycles, Boisd., P. agamemnon, Linn., Astictopterus sindu, Feld.

\section{HETEROCERA.}

Amongst these are several beautiful new insects, as well as others which are by no means abundant in collections. No Sphingida are represented, but there is a lovely new Zyganoid Arctiid.

\section{Milleria ficta.}

\section{Chalcosinde.}

Cyclosia ficta, Walker, Journ. Linn. Soc. vi. p. 97 (1862).

Milleria pontioides, Butler, Ann. \& Mag. Nat. Hist. ser. 5, rol. vii. p. 35 (1881).

Walker's description of this species is so bad that without examining the type it would be quite impossible to guess at its identity with $M$. pontioides.

\section{Callamesia striata.}

Amesia striata, Druce, Ann. \& Mag. Nat. Hist. ser. 6, vol. vii. p. 142 (1891).

This species appears to be allied to $C$. submaculans of Walker (Journ. Linn. Soc. iii. p. 185, 1860). I have to thark Mr. Druce for identifying it for me as his species.

\section{Chalcosia indistincta.}

Chalcosia indistincta, Swinhoe, in litt.

One imperfect female.

\section{ArCtinde.}

\section{Mydrothauma, n. gen.}

Nearest to Eupyra, the primaries a little narrower, the subcostal branches emitted regularly from the cell instead of branching off from the main nervure; the second and third median branches wider apart at their origins; the secondaries with strongly arched costal margins; three iustead of two median branches; palpi extremely short and porrected, instead of very long and almost erect; tibial spurs also very short; abdomen much broader, flattened and tufted at the sides. From Mydrodoxa, to which it is also allied, it differs in its considerably narrower primaries with sinuous instead of arched inner margin; in the important point of

1 Differs from $N$. amphimuta, to which it is allied and which it nearly resembles on the under surface, in its much inferior size and in the deep glistening ultramarine (rather than violet) blue colouring of the upper surface; the female, which is in the B.M. from Sarawak, has a much more restricted blue area, especially on the secondaries: expanse of wings, $\delta 43$ millim., ㅇ 40 millim. 
the absence of an accessory cell, in the non-furcate subcostal branches, in the very important point of the absence of a costal vein to the secondaries, the simple instead of forked subcostal vein, the presence of a radial vein, which in Mydrodoxa is absent, and the more slender legs with better defined tibial spurs. Altogether, in spite of a similarity in the palpi of Mydrodoxa and Mydrothauma, the latter is decidedly more nearly allied to Eupyra. Type $M$. ada.

\section{Mydrothauma Ada, n. sp. (Plate VI. fig. 1.)}

o. Nearest to M. semperi (Mydrodoxa semperi, Druce, P. Z. S. 1885 , p. 519, pl. xxxii. fig. 1), which is a true Mydrothauma, but far more beautiful; primaries ahove velvety greenish black, with three metallic violet spots forming an arched stripe across the base; a narrow band of gold with diffused greenish edges across the basal third, its inferior extremity not quite reaching the inner margin; the disk almost wholly occupied by two large unequal golden spots or patches with diffused greenish edges : secondaries intense sericeous black; the costal area grerish; a minute steel-blue spot at the end of the cell ; a trifid subcuneiform hyaline patch divided by the second and third median branches: head and collar vivid carmine; thorax velvety black, the meso- and metathorax clothed at the sides with deep smoky brown hair: abdomen blackish brown, almost black, with relrety black lateral tufts; each segment marked with lateral metallic violet-blue dashes: wings below very like the under surface of $M$. semperi, excepting that they are blacker, the discocellular veinlets are defined by metallic blue instead of green spots, and the gold and green on the external arca is much more extended; body below black, the legs and sides of venter spotted with metallic blue spots. Expanse of wings 48 millim.

A single example only of this charming novelty was captured by Mrs. Pryer, to whom (at her husband's request) I have dedicated it.

\section{Phissama vacillans.}

Amphissa vacillans, Walker, Lep. Het. iii. p. 685. n. 1 (1855).

\section{LITHOSIIDE.}

\section{Cabarda bizonoides.}

Lyclene bizonoides, Walker, Journ. Linn. Soc. vi. p. 111 (1862).

C. molliculan $a=C$. sequens is perhaps only a variety of this species.

Katha, sp. inc.

The single example is not perfect and therefore $\mathrm{I}$ hink it better not to describe it; it is like a small example of $K$. intermixta, Walk., from Southern India, but the face is greyer. 


\section{NYCTEMERIDA.}

LEPTOSOMA INTEGRUM.

Nyctemera integra, Walker, Lep. Het. Suppl. v. p. 1879 (1866). Originally described from a Philippine example.

\section{LEPTOSOMA REGULARE.}

Leptosoma regularis, Snellen, Veth's Midden-Sumatra, Lep. p. 34 (1880).

The specimen in the present collection differs from the typical form in the abbreviation of the outer marginal border of the secondaries on the upper surface.

\section{LIPARIDAE.}

\section{Adlullia guttulata.}

Euproctis guttulata, Snellen, Tijd. voor Ent. xxix. p. 36. n. 3, pl. 1. fig. 3 (1886).

One female.

Described from a Sumatran example.

Aduuldia, n. sp., Swinhoe, in litt.

A slightly damaged female.

The generic term Adlullia of Walker takes precedence of Choerotricha, Felder, as in general use. Mr. Kirby, however, holds that the type of Choerotricha is synonymous with Gogane.

\section{LIMACODIDE.}

\section{SCOPELOdes Venosa.}

Scopelodes venosa, Walker, Lep. Het. v. p. 1105.n. 3 (1855).

A male example.

The female only was previously known to us from Silhet and "E. India"; the male now sent is very like that sex of S. aurogrisea, but the abdomen is more decidedly banded with black; the abdominal half only of the secondaries is ochreous and the primaries below are more distinctly veined with whitish.

The following appears to me to be a new genus of Nycteolida; the male, from Borneo, has been for some years in the Museum collection.

\section{Nycteolide. \\ Siglophora, n. gen.}

Allied to Chandica, primaries with nearly straight costa, slightly arched external margin and more strongly arched inner margin; a deep longitudinal groove behind the costal vein on the under surface; subcostal with four ordinary branches, the two last emitted from a long footstalk; the fifth branch emitted from the end of the cell close to the upper radial, the lower radial emitted near the third median and therefore looking like a fourth median branch: secondaries rather short, deeply excised in the male on the radial interspaces, merely angulated in the female; costal vein united to the subcostal 
close to the base, separating from it at about the middle of the discoidal cell and running thence to apex; subcostal emitting two branches from the anterior angle of the cell; discocellular weak, inarched; radial emitted at the inferior angle of the cell; second and third median branches emitted from a long footstalk near to the radial: body robust, similar to that of Chandica; palpi long, thick, and compressed; antennæ, long, thick, simple; legs rather thick, the middle tibiæ armed with two unequal spurs, the inner ones very long; posterior tibiæ with four spurs. Type S. bella.

\section{Siglophora bella, n. sp. (Plate VI. fig. 2.)}

Basal three-sevenths of primaries bright lemon-yellow, ornamented by little irregular undulated lines and rings of blackish brown and bounded externally by a dark imperfect line; a costal patch beyond this area of the same colour and crossed by dark brown irregular lines; remainder of wing vinous brown in the male, rustred in the female, varied by a few inconspicuous darker spots; a deeply dentated submarginal line of yellow-indistinct in the male, but sharply defined and partly bounded internally by black spots in the female; fringe vinous, sericeous, spotted with grey : secondaries with the basal half ( $\sigma^{*}$ ) to third ( $(9)$ sericeous semitransparent white, tinted externally with yellow and bounded by a badly defined reddish band; remainder of wing vinous grey; fringe with a pale basal line: thorax bright yellow, varied with rust-red markings: abdomen bright rust-red, with a yellow spot in the centre of the basal segment, in the male specimen before me the sides and margins of the segments are pearly whitish (possibly owing to abrasion) and the anal tuft is blackish; on the under surface the defined markings have all disappeared; the yellow portions of the wings are softened down and the remaining area is grey, a reddish band separating the yellow from the grey areas: body below pearly white; palpi and fore tibiæ yellowish, banded with vinous grey. Expanse of wings, ơ 24, ㅇ 23 millim.

o, Borneo, 1879 (coll. B.M.). 오, Sandakan.

\section{NOTODONTIDA.}

Celeia, sp. inc.

A much broken example of a fine and apparently new species of this genus.

Carea, n. sp.

\section{Careide.}

Fragments of an unnamed species, shortly to be described by Col. Swinhoe, were in the collection.

\section{Drepanulide.}

\section{Drapetodes nummularia.}

Drapetodes nummularia, Snellen, Tijd. voor Ent. xxxii. n. 11, pl. 1. figs. $4,4 a$ (1889).

A single female example. 


\section{Agnidra carnea, n. sp. (Plate VI. fig. 3.)}

$\sigma^{\star}$. Sericeous pale brownish flesh-colour, sparsely irrorated with blackish atoms, which are most abundant on the outer half of the secondaries: primaries crossed by two very indistinct oblique darker lines-the first before the middle, irregular, almost $\}$-shaped, the second regular, discal, more oblique, elbowed below apex; a submarginal series of rosy spots on the veins: secondaries with two whitish stigmata on the discocellulars; under surface rosy fleshcoloured, veins ochraceous; wings sprinkled with black atoms; primaries crossed by an oblique grey discal stripe, which is vaguely continued by the black atoms across the secondaries; fore tibiæ scarlet. Expanse of wings 35 millim.

Although the apices of the primaries are broken the specimen of this very distinct species in the collection is sufficiently perfect for description.

\section{BOMBYCIDE.}

Ernolatia signata.

Ernolatia signata, Walker, Journ. Linn. Soc. vi. p. 131.

One female.

A discoloured male in the Museum from Java is named "Ocinara lida," Moore.

\section{Caradrinida.}

\section{Prodenia littoralis.}

Hadena littoralis, Boisduval, Faune Ent. de Madag. p. 91. n. 2, pl. 13. fig. 8 .

\section{Callopistrinde.}

I have waded laboriously through Walker's long paper on the Lepidoptera of Sarawak in the 'Journal of the Linnean Society' without being able to identify the three following species with certainty; the first, however, is probably his Eutelia? consentanea, and therefore I so name it, although it is not a Eutelia but belongs to a new genus allied to Hyperdasys.

\section{Pachydasys, n. gen. ,}

Primaries with straight costa, rectangular apex, and obtusely angulated outer margin; palpi broad, obliquely ascending, compressed, terminal joint short; antennæ of male subserrate, fasciculated: all the femora and tibire and the tarsi of the hind legs very broadly fringed and clothed with coarse hair-scales.

Pachydasys consentanea. (Plate VI. fig. 5.)

․ Eutelia ? consentanea, Walker, Journ. Linn. Soc. vii. p. 68. n. 313 (1864).

One male example. 


\section{Platydasys, n. gen.}

Allied to the preceding genus and to Cotanda; the wings of the same form as in Dissolophus; the antennæ most like those of Cotanda but thicker, the femora and tibir of all the legs and the tarsi of the middle and hind pairs very densely clothed with coarse hair-scales. Type $\boldsymbol{P}$. pryeri.

\section{Platydasys pryeri, n. sp. (Plate VI. fig. 6.)}

Sepia-brown with faint roseate reflections; the primaries with black and white lines and spots almost exactly as in the European Methorasa latreillei; but the reniform spot is larger and more indented in front, and the pink hastate spot immediately beyond the $s$ inuous black-edged white discal line and situated upon the upper radial vein is much less prominent, so that it is scarcely distinguishable from the remaining portion of the pale stripe bounding the external edge of the discal line. Expanse of wings 34 millim.

o, Sarawak ; + , Labuan. In coll. B.M.

A fragment of the female was obtained by Mr. Pryer in Sandakan. This species should be among the insects described by Walker; but, if so, the description is not good enough to render its identification possible.

\section{Pacilogramma, n. gen.}

Nearest to Gnamptocera, but in the pied character of its markings very dissimilar, superficially, from any of the allied genera ; antennæ normal in character, with short sparse ciliations; palpi broad, compressed, curved obliquely upwards, with short terminal joint; collar and tegulæ ample ; metathorax with prominent central crest; basal segment of abdomen probably tufted; leg's long, the front tibiæ broad, the external edge being densely fringed with coarse scales; femora of middle pair of legs flattened and grooved, the tibiæ densely clothed with hair and with two long terminal spurs; posterior legs almost naked, the tibiæ with the usual spurs. Type P. picata.

\section{Pecilogramma picatum, n. sp. (Plate VI. fig. 4.)}

Primaries above sepia-brown, spotted and streaked with black, the internal area whity brown; base white, marked with two black spots, an oblique bisinuated white stripe from the base of the costa to an oblique white band across the basal two-fifths of the wing, the latter band is traversed by a black line and is angulated at its costal extremity; an oblique white streak from the apex, interrupted by the reniform spot, which is white, oval, and encloses two unequal black spots, and the postmedian stripe, which is white, internally edged with black, zigzag and very irregular, a slightly sinuous white submarginal stripe, connected on the second median interspace by a white spot, with a marginal series of internally white-edged black dashes; fringe whitish, spotted with grey : secondaries grey, with diffused darker external border : head and collar blackish, partly 
white-edged; mesothorax buff, speckled with black; tegulæ and metathorax white, spotted and speckled with black; abdomen whitish with grey dorsal spots: primaries below smoky grey, with dull white inner margin; costa partly whitish; an indistinct transverse dark postmedian stripe and a subapical pure white spot: secondaries whitish irrorated with grey scales; a black crescent at end of cell followed by an arched discal grey stripe and a diffused grey external belt which tapers towards anal angle; body below whitish, palpi brownish, fore and middle tibiæ white barred with blackish. Expanse of wings 33 millim.

A single male example, with slightly damaged abdomen, but otherwise in good condition.

\section{HOMOPTERIDA.}

\section{HOMOPTERA CRUEGERI.}

Homoptera cruegeri, Butler, Trans. Ent. Soc. 1886, p. 411 . n. 51. Evidently a very wide-ranging species.

\section{Catephinda.}

\section{Melipotis CYLla Ria.}

Phalana (Noctua) cyllaria, Cramer, Pap. Exot. iii. pl. 251. figs. C, D (1779).

This species, which varies greatly in the coloration of the primaries (like the other species of Melipotis), is identical with $M$. cyllota and M. signivitta. Achcea purpureilinea, Walk., is probably the same species.

\section{Ophideres fullonica.}

\section{OPHIDERIDE.}

Phalana-Noctua fullonica, Linn. Syst. Nat. p. 812. n. 16.

Ophideres aurantia.

Ophideres aurantia, Moore, Proc. Zool. Soc. 1877, p. 607.

\section{Phyllodide.}

\section{Potamophora manlia.}

Phalcena-Noctua manlia, Cramer, Pap. Exot. i. p. 144, pl. 92. fig. A (1779).

The variability of this species is well known; one of Mr. Pryer's specimens is very pretty, the reniform spot and a stripe connecting it with the inner margin being bright ochreous: we have one similar example from Darjiling.

\section{Lygniodes maurus, Staud.}

An imperfect example of a fine species allied to $L$. endoleuca, but with the fringes and the abdominal area of the secondaries bright ochreous. Mr. Druce has received examples of this species from Dr. Staudinger with a name above given, but I am not certain that it has been published. 


\section{Dysgonitda.}

LAGOPTERA hoNesta.

Thyas honesta, Hübner, Samml. exot. Schmett. ii., Lep. iv., Noct. iii. figs. 1, 2.

Lagoptera magica.

Corycia magica, Hübner, Samml. exot. Schmett. Zutr. figs. 535, 536.

Ophiodes disjungens.

Othiodes (sic) disjungens, Walker, Lep. Het. xiv. p. 1360 (1857).

Pindara illibata.

Noctua illibata, Fabricius, Syst. Ent. p. 592. n. 8 (1775).

Ophisma inversa.

Ophisma inversa, Walker, Lep. Het. xiv. p. 1384. n. 34 (1857).

Achea fasciculipes.

Achrea fasciculipes, Walker, Lep. Het. xir. p. 1400.n. 20 (1857).

Serrodes campana.

Serrodes campana, Guenée, Noct. iii. p. 252. n. 1673 (1852).

An unusually lilacine example.

Dysgonia fulvotenia.

Ophiusa fulvotania, Guenée, Noct. iii. p. 272. nó 1710 (1852).

\section{AmphIGonidde.}

Amphigonia comprimens.

Amphigonia comprimens, Walker, Lep. Het. xv. p. 1540. n. 5 (1858).

\section{Thermesinde.}

\section{Platyja umminea.}

9. Phalcena-Noctua umminea, Cramer, Pap. Exot. iii. pl. 267. fig. F (1782).

Ginaa removens, Walker, Lep. Het. xv. p. 1638. n. 1 (1858).

§. Sympis subunita, Guenée, Noct. iii. p. 344. n. 1810 (1852).

Cotuza drepanoides, Walker, l. c. p. 1552. n. 1 (1858).

Both varieties of this species were obtained by Mr. Pryer.

Capnodes maculicosta.

Capnodes? maculicosta, Walker, Lep. Het. xv. p. 1608. n. 19 (18j8). 


\section{HeRMINIIDE.}

Amblygoes OILeusalis.

Herminia oileusalis, Walker, Lep. Het. xvi. p. 116. n. 38.

Madopa ? quadristrigata, Snellen, Tijd. voor Ent. 1877, p. 73, pl. 5. fig. 7 .

\section{Pyrales.}

Stericta divitalis.

Glossina divitalis, Guenée, Delt. et Pyral.p. 124. n. 20.

Arthroschista hilaralis.

Margaronia hilaralis, Walker, Lep. Het. xviii. p. 532. n. 33 (1859)

Syle PTA IOPASALIS.

Botys iopasalis, Walker, Lep. Het. xviii. p. 652. n. 182 (1859).

Mesanchyla illectalis.

Desmia ? illectalis, Walker, Lep. Het. xix. p. 931 (1859).

Talanga sexpunctalis.

Oligostigma sexpunctalis, Moore, Proc. Zool. Soc. 1877, p. 616, pl. 60 . fig. 12 .

\section{Dichocrocis pandamalis.}

Botys pandamalis, Walker, Lep. Het. xix. p. 999 (1859).

\section{SICULODID瓜.}

\section{Durdara ovifera, n. sp. (Plate VI. fig. 7.)}

Nearest to $D$. fenestrina, but differing from all the named forms of the genus in its grey coloration above and in having an oblique oval hyaline spot near the base of the first median interspace of the primaries; the outer half of the fringe of the secondaries is white; the primaries below are almost wholly glaucous grey, with white internal border, and in the secondaries the costa and veins are greyish; the palpi are even longer than in $D$. plagifera, and are whitish internally and along their inferior margins. Expanse of wings 28 millim.

Mr. Meyrick says (Trans. Ent. Soc. 1887, p. 18j) that "Microscr plagifera is a variety of Striglina myrtaa, Drury (=fenestrina, Feld., and fenestrata, Gn.), with the spot (which varies very much and is sometimes absent) unusually large. With every wish not to admit too many species, I cannot conceive that Mr. Meyrick is correct in this assertion; for, however much a spot on the wing may vary in size and shape, it appears highly improbable that the palpi would follow suit, and assuredly there is little resemblance between the palpi of $D$. fenestrina and D. plagifera (which I described as a Microsca). Our example of $D$. fenestrina is a female, and so far as can be judged from the type of D. plagifera, in which the frenulum

Proc. Zool. Soc.-1892, No. IX. 
on one side is concealed and on the other broken, the latter is of the same sex; it bas the last joint of the palpi much more slender and of nearly twice the length of that of $D$. fenestrina.

When it is proved beyond question, by carefnl breeding, that dissimilar forms are varieties of one and the same species, the sooner they are put together the better; but this guesswork, especially when concealed under the guise of an authoritative declaration, is a positive hindrance to the acquirement of accurate knowledge. In many cases where Mr. Meyrick has stated his conviction that a long series of described forms belong to one variable species, he has been subsequently obliged to alter his opinion; surely he cannot claim that his first action advanced science, since he must know of a truth that it only retarded it.

\section{Durdara robusta.}

\section{Durdara robusta, Warren, in litt.}

The type of Mr. Warren's unpublished description is from Sarawak ; it is just possible that Walker may have described it as an Anisodes or a Capnodes in his Supplement, or in one of the papers published in the Linnean Journal; but I cannot venture to attempt its identification.

\section{Pharambara vinosa, n. sp. (Plate VI. fig. 8.)}

Pale vinous-brown; wings reticulated with darker brown: primaries crossed by six imperfect darker bands, the outer edges of which, and the inner edge of the third one, are defined by blackish lines; the fourth and fifth lines are inarched towards the costa; the sixth, which is submarginal, is abbreviated and cuts off the apical half of the external horder; on the secondaries there are about three black-edged, ill-defined, abbreviated bands from the costa, the central one is acutely elbowed and bounded on each side near the centre of the wing by a hyaline, subquadrate, white spot ; on the under surface all the markings are more sharply defined, and on the primaries is a subcostal, basal, shining, pearly tuft covering the base of the frenulum. Expanse of wings 26 millim.

A single male example.

The species does not appear to be very closely allied to any named form.

\section{URAPTERYGIDE.}

Syngonorthus, n. gen.

Allied to Gonorthus : of the same form and with similar neuration; but the male antennæ much shorter and with very short fine clliations instead of being strongly pectinated.

\section{Syngonorthus subpunctatus, b. sp. (Plate VI. fig. 9.)}

Pale creamy stramineous, slightly sericeous; the wings irrorated with greyish argillaceous; the primaries crossed by two nearly parallel, straight, transverse stripes of the same colour; outer margin and fringe forming a third stripe rather more ferruginous in tint; 
costal margin narrowly ochraceous, speckled with blackish : secondaries with only a discocellular spot to represent the inner stripe of the primaries, but with a well-defined subangulated outer stripe from outer fourth of costa to inner margin, close to anal angle ; marginal stripe blacker than on the primaries: head and collar rufous-brownish : wings below without irrorations, but crossed by a straight discal series of blackish spots on the veins; primaries tinted with pink, with a transverse blackish dash on the discocellulars; pectus whitish. Expanse of wings 38 millim.

This very distinct species is unfortunately only represented by one imperfect specimen; it is, however, so unlike anything else that I have seen or of which I can find a description, that I have no hesitation in naming it.

\section{BOARMIIDE.}

Elphos hymenaria, var.

Elphos hymenaria, Guenée, Phal. i. p. 285. n. 446, pl. 16. fig. 4 (1857).

The single female obtained by Mr. Pryer has lost the white patch upon the secondaries.

\section{TERPNidia NELEARIA.}

Hypochroma nelearia, Guenée, Phal. i. p. 279. n. 444 (1857).

\section{Hypochroma NetUNaria?}

Hypochroma netunaria, Guenée, Phal. i. p. 279. n. 445 (1857).

The two examples, both females, seem to agree fairly well with the description of this species.

\section{HYPochroma vitticosta.}

Hypochroma vitticosta, Walker, Lep. Het. xxi. p. 438. n. 25 (1860).

A male example in good condition.

I have to thank Col. Swinhoe for the identification of this species; he tells me that the type from Sarawak is somewhat faded.

\section{Ascotis selenaria.}

Geometra selenaria, Schiffermüller, Wien. Verz.p. 101 ; Hübner, Geom. pl. 31. fig. 163.

A damaged female only was obtained.

\section{Zerenide.}

Panethia georgiata.

Panathia georgiata, Guenée, Phal. ii. p. 196. n. 1243.

NAXa textilis.

Naxa textilis, Walker, Lep. Het. vii. p. 1743 (1856). 


\section{Euschemida.}

\section{Euschema doubleday.}

Hazis doubledayi, Snellen, Tijd. voor Ent. xxvii. pp. lxxxii and 96-98 (1884).

\section{IDEIDA.}

\section{Chrysocraspeda vinosa.}

Chrysocraspeda vinosa, Warren, in litt.

A beautiful little bright yellow species, maculated and banded with plum-colour; it is to be hoped that a description of it will soon be published.

A much-worn example, apparently of a true Idae, new to the Museum collection, was also obtained by Mr. Pryer.

\section{Mesostrophe ovisignata.}

Anisodes ovisignata, Moore, Lep. Ceylon, iii. p. 444 (1884-7).

The specimen from Sandakan agrees perfectly well with the Ceylonese type.

\section{Caberidas.}

\section{Maresia ? undifasciata, n. sp. (Plate VI. fig. 10.)}

Basal area of wings white, speckled with black and transversely striated with pearl-grey; remainder of wings pearl-grey, striated with white and crossed to near costa by white-edged, zigzag, dark brown stripes, three on the primaries and two on the secondaries, also by a submarginal stripe, slightly wared on the primaries, but distinctly zigzag on the secondaries, the third and sixth angles filled in so as to form blackish, more or less triangular spots; a slender, slightly zigzag, black marginal line; fringe, excepting along the abdominal margin of the secondaries, very short : head and collar blackish; thorax white, speckled with black; abdomen wanting: under surface pale pearl-grey; the disk of the wings crossed by two subparallel darker grey bands, enclosing a white belt; the outer band angulated on the primaries; legs silvery whitish. Expanse of wings 33 millim.

I have been unable to find any description or figure of this lovely littie moth; judging by the descriptions alone, it would seem to be allied to Acidalia destituta and Maresia binotata, described by Walker from specimens coming from Sula and in Mr. Saunders's collection

\section{MaCaridde.}

\section{Plutodes cyclaria.}

Plutodes cyclaria, Guenée, Phal. ii. p. 118. n. 1111, pl.20. fig. 3.

\section{Trygodes divisaria.}

Macaria divisaria, Walker, Cat. Lep. Het. xxiv. p. 107 (1861). 


\section{Micronitide.}

Acropteris leptaliata.

Micronia leptaliata, Guenée, Phal. ii. p. 28. n. 935.

Pseudomicronia colata.

Pseudomicronia coelata, Moore, Descr. Lep. Atk. p. 257 (1887).

Eumeleida.

Eumelea ludovicata.

Eumelea ludoricata, Guenée, Phal. i. p. 393 . n. 629 (1857).

Geometride.

ORNithospila SUBMONSTRANS.

Geometra submonstrans, Walker, Lep. Het. xxii. p. 526. n. 36 (1861).

\section{Ornithospila cincta.}

Geometra cincta, Walker, Lep. Het. xxii. p. 527. n. 38 (1861).

This species is of the same size and general colour as the preceding, but differs in the nearly straight instead of distinctly dentate-sinuate dark green lines across the wings and in the uniformly vinous-coloured fringes.

\section{Comibana Megaspilaria.}

Phorodesma megaspilaria, Guenée, Phal. i. p. 371. n. 593.

\section{Zamarada, n. sp.}

One much shattered example of an apparently new species; its condition unfits it for description.

\section{HYBLAIDA.}

The position of this family is somewhat doubtful; the aspect of the species forcibly reminds one of the Tortrices, but the neuration does not altogether correspond with that of the Tortricida ; at the same time the Hyblaida do not appear to be true Noctuites.

Hyblea constellata.

Hyblaa constellata, Guenée, Noct. ii. p. 391. n. 1251.

EXPLANATION OF PLATE VI.

Fig. 1. Mydrothauma ada, p. 122.

2. Siglophora bella, o, p. 124.

3. Agnidra carnea, p. 125.

4. Pecilogramma picata, p. 126.

5. Pachydasys consentanea, p. 125.

6. Platydasys pryeri, p. 126.

7. Durdara ovifera, p. 129.

8. Pharambara vinosa, p. 130.

9. Syngonorthus subpunctatus, p. 130.

10. Maresia? undifascixta, p. 132. 



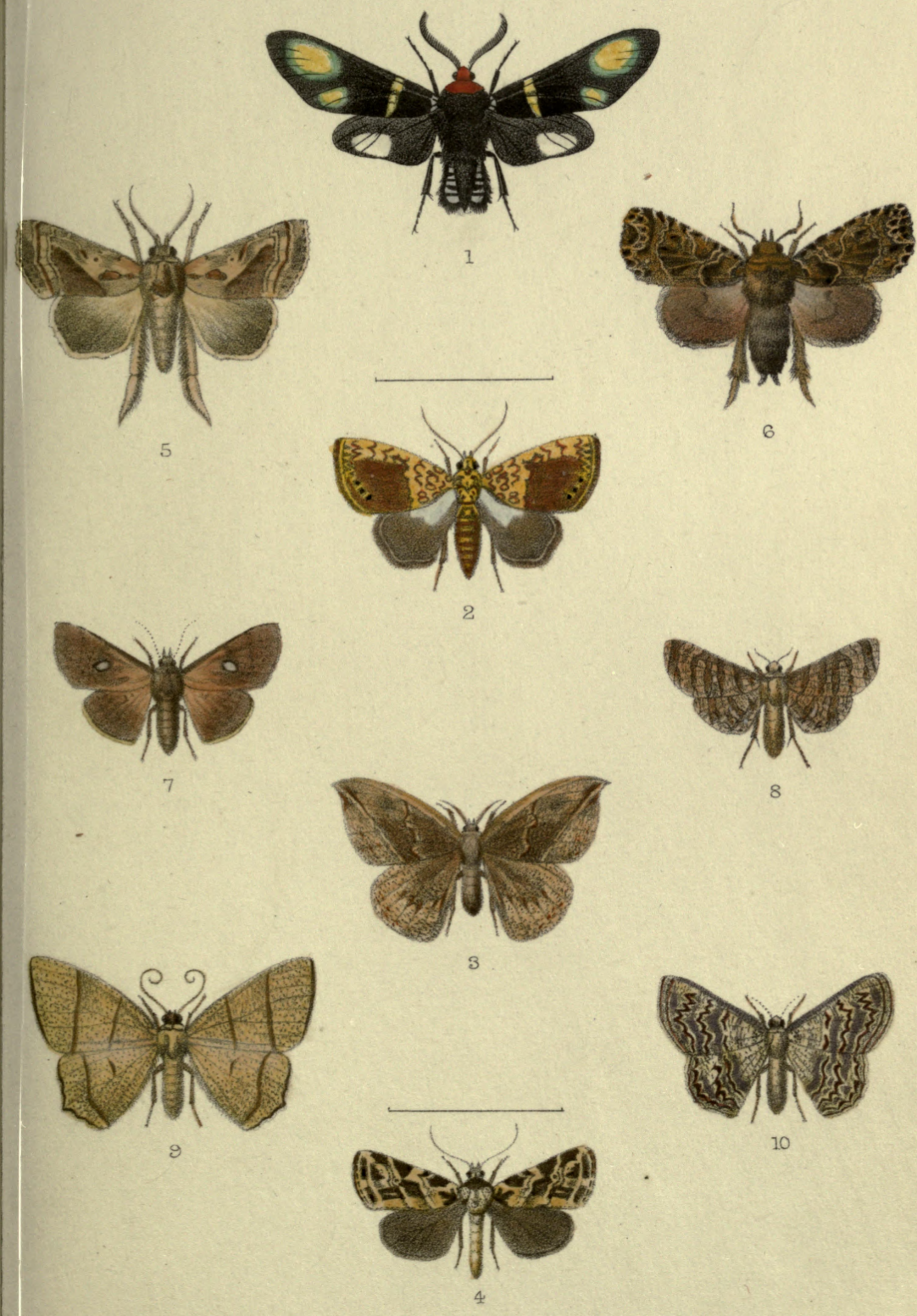





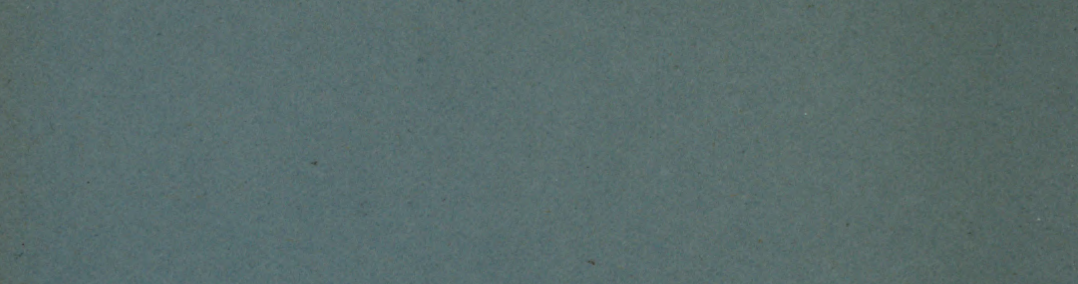

Signosis 
From the Annals and Magazine of Natural History for May 1892.

On the Genus Polychrysia of Hübner ( $a$ Group of Plusiid Moths). By Arthur G. Butler, F.L.S., F.Z.S., \&c.

IN his 'Verzeichniss bekannter Schmettlinge,' at p. 251, Hübner fonnded a genus Polychrysia on the single European species $P$. moneta. The characters given for his genus were, as usual, valueless; but the genus itself is a good one and must be adopted. It is synonymous with the genus Deva of American authors and of Walker's 'Supplement,' but has nothing to do with the typical species of that author's genus. 
Walker described his genus Deva in the twelfth rolume of his ' Catalogue of Lepidoptera Heterocera,' p. 962, and included in it two species, D. stimulans, = Plusiodonta Thome, Guen., and D. conducens, $=P$. chalcytoides, Guen. On the following page he described another new genus, Gadera, with two species, $G$. incituns and $G$. repellens, both without localities, though he concluded that G. repellens was Brazilian. As a matter of fact both are natives of Jamaica.

Now as P. compressipalpis, from the United States, is the type of Plusiodonta, and differs from all the other species associated with it in its pectinated antennæ, and as the speries of Deva and Gadera differ from one another in no character whatever, the bulk of the species of Guenée's genus Plusiodonta fall into Deva, Walker; whilst the species referred to Deva by Walker, Grote, and myself subsequently, fall into Polychrysia, Hübner.

The genus Polychrysia, in my opinion, is a true Plusiid (whereas Deva belongs to the Calpidx); it differs from typical Plusia in its enormously developed Deltoid palpi, the terminal article of which is curved, compressed, and tapering, the fringe of scalcs being elongated below the article; the outer margin of the primaries is usually, but not invariably, subangulated.

The genus Polychrysia will include $P$. splendida $=$ Deva splendida, from Japan ; P.c-aureum, = Plusia c-aureum, from Europe ; $P$. mikudina, $=$ Plusia mikadina, from Japan; $P$. purpuriger $a,=D e v a$ purpurigera, from the United States; $P$. moneta, =Plusia moneta, from Europe ; and $P$. palligera, =Deva palligera, from the United States.

Of the above species $P$. c-aureum and $P$. mikadina are nearly allied, but the former has the golden marking on the centre of the primaries of a $\circlearrowleft$-shape, whereas that on $P$. mikadina is commashaped, $\bullet$; at the same time it is quite possible that a large series will prove this to be an insufficient distinguishing character. 
awa 1042 
From the Annals and Magazine of Nateral History for July 1892.

On the Genus Hypocala, a Group of Noctuid Moths. By Arthur G. Butler, F.L.S., F.Z.S., \&c.

In the seventh volume of the 'Illustrations of Typical Lepidoptera Heterocera,' p. 76, I pointed out that the species of Hypocala were trimorphic: this fact has led to so much confusion that a revision of the species has become a necessity. When once understood the forms of this genus are easily recognizable; the primaries on the upper surface vary considerably, but always in the same way; the secondaries and the under surface are constant in pattern in all the modifications of each species.

M. Guenée, who would never identify an insect from a rough figure, and yet rarely failed to describe every differing form in his possession, however bad the specimen might be, multiplied species unnecessarily.

Whether from their rarity or the difficulty of capturing these moths, I do not know, but they seem to come to hand chiefly as individual specimens and at long intervals, so that of several of the species only one, or at most two, of the forms which represent the variations of each type have hitherto found their way to us. Mr. Hocking seems to have been more successful in collecting Fypocala than most men. In his Dharmsala series we obtained all three forms of 11. subsatura in the following proportions:-five of the typical form, four of the variety $H$. aspersa, and four of the variety $H$. limbata (the last-mentioned having, up to that time, been unrecorded).

In the following synopsis I propose to define the species hitherto described with their varieties. In order to avoid repetition in diagnosing the forms it may be premised that any good figure (such, for instance, as that given by M. Guenée, 'Noctuélites,' iii. pl. xiii. fig. 7) will represent the general characteristics in the pattern of the genus, if one allows for the more blurred uniform character of the primaries in the variety which I regard as typical, and the sharply defined but melanic character of the torm which I have characterized as var. $b$. The secondaries are always ochreous and black above, and the under surface is usually pale ochreous, more or less marked with blackish and greyish.

The under surface gives the best characters for the differentiation of the species, and therefore I shall make my primary divisions on points of difference to be seen on that surface of the wings. 
A. Wings below pale ochreous; primaries with black discal patch divided by a band of the ground-colour ; secondaries with a black spot at end of cell and an oblique bar from anal angle to second median branch.

a. Black patch on primaries broadly divided, leaving only a narrow bar of black on its inner edge; spot of secondaries small and anal bar very narrow .........

H. clarissima.

$b$. Black patch barely divided by a narrow central bar; spot of secondaries elongated, anal bar broad .........

H. violacea.

B. Wings below ochreous, greyish on costal and apical areas; primaries with a black discal patch enclosing an ovate transverse ochreous spot; secondaries with a black spot at end of cell ; an irregular, partly marginal, black band from anal angle to just above lower radial vein, its outer edge interrupted by two spots, that nearest anal angle small and angular .......

H. florens.

C. Wings below ochreous, irrorated with purplish grey on costal and apical areas; primaries with the usual black discal patch represented by two rather broad, abbreviated, parallel, oblique bars ; secondaries with a conspicuous spot at end of cell; the usual blackish band narrow, irregularly zigzag, broadly expanded at its upper extremity and extending from close to anul angle to second subcostal branch ...........

H. deflorata.

D. Primaries below almost as in B, but the black patch bounded below by the first median branch; discocellular spot quadrate; the blackish band zigzag, alternately narrow and broad, extending from near anal angle almost to the first subcostal branch.

a. Secondaries above chiefly ochreous, much more so than in any other described species ...............

H. guttiventris.

E. Wings below with cell of primaries and inner two thirds of secondaries bright ochreous, remainder of ground-colour paler; apical area greyish, the latter and costal border striated with brown atoms; primaries with two broad black bars, converging at their lower extremities.

a. Secondaries with a short, oblique, narrow, irregular black bar on the discocellulars; outer border blackish, shading into brown towards costa, becoming paler on margin towards apex and interrupted towards anal angle by an unequal, angular, ochreous, marginal patch towards

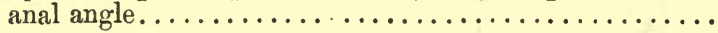

H. andremona.

b. Primaries with the black bars broader, almost touching at lower extremities; the inner bar emitting a broad grey streak below the cell almost to the base; secondaries with the blackish portion of the outer border broader, emitting a black denticle towards the lower extremity of the discocellular bar, interrupted towards the anal angle by two separate marginal ocbreous spots.

H. subsatura. 
F. Wings below with costal and apical areas smoky grey, the black or blackish bars on the primaries almost united at lower extremity, the outer one diffused; the black or blackish external belt of secondaries broad, extermally and apically diffused, excepting towards anal angle, where it is interrupted by a marginal clavate streak or spot.

$a$. Size of $H$. andremona, secondaries above with pale ochreous markings; external black border decreasing towards anal angle, deeply excavated just above the

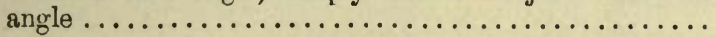

H. Moorei.

b. The largest known species; below deep ochreous, the inner black bar of primaries with an external denticle; discocellular bar of secondaries broad and externally angular; hind wings above with deep ochreous markings; external black border very broad before anal angle, moderately excavated just above the angle ...........

II. australia.

c. Similar to $b$, but with the whole under surface and the upper surface of the secondaries smoky, obscuring the markings, which are also paler and less defined in themselves

H. velans.

Of the above species, all of which are represented in the Museum collection, we possess all three varieties of two species only. For the convenience of students of the group $I$ give the following arrangement of the varieties, classified according to the colouring of the primaries, whether uniform, variegated, or bicoloured :-

Uniform.

H. subsatura.

H. deflorata.

H. guttiventris.

H. andremona.

H. australia.

H. velans.

H. florens (Mab.).

H. clarissima.

$H$. violacea.
Variegated.

H. aspersa.

H. plumicornis.

H. lativitta.

II. Pierreti.

H. Moorei.

$H$. velans.

H. florens (Mab.).
Bicoloured.

H. limbata.

H. rostrata.

H. florens (in B. M).

It seems probable that the first and second forms (which appear to be inconstant and merge into each other) are one brood, and the very distinct-looking third form another; that they represent in fact either spring and autumn or dry-and wet-season forms of the species. Whether this is so or not can only be proved by breeding, and it is worth the consideration of those who have the opportunity of obtaining the eggs or larvie. 


\section{List of Species.}

\section{Hypocala subsatura.}

๙. Hypocala subsatura, Guenée, Noct. iii. p. 75. n. 1419 (1852).

Var. a. Hypocala aspersa, Butler, P. Z. S. 1833, p. 164.

Var. b. Hypocala limbata, Butler, Ill. Typ. Lep. Het. vii. p. 76, pl. exxxi. fig. 13 (1889).

Dharmsala, Solun, and Canara. B. M.

\section{Hypocala deflorata.}

Noctua deflorata, Fabricius, Naturf. p. 190, pl. ii. figs. 6, 7.

Var. a. Hypocala plumicornis, Guenée, Noct. iii. p. 75 . n. 1420 (1852). Hypocala efflorescens, Guenée, l. c. p. 77. n. 1423 (1852).

Hypocala angulipalpis, Guenée, l. c. n. 1424 (1852).

Var. b. Noctua rostrata, Fabricius, Naturf. p. 197, pl. iv. fig. 4.

Madras, N. India, Dharmsala, Nilgiris, Kilima-njaro, Natal. B. M.

It is a common form of superstition amongst naturalists to assume that examples of the same species cannot occur both in India and Africa; M. Guenée was evidently strongly imbued with this opinion. The difference represented by the following words alone serves to separate $H$. plumicornis and efflorescens: of the first it is said, "Un seul ס", qui m'a été envoyé comme venant de la Cafrerie : mais cette provenance me laisse quelques doutes." Why? Because in other respects it closely resembled $H$. efflorescens, of which we read, "Silhet. Coll. Gn. Un đ." As for H. angulipalpis, it was based upon a single dwarfed and much rubbed example.

\section{Hypocala guttivertris.}

Hypocala guttiventris, Walker, Lep. Het. xiii. p. 1176. n. 10 (1857). Hypocala tryphanina, Felder, Reise der Nov., Lep. iv. pl. cxii. fig. 20. Var. a. Hypocala lativitta, Walker, Lep. Het. Suppl. iii. p. 929 (1865). Moreton Bay and S.E. Australia. Type B. M.

\section{Hypocala andremona.}

Phalcena-Noctua andremona, Cramer, Pap. Exot. iv. p. 132, pl. ccclviii. figs. C, D (1782).

Hypocala filicornis, Guenée, Noct. iii. p. 76 . n. 1421, pl. xiii. fig. 7 (1852).

Var. a. Hypocala Pierreti, Guenée, l. c. p. 77. n. 1425 (1852).

Honduras, Amazons, São Paulo. B. M. 


\section{Hypocala Moorei, sp. n.}

Var. a. Hypocala efforescens, var., Walker, Lep. Het. xiii. p. 1175. n. 8 (1852); Moore, Lep. Ceylon, iii. p. 126, pl. clx. figs. 5, 5 a.

Ceylon, Canara, Old Calabar. B. M.

This is quite distinct from $H$. efflorescens of Guenée.

\section{Hypocala australice, sp. $\mathrm{n}$.}

Secondaries above most like those of $H$. subsatura, but deeper and brighter in colour, with marginal ochreous spot.

Australia. B. M.

Represents $H$. velans in Australia.

Hypocala velans.

Var. a. Hypocala velans, Walker, Lep. Het. xiii. p. 1177. n. 11 (1852).

Hawaiian Islands. Type B. M.

\section{Hypocala florens.}

Hypocala forens, Mabille, Trans. Soc. Ent. Fr. 1879, p. 324.

Madagascar. B. M.

M. Mabille describes several forms of this species; our specimen belongs to the variety with pale inner border to the primaries (var. $b$ of this monograph).

\section{Hypocala clarissima, sp n.}

Differs from $H$. violacea above in the greater width of its ochreous markings.

Ceylon. B. M.

This and $H$. violacea both belong to the typical form of the genus in which the primaries are of a uniform character; both agree in having these wings of a lilacine rufous-brown colour.

\section{Hypocala violacea.}

Hypocala violacea, Butler, Trans. Ent. Soc. 1879, p. 6.

Cachar and Burmah. Type B. M.

Hypocala tenuis, Walk., from Sierra Leone, does not appear to me to belong to the genus; but the description is too poor to enable me to decide the point.

Hypocala biarcuata, Walk., from Canara, is either a species 
of Audea (Catocalidæ) or belongs to a genus allied to Audea; it has nothing to do with Hypocala.

Hypocala lativitta, Moore (said to be nearest to $H$. biarcuata), is almost certainly a species of Audea; the porrect beak-like palpi of Hypocala are not shown in the figure, which, on the other hand, gives the impression of their being formed as in Audea. 


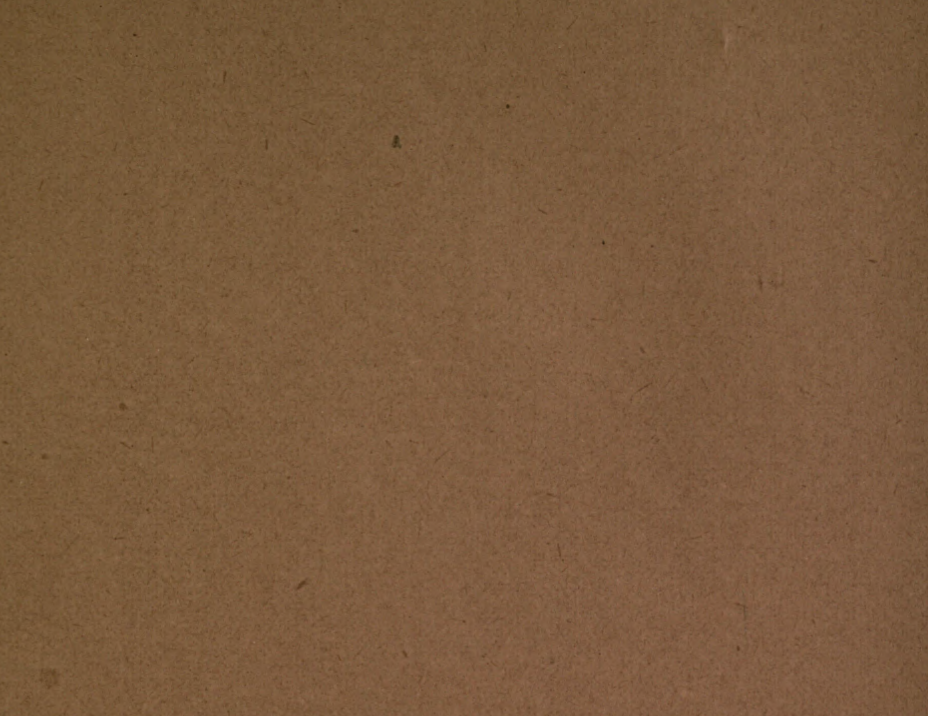

更

\section{(4)}

$x^{2} \rightarrow 0$

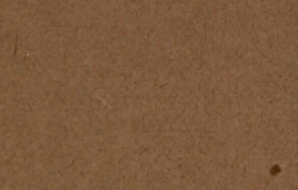

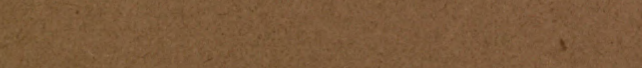

9.0.

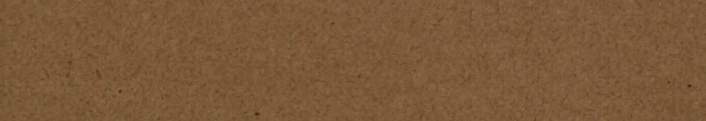

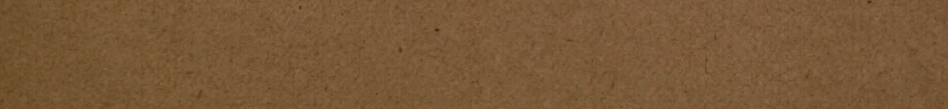




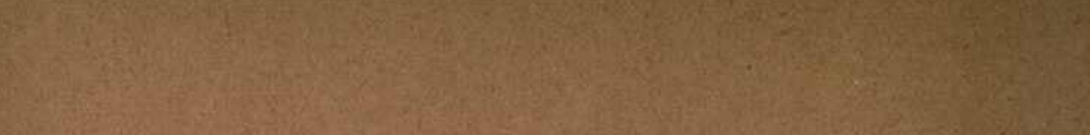
ing

S.

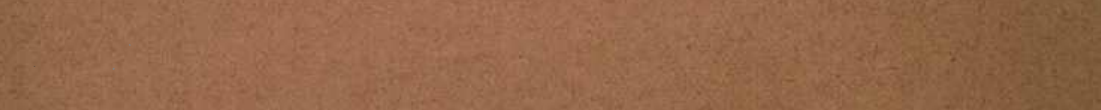
1.9. Q3.0.0. (S) - ide 30 (3) 2.5.

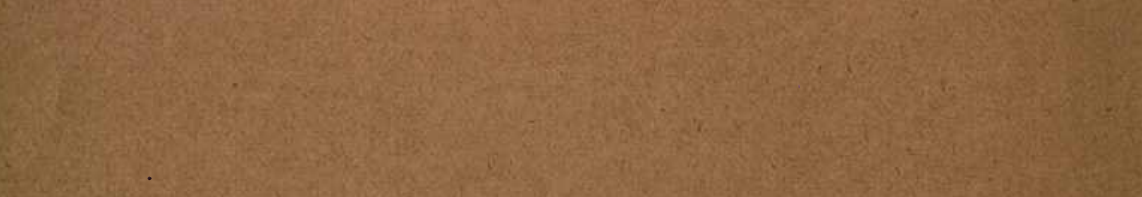

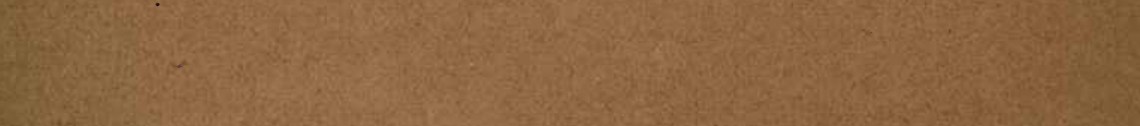
(n)

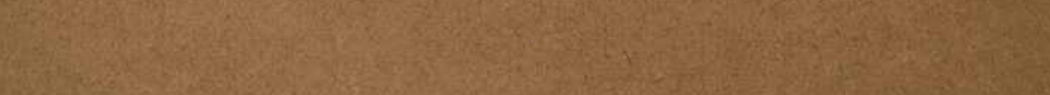
T. 
6re. 1892 


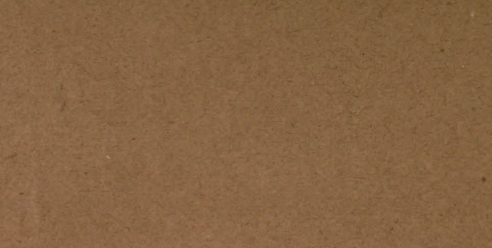

is

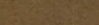

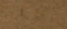

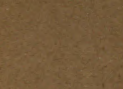

19.6.

$x^{2} z^{2}$

1

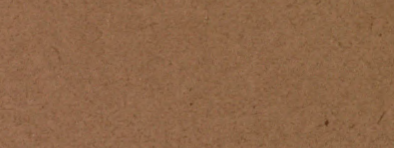

2.

- 8

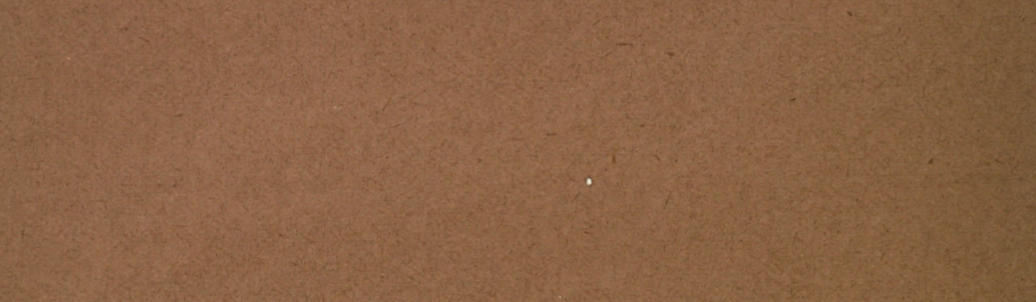

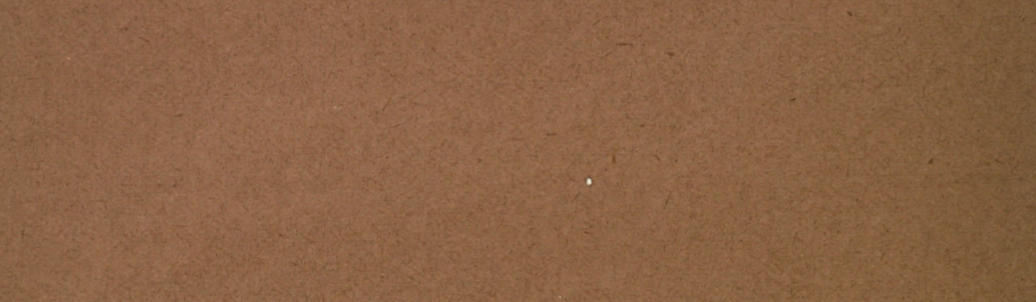

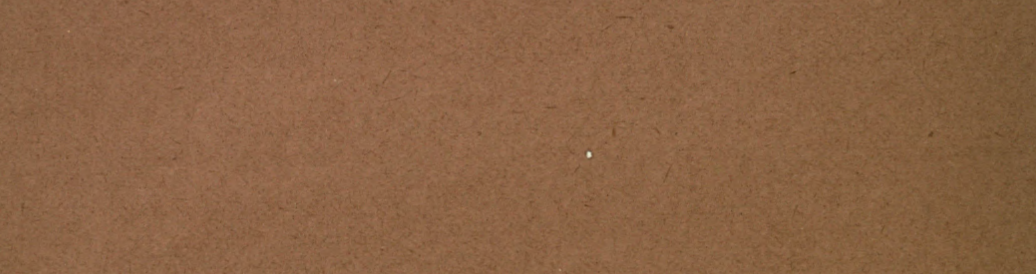

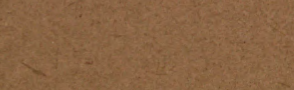
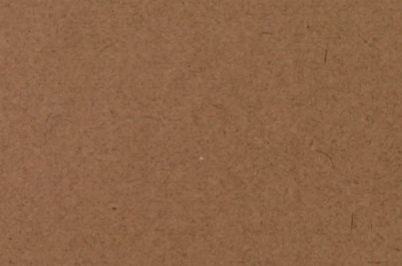

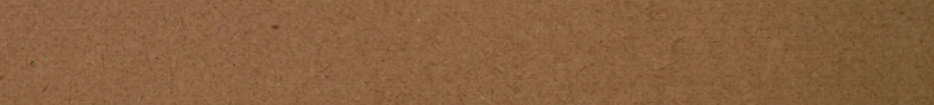
-

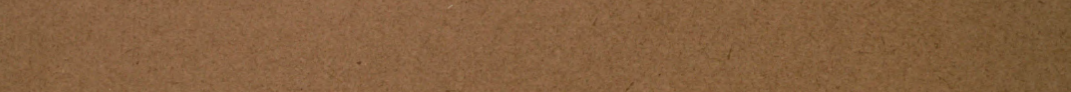

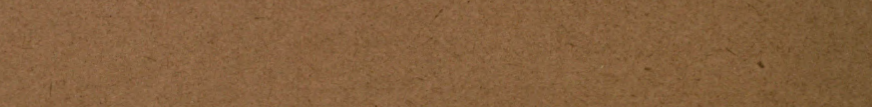

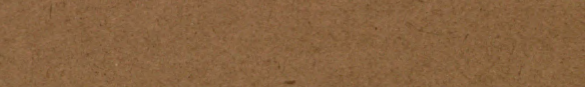

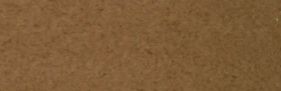

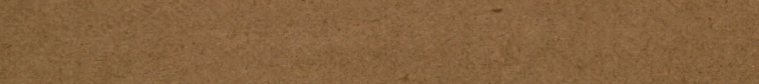


Description of a new Genus and Species of African Moths.

By A. G. Butler, F.L.S., F.Z.S. \&c.

THE following very remarkable new genus is so aberrant that, although there can be little doubt that it is distantly related to Hypena, no nearly allied form has been recorded; in the form of its wings it somewhat resembles the males of the Erosiid genus Dirades, with which, however, its structure in no respect corresponds.

I propose to name this wonderful novelty, in honour of its zealous and learned owner,

\section{HoLlandia, gen. nov.}

Primaries very broad, the costal margin arched at base, very nearly straight (if anything slightly concave) to near apex, where it is again convex, and passes almost imperceptibly into the outer margin; the latter very convex, but forming a nearly straight oblique line from third median branch to external angle, which is rather acute; inner margin slightly convex. Costal vein extending nearly to apex; subcostal five-branched, the first branch emitted before the end of the cell, the three following near together at some distance beyond it, the second and third being slightly curved upwards at costal margin, the fifth emitted, with the upper radial, from anterior angle of cell; lower radial emitted close to the second and third median branches from the posterior angle of the cell. Secondaries comparatively small, with the costal margin widely arched and forming its apex at end of third median branch; the costal and subcostal veins, which anastomose at base, consequently curving upwards to costal margin; outer margin nearly straight; abdominal margin obtusely elbowed; a large sericeous pyriform sexual patch on upper surface crossed by the radial and second and third median branches; discoidal cell very short, with the discocelular veinlet transverse and very slightly concave; the 
radial emitted from the posterior angle of the cell and close to the second and third median branches, which are emitted from a well-defined footstalk; submedian and internal veins converging at their distal extremities.

Body moderately robust; the abdomen barely extending beyond the anal angle of secondaries in length; palpi long, compressed and obliquely porrected; the second and third articles being nearly in line, the second expanding from the base forwards, its inferior fringe extending forwards below the third article, which is small and subcuneiform; antennæ delicate and finely ciliated; legs rather long, the tibiæ terminating in tufted expansions, those of the third pair of legs with a similar expansion in front of the first pair of spurs; base of ventral surface of abdomen hollowed and grooved, the surface in front of the excavation being unusually protuberant.

Type H. sigillata.

\section{Hollandia sigillata, sp. $\mathrm{n}$.}

Primaries above with the basal two fifths whitish buff, faintly suffused with lilacine greyish, sparsely dotted with blackish scales, with one or two leaden-grey markings indicating an obsolete line beyond its centre, terminated by an irregularly zigzag blackish line which interrupts a pearly blackish-margined <-shaped "reniform stigma," the angle of which is filled by a blackish-edged tawny spot; two black discoidal dots, one near the base and the other just beyond the middle of the cell; external area olive-grey, slightly greenish on costal area and otherwise slightly tinted with lilac; an imperfect oblique, zigzag, bronze-greyish stripe from costal third to just beyond the niddle of internal margin; a submarginal cupreous-brown macular stripe commencing with lunate markings which gradually change into oval spots; a black dot within the second lunule and a second near external angle, where the stripe has almost disappeared; external area and fringe slightly cupreous : secondaries whitish, tinted with pale buff, which in certain lights is shot with pink; outer two thirds of abdominal area pale greyish buff, blackspeckled, traversed by four grey stripes and bounded internally by a streak of pearl-grey spreading along the outer margin; a large pyriform, sericeous, golden tawny patch enciosing a diffused oval blackish spot on its inner edge: body pale buffish white, the head and tegulæ pale buff, speckled with blackish; collar purplish grey; palpi brownish. Wings veiow paler than above, more densely speckled with black: 
On a new Genus and Species of African Moths. 297

primaries with the internal area to second median branch shining silvery white; costa crossed by blackish oblique streaks, indicating the commencement of the lines and stripes of the upper surface; submarginal stripe present but more lunulate than above, with an arched series of four black pupils to the costal lunules: secondaries with the basi-abdominal half white, the abdominal areole pearly; a black spot at end of cell and a group of eight separated by the interno-median fold : body whitish; tibiæ brownish, with darker expansions. Expanse of wings 46 millim.

$H a b$. Gaboon.

Type in Coll. Holland. 



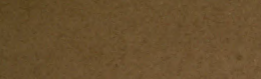

te

5.

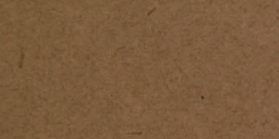

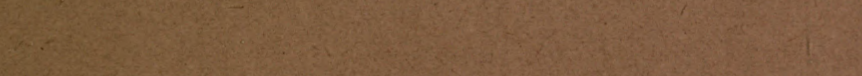



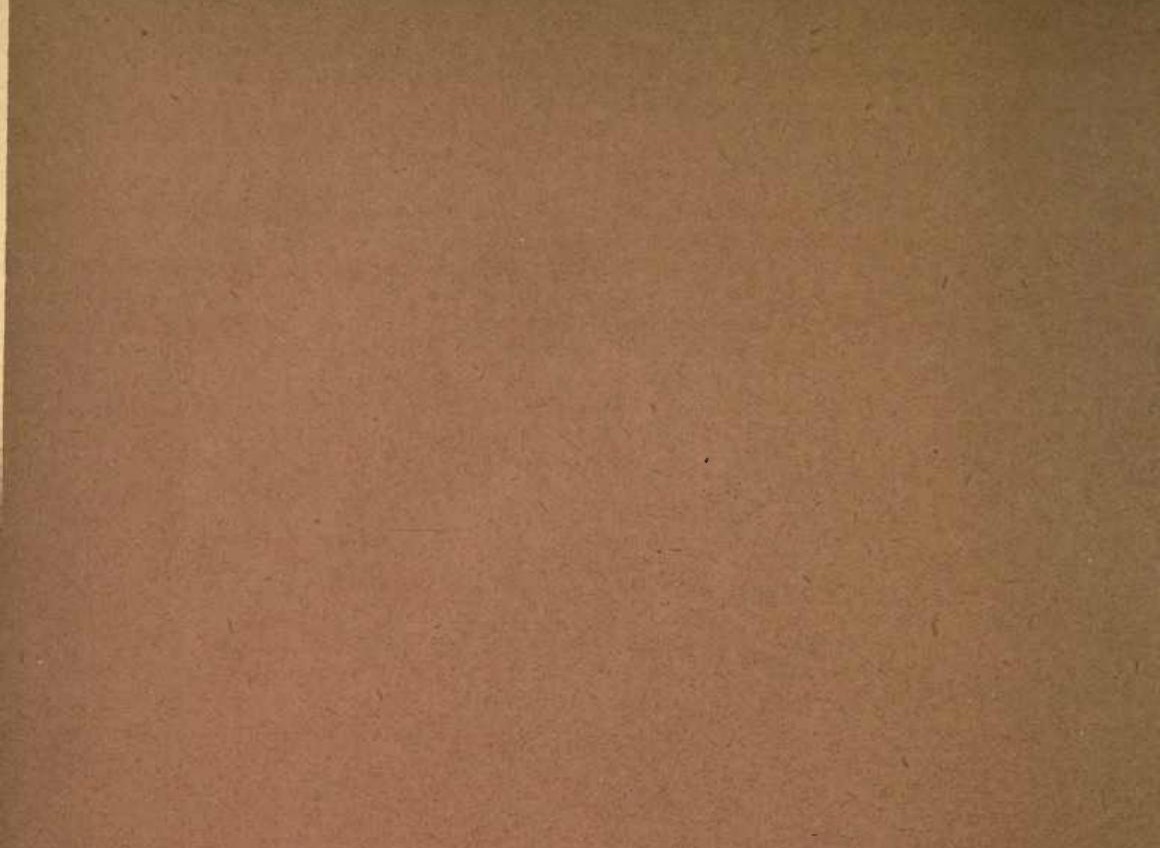

S.

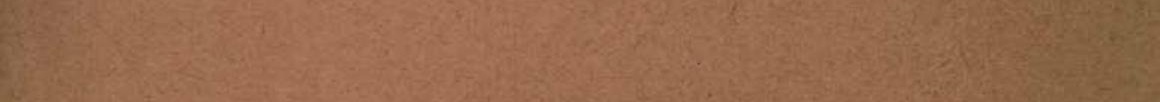
W. S.

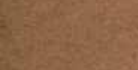

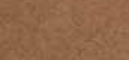

Notisy

हैं

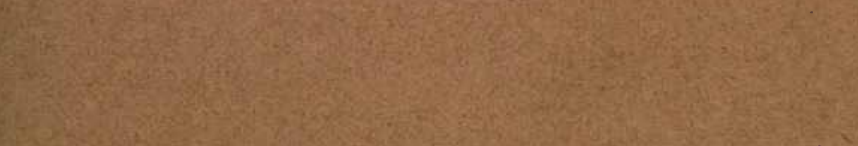

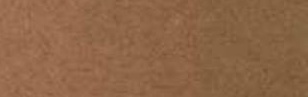

$\left(x^{2}+\frac{1}{2}+2\right.$

$20 \sin ^{2}$

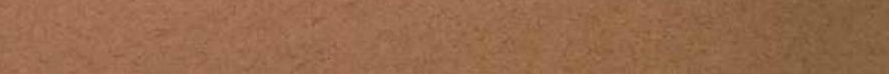

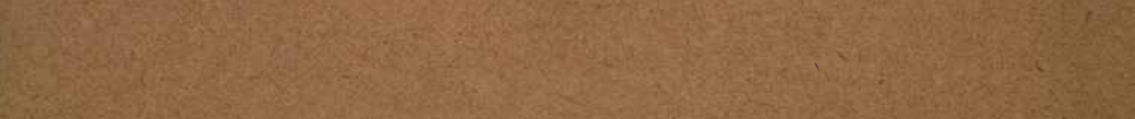

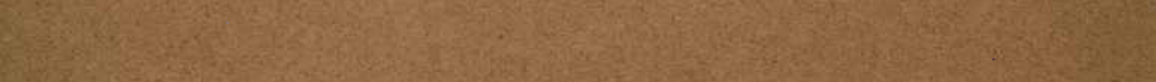
(2) 
From the Annals and Magazine of Natural History, Ser. 6, Vol. x., November 1892.

Description of a new Moth of the Genus Anaphe from Madagascar, with a Note on the Natural Position of the Genus. By Arthur G. Butler, F.L.S., F.Z.S., \&c.

THE following new species, together with its long fusiform social cocoon (not unlike that of Hypsoides bipars), was obtained by the Rev. J. Wills in the forest of East Imerina :-

\section{Anaphe aurea, sp. $\mathrm{n}$.}

Wings above uniform pale silky golden buff, the males with the basal half of the costal margin slenderly edged with black; below, the borders of the wings are more ochraceous than above. Body above testaceous, with the head and collar more or less deeply orange; antennæ and eyes black : body belog deep ochreous, the inferior edge of the palpi, a few hairs at the front of the pectus, and the tarsi of all the legs black ; the tibiæ of the anterior and middle pair black, fringed with ochreous, those of the posterior pair blackish at their distal extremity; anal tuft of female silvery above, otherwise coffee-brown.

Expanse of wings, $\delta 51, q 62$ millim.

Forest of East Imerina, Madagascar.

Four inales and two females were sent with the cocoon.

The position of the genera Anaphe and Hypsoides has long been debated by Lepidopterists. Thus Walker (Lep. Het. iv. p. 856) described Anaphe as a genus of the family Liparidæ, whilst Herrich-Schäffer in the same year referred it to the Notodontidæ under the generic name Arctiomorpha; whereas Dr. Boisduval (Voy. de Delegorgue, 1847) seems to have imagined that it was an Arctiid. In his article on Anaphe ('Trans. Linn. Soc. 1885) Lord Walsingham speaks of some of its characteristics as shared by Cnethocampa, and M. Mabille, speaking of his genus Conostegia (a synonym of Hypsoides), says that it belongs to a special division of Bombyx approaching nearly to the European Cnethocampa (Bull. Soc. Ent. France, 1890 (published 1891), p. cxlvi).

Mr. G. F. Hampson, who has recently inade a careful study of the families of the Lepidoptera, has pointed out to me that under the so-called Lasiocampidæ of authors two very distinct families are confounded, one of which (the true Lasiocampidæ) has the lower radial vein of the anterior wings emitted from the posterior angle of the cell; the other (Eupterotidæ, Hampson) emits this vein from the centre of 
the discocellular veinlet. The Eupterotidæ moreover can at once be distinguished from the Lasiocampidæ by the important character of their well-developed frenulum, this being entirely absent in the Lasiocampidæ. The larvæ of the Lasiocampidæ are densely hairy, often with long thick tufts directed forwards on either side of the head, or backwards from the anal segment, as in the Liparidæ (to which Mr. Hampson considers them allied); whereas the larvæ of the Eupterotidæ are more Arctiid in character, such hairs as there are, whether few or many, being chiefly emitted in tufts from wart-like excrescences.

There can be no doubt whatever, from the entire structure of the moths and the character of their larvæ, that Anaphe and Hypsoides must be placed in the family Eupterotidæ of Hampson. 
Jay 1893 

From the Annals and Magazine of Natural History,

Ser. 6, Vol. xi., May 1893.

Notes on the Genus Acronycta of Authors and its Position in the Classification of Heterocerous Lepidoptera. By A. G. Butler, F.L.S., F.Z.S., \&c.

IN the 'Transactions of the Entomological Society' for 1879 I proposed (pp. 313-317) to break up the old genus Acronycta and distribute it, chiefly on account of its very distinctive larval characters, amongst the various families of Bombyces \&c. to which the peculiarities of the larvæ seemed to show affinity. It must, however, be borne in mind that my conclusions were based chiefly upon the larvæ of the British species and the published illustrations of Abbot; nevertheless I examined the neuration of the species in each group, comparing it with that of each of the families to which the larval types seened to point.

Unfortunately, at the time when I wrote my paper the importance of the position of certain veins in the wings of moths, as having more than generic value, was not so fully appreciated as at the present time; therefore, although I correctly represented the venation of the Notodontidæ, I failed to see that the position of the median branches and lower radial of the primaries in that family precluded the possibility of any Acronycta being regarded as even remotely allied to it. On the other hand, it is now known that the Liparidæ and Arctiidæ are much more nearly related to the Noctuæ than was formerly supposed; so that the similarity in neuration is by no means surprising, nor is there any reason why larval characters found in the former should not also occur in a genus of Noctuæ.

A recent study of the transformations of Acronycta in Abbot's unpublished volumes has now clearly shown that the differences in the clothing and outline of the larvæ characteristic of the Bombycid families already referred to occur in various species of the same group in Acronycta, and so are valueless as indicative of their affinities. I am therefore obliged to renounce my former opinion and admit that Acronycta is in truth a genus of Noctuæ, probably nearest allied to Polia.

The sections into which Acronycta has been divided may still be used (as having the value of numerals only) to indicate the near affinities of the species; and, as the Museum series is represented by nearly eighty species, I propose to indicate them below. I must, however, first point out that Acronycta simplex of Walker is Xylomyges crucialis of Harvey, and 
that Hadena externa of Walker (which I formerly placed in Tricena) is probably a very worn and stained specimen of Bryophila muralis, Forst.; its neuration certainly corresponds closely with that of Bryophila, and such markings as can be traced are also found in $B$. muralis. I have failed to recognize Acronycta declarata, Walk., A. telum, interrupta, and pachycephala, Guen.; though the description of A.interrupta is rather suggestive of $A$. vinnula, Grote, the absence of the illustration upon which M. Guenée based it from the Museum collection of drawings prevents its being satisfactorily identified. Possibly $A$. telum and pachycephala may be known to our American friends; but we possess no specimens so labelled.

Grote's group Merolonche seems to me to be far more distinct than the other sections of Acronycta and may perhaps prove to have generic value, the thicker antennæ of the males and the well-developed lateral anal tufts, combined with the regular fasciated character of the markings, should, I think, have some significance. A. lithospila, Grote, appears to me to be closely allied to the European Scotochrosta pulla, and cannot, I think, be an Acronycta; nor can I believe that A. lanceolaria and insolita, Grote, should be widely separated from the latter or firom Cucullia. I therefore admit Eulonche, for these two species, as a genus.

One or two of the American species which have been wrongly identified I shall be obliged to rename.

Acronycta (Acronicta, sic, Ochs.).

Typical Section.

1. A. leporina, Linn., and var. bradyporina, Treit. Europe.

*2. A. felina, Grote. United States.

3. A. lepusculina, Guen., and var. populi, Riley. Hudson's Bay \&c.

*4. A. insita, Walk. United States and Canada.

*5. A. innotata, Guen. New York, Hudson's Bay, Canada, \&c.

Of the above we possess the types of 2,4 , and 5 . To save trouble I shall indicate all species of which we possess the type specimens by an asterisk. 
Mr. A. G. Butler on the Genus Acronycta.

Section Megacronycta, Grote.

1. A. americana, Harris.

A. acericola?, Guen. New York and Foochow.

*2. A. dactylina, Grote. United States.

3. A. hastulifera, Sm. Abb.

* ठ. A. contacta, Walk. New York and Hudson's Bay.

In the Grote collection an example of $A$. americana was labelled $A$. hastulifera; but the figure corresponds far more closely with a female recognized as the latter and labelled by M. Guenée. We have a fourth species of this group from Ichang $\dagger$.

Section ARcromyscis, Hübn.

1. A. aceris, Linn. Switzerland, Christiania, Livonia, \&c.

2. A. abscondita, Treit. North Germany, Hungary.

3. A. euphrasia, Esper. Sicily, Russia.

4. A. euphorbice, Gmel. Switzerland, Germany, \&c.

*5. A. sperata, Grote. New York.

*6. A. tota, Grote. Texas.

No. 6 is so much nearer to the dark variety of $A$. aceris than to any species of the section Trioena, that I have without hesitation placed it here.

Section Apatela, Grote (Apatelat, part., Hübn.).

1. A. hercules, Feld. Yokohama and Tokio.

2. A. rubricoma, Guen. Philadelphia and Texas.

3. A. luteicoma, Grote. Kansas.

*4. A. pallidicoma, Grote. Illinois.

*5. A. impressa, Walk.

A. fasciata, Walk., and Verrillii, Grote.

A. brumosa, Grote (not Guen.). Hudson's Bay \&c.

† I hesitate to describe the latter, Messrs. Leech and Oberthür having done so much work in the Chinese fauna of late years as to render such a course risky. 
*6. A. distans, Grote. United States.

7. A. megacephala, Schiff. Zurich, Frankfort, \&c.

8. A. noctivaga, Grote. New York and Canada.

9. A. superans, Guen. New York and Canada. *10. ․ A. brumosa, Guen.

o. A. longa?, Guen.

* o. A. persuasa, Harv. Florida and Yokohama.

*11. A. perdita, Grote. Sanzalito.

12. A. afflicta, Grote.

A. brumosa, var., Guen. Florida.

13. A. xyliniformis, Guen. Rhode Island, Florida, \&c. *14. A. extricata, Grote. Texas? (locality not on labels).

15. A. oblinita, Sm. Abb. New York, Ohio, Nova Scotia, Canada, \&c.

\section{Section Lepitoreuma, Grote.}

1. A. rumicis, Linn.

A. diffusa, Walk. Zurich, Brussa, Turkey Ichang, Japan.

2. A. Teucoptera, Butl. Yokohama.

3. A. impleta, Walk.

A. subochrea, Grote (on label and in CheckList, p. 23. n. 66). New York.

In Grote's Revised Check-List the author (p. 4) states that there is no such species as A. subochrea. If this is the case, how did he come to label one specimen as his type of that species, a second specimen as also "Apatela subochrea, Grote," and to include it in his Check-List of 1882? It may not be a distinct species from the following, but it is certain that at one time it was so regarded by Grote.

\section{*4. A. hamamelis, Guen. United States.}

Our example is evidently a co-type, though not mentioned by Guenée, since it still bears his label; probably as it has no abdomen he thought it not worth recording under the description.

*5. A. hasitata, Grote. United States. 
Mr. A. G. Butler on the Genus Acronycta.

*6. A. dentata, Grote. United States.

*7. A. increta, Grote. New York.

*8. A. dissecta, Grote. Philadelphia, New York, Kansas.

*9. A. clarescens, Guen. Trenton Falls, New York, Nova Scotia.

*10. A. modica, Walk.

*A. exilis, Grote. New York and Texas.

*11. A. spinigera, Guen.

*A. Harveyana, Grote. New York.

*12. A. ovata, Grote. Texas.

*13. A. alborufa, Grote. New York.

*14. A. grisea, Walk. Hudson's Bay.

Section Pharetra, Hübn.

1. A. auricoma, Schiff. Zurich, Livonia, \&c.

2. A. orientalis, Mann. Bithynia.

3. A. menyanthidis, View. St. Petersburg, Berlin, \&c.

Section Triana, Hübn.

1. A. psi, Linn. Regensburg \&c.

*2. A. increta, Butl. Yokohama.

3. A. tridens, Gmel. Frankfort \&c.

*4. A. leucocuspis, Butl. Yokohama and N. China.

*5. 0 . A. lobeliar, Guen.

* q. A. thoracica, Grote. New York.

6. A. Grotei, sp. n.

A. lobeliæ, Grote (not Guen.).

Half as large again as A. lobelice, the longitudinal black streaks on the primaries slightly more elongated, but all the markings very similar: secondaries decidedly darker, with more golden gloss, the grey markings also darker. Expanse of wings, $\tau+56$ millim. (one dwarfed male 47 millim.).

New York and Kansas.

It is possible that this may be no more than a large dark form of M. Guenée's species; but it is clear that it is not so regarded in America, and therefore I name it. 
7. A. furcifera, Guen. New York.

8. A. cuspis, Treit. Germany.

9. A. maxima, Moore. Kúlú and Murree.

*10. A. ancedina, Butl. Hakodaté and Tokio.

11. A. vinnula, Grote. New Jersey.

\section{A. Smithii, sp. n.}

A. clarescens, Grote (not Guen.).

Primaries above chalky white, irrorated and clouded with sandy greyish or yellowish and grey mixed, somewhat after the manner of $A$. morula; the submedian basal black streak has somewhat the character of that of the true $A$. clarescens, only it is more elongated, sharply defined, and its upper margin is regularly tridentate; the reniform and orbicular spots are narrowly black-edged; the twin discal or postmedian lines are sigmoidal and dentate-sinuate, the outer line being partly black; the subapical longitudinal dash is vague and diffused, and the dagger-mark has a brown background, which gives it a blurred appearance; in other respects the species is like $A$. furcifera, the male having whitish and the female more or less golden-brown secondaries with the usual markings. Expanse of wings 40-45 millim.

New York and Kansas.

\section{*13. A. pauperata, Grote. United States.}

14. A. occidentalis, Grote. Rhode Island, New York, Buffalo, Kansas.

"A. furcifera, Pack." (not Guen.), on Zeller specimen.

15. A. morula, Grote. New York and Canada.

*16. A. falcula, Grote. United States.

*17. A. parallela, Grote. Colorado.

*18. A. Radcliffei, Grote. New York and Vancouver.

19. A. tritona, Hübn. New York and Florida.

20. A. hasta, Guen. "Amherst" (United States or Canada?).

*21. A. quadrata, Grote. Kansas.

Section Нувома, Hübn.

1. A. strigosa, Fabr. N. Russia, Livonia, \&c. 
Mr. A. G. Butler on the Genus Acronycta.

*2. A. nigrivitta, Hamps. Nilgiris.

3. A. divisa, Moore. Dharmsala.

Section Jocheжra, Hübn.

1. A. alni, Linn. Ausbach, Livonia, \&c.

*2. A. connecta, Grote. New York.

We also have a pretty species from Madagascar. It has probably been named by Herr Saalmüller or M. Mabille; but at present I cannot spare the time to look it up. Grote's A. funeralis is unknown to me, but (if confounded with A. americana) can hardly belong to the section Jochecera.

Section Mastiphanes, Grote.

*1. A. denticulata, Moore. Dharmsala and Sabathu.

*2. A. edolata, Grote. Arizona.

Section Merolonche, Grote.

*1. A. spinea, Grote. California.

2. A. Lupini, Behr. Mendocino.

It is possible that one or two of the Japanese and Chinese forms enumerated above may be synonymous with species described from East Siberia; but the illustrations to the 'Lepidopteren Ost-Sibiriens' and 'Reisen und Forschungen im Amur-Lande' are so poor that, without seeing examples from the Amur, it would not be possible to be certain of the identity of the species, in a genus containing so many closely related forms. 



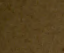



From the Annals and Magazine of Natural History,

Ser. 6, Vol. xii., July 1893.

Notes on the Genus Entomogramma as represented by the Noctuid Moths of that Group in the Collection of the British Museum. By Arthur G. Butler, F.L.S., F.Z.S., \&c.

When he founded the genus Entomogramma, M. Guenée separated the species under distinct groups in consequence of their different antennal structure; indeed, no two species of the genus as originally constituted are quite alike in their male characters, and one of them was considered by $\mathrm{Mr}$. Moore to be so dissimilar that he made it the type of a new genus. The latter, however, has no higher claim than the others to be so distinguished; and as it would be necessary for the sake of consistency to found a separate genus for every species of the original group, provided that the secondary sexual characters were taken into account, it seems preferable to regard them, as Guenée did, merely as sections of one variable genus.

The practical common sense of this mode of procedure being adinitted, Mr. Hampson has called my attention to the fact that various other species, differing only from typical Entomogramma (in the variability of the same organs in the male sex) in a similar though somewhat different manner, have been wrongly described in the genera Thermesia, Phurys, \&c. By adding these to Entomogramma I find that a tolerably gradational series is formed, evidently related throughout. The species of Entomogramma in the Museum series thus resolve themselves into eight sections, each of which differs somewhat from all the others in its male structure, whilst that of the female remains almost the same, excepting in the case of section $g$, where the female is the modified sex. These sections will now stand as follows :-

Entomogramma, Guen.

Section $a$. Taramina, Moore.

Males with basal third of antennæ dilated, outer two thirds 
pectinated, inner two thirds with short fine deflexed ciliations ; basal area of primaries and basi-internal area of secondaries below densely clothed with hair; femora and tibiæ also densely hairy.

\section{Entomogramma torsa.}

Entomogramma torsa, Guenée, Noct. iii. p. 204. n. 1605 (1852).

Java, Ceylon, Nilgiris, N. India. Type in Coll. B. M.

\section{Section $b$.}

Antennæ dilated as in Section $a$, but biseriate-denticulated and fasciculated; under surface of wings much less hairy; legs quite different, the anterior pair emitting a large fanshaped pencil of hair at the origin of the femur, the latter with a short fringe below, the tibia thickly covered at the back with appressed hairy tufts; remaining legs not hairy, the middle tibiæ coarsely scaled in front and spiny, the posterior tibiæ spiny.

\section{Entomogramma pardus.}

Entomogramma pardus, Guenée, Noct. iii. p. 205. n. 1606 (1852).

Hypopyra anteponens, Walker, Lep. Het. xiv. p. 1323. n. 2 (1857).

Remigia venusta, Walker, l. c. Suppl. iii. p. 1011 (1865).

S. Africa, Natal, Delagoa Bay, Sierra Leone. B. M.

\section{Section $c$.}

Antennæ very slightly dilated towards the base, with coarse biseriate ciliations, hardly amounting to denticulation; the legs rather more spiny than in Section $b$.

\section{Entomogramma mediocris.}

Entomogramma mediocris, Walker, Lep. Het. Suppl. iii. p. 949 (1865). Remigia decora, Walker, l. c. p. 1015 (1865).

Remigia antica, Walker, l. c. p. 1016 (1865).

South India. Types in Coll. B. M.

\section{Section $d$.}

Antennæ regularly ciliated in the male, front and hind legs densely hairy.

\section{Entomogramma fautrix.}

Entomogramma fautrix, Guenée, Noct. iii. p. 204. n. 1604 (1852).

Silhet, Sikkim, Mussoorie, Kangra, Khasia Hills, Nilgiris, Andamans. Type in Coll. B. M. 


\section{Section $e$.}

Antennæ? The female with all the tibiæ fringed externally; second joint of palpi elongated, thickly fringed with dense scales at the back.

\section{Entomogramma subcostalis.}

Thermesia subcostalis, Walker, Lep. Het. Suppl. iii. p. 1059 (1865).

Moulmein. Type in Coll. B. M.

\section{Entomogramma ussuriensis.}

Remigia ussuriensis, Bremer, Bull. Acad. Sci. St. Pétersb. iii. p. 587.

Japan. In Coll. B. M.

\section{Section $f$.}

Second joint of palpi arched at the back, but not densely fringed as in Section $e$. Antennæ of male with short delicate ciliations; legs almost naked, the front and middle tibiæ alone being partly fringed with hair externally.

\section{Entomogramma nigriceps.}

․ Renodes nigriceps (as ơ), Walker, Lep. Het. xv. p. 1595. n. 6 (1858).

3. Herminia? nigrifrontalis (as P), Walker, l. c. xvi. p. 258 (1858).

Aden, Abyssinia, Sierra Leone, Natal, South Africa. Types in Coll. B. M.

\section{Var. pallidula.}

Renodes pallidula, Butler, Ann. \& Mag. Nat. Hist. 1875, vol. xvi. p. 409. n. 91.

Natal. Type in Coll. B. M.

\section{Entomogramma melanocephala.}

Poaphila melanocephala, Hampson, Il. Typ. Lep. Het. viii. p. 82, pl. exlvi. fig. 9 (1891).

Var. Poaphila marmorea, Hampson, l. c. fig. 7 (1891).

Nilgiris. Types in Coll. B. M.

\section{Entomogramma fuscescens.}

Thermesia fuscescens, Walker, Lep. Het. Suppl. iii. p. 1054 (1865).

Thermesia obumbrata, Walker, $l$. $c$.

Thermesia morosa, Walker, l. c. p. 1055 (1865).

Scambina? larvata, Walker, l. c. p. 1119 (1865).

Natal (Gueinzius). Types in Coll. B. M. 


\section{Entomogramma enervis.}

Phurys enervis, Swinhoe, Trans. Ent. Soc. 1890, p. 231. n. 352, pl. viil, fig. 8.

Rangoon. Type in Coll. B. M.

\section{Section $g$.}

Female with the second joint of the palpi broadly fringed both in front and at the back with compressed hair-scales, giving it a wedge-shaped form.

\section{Entomogramma obliqua.}

Phurys obliqua, Moore, P. Z. S. 1867, p. 80.

Burma and Sikkim. In Coll. B. M.

\section{Section $h$.}

Second joint of palpi in male broadly fringed and compressed.

\section{Entomogramma oblita.}

Thermesia oblita, Moore, Descr. Ind. Lep. Atk. ii. p. 176 (1882).

Khasia Hills and Chinn Hills. In Coll. B. M.

Mr. Hampson also refers the Thermesia rivulosa of Walker to Entomogramma; but I think it differs so considerably as hardly to warrant its being considered a section of this genus. Both sexes have the third joint of the palpi extremely short, much more so even than in $E$. pardus; the legs are rather more hairy than in Sections $f$ and $g$; the antennæ of the male are densely but finely fringed on the inside with short ciliations, and at regular intervals emit single longer hairs on both sides; the secondaries of this sex also have the abdominal border expanded and broadly fringed with long hair towards the base. The button-like third joint of the palpi in

th sexes redeems this genus from the charge of being based solely on secondary sexual characters, and therefore I propose to call it Blasticorhinus. 



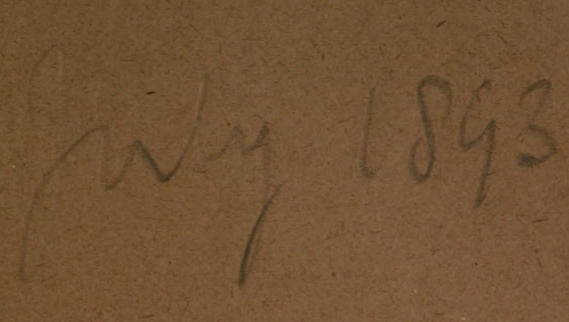

1
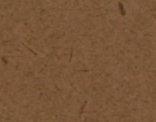


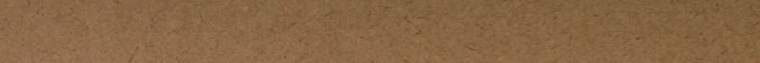

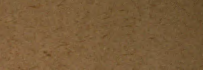

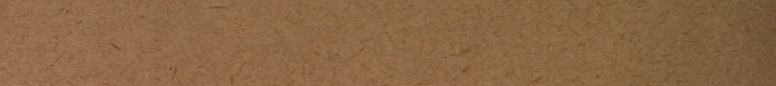

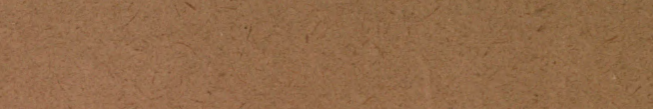


From the Anvals and Magazine of Natural History,

Ser. 6, Vol. xii., July 1893.

List of Insects collected by Miss Elizabeth Taylor in Western North America in the Summer of 1892. By ARTHUR G. Butler, F.L.S., F.Z.S., \&c., and W. F. KirbY, F.L.S., F.E.S., \&c.

\section{LEPIDOPTERA. By A. G. Butler.}

Most of the species recorded in the following list were obtained on the Slave River in the months of June and July. The collection is of interest as extending our knowledge of the range of species hitherto received from the Rocky Mountains, California, \&c. Two species are described as new to science.

Of ButTERfLIEs twenty-three species are in the collection, of which ten belong to the Nymphalidæ, four to the Lycænidæ, six to the Papilionidæ, and three to the Hesperiidæ.

1. Anosia plexippus.

Papilio plexippus, Linnæus, Mus. Lud. Ulr. p. 262 (1764).

. Winnipeg, Manitoba, 11th September. 


\section{Limenitis arthemis.}

Papilio arthemis, Drury, Ill. Exot. Ent. ii. pl. x. figs. 3, 4 (1773).

Fort Simpson, Mackenzie River, 9th July, and Fort Good Hope, 18th July.

3. Argynnis atlantis.

Argynnis atlantis, Edwards, Proc. Acad. Nat. Sci. Phil. 1862, p. 54; Butt. N. Amer., Arg. pl. v. (1868).

Fort MacMurray, Athabasca River, 17th August.

\section{Brenthis myrina.}

Papilio myrina, Cramer, Pap. Exot. ii. pl. clxxxix. B, C (1779).

Rapids of the Drowned, Slave River, 1st July, and Fort Good Hope, 18th July.

\section{Brenthis freja.}

Papilio freja, Thunberg, Diss. Ins. Suec. ii. p. 34, pl. v. fig. 14 (1791).

Fort Good Hope, 18th July.

We have this species in the Museum from Repulse Bay.

\section{Brenthis bellona.}

Papilio bellona, Fabricius, Syst. Ent. p. 517. n. 317 (1775).

Rapids of the Drowned, 29th June.

\section{Phyciodes morpheus.}

Papilio morpheus, Fabricius, Syst. Ent. p. 529. n. 370 (1775).

Rapids of the Drowned, 29th June.

\section{Phyciodes gorgone.}

Dryas reticulata gorgone, Hübner, Samml. exot. Schmett. vol. i. pl. xl. (1806-16).

Rapids of the Drowned, 28th June.

\section{Eneis bore.}

Papilio bore, Esper, Eur. Schmett. i. 2, pl. c. fig. 1, pl. cviii. fig. 1 (1790).

Rapids of the Drowned, 28th June.

10. Cœnonympha inornata.

Cononympha inornata, Edwards, Proc. Acad. Nat. Sci. Phil. 1861, p. 163.

Carberry, Western Manitoba. 


\section{Everes comyntas.}

Polyommatus comyntas, Godart, Enc. Méth. ix. p. 660. n. 147 (1823).

Rapids of the Drowned, 29th June.

\section{Cupido lygdamus.}

Polyommatus lygdamus, Doubleday, Entomologist, i. p. 209 (1842).

Athabasca River, 5th June.

13. Plebeius podarce.

Lycana podarce, Felder, Reise der Nov., Lep. ii p. 282. n. 359, pl. xxxv. figs. 22,23 (1865).

Rapids of the Drowned, 1st July.

\section{Plebeius Scudderi.}

Lycana Scudderi, Edwards, Proc. Acad. Nat. Sci. Philad. 1861, p. 164.

East bank of the Mackenzie River, 30 miles north of the Arctic circle, 18th July.

\section{Colias occidentalis?}

Colius occidentalis, Scudder, Proc. Bost. Nat. Hist. Soc. ix. p. 109 (1862).

q var. ? Carberry, Western Manitoba.

This specimen has an orange flush on the primaries and is not unlike some females of $C$. ariadne excepting in its superior size.

\section{Colias interior?}

Colias interior, Scudder, Proc. Bost. Nat. Hist. Soc. ix. p. 108 (1862).

․ Fort Good Hope, Mackenzie River, 18th July.

It is quite possible that I have failed rightly to identify the two preceding females of Colias; in fact I do not believe that anyone but Mr. W. H. Edwards could form any definite opinion respecting them.

\section{Ganoris hulda.}

Pieris hulda, Edwards, Trans. Am. Ent. Soc. ii. p. 370 (1870).

Rapids of the Drowned, 29th and 30th June; Pulo River, 31 miles south-west of the Mackenzie Delta, 15th July.

We have specimens of this species in the Museum from British Colombia.

18. Ganoris pallida.

Pieris pallida, Scudder, Proc. Bost. Nat. Hist. Soc. viii. p. 183 (1861).

Winnipeg, Manitoba, 11th September. 
19. Euchlö̈ simplonia.

Pontia simplonia, Freyer, Beitr. Schmett. ii. pl. lxxiii. fig. 2 (1829).

Rapids of the Drowned, 29th June.

A second example of this species was in the "Zeller" collection from Colorado labelled Anth. lanceolata. We have no authenticated $E$. lanceolata, Boisd., in our collection; but the species so labelled is identical with $E$. simplonia. From $E$. ausonides, to which it is closely allied, it differs chiefly in its inferior size and the smaller and narrower white markings on under surface of secondaries.

\section{Papilio turnus.}

Papilio turnus, Linneus, Mant. Plant. p. 536 (1771).

Banks of Athabasca River, 3rd June; Rapids of the Drowned, Slave River, 26th and 27th June and 1st July.

\section{Erynnis colorado.}

Pamphila colorado, Scudder, Mem. Bost. Soc. ii. p. 349, pl. x. figs. 1618, pl. xi. figs. 1, 2 (1874).

$\delta$. Rapids of the Drowned, 29th and 30th June.

$$
\text { 22. Adopoea, ? sp. }
$$

A single somewhat broken and headless example of a species apparently allied to $A$. hylas, Edw., but with the ground-colour of the wings almost black.

Carberry, Western Manitoba.

\section{Thanaos martialis.}

Nisoniades martialis, Scudder and Burgess, Proc. Bost. Nat. Hist. Soc. xiii. p. 291, fig. 5 (1870).

Rapids of the Drowned, 29th June.

Of Moths twenty-two species were obtained, of which one is a Sphingid, four are Noctuæ, and the remainder Geometræ; of these the Noctuæ are the most interesting and are, fortunately, in the best condition.

\section{Hemaris buffalvensis.}

Hamorrhagia buffaloensis, Grote and Robinson, Ann. Lyc. Nat. Hist New York, viii. p. 437, pl. xvi. figs. 18, 19 (1867).

Banks of the Slave River, 26th June. 


\section{Acronycta lepusculina.}

Acronycta lepusculina, Guenée, Noct. i. p. 46. n. 55 (1852).

Fort Good Hope, Mackenzie River, near the Arctic circle, 18th July.

\section{Syneda petricoln.}

Euclidia petricola, Walker, Lep. Het. xiv. p. 1462. n. 8 (1857).

Rapids of the Drowned, 1st July.

The type of this species was from the Rocky Mountains. It is like a small pale form of $S$. divergens, Behr., and the markings of the secondaries vary in the same way, the commashaped discocellular black dash being either isolated or connected by a bar to the submarginal band.

\section{Euclidia annexa.}

Euclidia annexa, H. Edwards, Entom. Amer. vi. p. 115 (1890).

Banks of the Slave River, 26th June; Rapids of the Drowned, 28th June and 1st July.

The type specimen and others collected with it were obtained in Oregon by Lord Walsingham.

\section{Euclidia cuspidea.}

Drasteria cuspidea, Hübner, Samml. exot. Schmett. Zutr. i. p. 16. n. 35, figs. 69, 70 .

Banks of the Slave River, 26th June; Rapids of the Drowned, 30th June.

\section{Metrocampa perlata.}

Metrocampa perlata, Guenée, Phal. i. p. 128. n. 197.

Fort Good Hope, Mackenzie River, 18th July.

\section{Cosymbia pendulinaria.}

Ephyra pendulinaria, Guenée, Phal. i. p. 414. n. 674.

Rapids of the Drowned, 2nd July.

\section{Deilinia exanthemata.}

Phalana exanthemata, Scopoli, Ent. Carn. p. 218. n. 542.

Fort Resolution, Great Slave Lake, in a marsh, at 2 P.M. on the 7th July, and at 11.15 P.M. on the 9th July.

The specimens differ in no respect from European examples; they do, however, differ somewhat from the allied D. erythemaria of the United States. 
32. Deilinia variolaria.

Cabera variolaria, Guenée, Phal. ii. p. 56. n. 987.

Fort Good Hope, Mackenzie River, 18th July.

\section{Physostegania lineata.}

Physostegania lineata, Warren in litt.

Rapids of the Drowned, 4th July at 11.30 P.м.

This being a common Californian species, it is hardly probable that it can have been overlooked by American describers, and therefore I give the name for what it is worth without diagnosis. The single example obtained is much worn, but quite recognizable.

\section{Thamnonoma marcescaria.}

Halia marcescaria, Guenée, Phal. ii. p. 92. n. 1067.

o ? Rapids of the Drowned, 4th July, at 11.30 P.M.

I believe this to be the female of $T$. marcescaria, but as we only possess one male of the species, it is difficult to decide the point. The two insects differ in slight details of pattern, which are probably of not more than sexual significance.

\section{Thamnonoma brunneata.}

Phalana brunneata, Thunberg, Diss. Ent. i. p. 9 (1784).

Fort Good Hope, Mackenzie River, 18th July.

I feel very doubtful respecting the identity of the uniformly coloured American species with the sharply lined European species; but, seeing that Dr. Packard, in his Monograph, calls the New-World form T. brunneata, I abstain from separating it without abundant material to prove its distinctness.

\section{Thamnonoma gracilior, sp. n.}

Allied to $T$. brunneata, but smaller and more slender; ferruginous; the basal area, especially of the secondaries, irrorated with blackish grey up to the median shade; the latter narrow, dusky, dentate-sinuate on the primaries and arched on the secondaries, where it is impinged upon by a more or less defined blackish lunule on the discocellulars; postmedian line blackish, sinuous, almost bracket-shaped on the primaries, limiting the external area, which is densely irrorated with blackish grey (leaving the outer borders clear in the female); the secondaries of the male are moreover more or less densely irrorated throughout; marginal line 
slender, black ; fringe tawny ferruginous; body of the male above blackish, the anal extremity with tawny bands Wings below clear tawny, with blackish markings, the median shade represented by an imperfect arched line, interrupted in the male by black discocellular stigmata; postmedian line regularly dentate-sinuate; marginal line black as above: primaries with traces of the subbasal line. Body below dark grey, sprinkled with tawny scales; the centre and anal segments pale tawny; legs creamy white.

Expanse of wings, $\delta 25$, $\$ 24$ millim.

$\delta$. Rapids of the Drowned, Slave River, 1st July; . Pulo River, near Mackenzie Delta, 15th July:

I have failed to discover any published description of this very distinct species, and therefore have ventured to name it.

\section{Tephrina, sp.}

I have not discovered any name for this species, but we have a fair series of it in the Museum from the Dalles and Rouge River, collected by Lord Walsingham. It is therefore quite possible that Mr. H. Edwards may have described it in one of his numerous papers on Californian Lepidoptera.

Rapids of the Drowned, 4th July.

\section{Tephrina, sp.}

A pair of an obscure little species in not very good condition, the female headless.

๙. Pulo River, near Mackenzie Delta, July 15th ; ?. Fort Good Hope, Mackenzie River, near the Arctic circle, July 18th.

\section{Coremia, ?sp.}

A worn male specimen, for which I have failed to find a name, from Fort Good Hope, July 18th.

\section{Odezia albovittata.}

Odezia albovittata, Guenée, Phal. ii. p. 520. n. 1757.

Athabasca River, 17th and 20th June.

\section{Eutype gothicata.}

Melanippe gothicata, Guenée, Phal. ii. p. 388. n. 1521.

Rapids of the Drowned, 26th June. 


\section{Eutype obductata.}

Cidaria obductata, Moeschler, Wien. ent. Monatschr. 1860, p. 374, pl. x. fig. 3.

Pulo River, near Mackenzie Delta, 15̃th July.

\section{Pseudosiona, gen. nov.}

Form of wings and short palpi as in Siona; pattern and neuration similar to Eubolia, the subcostal branches of secondaries (veins 6 and 7) being emitted separately; discoidal cell much longer.

'Type Pseudosiona Taylori.

43. Pseudosiona Taylori, sp. n.

Greyish white; the wings being white, densely irrorated with grey, with a darker spot on the upper discocellulars and an oblique stripe of grey from costa near apex to inner margin on all the wings; vertex of head and base of abdomen whiter than the remainder of the body. The under surface is whiter, the irrorations less numerous but darker, the markings also darker and browner; legs brownish; venter indistinctly zoned with grey.

Expanse of wings 35 millim.

Pulo River, near Mackenzie River, 15th July, 1892.

\section{Ochyria designata.}

Phalana designata, Hufnagel, Berl. Mon. iv. p. 612.

Rapids of the Drowned, 1st July.

\section{Larentia incursata.}

Geometra incursata, Hübner, Eur. Schmett. Geom. fig. 351.

Rapids of the Drowned, 1st July.

\section{COLEOPTERA.}

Of the two Coleoptera obtained by Miss Taylor, Mr. C. O. Waterhouse has given me the following note:-

"A single specimen of one of the Elateridæ-Corymbitesvery near $C$. ceripennis, Kirby, but with rather longer elytra; possibly distinct. I have not, however, material to enable me to determine it at present. This was taken at the Great Rapids, Athabasca River, on June 9th, 1892.

"The other is Upis ceramboides, L., which has a wide geographical range, occurring in Saskatchewan \&c. This was taken on the banks of the Slave River, June 6th." 


\section{HYMENOPTERA, RHYNCHOTA, NEUROPTERA, AND ORTHOPTERA. By W. F. KIrby.}

Only a few species of these orders were obtained, and in most cases only single specimens. Some of these belong to well-known and widely distributed North-American species; but several of the remainder belong to imperfectly studied groups, in which the genera only can be determined with certainty from the materials before us. Most of the specimens were taken at Carberry, Western Manitoba, on August 4, 1892.

\section{HYMENOP'TERA.}

\section{Nematus erythrogaster (?).}

Nematus erythrogaster, Norton, Proc. Ent. Soc. Philad. iii. p. 8 (1864); Trans. Amer. Ent. Soc. i. p. 205 (1867).

Carberry, Aug. 4, 1892.

Norton's species is recorded from the United States and Canada. His type was from Massachusetts.

\section{Sirex albicornis.}

Sirex albicornis, Fabr. Spec. Ins. i. p. 419. n. 9 (1781).

Carberry, Aug. 4, 1892.

Widely distributed throughout the northern part of North America, being met with from Newfoundland to Vancouver's Island.

\section{Sirex bizonatus.}

Sirex bizonatus, Steph. Ill. Brit. Ent., Mand. vii. p. 114, pl. xxxvi. fig. 2 (1835).

Carberry, Aug. 4, 1892 ; Athabasca River, Aug. 15, 1892. As common and widely distributed a species as the last.

\section{Ichneumon, sp.}

Carberry, Aug. 4, 1892.

$$
\text { 5. Mesoleptus, sp. }
$$

Carberry, Aug. 4, 1892.

\section{Mimesa borealis.}

Mimesa borealis, Pack. Proc. Ent. Soc. Philad. vi. p. 408 (1867).

Carberry, Aug. 4, 1892.

Descrihed by Packard from Canada. This species will 
ultimately require a new name, unless it has already been redescribed in America, as it is quite distinct from $M$. borealis, Smith, a black insect from Labuan, with which Dr. Packard has confounded it.

\section{Vespa maculata.}

Vespa maculata, Linn. Amœn. Acad. vi. p. 412. n. 91 (1764).

Slave River.

The commonest of the North-American wasps, and very distinct from any European species.

8. Coelioxys, sp.

Carberry, Aug. 4, 1892.

\section{RHYNCHOTA.}

1. Rhyparochromus, sp.

Carberry, Aug. 4, 1892.

\section{Cicada pruinosa.}

Cicada pruinosa, Say, Proc. Acad. Nat. Sci. Philad. iv. p. 330 (1825).

Carberry, Aug. 4, 1892.

A common North-American species.

3. Glossonotus, sp.

Carberry, Aug. 4, 1892.

\section{NEUROPTERA.}

1. Enallagma boreale.

Enallagma boreale, De Selys, Ent. Mo. Mag. xi. p. 242 (1875).

Rapids of the Drowned, June 29, 1892.

Described by De Selys from Newfoundland.

\section{Pteronarcys proteus.}

Pteronarcys proteus, Newm. Ent. Mag. v. p. 177 ?1838).

Grand Rapids, Athabasca River, June 6, 1892.

The specimens in the British Museum are from New York and Mackenzie River.

3. Isogenus frontalis.

Isogenus frontalis, Newm. Ent. Mag. v. p. 178 (1838).

Grand Rapids, Athabasca River, June 10, 1892. 
North-American Insects.

Recorded from Trenton Falls, New York, and St. Martin's Falls, Albany River, Hudson's Bay.

4. Limnophilus, sp.

Carberry, Aug. 4, 1892.

\section{ORTHOPTERA.}

1. Arphia sulphurea.

Gryllus sulphureus, Fabr. Spec. Ins. i. p. 369. n. 39 (1781).

Carberry, Aug. 4, 1892.

A common North-American species.

2. Stenobothrus, sp.

Carberry, July 11 and Aug. 4, 1892. 



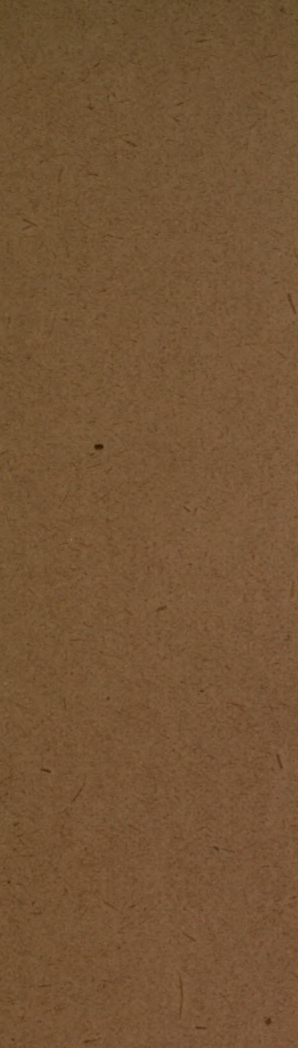



downe. 1993 

From the Annals and Magazine of Natural History,

Ser. 6, Vol. xii., Stptember 1893.

On a small Collection of Lepidoptera from Darwin Harbour, Falkland Islands. By Arthur G. Butler, Ph.D., F.L.S, F.Z.S., \&c.

THE little series of Lepidoptera of which the following is an account was obtained by Dr. W. F. Dale, and sent to Mr. J. Hartley Durrant, who forwarded it to me with the request that I would name it.

The collection contains ten species represented by about forty specimens, and is interesting as a contribution to a littleknown fauna. So far as I can judge, it seems to show greater affinity to that of Chili than to any other.

\section{Argynnis siga.}

Argynnis siga, Hübner, Samml. exot. Schmett. Zutr. figs. 677, 678 (1832).

One example.

This is the only butterfly in the collection. No Sphinges or Bombyces were obtained ; indeed, the most largely represented tribe was the Noctuites.

\section{Agrotis hispidula.}

Agrotis hispidula, Guenée, Noct. i. p. 293. n. 476 (1852).

Five examples of this somewhat variable species; it was originally described from Chili.

\section{Agrotis Dalei, sp. n.}

This insect has somewhat the aspect of a Nonagria; it has, however, very coarsely spined tibiæ and the antennæ are strongly pectinated, each pecten being finely ciliated on each side. Primaries above pale sericeous buff (almost dead gold in tint); costal half sparsely, irregularly, but distinctly speckled with black; a curved discal series of similar black flecks from near costa almost to inner margin beyond the cell; a few fine scattered black dots near outer margin and a welldefined marginal series; fringe of inner and outer margins pale cupreous or rufous-brown, traversed by two grey lines: secondaries grey, slightly darker on external border; fringe buff, shading into reddish ochreous towards apex : head and collar testaceous, the face slightly yellower; antennæ ferruginous; thorax sordid pale buff; abdomen grey, with pale ferruginous lateral and anal tufts. Primaries below smoky grey, slightly blackish at base of costa; base of median and 
submedian veins pearly opaline; costa washed with buff; an ill-defined transverse dusky discal stripe; external area pale rosy cupreous: secondaries sericeous whitish, the costal area, veins, and fringe buff, slightly rufous; a discocellular spot and five or six longitudinal dashes on the veins across the disk black: pectus whity-brown; legs rufous-brown, with ferruginous spines and whitish-tipped spurs; venter rosy, with the anal tufts slightly yellower.

Expanse of wings 43 millim.

One male of this very distinct species.

\section{Peridroma hostilis.}

Agrotis hostilis, Walker, Lep. Het. xi. p. 737 (1857).

Four examples.

I believe that this is no more than an extreme form of $P$. saucia. P. stictica, Blanch., from Chili, is quite intermediate in character between the two.

\section{Peridroma clerica.}

Agrotis clerica, Butler, Trans. Ent. Soc. 1882, p. 129. n. 27.

Three examples of this Chilian species.

\section{Leucania falklandica, sp. n.}

In marking somewhat intermediate between $L$. sinuos a of India and $L$. propria of New Zealand. Primaries above sericeous whity brown, the course of the median vein and the external borders suffused with grey; a black dot followed by a blackish spot at base of costal area; a diffused black streak, trisinuate in front, immediately above the median vein, terminating beyond the cell in a small oblique 3-shaped character; a well-defined black streak from base below the median vein, terminated by the extrabasilar line, which is much interrupted, transverse, and lunulated; a blackish dash on the inner margin also followed immediately by the same line; discal or postmedian line fine, arched inwards to costa, dentatesinuate; a slightly irregular submarginal series of blackish sagittate spots ; fringe white, traversed by two grey lines: secondaries white, slightly opalescent, the costal area silvery; veins and a rather narrow diffused external border smoky grey; fringe white, traversed internally by a smoky grey line: head and thorax whity-brown; collar greyish white, crossed at the back by an interrupted black line; tegulæ whitish at their apices; base of abdomen whitish buff, the remainder sericeous smoky greyish. Primaries below silvery 
greyish, becoming yellower on costa: secondaries white, with costa and veins buff; a diffused greyish external border; fringes as above: body below sandy buff, greyish here and there; tibial fringes slightly rufous, whitish at tips; venter sericeous.

Expanse of wings 37 millim.

\section{Eupithecia anguligera, sp. $\mathrm{n}$.}

Somewhat intermediate in character between $E$. fasciata from the Nilgiris and $E$. sibylla from Chili. Leaden grey, slightly tinted here and there with brown : primaries elongatetriangular, traversed by about ten wavy blackish lines, but extremely variable; the alternate lines, beginning with that nearest the base, blacker, and therefore better defined than the others, the fifth and seventh, representing the outlines of the central band, black, thicker than the others and acutely angulated towards costa ; the tenth line composed of more or less confluent pale-bordered blackish submarginal lunules; a marginal series of externally whitish-edged black dashes: secondaries with hardly a trace of marking from the median vein upwards; a triangular black patch at base below the cell, followed by six blackish zigzag lines, of which the first, third, and fifth are best defined and quite black upon the veins; marginal black dashes as on the primaries: thorax pale leaden grey, with darker transverse bands; abdomen much darker, with almost confluent blackish bands in the type, but extremely variable in depth of colour in a series. Under surface sericeous leaden grey; all the wings with black or blackish discocellular stigma, followed by two parallel blackish lines; the secondaries with traces of a third (subbasal) line; black marginal dashes as above.

Expanse of wings 19 millim.

A series of twenty-one examples, most of them more or less worn.

In some specimens the markings are very indistinct, in others the two black lines of the central band alone remain, with a well-defined discocellular stigma (which, in the type above described, is only shown on the under surface); in others again the outer line of the central band is only marked with black on the veins. In all these specimens, however, such markings as exist are similar in outline and similarly placed, so that it is evident that they represent only one variable species. 
8. Scoparia?, sp.

A single example in worn condition.

\section{Crambus, sp.}

Three examples of a species allied to C. vitellus of New Zealand. The latter is also described as C. sublicellus, Zell.

$$
\text { 10. Apurima, sp. }
$$

Three examples, in poor condition, of a species apparently referable to this genus. 


From the Annals and Magazine of Natural History,

Ser. 6, Vol. xii., October 1893.

Description of a new Species of the Butterfly Genus Charaxes. By Arthur G. Butler, Ph.D., F.L.S., F.Z.S., \&c.

For many years a species of the genus Charaxes has been confounded with the well-known C. ethalion of Natal and Delagoa Bay. As I have recently been through the whole of the literature relating to the genus and have failed to identify it, I now propose to describe it as

\section{Charaxes Hollandii, sp. n.}

$\delta$. Chiefly differs from C. ethalion $\delta$. (ephyra, Godt.) in the deeper excavation of the suter margin of the primaries and the longer abdominal margin of the secondaries; on the under surface, however, the wings are much richer in colouring, the black markings much more heavily delineated, and the central belt washed with silvery glaucous; the spots beyond this belt are also darker and, on the primaries, more numerous.

Expanse of wings 72 millim.

q. Above far more like a dwarfed female of $C$. imperialis than like C.ethation; blue-black, the primaries with three small lilacine spots in a triangle beyond the cell, the apex of the triangle being directed obliquely downwards towards the base of the third median branch ; below these two increasing spots of the same colour in the median interspaces; between the latter and the inner margin a bright blue band, constricted above the submedian vein; nearer to the outer margin a biangulated almost ₹-shaped series of seven spots, of which the upper six are lilacine with white centres and the seventh bright blue; central belt of secondaries bright blue; in other respects tolerably close to C. ethalion: below the wings have a glaucous gloss, especially on the paler bands, and in some respects the pattern more nearly resembles that of $C$. etheocles.

Expanse of wings 82 millim.

Sierra Leone.

I have named this pretty little species after my valued friend Dr. Holland, of Pittsburg, whose many important contributions to our knowledge of the Lepidopterous fauna of West Africa are widely known. 

Sec- 1843

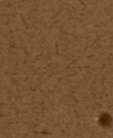

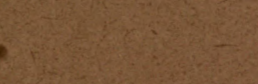

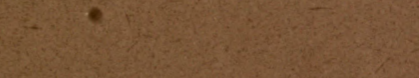

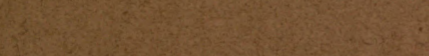

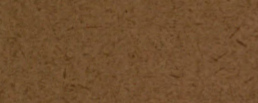

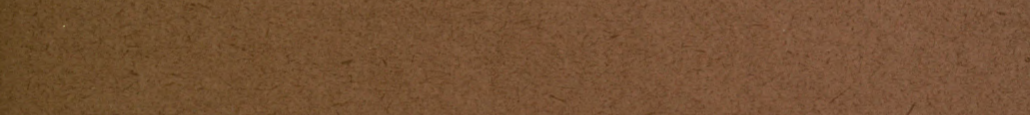
The 

On a Small Collection of Lepidoptera from Chili. By Arthur G. Butler, Ph.D., F.L.S., F.Z.S., \&c.

A short time since Herr G. Ruschewegh, of Buenos Aires, wrote to ask whether I would undertake to determine a series of Chilian Geometræ, conditionally on the specimens being presented to the British Museum; to this I agreed, and during September a box of Lepidoptera in papers came to hand, some of which, indeed, are not Geometræ and several of which, when set up, I found to be in such bad condition as to be unrecognizable. The latter are numbered respectively as follows:-Deltoids (nos. 12, 78, and 120), Geometræ (nos. 17, 61, 63 in fragments, 111, 137, and 147), these nine examples being all worn, rubbed, and more or less broken. Herr Ruschewegh forwarded with the specimens a letter, in which he proposed a number of names for the new species, the majority of which are, however, so unclassical in character that it would not be possible to employ them. The following is a catalogue of all the recognizable species:-

\section{Hepialidæ.}

\section{Dalaca subfervens, Butler.}

Dalaca subfervens, Butler, Trans. Ent. Soc. 1882, p. 25 . n. 39.

In my account of the Bombyces of Chili I recognized six species of Dalaca, five of which Mr. Hampson has since put together under the name of $D$. pallens, Blanch.: breeding alone will decide whether he is right in so doing; at present, judging from the extraordinary variability of many of the Chilian Lepidoptera, it is quite as possible as it is at present unproved.

\section{$\mathrm{N}$ O C T U}

\section{Peridroma saucia, Hübner.}

Peridroma saucia, Hübner, Samml. eur. Schmett., Noct. fig. 378.

The examples are links between typical $P$. saucia and P. hostilis and are labelled $\mathrm{D}, \mathrm{F}, \mathrm{H}$, and $\mathrm{C} 6$ respectively. 
3. Leucania impuncta, Guenée.

Leucania impuncta, Guenée, Noct. i. p. 83. n. 117 (1852).

Labelled "E, F. Oxyacanthæ."

4. Leucania unipuncta, Haworth, var. separata, Walker.

Leucania unipuncta, Haworth, var. separata, Walker, Lep. Het. xxxii. p. 626 (1865).

Labelled G 3.

5. Plusia gammoides, Blanchard.

Plusia gammoides, Blanchard, in Gay's Fauna Chilena, vii. p. 84. n. 1, pl. vi. fig. 11 (1854).

Labelled A.

6. Plusia chilensis, Butler.

Plusia chilensis, Butler, Trans. Ent. Soc. 1882, p. 138. n. 43.

Labelled B.

As already noted, the Deltoid Noctuæ are in too poor condition for recognition.

The remainder of the collection consists wholly of Geometræ. I have followed Mr. Warren's recent arrangement of this group.

G E O M E T R Æ.

7. Psilaspilates cavifasciata, Butler.

Panagra cavifasciata, Butler, Trans. Ent. Soc. 1882, p. 384. n. 65.

Numbered 55.

8. Psilaspilates ceres, var., Butler.

Lozogramma ceres, var., Butler, T1ans. Ent. Soc. 1882, p. 383. n. 63.

Numbered 66.

9. Psilaspilates venata, Butler.

Liodes venata, Butler, Trans. Ent. Soc. 1882, p. 382. n. 62.

Numbered 151.

It will be seen that Mr. Warren has associated together under a new genus of his own three species which I regarded as belonging to different recognized genera; it is possible that, in spite of their different aspect, they may be strictly congeneric; it is also not improbable that the genera to which I assigned them may not differ in essential characters, but at 
present I cannot spare time to examine into this point critically. As regards Panagra, it is certain that Walker associated together several very distinct genera under one name.

10. Pharmacis mixta, Butler.

Pharmacis mixta, Butler, Trans. Ent. Soc. 1882, p. 375, n. 52.

Labelled No. 96.

Var. seriata, Butler.

Pharmacis mixta, var. seriata, Butler, $l$. c.

Labelled Nos. 97-99.

11. Pharmacis latifasciata, Butler.

Pharmacis latifasciata, Butler, Trans. Ent. Soc. 1882, p. 377. n. 54.

Labelled No. 77.

12. Heterophleps ophiusina, var., Butler.

Heterophleps ophiusina, var., Butler, Trans. Ent. Soc. 1882, p. 423. n. 133.

Nos. 4, 134, and 155.

13. Neorumia lutea and gracilis, Bartlett-Calvert.

Neorumia lutea and gracilis, Bartlett-Calvert, Trans. Ent. Soc. 1893, pp. 216, 217.

N. lutea, typical. Nos. 86 and 87.

N. gracilis. No. 88 . This is only a suffused variety of N. lutea.

14. Anisogonia deustata, var. carnea, Butler.

Paragonia deustata, var. carnea, Butler, Trans. Ent, Soc. 1882, p. 353.

đ. q. Nos. 43, 44, 81, and 113.

Var. rosea, Butler.

Paragonia deustata, var. rosea, Butler, l.c. p. 354.

万우. Nos. 10, 27, 41, 45, 49, 59, 64.

Var. typ. deustata, Felder.

Paragonia deustata, var. typ., Felder, Reise der Nov., Lep. v. pl. cxxiv. fig. 8 (1875).

万ิ. No. 18.

Var. cinerea, Butler.

Paragonia deustata, var. cinerea, Butler, l. c. p. 354. n. 22.

ơ ?. Nos. 51, 96, 106. 
Since I separated the forms of this species so many new and intermediate types have come to hand that I am forced * to the conclusion that the whole are sports of one extremely variable species.

\section{Syncirsodes valdiviana, Butler.}

Apicia valdiviana, Butler, Trans. Ent. Soc. 1882, p. 342. n. 5.

o. o. Nos. 15 and 16.

The female is larger than the male ( 48 millim.) and the ground-colour above is of a slightly greenish-cream tint; otherwise it resembles the male; the males, however, vary somewhat in the colouring of the upper surface; it is therefore possible that females having the upper surface-colouring of the typical male may occur.

\section{Euangerona valdivia, Butler.}

Euangerona valdivia, Butler, Trans. Ent. Soc. 1882, p. 359. n. 29.

Seven examples (numbered respectively $82,83,84,91,105$, 108, 155), showing somewhat similar variations to those occurring in Angerona prunaria, but duller throughout.

\section{Odontothera virescens, Butler.}

Odontothera virescens, Butler, Trans. Ent. Soc. 1882, p. 409. n. 105.

No. 112.

\section{Odontothera debilis, Butler.}

Odontothera debilis, Butler, Trans. Ent. Soc. 1882, p. 410.n. 106.

๙. No. 95. The primaries greener and the secondaries greyer than the type of the female.

\section{Digonis aspersa, Butler.}

Digonis aspersa, Butler, Trans. Ent. Soc. 1882, p. 361. n. 31.

No. 13.

\section{Microclysia Philippii, Bartlett-Calvert.}

Microclysia Philippii, Bartlett-Calvert, Trans. Ent. Soc. 1893, p. 200.

No. 75 .

\section{Mcandrogonaria (Warren) valentina, sp. n.}

Primaries with the basal third ferruginous; a short white oblique line immediately followed by a quadrate spot on the costa ; central area bounded and crossed by three oblique dark lines, angulated towards costa, equidistant on inner margin; 
the two inner ones rufous brown, enclosing a white belt striated with ferruginous, and divided by rufous-brown veins; the third line slaty grey; the interval between the second and third lines also white, similarly interrupted to the belt already mentioned, but interrupted below the subcostal vein by a patch of greyish coffee-brown; the costal extremities of all three lines commencing in oblique quadrate ferruginous spots, separated by similarly shaped white spots, one of which also follows the third line; external third coffee-reddish, slightly suffused with greyish and sericeous; an almost triangular patch of white, striated with fine lines of the ground-colour, tapering from costa; fringe interrupted by lunate white spots: secondaries sericeous white, traversed from about the middle of abdominal margin by two subparallel well separated grey lines, which become indistinct and are angulated towards costa; the inner line less defined than the outer; abdominal and external areas suffused with rosy coffee-brown, darkest at anal angle; fringe rufous brown, interrupted by white lunules: body ferruginous, the abdomen sericeous and paler than the thorax. Wings below paler than above, with the markings more sharply defined; the apical patch and costa of the primaries ochreous; the basal area whitish; the secondaries almost like the primaries in character, sparsely striated with ferruginous : the frons and palpi deep ferruginous; the body whitish, densely irrorated with ferruginous at the sides; the legs white, clouded with ferruginous externally and regularly spotted with dark rufous brown. Expanse of wings 35 millim.

No. 140.

The form of this species corresponds with that of my Azelina corticalis, but the pattern and colouring are unique.

\section{Perusia precisaria, Herrich-Schäffer.}

Perusia precisaria, Herrich-Schäffer, Auss. Schmett. fig. 415. co ㅇ. Nos. 1 and 2.

\section{Casbia lapidea, Butler.}

Tephrina lapidea, Butler, Trans. Ent. Soc. 1882, p. 378. n. 56.

No. 3. I think this insect would have been better left in Tephrina than in Casbia; but it is more convenient for purposes of reference to follow Warren's arrangement.

24. Scordylia vittata, Philippi.

Euclidra vittata, Philippi, Linnæa Entom. xiv. p. 295. n. 32 (1860).

No. 133. I cannot follow Warren in calling this genus 
Heterusia until it has been decided, first, that Devanica, Moore, shall supersede Eterusia (sic) of Hope; and, second, that the species of Scordylia are congeneric with the very dissimilar species figured by Hübner as the type of his genus. Mr. Warren appears to have followed Felder in adopting Heterusia, Hübner, for the species of Scordylia.

\section{Eucosmia exacta, Butler.}

Scotosia exacta, Butler, Trans. Ent. Soc. 1882, p. 415. n. 114.

No. 8.

26. Anchiphyllia (Warren) olivacea, Butler.

Sarracena olivacea, Butler, Trans. Ent. Soc. 1882, p. 421. n. 129.

No. 30. Warren associates under one name S. olivacea, pellicata, and declinata, ignoring marked differences in form of wing and pattern. Of course this is a purely arbitrary decision, not supported by a particle of evidence. Although it is possible that the three types may eventually prove to be seasonal forms or alternating generations of a single species, it is, to say the least, not usual for three types of wing-outline combined with three types of wing-banding to occur in one species ; therefore, until their identity has been proved or disproved by breeding, I shall not bow to Mr. Warren's decision.

27. Phyllia triangularia, Blanchard.

Phyllia triangularia, Blanchard, in Gay's Fauna Chilena, vii. p. 89. n. 1, pl. vii. fig. 5 (1852-54).

Nos. 9, 23, and 116. Varying slightly in tint; my $P$. cinerescens is probably a well-defined variety of the same.

\section{Chlorotimandra viridis, Butler.}

Chlorotimandra viridis, Butler; Trans. Ent. Soc. 1882, p. 369. n. 45. ๙⿱ ? . Nos. 57 and 62.

\section{Rhopalodes virescens, Philippi.}

Tomopteryx virescens, Philippi, Stett. ent. Zeit. xxxiv. p. 315. n. 3, pl. ii. fig. 7 (1873).

\section{ช̃. No. 78.}

Warren placed this under two genera, believing probably that I had wrongly identified Philippi's species; now that we have the male, it is perfectly evident that my identification was correct. 


\section{Tomopteryx loeta, Philippi.}

Tomopteryx lata, Philippi, Stett. ent. Zeit. xxxiv. p. 314. n. 2, pl. ii. fig. $6 a$ (1873).

q. No. 36 .

The female is larger than the male and has the welldeveloped secondaries of all females of the family.

\section{Tomopteryx esmerald́a?, Bartlett-Calvert.}

? Rhopalodes esmeralda, Bartlett-Calvert, Trans. Ent. Soc. 1893, p. 218.

No. 31.

1 have not been able to find any specimen in the collection answering to the description and believe it cannot have been forwarded with Mr. Bartlett-Calvert's other species; the specimens before me are not in good condition, but probably represent the species, the only additional character being a small triangular white spot at the end of the cell of primaries with a dusky spot below it.

\section{Tomopteryx botulata, Felder.}

Tomopteryx botulata, Felder, Reise der Nov., Lep. v. pl. cxxxi. fig. 18.

No. 46. Should be the type of a different genus.

33. Hoplosauris heliconoides, Butler.

Hoplosauris heliconoides, Butler, Trans. Ent. Soc. 1882, p. 399. n. 87.

No. 118.

\section{Hoplosauris valeria, sp. $\mathrm{n}$.}

ð. Primaries above greyish brown, traversed by numerous irregular darker lines; an irregular trifid pyramidal black spot, its base resting upon the inner margin near the base, its outer edge bordered with white; just beyond this two illdefined blackish, angulated, parallel, sinuous stripes; central belt white internally, its outline represented by subconfluent black spots, the inner edge subangulated and sinuous, the outer edge running obliquely from costa to upper radial, where it is acutely angulated, from which point to inner margin it is regularly, deeply, but unequally bisinuated to inner margin; it is also bounded externally by a narrow whitish band intersected by a brown line; a sinuous white submarginal stripe, internally bounded and partly interrupted in the centre by four black spots, of which the first two are fusiform and larger than the others; a marginal series of numerous black dots: secondaries sericeous white, slightly brownish at apex. Body above grey-brown, the thorax dark; 
below altogether paler than above; the markings almost obliterated. Expanse of wings 32 millim.

No. 53.

\section{Hoplosauris? edelmira, sp. n.}

$\delta$. Bronzy greyish brown; primaries crossed by numerous irregular black lines; the central region darker from about the seventh to the tenth line, indicating a central belt, the outer edge of which commences in an irregular 3 -shaped character, and is thence regularly undulated to inner margin; a small transverse elliptical white spot at end of cell ; a regularly dentate-sinuate submarginal whitish line, immediately beyond which towards apex are two or three partly confluent black spots; a marginal series of numerous black dots : secondaries and under surface sericeous whitish; the primaries browner in certain lights and showing traces of the markings of the upper surface. Expanse of wings 40 millim.

Nos. 145 and 152.

\section{Epirrhö̈ Edmondsii, Butler.}

Fidonia Edmondsii, Butler, Trans. Ent. Soc. 1882, p. 385. n. 68.

No. 38 .

37. Epirrhoë decipiens, Butler.

Coremia decipiens, Butler, Trans. Ent. Soc. 1882, p. 412. n. 109.

No. 22.

38. Cidaria ceres, Butler.

․ Cidaria ceres, Butler, Trans. Ent. Soc. 1882, p. 417. n. 119.

2 . Nos. 29 and $29 x$.

The male differs from the female in its inferior size, the primaries either greenish or reddish towards outer margin, and with a submarginal band dentated or zigzag externally, either red-brown or slaty grey, and sometimes separated into contiguous spots.

\section{Cidaria corticalis, Butler.}

Anticlea corticalis, Butler, Trans. Ent. Soc. 1882, p. 411. n. 108.

No. 136.

I can hardly think this species rightly placed in Cidaria; it bears no resemblance to any other species referred to that genus by Mr. Warren. 
40. Cidaria misera, Butler.

Cidaria misera, Butler, Trans. Ent. Soc. 1882, p. 415. n. 117.

No. 154 .

\section{Cidaria adela, sp. n.}

Sericeous greyish brown; the general aspect of $C$. squalida of New Zealand, but the primaries more acuminate at apex, the secondaries with irregularly dentated outer margin; the central belt of the primaries having more nearly the outline of $C$. capitata of Europe, but black-edged, crossed by black lines, and enclosing a black discocellular dot followed by a whitish nebula; beyond this belt one or two ill-defined crinkled transverse lines, followed by a series of black or blackish spots, bounded by submarginal white lunules; nervures on external area pale sandy brownish, interrupting an externally white-edged black undulated marginal line; fringe black-brown at base, white, tipped and spotted with blackish brown, externally: secondaries paler than primaries excepting towards outer margin; the external area being bounded internally by two or three scarcely discernible parallel lines slightly darker than the ground-colour; on the abdominal margin these lines terminate as blackish lunules; a short white dash at anal angle, being the last of a series of badly defined submarginal spots; marginal line and fringe as in primaries. Wings below with black oblique discocellular dashes or spots, one in each wing; an angulated zigzag blackish discal line and a whitish badly defined zigzag submarginal line; marginal line and fringe almost as above; costal area of primaries and whole of secondaries irrorated with whitish; tibiæ and tarsi dark grey-brown, banded with whitish. Expanse of wings 37 millim.

Nos. 69 and 147.

42. Euphia hymenata, var., Felder.

Cidaria hymenata, var., Felder, Reise der Nov., Lep. v. pl. cxxxii. fig. 41, ․

o $q$. Nos. 141 and 143.

'The female in the present series is paler than in Felder's figure, the primaries being stramineous instead of deep ochreous. The male has shining pale copper-brown primaries varied with pale ochreous on basal area and just beyond the cell; the upper portion of the central belt is also of this colour; the latter is represented by two slightly divergent nearly straight grey stripes, the outer one of which is inter- 
rupted just beyond the cell by a white 7 -shaped character; the secondaries are sericeous, cream-coloured, acuminate at apex; the neuration is peculiar, the internal vein absent, the three median branches placed near the abdominal margin, and the lower discocellular veinlet absent; the subcostal branches spring from the end of the cell, not from a footstalk, as in the female.

I have followed Warren in calling this a species of Euphia, though the character of the male points rather to a relationship to Remodes and allied genera.

43. Spargania pastoralis, Butler.

Ypsipetes pastoralis, Butler, Trans. Ent. Soc. 1882, p. 408. n. 104.

No. 20.

\section{Spargania bellissima, sp. $\mathrm{n}$.}

Sericeous; primaries pale argillaceous brown; an irregular black-brown basal band, bounded externally by a zigzag white line; central belt irregular, white, shaded with buff in the centre and at inner margin enclosing three large irregular black-brown patches, two costal a id one crossing the median branches, also two small black markings on inner margin, connected with the latter on eacls side by a slender line; the central belt is of nearly equal width from the inner margin to the lower radial vein (vein 5), but from thence rapidly widens to costa, where it is of double the width; a large apical blackish patch, divided by an irregularly zigzag submarginal line; the latter interrupted below the black patch by an oblique patch of white and bounded internally by a broad diffused band of smoky brown; fringe pale argillaceous at base, white externally, traversed by a central grey line and regularly spotted with black: secondaries silvery grey, darkest at outer margin; a black dot at the end of the cell; fringe paler than on primaries, with smaller black spots : head and collar buff, varied with black; thorax whitish ; abdomen buff, with blackish subdorsal dots in pairs. Under surface silvery greyish; primaries with faint indications of the upper surface markings : secondaries, when examined with a lens, white, speckled with grey, crossed beyond the middle by an arched dentate-sinuate blackish line, followed by an ill-defined grey band; a black dot at the end of the cell: body below brownish; palpi black, banded with white. Expanse of wings 27 millim.

No. 132 .

I was not able to adopt one of Herr Ruschewegh's names for this very charming little moth. 
45. Psaliodes signata, Butler.

Psaliodes signata, Butler, Trans. Ent. Soc. 1882, p. 418. n. 122.

No. 124.

46. Psaliodes diana, Butler.

Cidaria diana, Butler, Trans. Ent. Soc. 1882, p. 416. n. 118.

Nos. 32 and 472.

Var. cynthia, Butler.

Cidaria diana, var. cynthia, Butler, l. c.

No. 37 .

47. Eupithecia corralensis, Butler.

Helastia corralensis, Butler, Trans. Ent. Soc. 1882, p. 406. n. 100.

․ Unnumbered.

The female is considerably larger than the male, but quite like it in colouring and pattern. 


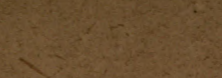

7

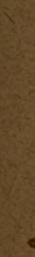

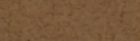

sis:

6.

3riton

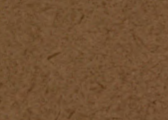

i. 1. 9

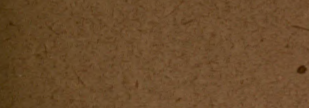
sis

ह 

Gt 1094 

From the Annals and Magazine of Natural History, Ser. 6, Vol. xiv., October 1894.

Abnormal Variability in the Antennal Characters of Cosmophila erosa, Hübn. By Arthur G. Butler, Ph.D. \&c.

THE structure of the male antennæ in moths has very frequently been used as the sole character for distinguishing genera. Mr. Hampson, however, has decided to regard all characters found only in one sex as of secondary importance, and consequently has degraded all genera which can only be separated when both sexes are known, or by the male sex apart from the female, to the rank of sections (or subgenera).

Antennal structure frequently differs widely in species which unquestionably are very nearly related, as, for instance, in Bombycia, the males of B. viminalis having the antennæ strongly pectinated, whereas in B. persimilis, which has the same pattern and coloration, they are serrate-fasciculated.

The genus Cosmophila, according to Guenée, has the 
antennæ sometimes filiform and slightly pubescent, sometimes very distinctly furnished with thick hairs, serrate and pubescent. Of $C$. erosa he says "Antennes filiformes," thus giving one the impression that in $C$. xanthindyma, indica, and auragoides they are not so. Of $C$. xanthindyma he says, "Les antennes du mâle sont nettement et fortement ciliées." The four supposed species separated by M. Guenée have precisely the same variations in form, pattern, and coloration; but at one time I believed that $C$. erosa and $C$. xunthindyma could be separated by antennal characters. Mr. Hampson, however, assured me that these also varied.

In the Museum series we have fifty-seven examples of the genus, twenty-five of which are males possessing antennæ, the result of an examination of which is as follows:-

\section{Antennce finely ciliated.}

Two specimens from St. Domingo and one from Venezuela.

1 a. Less finely ciliated.

One from São Paulo.

2. Serrate-fasciculated.

Two from Alabama, one from Australia.

\section{Pectinated.}

One from Alabama, one from Aden, one from Kulu, one from South India, one from Ceylon, four from Java.

\section{3 a. Strongly pectinated.}

One from Solun, one from the Nilgiris, one labelled simply $\mathrm{N}$. India, one from Java, one from Ceylon, one from Moreton Bay, one from Fiji, and one from the Marquesas Islands.

So far as our specimens show, the ciliated type of antenna would appear to be confined to South America, but it is connected with the pectinated type of the Old World by the intermediate serrate-fasciculated type of the United States and Australia. Indeed there is not the slightest doubt that the variation in the structural characteristics of the antennæ in this widely distributed and abundant species are individual and have no significance, so that the supposed four species of M. Guenée, as well as Walker's Cirroedia variolosa and C. edentata, represent nothing more than sports of one variable species. 
The colour-variations of $C$. erosa range from light to dark, from brightly to dull-coloured, the New-World examples, as a rule, having paler secondaries than those from the Old World; but even this character is by no means constant, the hind wings being sometimes almost white, sometimes golden ochreous, sometimes again smoky grey with white-tipped fringes; the dark lines on the primaries never seem to vary, only the ground-colouring, and this varies to an extraordinary degree; so that from the same locality and collection one may receive specimens having these wings of a nearly uniform golden ochreous tint, or divided into two nearly equal light and dark areas, always, however, showing the same silvery spot in the cell and dark (sometimes nearly black) transverse irregular lines.

Cosmophila erosa is the only species at present known to me which exhibits this abnormal variability of antennal structure, unless it should turn out that I was correct in referring the Indian specimens of Bombycia (since named by Mr. Hampson $B$. persimilis) to $B$. viminalis. This is just possible, but, judging from the constancy of our European examples in this particular, not probable.

The fact nevertheless that any one species of moth is capable of such marvellous inconstancy in the structure of the male antennæ seems quite to justify Mr. Hampson in regarding peculiarities in these organs as of secondary importance when confined to one sex, and should make all lepidopterists hesitate to use them alone for distinguishing new genera. 


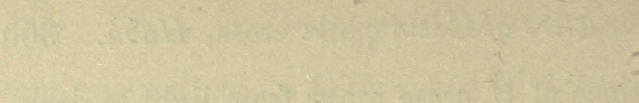

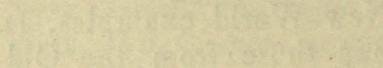

3

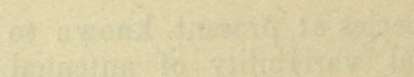

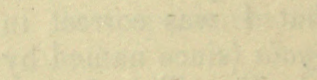

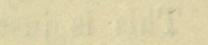

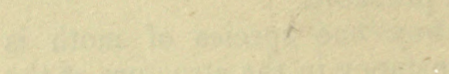




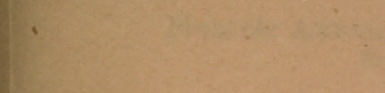

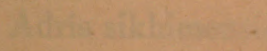

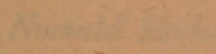

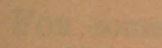

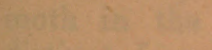

anginas

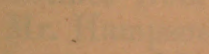

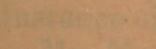

20

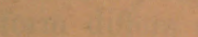

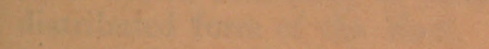

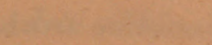

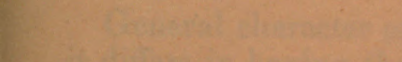

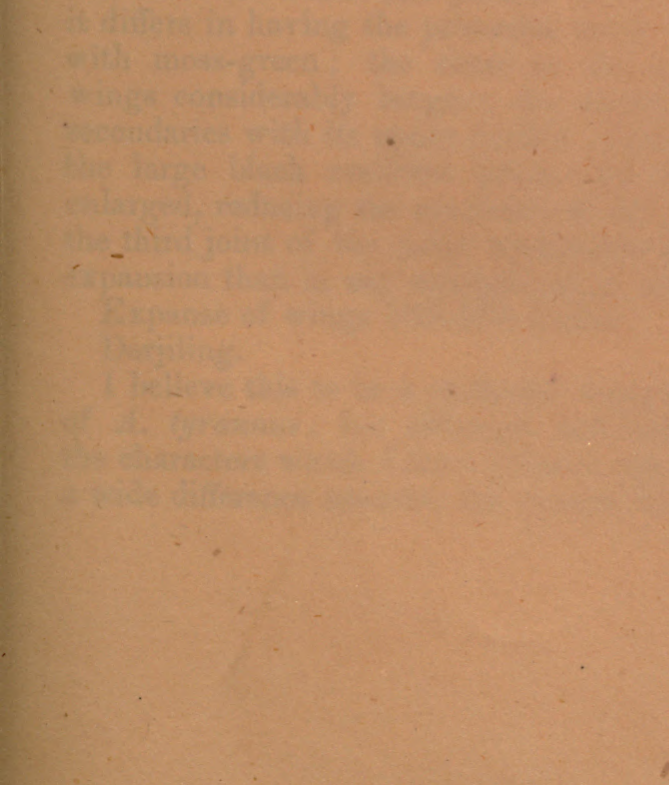



From the Annals and Magazine of Natural History, Ser. 6, Vol. xv., January 1895.

Adris sikhimensis, a new Form of the Ophiderid Group of Noctuid Moths. By A. G. Butleer, Ph.D. \&c.

For some years past we have had a single example of a moth in the Museum collection which I felt certain was distinct from the widely distributed $A$. tyrannus; but, as $\mathrm{Mr}$. Hampson was inclined to the belief that it was merely an instance of individual variation, I abstained from describing it.

Mr. Moore's collection has now added three other examples from Darjiling, clearly demonstrating the fact that the Sikhim form differs constantly in certain characters from the widely distributed form of the East. I therefore no longer hesitate to name it.

\section{Adris sikhimensis, sp. $\mathrm{n}$.}

General character and pattern of $A$. tyrannus, from which it differs in having the primaries much more largely suffused with moss-green; the sinus at the inner margin of these wings considerably longer; the curved black band on the secondaries with its upper portion constantly much wider and the large black reniform patch with its inferior lobe much enlarged, reducing the acuteness of the external indentation ; the third joint of the palpi terminates in a decidedly smaller expansion than in any example of $A$. tyrannus.

Expanse of wings 100-118 millim.

Darjiling.

I believe this to be a perfectly distinct representative form of A. tyrannus; for although individuals vary in some of the characters which I have pointed out, there is nevertheless a wide difference between the nearest forms of the two types. 

From the Annals and Magazinf of Natural History, Ser. 6, Vol. xv., March 1895.

On Charaxes azota of Hewitson, a rare Butterfly of which the Type Specimen is not in Hewitson's Collection. By A. G. Butler, Ph.D., F.L.S., \&c.

IN $1877 \mathrm{Mr}$. Hewitson described a female Charaxes under the name Philognoma azota in the 'Entomologist's Monthly Magazine,' vol. xiv. p. 82. It was obtained at Delagoa Bay by Mr. and Mrs. Monteiro, and was, apparently, so nearly related to the female of Charaxes protoclea, that it could hardly be expected that Mr. Hewitson, with his broad views respecting the variability of Butterflies, would have considered it worthy of a name. However, the fact remains that he did give it the appellation of Philognoma azota.

The following year Mr. Hewitson, in the same volume of the Magazine, described a form believed to be the male of 
what he now recognized as a true Charaxes. His type of the latter, still in his collection, was received from Nyasaland, and obtained by Mr. Thelwall.

In 1892 a specimen of the true male of C. azota was received from Delagoa Bay, through the Rev. Henri A. Junod, and in $1894 \mathrm{Mr}$. Whyte brought home a collection from Zomba in which was a male corresponding with Mr. Hewitson's example, and clearly proving that the forms from Delagoa Bay and Nyasa are as distinct as $C$. azota itself from $C$. protoclea. They may then be distinguished as follows :-

\section{C. azota.}

Tawny border of primaries without defined spots from inner margin to second median branch, whence it separates into two series of tawny spots, of which the inner row consists of five and the outer of six.

Outer tawny border of secondaries occupying nearly half the wing, its inner edge straight.

Shining central or postmedian band on under surface, especially on secondaries, very narrow; groundcolour bright rufous-brown.

Delagoa Bay.

\section{C. nyasana.}

Tawny border of primaries with well-defined black spots at centre of each division, but undivided into spots to above third median branch, so that the inner series of the furca consists of two and a half and the outer of three and a half tawny spots.

Outer tawny border of secondaries occupying only two fifths of the wing, its inner edge acutely zigzag from the median vein to the costa.

Shining central band of all the wings very broad below, the ground-colour dull smoky rufousbrown.

Nyasaland (Zomba).

C. azota was described shortly before Mr. Hewitson's death, and it is possible that the female type may never have been actually purchased from Mrs. Monteiro, who (in her work on Delagoa Bay) gives an illustration of it; at any rate, it is not in his collection, and was not there when Mr. Kirby catalogued it. The male from Nyasa, however, is in the series of Charaxes, though only labelled with its locality, and corresponds tolerably closely with the specimen brought home by Mr. Whyte, thus clearly proving the Nyasa form to be constant in its characters. 
Jarch 1895 



\title{
ON COLLECTIONS
}

\author{
$\mathrm{OF}$ \\ L E P I D O P T E R A
}

FROM

BRITISH CENTRAL A'FRICA

AND

LAKE TANGANYIKA.

BY

ARTHUR G. BUTLER, Рн.D., F.L.S., F.Z.S., etc.

[From the Proceedings of the Zoological Society of London, March 19, 1895.] 
On Collections of Lepidoptera from British Central Africa and Lake Tanganyika. By Arthur G. Butler, Ph.D., F.L.S., F.Z.S., \&c.

\section{(Plates XV. \& XVI.)}

In 1894 we received, through Mr. A. Whyte, F.Z.S., a small collection of Lepidoptera made at Zomba by Mr. J. McClounie, especially remarkable for the number of specimens of the genus Charaxes which it contained. Among these were specimens of the female of $C$. whytei (the male of which I had described and figured in the Society's Proceedings for 1893), of two previously unnamed forms, possibly distinct species, and of two undoubtedly new species, also examples of $C$. nyasana confounded by the late Mr. Hewitson with his $C$. azota.

A second series has been selected from a large consignment of Lepidoptera collected at Fwambo, Lake Tanganyika, by Mr. Alexander Carson. This is especially interesting, not only as including examples of rare species previously only received from Zomba 
and Lake Mweru, but several most startling novelties, the first of which is Junonia pavonina, a lovely new species allied to $J$. artaxica. Another very interesting Butterfly in the collection is the female of my Crenis crawshayi, clearly proving its distinctness from the allied C. concordia of Hopffer. Among the Moths of Mr. Carson's collection is one belonging to a beautiful new genus of Lithosiida bearing a most striking resemblance, in the disposition of its colours and somewhat complicated pattern, to the Agaristid genus Pais: examples of the beautiful Noctuid moth Calliodes glaucescens, previously received from Zomba only, were also among those obtained.

The following is a list of the species of which specimens were acquired:-

\section{R H OPALOCERA.}

1. Amadris whytei.

Amauris whytei, Butler, P. Z. S. 1893, p. 644.

, Zomba.

\section{Melanitis libya.}

Melanitis libya, Distant, Ann. \& Mag. Nat. Hist. ser. 5, vol. x. p. 405 (1882); Trimen, P. Z. S. 1894, p. 22, pl. iv. fig. 2.

o, Zomba.

\section{Melanitis solandira.}

Papilio solandra, Fabricius, Syst. Ent. p. 500 (1775).

Zomba.

\section{Samanta PERSPICUA.}

Mycalesis perspicuu, Trinen, Trans. Ent. Soc. London, 1873, p. 104 , pl. i. fig. 3.

Fwambo.

\section{Charaxes castor, var. flavifasciatus.}

The Eastern and Central African race of $C$. custor; having the upper-surface coloration of $C$. hrınsalii, with the general marking of the type form, from which the width of the central band principally distinguishes it; on the under surface, however, the dark markings on the basal half are greenish grey, there is a black transverse spot on the wider central white band, and the deep red band is clearly broken up into spots by whitish nervular streaks. Expanse of wings 4 inches to 4 inches 4 lines.

Zomba.

\section{Charaxes saturnus.}

Charaxes saturnus, Butler, P. Z. S. 1865, p. 624, pl. 36. fig. 1 ; , Lep. Exot. i. p. 5, pl. 2. fig. 2 (1869).

o, Zomba.

In the same collection is the female of a male insect which I have considered since 1893 to be a variety of $C$. saturnus, but respecting 
which I now have some doubt. We received the male from Sulim bin Najimb, Konde, where it was obtained by Mr. R. Crawshay. It differs from the typical form in the more falcate character of the primaries (particularly in the female), the lighter, redder basal area of the wings above, the clearer colouring of the postmedian tawny band, and the smaller black spots which traverse it; the marginal markings on all the wings extended inwards so as to form a broad band, divided into truncated ovoid tawny spots in the primaries and in the secondaries barely separated by the black veins into eight spots - the three first tiwny, bell-shaped or obconical, slightly tipped at the outer angles with white, the fourth white with orange fold, the fifth and sixth similarly coloured but quadrate internally, the two last green varied with white and lavender, connate in the female; all the tawny spots below larger and of a more salmon tint, the grey-greenish markings on basal area with more slender white margins. Expanse of wings, of 3 inches 3 lines ; ㅇ 3 inches 11 lines.

I think that this may prove to be at least a distinct race, having a restricted range in British Central Africa, and therefore I propose to call it var. laticinctus. We received a third example in the Salvin and Godman collection.

\section{Charaxes druceanus.}

o. Charaxes druceanus, Butler, Cist. Ent. i. p. 4 (Oct. 1869); Lep. Exot. p. 26, pl. x. fig. 4.

, Zomba.

The female is slightly larger and bas a broader tawny band than the male.

\section{Charaxes pollux.}

Papilio pollux, Cramer, Pap. Exot. i. pl. xxxvii. figs. E, F (1776). o, Zomba.

\section{Charaxes macciounil, sp. n. (Plate XV. fig. 1.)}

d. Allied to C. lasti : primaries with less arched costa, less sinuated outer margin, and shorter inner margin; secondaries strongly produced at anal angle, with only two tails, the first of which (at extremity of third median branch) is a mere denticle, the second (at extremity of first median branch) barely half the length of that in C. lasti; colouring deeper throughout, with all the black markings considerably heavier, the discal spots of primaries continued to below first median branch, those of secondaries forming a continuous tapering submarginal band; under surface altogether more ochreous than in $C$. lasti, the markings mostly ferruginous, the black-bordered grey markings on interno-median area of primaries reduced in size, the silver band of secondaries widened out as in C. cynthia. Expanse of wings 80 millim.

․ Extremely like Mr. Trimen's figure of C. lasti 우 (P. Z. S. 1894 , pl. v. fig. 6), but altogether deeper in colour, the black narkings heavier, the macular submarginal band much wider, 
reducing the marginal tawny border of the primaries to a series of oral spots; the secondaries somewhat produced at anal angle, with the inferior tail slightly incurved, but both tails well developed and only slightly shorter than in C. lasti: below, the wings are much paler than in the unale, the silver band of secondaries being replaced by a broad creamy stramineous belt in continuation of that on the primaries. Expanse of wings 18 millim.

Two pairs, Zomba.

This species is intermediate in character between $C$. lasti and C. cynthic.

\section{Charaxes brutus.}

Papilio brutus, Cramer, Pap. Exot. iii. pl. cexli. figs. E, F (1782). o, Zomba.

The single specimen obtained is distinctly shot with dark bronzegreen on basal area and indigo-blue on external area; the white band tapers more than usual on the primaries, the five upper spots being smaller than in most examples. This species is, however, known to vary in all these characters.

\section{Charaxes mpasana.}

Charaxes nyasana, Butler, Ann. \& Mag. Nat. Hist. 1895, xv. pp. 248-9.

Charcares azota, Hewitson, Ent. Month. Mag. xiv. p. 181 (1878). $0^{*}$, Zomba.

Hewitson's description of his Nyasa example is insufficient to enabie anyone to distinguish it from the true male of $C$. azota from Delagoa Bay: the latter is smaller than examples from Nyasaland, and on the upper surface of the primaries the reddishtawny border divides above the second median branch, the inner furca consisting of five and the outer of six spots; in the Nyasa form the border divides above the third median branch, leaving only two and a half spots of the inner furca free; the remaining divisions of the border are also marked with black spots: on the secondaries the outer red area occupies nearly half the wing in the male from Delagoa Bay, but in C. nyasana only two-fifths, in the former the inner edge of this border is nearly straight; in the latter it is zigzag. On the under surface the shiny glaucous lilacine central band in $C$. nyasana is of double the width of that in C. azota: expanse of wings in the former 95 millim., in the latter 87 millim.

C. calliclea, H. G. Smith, is an intermediate race.

\section{Charaxes leoninus, sp. n. (Plate XV. fig. 2.)}

Allied to C. nichetes, similar in form. Above deep orange, tawny in the male, paler in the female; a single or double black spot in the cell of primaries just below the subcostal vein, a transverse subcuneiform spot at end of cell, two quadrate spots beyond the cell, and three smaller spots in the median interspaces; a black zigzag discal band, diffused on both sides towards costa and bounding 
a macular increasing band of the ground-colour, which commences below the last subcostal branch with the first of four tawny spots ; below the second median branch, however, this band is much broader and unbroken; apical half of costa, apex, and external border ferruginous : secondaries crossed beyond the middle by a tapering, more or less sinuated black band continuous with the discal band of primaries; a series of annular submarginal ocelloid markings, the first six of which are nearly of equal size, the last two smaller and dotted externally with black pupilled with bluish white in the male, larger but confluent in the female: body tawny, the thorax slightly blackish. Under surface ferruginous. glaucous from the middle outwards, with dark brown markings as in $C$. nichetes on the basal half, traversed beyond the middle by a continuous, nearly straight, slate-black line, followed by an interrupted deep ferruginous zigzag stripe, which becomes indistinct on the primaries and is bounded externally towards the apex of the latter wings by whitish scaling; external border without gloss: secondaries traversed by a series of indistinet small ocelli, the last four of which (between the third median branch and the anal angle) are touched with black and pupilled with blue; immediately beyond these ocelli is a lunulate ferruginous stripe partly confluent with a diffused marginal stripe; in the female all these markings are far less defined than in the male. Expanse of wings, ot $75, \%$ 85 millim.

One pair, Zomba.

The allied $C$. nichetes appears to have been described by Dewitz as $C$. hamatus, and C. ogovensis by Dr. Holland; I cannot discover any characters by which to distinguish them.

\section{Chinaxes candiope.}

Nymphalis candiope, Godart, Enc. Méth. ix. p. 352 (1823).

, Zomba.

The single imperfect example obtained is very peculiarly coloured on the under surface, all the markings on the primaries being much less defined than usual and the secondaries being pearly dove-greyish with mere indications of the whitish markings, the postmedian lunulated band obliterated, but all the veins as usual bright green. This can, I think, bardly be more than an accidental variation, for the pattern of the upper surface is quite normal. C. viridicostatus of Aurivillius appears to be the same as C.condiope.

\section{Charaxes guderiana.}

o. Nymphalis guderiana, Dewitz, Nova Acta Akad. Naturf. Halle, 1879 , p. 200 , pl. 2. fig. 18.

o. Charaxes guderiana, Butler, P.Z. S. 1893, p. 648; Trimen, P. Z. S. 1894 , pl. v. fig. 8 .

ㅇ, Fwambo.

One brightly coloured female was obtained; males were also in the collection, but were not required for the Museum.

[6] 
15. Charaxes ethalion.

․ Charaxes ethation, Boisduval, Voy. de Deleg. ii. p. 593 (1847).

o, Zomba.

The male of this species, though probably often confounded with those of $C$. hollandi and $C$. alladinis, is common in collections.

\section{Charaxes Pheus.}

$q$ as $\delta$. Charaxes phous, Hewitson, Ent. Month. Mag. 1877, vol. xiv. p. 82.

o. Charaxes alladinis, Butler, P. Z. S. 1893, p. 648.

Now that we have received the type of $C$. alladinis in the Godman and Salvin series, I find that my former identification of the male was incorrect; the latter is a West-African insect with the basal area of the primaries bronze-greenish, marginal spots of the same colour; secondaries with white submarginal spots and a discal lunulate green streak : it appears to inhabit the Cameroons. The male described by me in 1893 is undoubtedly that sex of C. phreus.

\section{o, Zomba.}

It is a curious thing that not only did Hewitson describe and Mrs. Mouteiro figure two females as sexes of $C$. phocus ${ }^{1}$, but Dewitz did the same thing in his attempt to figure the sexes of $C$. allaclinis. I would propose the name of Charaxies rosce for Hewitson's supposed female of $C$. phoeus (which is well described by Mr. Trimen), its male doubtless would nearly resemble that sex of $C$. etheocles.

It is extremely probable that Charaxes alladinis $q$ of Dewitz (Nova Acta Leop.-Carol. Akad. Naturf. i. pl. xvii. fig. 9, 1887) is only a slight variety of $C$. rosa + ; but his Charaxes alladinis 0 (fig. 8 ) is a female allied to C. ethation and may be called $C$. dewitzi, it is perfectly distinct from C. alladinis. Charaxes ephyra, var., Dewitz (figs. 10-11), are probably the same as Mr. Trimen's recently described Charaxes manica, from which the female scarcely differs excepting on the apical border of the primuries : at any rate, without comparing specimens of both species, it would be unsafe to pronounce them distinct.

17. Charaxes whytei. (Plate XV. fig. 3 , $q$.

o. Charaxes whytei, Butler, P. Z. S. 1893, p. 649, pl. lx. fig. 2.

Charaxes selousi, Trimen, P. Z. S. 1894, p. 45, pl. vi. fig. 10.

․ Above purplish black, browner on basal area ; crossed bevond the middle by a broad pure white belt, which, however, is represented above the median vein of primaries by three elongated white spots; five other spots, sometimes lunate, in an angular series between the same belt and the costa, commencing in the second median interspace : secondaries with two spots immediately beyond and almost touching the belt upon the subcostal and radial

1 Curiously enough Mr. Trimen has failed to discover this error, which he has repeated in his 'South-African Butterflies,' vol. i. p. 344. 
interspaces ; the inferior extremity of the belt abruptly narrowed; a submarginal series of white spots, or grey spots with white centres, the last two bordered externally with lilac; still nearer to the margin an interrupted blue-edged red stripe changing to olive-green at anal angle. Below, rather more silvery than in the male and crossed by a broad white belt as above, but the angular series of spots on the primaries forming a continuous band. bounding the outer edge of the belt to submedian vein and only divided by the dark nervures ; markings beyond the belt on the secondaries better defined than in the male. Expanse of wings 67-69 millim.

Two females, Zomba.

\section{Charaxes ach emenes.}

Charaxes achomenes, Felder, Reise der Nov., Lep. iii. p. 446, pl. 59. figs. 6,7 (1867).

One much damaged example, Zomba.

It being generally decided that my name of $C$. joctste has no claim to recognition, I yield the point rather than show myself eccentric; so long as all are agreed, it matters little what name a species is known by.

\section{Charaxes Citheron.}

Charaxes citharon, Felder, Wien. ent. Monatschr. iii. p. 308, pl. 8. figs. 2, 3 (1859).

o 9 , Zomba.

\section{Charaxes bohemani.}

Charaxes bohemani, Felder, Wien. ent. Monatschr. iii. p. 321, pl. 6. fig. 3 (1859).

ơ 0 , Zomba.

One of the specinens obtained by Mr. McClounie at Zomba is of interest, inasmuch as on the upper surface it is distinctly blue, instead of green shading into blue; the outline of the basal blue area on the primaries is also irregular, a large quadrate black patch, bounded externally by three blue spots, filling the end of the cell; underneath, the ground-colour is decidedly more rufous than usual. These differences are clearly individual.

\section{Charaxes varanes.}

Papilio varanes, Cramer, Pap. Exot. ii. pl. clx. figs. D, E (1779). ơ ơ, Zomba.

\section{Euratia wahlbergi.}

Diadema wahlbergi, Wallengren, Kongl. Sv. Vet.-Akad. Handl., Lep. Rhop. Caffr. p. 27 (1857).

Euralia anthedon, var. marginalis, Butler, Ann. \& Mag. Nat. Hist. ser. 4, vol. xvi. p. 395 (1875).

․, Zomba. 


\section{Euralia mima.}

Diadema mima, Trimen, Trans. Linn. Soc. xxvi. p. 506 note, pl. xliii. fig. 7 (1869).

Two females, Zomba.

Both sexes of this fine Euralia are in the Hypolimnas group of the Godman and Salvin collection recently added to the Museum series. The species is a good copy of Amauris whytei, the Nyasa representative of $A$. albimaculata, which it doubtless mimics in Natal, as Mr. Trimen observes.

\section{Junonia artaxia.}

Junonic artaxia, Hewitson, Exot. Butt. iii. Jun. pl. i. fig. 6 (1864).

, Zomba.

\section{Jenonia Patonina, sp. n. (Plate XVI. figs. 1-3.)}

Allied to $J$. artaxia. Primaries above having the same general aspect, but brilliantly glossed all over with peacock-blue; the broad black patch from costa only represented by a diffused dark shade, with sinuous external edge, beyond end of discoidal cell; the subapical whitish bar of $J$. artaxia represented by an angulated blue band enclosing an oblique trifid snow-white streak near the costa; and halfway between this band and the end of the cell there are three or four transverse blue spots bounding the upper portion of the dark shade previously noted; a slightly irregular, but not sinuated black stripe separates the angular blue subapical band from a diffused blue marginal band which tapers along the edge of the black stripe at its upper extremity and along the margin at its lower extremity ; fringe dull white, grey towards apex and external angle and traversed throughout by a dusky line flecked with black: secondaries brilliant peacock-blue in the male, and the centre of the wing to beyond the middle blue in the female; ocelli of nearly equal size, a little brighter in colouring than in J. artaxia; 'submarginal lines wider and blacker : body slightly darker. Under surface very dissimilar, olive-brown; the pattern of the primaries nearly as in $J$. nachtigalii, but only glossed with purple below the cell ; the four transverse stripes sharply defined and whity-brown, slightly glossed with blue below the median vein ; an apical costal cuneiform whitish patch, partly edged with diffused white spots towards costal margin ; ocelli small, olivaceous grey, with yellowish iris flecked internally with red; submarginal line slender, blackish, irregularly undulated: secondaries somewhat paler and greyer, especially towards abdominal margin; a sharply defined, blackishedged, central clear yellowish-white stripe from costa to anal angle; two other, less sharply defined stripes between the latter at the base from costa to submedian rein, where they unite in a loop, the inner stripe being straight and the outer obtusely elbowed; ocelli slightly larger than on the primaries, but similar in character, followed by a nebulous sinuated streak : submarginal line steel-bluish,

Proc. Zoot. Soc.-1895, No. XVII. 
diffused internally but defined externally by a whitish irregularly undulated stripe ; fringes with whitish basal and dark brown central lines; palpi below whitish. Expanse of wings 73-75 millim.

Dry-secison form 9 . Smaller; the angle of primaries less produced below apex; the secondaries with slightly larger and brighter ocelli; a small ocellus indicated on the first median interspace of the primaries: wings below olive-brown, the bands across the primaries lilac, but the apical patch whiter; three sharply defined ocelli coloured as on the upper surface--one small, on upper radial interspace, a second large on lower median interspace, and the third very small, below the second: secondaries with all the whitish markings ill-defined, but both ocelli clearly defined. Expanse of wings 66 millim.

Fwambo.

Four typical specimens and two females of the supposed dryseason form were obtained. It is, without question, by far the most beautiful Junonia hitherto discovered.

Whilst deprecating the positive way in which Lepidopterists have, of late years, decided (without breeding in most instances) respecting the seasonal forms of Butterflies, I do not for a moment pretend to say that their conclusions are unlikely, in most instances, to prove correct. In the present case the two forms of female, though very different in aspect, are so evidently only modifications of the same species that it is but reasonable to conjecture that the smaller form with prominent ocelli is that of the dry-season.

26. Junonta nachtigalir.

Precis nachtigalii, Dewitz, Nova Acta Akad. Naturf. Halle, 1879, p. 194, pl. i. fig. 16 .

Fwambo.

One example of this rare species. Is it the dry-season form of $J$. artaria?

27. Junonia sesamus.

Precis sesamus, Trimen, South Afr. Butt. i. p. 231, pl. iv. fig. 3 (1887).

Zomba.

28. Junonia actia.

Precis actia, Distant, P. Z. S. 1830 , p. 185, pl. xix. fig. 7 .

One male, Zomba.

29. Junonia ARCHESIA.

Papilio archesia, Cramer, Pap. Exot. iii. pl. ecxix. figs. D, E (1782).

ㅇ, Zomba; of ơ, Fwambo.

The whole of the specimens are very dark, larger than usual, and with the red ocellated belt, narrower and slightly darker than in the majority of specimens; the under-surface colouring varies individually to an enormous extent, two examples exactly represent 
the Precis staudingeri of Dewit\%, which is thus seen to be only one of the sports of $J$. archesia.

30. Junonia Chapunga.

Junonia chapunga, Hewitson, Exot. Butt. iii. Jun. pl. i. figs. 2, 3 (1864).

, Zumba.

The pale ocelloid band strongly developed, nearly approaching some specimens of $J$. pelasgis.

\section{Junonia cuama.}

Junonia cuama, Hewitson, Exot. Butt. iii. Jun. pl. i. figs. 4, 5 (1864).

One damaged male, Zomba.

\section{Junonia natalica.}

Precis natalica, Felder, Wien. ent. Monatschr. iv. p. 106 (1860).

One specimen, Zomba.

33. JuNoNia Böopis.

Junonia böopis, Trimen, Trans. Ent. Soc. London, 1879, p. 331. Zomba.

\section{Junonia olelia.}

Papilio clelia, Cramer, Pap. Exot. i. pl. xxi. figs. E, F (1779).

Zomba.

A specimen with narrow white fascia beyond the cell as in J. epiclelia.

\section{Prrameis cardui.}

Papilio cardui, Linneus, Faun. Suec. p. 276. no. 1054 (1761). o, Zomba.

\section{Metacrenis, sp. n.}

Harma (part), Hopffer in Peters's Reise n. Mossambique, v. p. 391. (Type, H. concordia, Hopff.)

$H$. concorclia and its allies have hitherto been regarded as belonging to the genus Crenis; to which, however, they bear but a slight resemblance: their more rounded primaries, pattern, and robust habit are far more characteristic of Argynnis or Atella; but their nearest allies seem to be the species of the genera Hamanumida and Diestogyna, from which, however, the stouter and more erect palpi of the type species would at once separate it if the very dissimilar character of these organs in the allied $M$. rosa did not demonstrate the unreliability of such a distinction. It may, however, be differentiated from Hamanumida as follows:Secondaries comparatively smaller and less produced at anal angle: discoidal cell of primaries shorter, upper discocellular not oblique, inarched; second and third median branches emitted nearer 
together, but with slight variations in the different species; lower discocellular of secondaries better defined. All other characters are inconstant, such as the relative position and length of furca of the subcostal branches of the primaries, the form of the præcostal veinlet of the secondaries, the stoutness of the antennæ, the length and uprightness of the palpi, and the robustness of the thorax; they serve only to distinguish the species.

From Crenis, apart from its totally different outline, broader wings, and utterly dissimilar style of coloration, Metacrenis differs in the longer and cylindrical club to the antennæ, the less strongly inarched discocellulars of the primaries, and the broader and less produced discoidal cell of secondaries. The position of the præcostal veinlet differs greatly in $M$. crawshayi and $M$. rosa-being emitted as in Hamanumida in the former, and as in Crenis natalensis in the latter: in fact, if all the structural characters were to be regarded as of generic value, these two evidently allied species would have to be widely sundered, the first being placed nearer to Hamanumida, the last to Crenis.

\section{Metacrenis crawshayi.}

o. Crenis crawshayi, Butler, P.Z. S. 1893, p. 654, pl. lx. fig. 5.

․ Approaches Hopffer's figure of his M. concordia (Peters's Reise, Zool. v. p. 391, pl. 22. figs. 3, 4, 1862), but the groundcolour above is bright rosy-lavender, with all the black spots much more elongated; the primaries show two little diffused white dashes instead of the oblique yellow bar of $M$. concordic and all the other yellow shades are wanting, but the nervures between the discal and submarginal series of spots have rufous-brownish borders and the spots themselves are connected by blue-grey streaks: below, the colouring is much brighter than in Hopffer's figure, the black spots are elongated; the first four discal spots of the primaries are connected by blue longitudinal streaks with the submarginal spots; there is no continuous blue border on any of the wings, but only small marginal blue spots as in my figure of the male. Expanse of wings 69 millim.

One female, Fwambo.

Hopffer's figures of $M$. concordia, if intended to represent this species, are so bad that it is no marvel that (with the book on my table) a cursory glance at the plate failed to save me from committing what my friend Trimen assures me is a grievous blunder. In the first place, Hopffer described his species as a Harma and in Kirby's 'Catalogue of Diurnal Lepidoptera' it remains in that genus under its emended title; so that, in looking up the known species of Crenis, I naturally did not have my attention particularly called to it. When Mr. Trimen, with his wide knowledge of African Butterfies, assured me that my species was a synonym of Hopffer's, I again looked at the figure and concluded that he was correct; but, with the female of $M$. crawshayi before me, I feel certain, when we see $M$. concordia, that we [12] 
shall discover the illustration to be correct, and the butterfly differing from mine, as above noted ${ }^{1}$; that is to say, in some respects, more nearly related to $M$. rosa, which has the rounded black spots, disconnected blue spots, but continuous blue border of $M$. concordic. It is also most probable that the antennæ and palpi, as well as neuration, will be found intermediate between the two.

37. Hamanumida dedalus.

Papilio dadalus, Fabricius, Syst. Ent. p. 482 . n. 174 (1775).

Zomba.

\section{Pseddargynnis duodecimpunctata.}

Iaera duodecimpunctata, Snellen, Tijd. voor Ent. 2nd ser. part 7, pl. 1. figs. 1, 2 (1872).

ㅇ, Zomba.

39. Atella columbina.

Fapilio columbina, Cramer, Pap. Exot. iii. pl. cexxxviii. figs. A, B, iv. pl. cecxxxvii. figs. D, E (1782).

Zomba.

40. Neptis agatha.

Papilio agatha, Cramer, Pap. Exot. iv. pl. cecxxviii. figs. A, B (1782).

\section{Zomba.}

\section{Acrea cabira.}

Acroea cabira, Hopffer, Ber. Verh. Akad. Berlin, 1855, p. 640 ; Peters's Reise n. Mossamb. p. 378, pl. 23. figs. 14, 15 (1862).

Zomba.

42. Acrea eXCelsion. fig. 3.

o. Acroea excelsior, E. M. Sharpe, P. Z. S. 1891, p. 192, pl. xvii,

o 오, Fwambo.

43. Acrea ventura.

Acroea ventura, Hewitson, Ent. Mu. Mag. xiv. p. 51 (1877). o o , Fwambo.

44. ACR EA ACRITA, var.

Acroce acrita, Hewitson, Exot. Butt. iii. Acr. pl. 3. fig. 18 (1865).

o, Fwambo.

A most interesting specimen, exactly halfway between typical

1 Hopffer says, "Mit einer graublauen Randeinfassung," and, later on, "eine Reihe schwarzer, rundlicher Fleckchen": his locality is Querimba, Mozambique. 
A. acrita and A. pudorina, Staud.: the latter therefore can only be regarded as an imperfectly isolated race of $A$. acrita.

45. ACr $A$ a, sp. inc.

A somewhat melanistic female specimen, having the primaries very like $A$. acrita on both surfaces; but the pattern and coloration of the under surface of the secondaries curiously like $A$. anacreon, with the central rosy band well developed. It would be rash to describe it on this single example, without carefully studying the whole of the species, as it may prove to be an aberrant example of some described species; but, so far, I have failed to identify it. At first I supposed it to be the female of M. Oberthür's $A$. chcoribula, but a careful comparison with the male of that species proves clearly that it is distinct.

Fwambo.

\section{Acrea natalica.}

Acrca natalica, Boisduval, Voy. de Deleg. p. 590 (1847). ơ, Zomba.

\section{ACRAA ARECA.}

Acrcea areca, Mabille, Bull. Soc. Ent. France, 1888, p. clxix; Nov. Lep. p. 100, pl. xiv. fig. 5 (1893).

ơ ơ, Zomba.

\section{Alena aurantiaca, sp. n. (Plate XV. fig. 4.)}

Bright orange above; the cell of primaries black, leaving a triangular subbasal spot and a quadrate subterminal spot of orange; costal border black, with a fine basal orange streak; base, nervures, one or two spots near the base below origin of first median branch and internal border black; external border rather more broadly black, widest at apex, its inner edge sinuated between the nervures; base of the secondaries occupied by a broad irregular black blotch; a black spot on upper discocellular; veins partly black, outer border broadly black : body black; collar tufted at the sides with orange; abdomen orange at the sides. Under surface with the black slightly more restricted than above, the costa of primanes streaked with ochreous, the outer border interrupted by two rows of cream-coloured spots, the inver row irregular, abbreviated, consisting of five oval spots, the outer regular, of seven : secondaries - the basal black patch interrupted by two rows of creamy spots, the inner consisting of four, the outer of two spots; external border enclosing two series of eight creamy-white spots : body black, legs and sides of abdomen orange. Expanse of wings 34 millim.

Two examples (one much damaged), Fwambo.

In the pattern of the upper surface this pretty little species is nearest to $A$. amazoula, but the under surface more nearly approaches $A$. interposita. 
49. Axiocerces amanga.

Zeritis amanga, Westwood, in Oates's 'Matabele-Land,' p. 351 (1881).

ס, Fwambo.

50. Mylothris agathina.

Papilio agathina, Cramer, Pap. Exot. iii. pl. cexxxvii. figs. D, E (1782).

Two females, Zomba.

\section{Terias chalcomieta.}

Terias chalcomioeta, Butler, Ann. \& Mag. Nat. Hist. ser. 5, vol. iii. p. 190 (1879).

Two males, Zomba.

52. Teracolus epigone.

Teracolus epigone, Felder, Reise der Nov. Lep. ii. p. 186.

o, Zomba.

53. Catopsilita pyrene.

Colias pyrene, Swainson, Zool. Ill. i. pl. 51 (1820-21). ơ, Zomba.

54. Berenois mesentina.

Papilio mesentina, Cramer, Pap. Exot. iii. pl. cclxx. figs. A, B (1782).

Two males of the var. lordaca, Zomba.

55. Papilio corinneus.

Papilio corinneus, Bertoloni, Mem. Acc. Bologna, 1849, p. 9, pl. 1. figs. 1-4.

Zomba.

56. Papilio nivinox. (Plate XVI. fig. 4.)

Papilio nivinox, Butler, P.Z. S. 1893, p. 667.

Two males, Fwambo.

This species differs from the allied P. taboranus of M. Oberthür in its superior size; the larger white spots on the subapical area of the primaries; the larger postmedial spots, which form an oblique band; in the white spots of secondaries forming a complete broad belt over the basal two-thirds; in the small discal spots on these wings; in the inner dissal series of under surface consisting of three spots and bounded internally by ochreous clay-colour, in the much larger spots of the outer series; in the confluence of the crimson and yellow on the internal area and the darker submarginal band. 
57. Papilio ophidicephalus.

Papilio ophidicephalus, Oberthür, Études, iii. p. 13 (1878).

q, Zomba.

\section{Tagtades Flesus.}

Hesperia flesus, Fabricius, Spec. Ins. ii. p. 135 (1781).

3, Zomba.

One curious example, in which the hyaline spots on the primaries have either disappeared or been greatly reduced in size.

\section{SaPea trimeni, sp. n. (Plate XV. fig. 5.)}

Abantis zambezina, Trimen (not Westwood), Smith, Afr. Butt. iii. p. 344 , footnote.

Neither the figure nor the description of Westwood's insect correspond with this species, nor is there the slightest reason for Mr. Trimen's supposition that the sides of the abdomen had " probably become discoloured." The following comparison will, I think, show that this view of the case will not account for the differences between the two types:-

Oxynetra zambesiaca, Westwood (not Abantis zambezina).

"The fore wings are chalybeous black.

"The head and body are black, the head with a large white frontal spot, and two small ones between the eyes. The tippets of the collar or prothorax are clothed with scarlet hairs, the tegulæ or wing-scales, together with a pair of dots in front of them, and a second pair behind them at the sides of the disc, as well as the narrow hind margin of the scutellum, white: the latter is followed by a curved band of scarlet, the extremity of the abdomen being of the same colour: the four middle segments of the abdomen are luteous, with a narrow dark longitudinal line down the centre."

Sapa trimeni, Butler (Abantis zambezina, Trimen).

The fore wings are peacock-green, black in the centre; the hyaline spots rather smaller than in Westwood's species, and there is usually a small extra one on interno-median area.

The hind wings have the external area almost wholly metallic Prussian blue (not chalybeous black).

The palpi are almost wholly snow-white, like the frontal patch; there is a central transverse white line on the vertex, as well as the two dots at the base of the antennæ; the pterygodes are purplish black at base, with a large patch of white before the terminal fringe, which is dull black; there is also a double white spot at the base of the front wings.

As with Westwood's species there are two convergent tufts of carmine hairs, forming what he calls " a curved band of scarlet" at the back of the thorax, and the abdomen terminates in a tuft of the same colour, but here the resemblance ceases: the upper [16] 
surface is blue-black, with a broad quadrate snow-white patch occupying three (not four) segments on each side and separated by a broad black dorsal stripe; looking at the insect in protile this patch is seen to be united by a stripe of white to a narrower white patch on the basal segment; the venter, again, is snow-white down the centre, but purplish black at the sides; the front and middle coxal joints are clothed with carmine hair and the sides of the pectus with delicate long white hair; the tibial and tarsal joints are white.

Three specimens, Fwambo.

It is hardly probable that staining would convert three central and a basal snow-white segments of the abdomen into four central fulvous segments, or peacock-green into chalybeous black; but when it is noted that all the other white markings remain unchanged in Westwood's insect, the chance of change by staining becomes next to impossible. The Zambezi insect is probably nearer to S. paradisea than is S. trimeni: thus the fulvous segments are accounted for.

60. Crclopides midas. (Plate XV. fig. 6.)

Cyclopides midas, Butler, P. Z. S. 1893, p. 671.

o, Fwambo.

61. BaORIS INCONSPICUA.

Hesperia inconspicua, Bertoloni, Mem. Acc. Bol. 1849, p. 15.

Fwambo.

One starved example, with unusually brightly-coloured under surface.

\section{Ceratrichia punctulata, sp. n. (Plate XV. fig. 7.)}

Above with the general aspect of $C$. stellata (Cycl. mineni, Trimen), black-brown : primaries with two superposed white dots in the cell, and a slightly irregular elbowed series of eight slightly larger white spots beyond the cell; fringe greyer than the wings, especially at the tips, and interrupted at its base by a series of elongated whitish spots : secondaries with five indistinct whitish dots in a zigzag series beyond the cell ; fringe as in the primaries: abdomen black, edges of segments white laterally; antennæ with white rings, the club only ringed below; palpi greyish. Primaries below blackish, the costal border and apex yellowish olive-brown, traversed by whitish veins; the white spots arranged as above but larger, the elbowed series having an additional white point between the seventh and eighth spots; fringe blackish, with conspicuous elongated white spots and grey tips: secondaries yellowish olive-brown, with whitish veins; the white spots larger than above and seven additional spots, two bounding the middle third of the subcostal area, a small one in the cell behind the upper discocellular, and the other four in pairs bounding the middle third of interno-median area; an indistinct zigzag whitish submarginal line, also feebly indicated on the primaries ; fringe as 
in primaries: legs brown, paler internally; venter whitish. Expanse of wings 30 millim.

A pair, Fwambo.

I have failed to discover any published description of this species.

63. Hesperia?, sp.?

It is impossible to fix even the generic position of this species with certainty, as it has lost its palpi; but it appears to be allied to "Proteides xychus," Mabille, of which it may possibly be the male; the antennæ are white above.

o, Fwambo.

\section{HETEROCERA.}

\section{XANTHOSPILOPTERYX AFRICANA.}

Eusemia africana, Butler, Ann. \& Mag. Nat. Hist. ser. 4, vol. xv. p. $142(1875)$.

Eusemia meretrix, Westwood in Oates's 'Matabele Land,' p. 355 (1881).

ㅇ, Zomba.

Two somewhat worn specimens were obtained.

65. ANom atotes Nigrivenosus.

ㅇ. Anomoeotes nigrivenosus, Butler, P. Z. S. 1893, p. 676, pl. lx. fig. 10.

o. Smaller than the female, creamy pale straw-yellow, with blackish veins and edges to the wings; thorax blackish brown; abdomen golden yellow, becoming tawny on the margins of the segments; pectus and legs brown, venter pale yellow; clasps ochraceous brown, shining. Expanse of wings 28 millim.

o 9 , Fwambo.

Two males and one female, the latter slightly longer in wing and with blacker thorax than the type; the front of the discoidal cell of the secondaries also projects slightly more prominently forward in this example; but slight variations of neuration may be expected to occur in this group of Moths.

66. Argina leonina (=A. AManda, var., Boisd.).

Deiopeia leonina, Walker, Cat. Lep. Het. xxxi. p. 262 (1864).

ơ, Fwambo.

67. Argina ocellina.

Deiopeia ocellina, Walker, Cat. Lep. Het. ii. p. 571. n. 9 (1854). ơ, Fwambo.

The single example of this form has the ground-colour of the primaries white, thus bearing out the opinion which I have long held-that in Africa there is only one species of this genus, of which the synonymy would be as follows :-

Argina AManda.

Euchelia amanda, Boisduval, Voy. de Deleg. ii. p. 597 (1847).

Deiopeia cingulifera, Walker, Lep. Het. ii. p. 569 (1854).

Deiopeia ocellina, Walker, l. c. p. 571.

[18] 
Deiopeia leonina, Walker, l. c. vol. xxxi. p. 262 (186t).

Driopeia albocincta, Rambur, Cat. Lep. Andal. ii. p. 228, note (1866).

Deiopeia serrata, Mabille, Le Nat. i. (3) p. 5 (1879).

Africa generally and Madagascar.

In Madagascar and the Mascarene Islands the allied Indian species $A$. cribraria also occurs; the latter varies considerably and has received many names. Lomaspilis pantheraria, Felder, referred to Argina by Mr. Kirby, is most probably a Geometrid Moth.

\section{Pseudospiris, gen. nov.}

General aspect of Spiris, but the male with simple antennæ, and the radial vein of the secondaries emitted from the middle of the discocellulars; subcostal vein of primaries 5-branched, the first branch emitted long before the end of the cell, the second at the end, the third, fourth, and fifth emitted from a long footstalk from end of cell, the upper radial is also emitted from the inferior margin of the same footstalk; in the secondaries the subcostal branches are emitted from a short footstalk; the frenum is very long in both sexes; the palpi are short, the antennæ thick and not unlike those of the Agaristidac; a prominent black corneous frontal process. Type, $P$. paidiformis.

\section{Pseudospiris Paidiformis, sp. n. (Plate XV. figs. 8, 9.)}

$\sigma^{*}$. Curiously like Pais gordoni both in pattern and colouring: primaries above pale buff, a black costal line running from the base to the basal fourth, from which point it thickens and leaves a narrow edging of the ground-colour to apex; a $<$-shaped subbasal line, the lower furca of which runs along the submedian vein, a dot near base of discoidal cell, a bisinuated undulated line across basal fourth to submedian vein, two annular markings forming an oblique 8-shaped character, an annular sigmoidal marking over end of cell, an oblique line, slightly zigzagged above the middle, at external third, a series of longitudinal internervular streaks to the outer margin, and the margin itself black; an irregular interrupted ferruginous-red band across the basal area between the two black lines; the inner border, excepting at base, and a band, of the same form as and immediately beyond the zigzagged discal black line, also ferruginous red, but the band edged on both sides with metallic silver scales: secondaries ferruginous red, with the apex, outer margin, and fringe blackish: thorax black, varied with whitish; abdomen ochreous, banded with blackish. Under surface of wings pale tawny ferruginous, with the costal borders yellower; a tapering external vellowish border intersected by black stripes from costa, in the primaries extending to external angle and bounded on the costa by a blackish spot, but in the secondaries terminating at the extremity of the first median branch, bounded internally by a dusky streak, which becomes paler towards its inferior extremity; a blackish bar on the discocellulars : pectus blackish, clothed with ochreous hair; sides of frontal process and palpi white: tibiæ striped longitudinally and tarsi barred with 
white; venter with whity-brown basal segment, otherwise ochraceous barred with black-brown. Expanse of wings 49 millim.

․ Primaries of a clearer yellowish tint than in the male, and with silvery scales sprinkled over the subbasal red markings and within the black annular markings : secondaries ochreous; a black curved bar on the discocellulars; outer border black, enclosing six ochreous spots and suffused, near anal angle, with ferruginous. Under surface ochreous, the external border bounded by a black stripe throughout and divided into elongated spots by black nervures; primaries with three blackish nearly central patches, answering to the annular markings of the upper surface; secondaries with the discocellular bar as above, and two small black spots in the cell: body below black, spotted with cream-colour and ochreous. Expanse of wings 53 millim.

Fwambo.

One male and two females were obtained. The male most nearly resembles Pais gordoni when the wings are open; the female when they are closed, owing to the ochreous colouring of its secondaries.

69. Gnophria (?) furcifasciata, sp.n. (Plate XVI. fig. 5.)

ㅇ. Primaries above silvery cream-white; the costal margin, fringe of outer margin, an irregular stripe before the middle elbowed just above the submedian vein, and a sigmoidal stripe commencing near apex and terminating at outer third of inner margin, with an inner subsigmoidal fork from median vein to outer fifth of costal margin, jet-black: the secondaries clear bright straw-yellow : body ochreous, the abdomen barred with blackish. Primaries below smoky grey, the borders irregularly ochreous, interrupted on the costa towards apex by two transverse bars of the ground-colour, so as to leave a subapical quadrifid ochreous patch: secondaries ochreous or straw-yellow, with a tapering subapical bar from costa: body below ochreous; tarsi and venter barred with black. Expanse of wings 51 millim.

Fwambo.

Of this very striking species we only received one imperfect specimen wanting a head: doubtless it is not, strictly speaking, a Gnophria, but an allied new genus, the lower radial of the primaries being independently emitted from the inferior augle of the cell instead of from the third median branch; but in the secondaries the radial forms a very short furca with the extremity of the third median branch, the footstalk occupying about three-fourths of the distance between the cell and the margin; with only an imperfect female, however, it would be premature to propose a new genus for its reception.

70. Alpendes aqualis, var.

Alpenus aqualis, Walker, Lep. Het. iii. p. 686 (1855).

Fwambo.

Eastern examples differ from the Western type in having the [20] 
annular markings on the primaries filled in with black and partly confluent towards costa ; in all probability a series collected right across Africa from west to east would exhibit every grade from one type to the other: it is also extremely probable that $A$. cequalis will prove to be quite inseparable from $A$. maculosus of Stoll, which only differs in its finer maculation.

71. Pleretes thelwalli.

Hypercompa thelwalli, Druce, P. Z. S. 1882, p. 779, pl. 61. fig. 1. Zomba.

One female was obtained.

72. LECHRIOLEPIS VARIA.

Amydona varia, Walker, Lep. Het. vi. p. 1414 (1855).

Fwambo.

A most brilliantly coloured species when in good condition.

73. Lebeda venosa, sp. n. (Plate XVI. fig. 6.)

Primaries to beyond the middle greyish flesh-colour, beyond which they are darker brownish flesh-colour; the costa and all the veins deep ochreous; two ill-defined whitish stripes, the first transverse, straight, crossing the centre of the paler basal area, the other oblique, bounding the basal area beyond the middle ; an illdefined pale spot in the upper angle of the cell and an irregular discal series of whitish spots or lunules, with greyer external borders; fringe cream-coloured: secondaries brownish fleshcoloured, shading into ochraceous buff towards base and abdominal margin; veins and fringe as on the primaries: thorax pinky ochraceous, deeper at centre of collar and base of pterygodes; sides of collar greyish ; antennæ greyish flesh-coloured, abdomen ochraceous buff. Wings below greyish flesh-coloured, with the veins, margins, and basal hairy clothing ochreous; body below ochreous. Expanse of wings, o 81 millim., o 70 millim.

Fwambo.

I had an idea that I had seen an illustration of this species, but finally discovered that Moeschler's Philotherma jacchus was the insect I was thinking of. The primaries of the latter are very similar, both in general coloration and pattern, to $L$. venosa, but the secondaries are entirely different both in form and coloration.

74. HibRILDES NORAX.

Hibrildes norax, Druce, P. Z. S. 1887, p. 675.

, Fwambo.

One much-worn example was obtained.

75. TaNoropsis FLAVINATa.

Dreata flavinata, Walker, Lep. Het. xxxii. p. 573 (1865).

ㅇ, Fwambo.

A slightly aberrant example, though apparently hardly referable to a distinct species. 
76. ANTher ea emini.

․ Anthercea emini, Butler, P. Z. S. 1888, p. 84.

$\sigma^{*}$. Above very like $A$. dione $\delta^{*}$, but much larger and with considerably larger ocelli, that on the secondaries uniting the two transverse dusky bands as in the female, the outer band, as in that sex, more parallel to the outer margin than in $A$. dione; colouring below similar to that of $A$. clione $q$, but with the whitish areas better detined. Expanse of wings 144 millim.

o, Fwambo.

77. ANTher ea? zaddachil.

Saturnia zaddachii, Dewitz, Mitth. Münch. ent. Ver. iii. p. 34, pl. ii. fig. 6 (1879).

of $q$, Fwambo.

I believe this and the preceding species would be more correctly referred to Buncea.

78. Bunfa nictitans.

Buncea nictitans, Maassen \& Weym. Beitr. z. Schmetterlingskunde, fig. 53.

Fwambo.

One example only. The species is evidently allied to the preceding and to Anthercea belina.

79. Cyligramma latona.

Phalaena (Noctua) latona, Cramer, Pap. Exot. i. p. 20, pl. xiii. fig. B (1779).

Zomba.

80. Calliodes graduescens.

Calliodes glaucescens, Butler, P. Z. S. 1893, p. 680. n. 187.

Two feinales, Fwambo.

\section{DESCRIPTION OF THE PLATES.}

Plate XV.

Fig. 1. Charaxes macclounii on, p. 252.

$2 . \quad$ leoninus $\delta$, p. 253.

3 . " whytei 오, p. 255 .

4. Alcena aurantiaca, p. 262.

5. Sapar trimeni, p. 264.

6. Cyclopides midas, p. 265.

7. Ceratrichia punctulata, p. 265.

8, 9. Pseudospiris paidiformis, p. 267.

\section{Puate XVI.}

Figs. 1, 2. Junonia pavonina ${ }^{\circ}$, p. 257.

Fig. 3. " " dry-season form.

4. Papilio" nivinox,"p. 263.

5. Gnophria furcifasciata, p. 268.

6. Lebeda venosa , p. 269. 


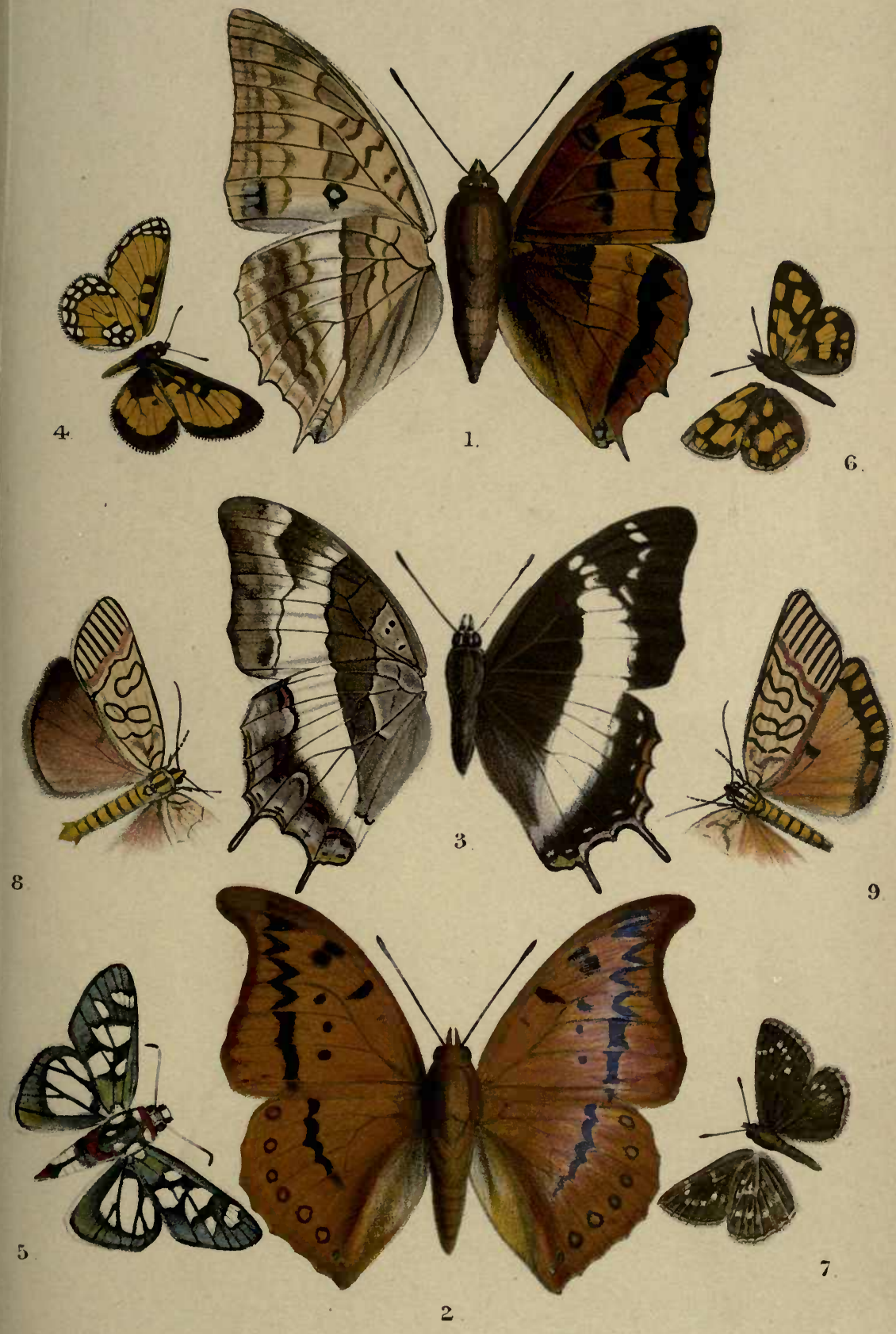



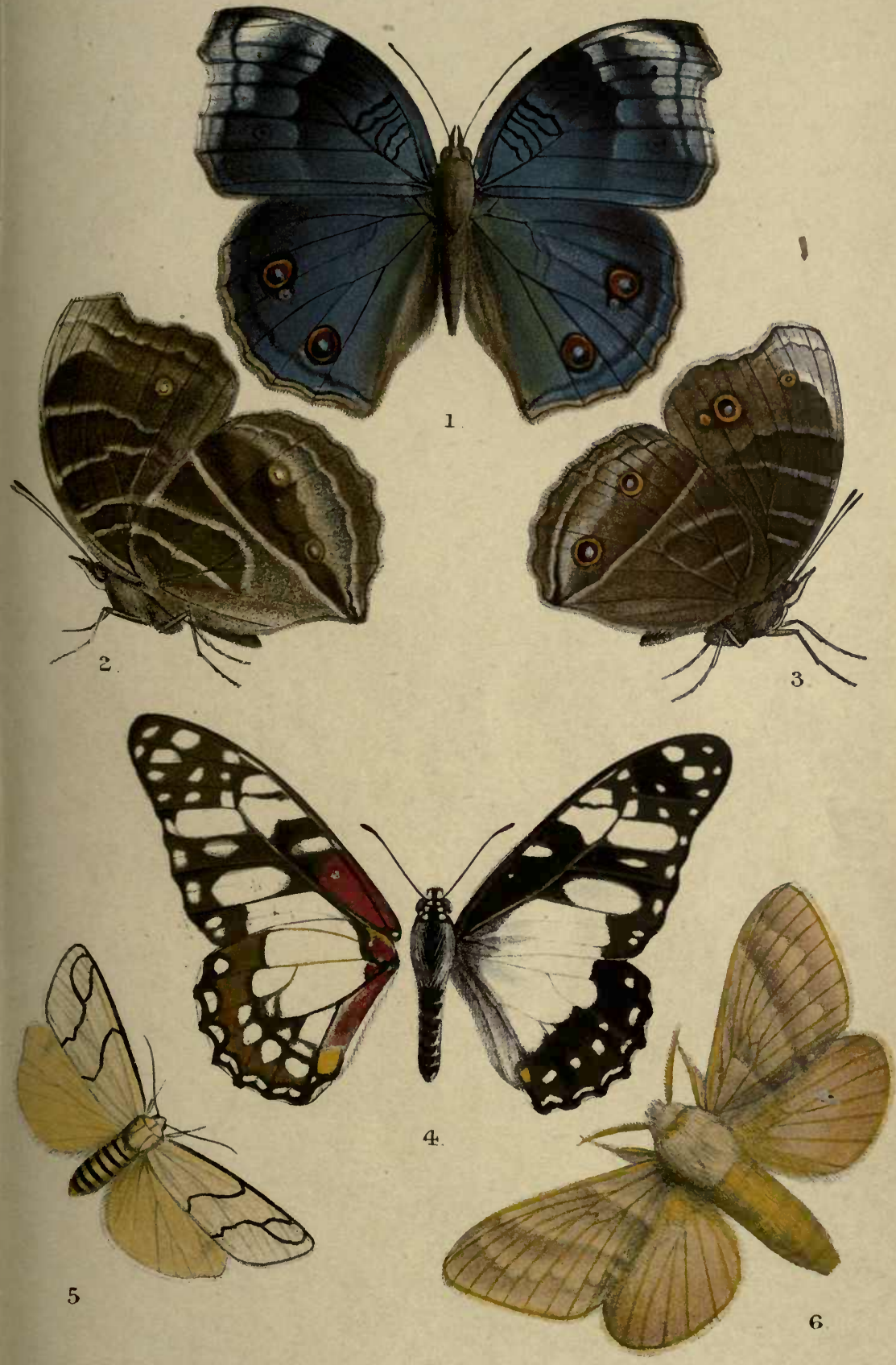


西 

Description of a new Species of Butterfly of the Genus Amauris obtained by $\mathrm{Mr}$. Scott Elliot in East Central Africa. By Arthur G. Butler, Ph.D., F.L.S., \&c.

Two examples of a very distinct species of the A. echeria group were obtained, both males-one taken at Ruwenzori, 5000-6000 feet alt., the other on the way from Salt Lake to Wawamba Co.

\section{Amauris Ellioti, sp. n.}

万. Form of A. echeria, larger: primaries black, slightly brownish towards the base; all the markings deep ochreous, as follows:- a broad oblique spot across the middle of the discoidal cell and a second (slightly larger) before the middle of the first, or lower, median interspace, a small elongated spot above the upper extremity of the discoidal cell, a quadrifid spot beyond the cell, its two upper divisions smallest, the third division largest, a bifid subcostal spot towards apex and two small spots (the upper one larger than the under) obliquely below it; three conspicuous nearly equidistant oval spots, one below each median branch towards outer margin and three nearly marginal points towards the middle of the 
margin ; the general distribution of these markings, therefore, is similar to that of $A$. echeria, but their relative proportions are more nearly as in $A$. lobengula; the quadrifid spot beyond the cell is, however, different in character from that of all the known species: secondaries browner, sericeous towards anal angle, and with the sexual patch somewhat ill-defined; an elbowed ochreous belt occupying the basal two fifths and traversed by the black subcostal vein and part of its first branch; a discal irregular series of eleven large ochreous spots, of which the first, sixth, and eighth are distinctly larger than the others; a nearly marginal series of seven to eight dots in pairs, commencing from the second subcostal vein : body pitchy black-brown, with two white points on the head. Wings below brown, the apical area of the primaries and outer three fifths of the secondaries somewhat olivaceous; all the ochreous markings paler than above, and several additional small spots or dots near to the outer margin in all the wings.

Expanse of wings 80 millim.

Two male examples.

Perhaps the most distinctive characters in this species are the position of the ochreous belt of the secondaries at, instead of a short distance from, the base, the consequent widening of the dark external area, and the great size of the spots of the discal series on these wings, reminding one of Tirumala limniace. 

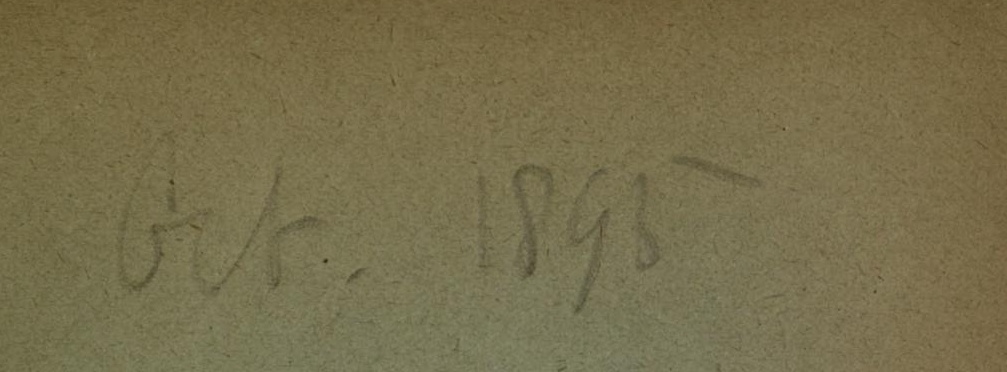

:.

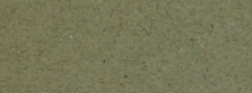

T.

49135

xis

isicis $4 x+4 x^{2}$

$\frac{1}{2}$

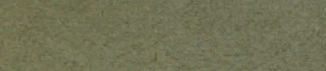

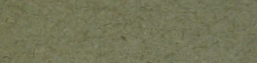

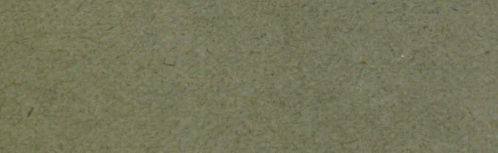

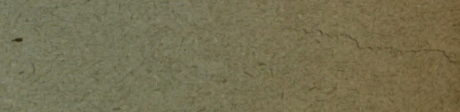
(1. 

XXII. Notes on Seasonal Dimorphism in certain African Butterflies. By Artinur G. Butler, Ph.D., F.L.S., etc.

[Read Oct. 16th, 1895.]

Mr. CeCIL W. Barker's most interesting and instructive paper upon this subject is before me, and I only regret that the impossibility of risking the effect of night air prevented my being present at the meeting in April, when it was read, because I note, in the Proceedings of the Society, that the question was asked by Prof. Meldolin whether Mr. Barker's observations had been supported by breeding experiments. Although this had not been done, our cabinets afford such a mass of evidence in support of his suggestions, that the case may be almost considered as good as proved.

As an example of what is here affirmed I may take one example; that of Teracolus vesta:-

The form T. argillaceus differs from the typical form chiefly in the rosy-ochreous instead of lemon-yellow colouring of the undersurface of the hindwings and apical area of forewings. If such a difference occurred in one type only of the same group, it might fairly be considered to have a specific value; but when we tind that it recurs throughout the group, whether in Asia or Africa, the evidence in favour of its being illustrative of seasonal dimorphism becomes almost conclusive; so much so, that most Lepidopterists will certainly accept it, as having the authority of proof.

The following forms of this group of Teracolus in the Museum series will, in this event, have to be united :-

\section{Astatic Species.}

Summer form

1. Unnamed. 2. Teracolus vestalis, Butl. Teracolus intermissus, Butl. 3. Teracolus puellaris, Butl. Teracolus ochreipennis, Butl.

Winter form

Teracolus protractus, Butl. TRANS. ENT. SOC. LOND. 1895.-PART IV. (DEC.) 


\section{Aprican Species.}

Summer form.

4. Teracolus vesta, Reiche. Teracolus argillaceus, Butl. 5. Teracolus aurigineus,Butl. Teracolus venustus, Butl. 6. Teracolus chrysonome, Klug. Teracolus helvolus, Butl. 7. Teracolus gaudens, Butl. Teracolus arenicoleus, Eutl.

Seasonal dimorphism in butterflies is certainly much commoner than is generally supposed, and when thoroughly understood, will tend to explain away the difficulties arising from a study of intermediate grades between apparently distinct types, which will then be seen to be merely dry and wet-season forms of one and the same species.

As an example, I may mention that in the genus Acræa Dr. Staudinger, some years since, described a species under the name of $\dot{A}$. pudorina, and he observed"Hewitson regards this specimen as a doubtful variety of his Acrita, a beautiful example of which I also possess from Zanzibar. But Acrita has four to five large black spots on the forewings, and notably a broad black apex to the same, wherefore Pudorina can never belong to it." In $1894 \mathrm{Mr}$. Trimen figured a variety, observing that "Both sexes show a good deal of variation as regards the width of the apical fuscous border in the forewings, and in the numbers (seven or eight) and relative sizes of the rounded discal spots in the hindwings," etc., and in the same year I mentioned (P.Z.S., pp. 566-7) :- "There is not the slightest question that this (A. pudorina) is a local representative of $A$. acrita, from which it only differs in the absence of the broad apical black patch on the primaries; in well-marked examples all the spots (on the absence of which Dr. Staudinger relies) are well defined; one specimen even shows an additional spot on the subcostal area, nearer to apex."

In 1895, however, I was forced to modify my opinion as regards the local value of the difference, by the arrival of a collection from Fwambo, B. C. Africa, in which we received an intermediate example "half-way between typical A. acrita and A. pudorina" (See P.Z.S., 1895, p. 261), which led me to adopt a different view respecting the meaning of this apical patch.

Among the species of the group to which $A$. acrita belongs, the apical black patch occurs no less than five 
Seasonal Dimorphism in certain African Butterflies.

times, and is, in each case, regarded as the principal character for distinguishing two otherwise similar species. Comparing the under surfaces, one sees either no difference whatever, or only such as has a purely individual value; whilst, occasionally, individuals come to hand in which the apical black patch of the upper surface varies between the two extreme types, clearly proving it to be valueless as a specific character; A. acrita indeed is only one of those intermediate grades itself, for the black apex is still more largely developed in $A$. chæribula.

These differences in Acrxa I believe to be seasonal ; the examples with the black apical patch being the wetseason forms. Supposing this to be a correct explanation of this curious and certainly inconstant difference, the species will stand as follows :-

Dry-season form.

Wet-season form.

1. Acræa anacreon, Trimen. *Acræa bomba, H. G. Smith. 2. Acræa guillemei, Oberth. Acræa periphanes, Oberth. 3. Acræa doubledayi, Guér. Acræa dircæa, Westw. 4. Acræa stenobæa, Wallgr. Acræa caldarena, Hewits. 5. Acræa pudorina, Staud. Acræa chæribula, Oberth.

With regard to the above associations, it must be borne in mind that a species which, in a variable climate, is dimorphic, ceases to be so in a uniform climate, and thus it does not follow, because a species does not vary in one part of Africa, that it therefore shows equal constancy in anotber part: indeed, we now know that some of the Southern species which appear to breed from generation to generation true to type, break up into two widely different types in Central Africa. Then, again, in a climate neither unusually dry nor wet, an intermediate type may prevail, to the exclusion of the extremes. Hitherto we have not received typical $A$. pudorina from Nyasa-land, but we have a form so near to it, that no Lepidopterist would have the temerity to describe it as a distinct species ; secondly, we have typical $A$. acrita ; and, lastly, A. chrribula, $\uparrow$ from Zomba.

Climatic modifications and seasonal forms result

- I cannot distinguish $A$. induna as a species, from this.

+ I consider this the same as A. ambigua, Trimen. 


\section{Dr. A. G. Butler on Seasonal Dimorphism.}

practically from the same cause, and in some cases it will be very hard to draw the line between them: a uniformly moist locality may produce only a wet-season form, and a dry locality the converse; yet one could hardly speak of Acræa pseudegina as a seasonal form of A. natalica, but merely as a western development of that species (an intermediate form completely linking the two extremes occurs in Angola).

Whether the colour variations of Acræa johnstoni and other members of the A. esebria group are seasonal seems doubtful; indeed, from the evidence before me, I should say-certainly not; for we have extreme forms, collected within three days, that is to say, with only one day's interval between, and, moreover, both forms are in admirable condition. The species of the $A$. esebria group are therefore probably simply inconstant, no satisfactory reason for such inconstancy being at present known, or even guessed at.

The above observations will, I hope, help to impress upon collectors the importance of noting not only dates of capture of every specimen which they obtain, but also the altitude and nature of climate, so that Lepidopterists may have some definite data to work from in deciding these interesting questions touching the climatic relationships or seasonal dimorphism of the insects which come into their hands. 
and

.

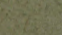

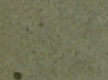

.

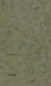

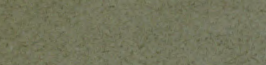

r.

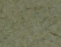

$x^{3}+x^{2}$

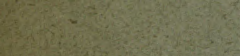

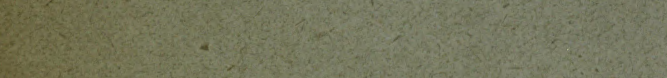

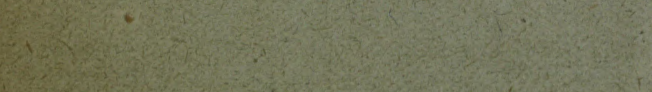

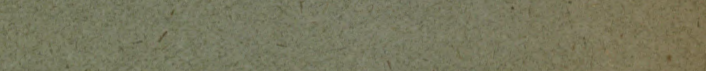

W.

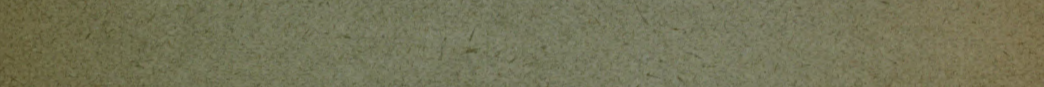

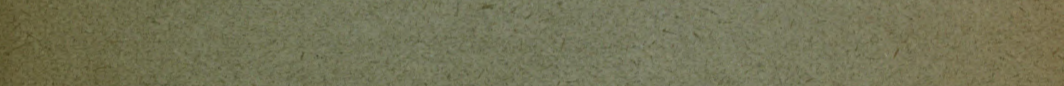
13. Q4.

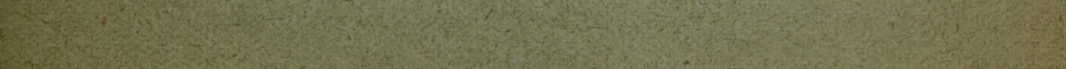

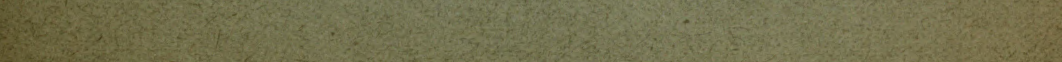

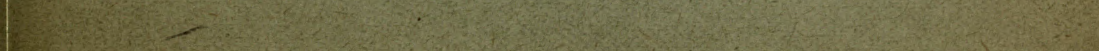



Nov. 1895 



\section{On a small Collection of Butterflies made by Consul Alfred}

\section{Sharpe at Zomba, British Central Africa. By Artruur G. Butler, Ph.D., F.L.S., F.Z.S.}

The present collection, brought home by Consul Alfred Sharpe on his recent return from Nyasaland, was forwarded to me by our Secretary, with permission to select such specimens as were required for the Museum series. Among the specimens is an example of a fine new species of Papilio, which I here describe.

The following is a list of the species of which examples were obtained: it will be seen that, as usual from this locality, the genus Charaxes is well represented:-

1. Amauris whytei, Butler.

2. " dominicanus, Trimen.

3. Limnas chrysippus, Linn.

4. Eurytela dryope, Cramer.

5. Charaxes brutus, C'ramer.

6. " druceanus, Butler.

7. " pollux 9 , Cramer.

8. " saturnus, Butler.

9. " " guderiana, Dewitz.

10. " " ethalion, Boisd.

11. " whytei, Butler.

1\%. " lasti, Grose-Smith.

15. " leoninus, Butler.

14. " cithæron, Felder.

15. " bohemani, Felder.

16. " eupale, Drury.

17. Euralia wahlbergi Wallengr.

18. " mima, Trimen.

19. Junonia tugela $\delta^{*}$, Trimen.

20. " cum,ma, Hewits.

21. " " clelia, Cramer.

22. " " boopis, Trimen.

2:3. " " sesamus, Trimen.

24. " $"$ artaxia, Hewits.

25. Pyrameis cardui, Linn.

26. Protogoniomorpha anacardii, Linn.

27. Euphædra neophron, Hopff.

28. Pseudargynnis duodecimpunctata, Snellen.
29. Crenis boisduvalii, Wullengr.

30. Neptis agatha, Cramer.

31. Atella columbina, Cramer.

3:. Argynnis smaragdifera $q$, Butl.

33. Acrea cabira, var. apecia ı, Oberth.

31. " oncra ㅇ, Hoptf.

35. " buxtoni, Butler.

36. " " sganzini, Boisd.

37. " natalica, Boisd.

38. " acrita, Hewits.

39. " areca, Mabille.

40. " guillemei, Uberth.

41. Mylothris agathina, Cramer.

42. Terıs regularis, Butler.

43. Catopsilia florella, $\mathrm{Fabr}$.

44. Papilio policenes, Cramer.

45. " corinneus, Bertol.

46. " demoleus, Linn.

47. " " bromius, var. broutes, Godman.

48. " erinus, Gray.

49. $"$ p.lodurus, sp. $n$.

50. Tagiades flesus, $\mathrm{Fabr}$.

51. Proteides erinnys, Trimen.

52. Nephele funebris, $\mathrm{Fabr}$.

53. Pleretes thelwalli, Druce.

54. Patula walkeri, Butler.

\section{Papilio petadurts, sp. $\mathrm{n}$.}

\%. Allied to P. horribilis. Wings black, brownish at base, with golden-brown tails; markings of primaries cream-coluured traversed by black veins, similar in disposition to those of P. horribiiis, but the oblique bar beyond the cell and discal belt much broader, more uniform in width, the discal belt also emitting a triangular spur above the third median branch: secondaries with 
the transverse belt half as wide again, extending well beyond the end of the cell; the discal spots also larger; a broad $\boldsymbol{\Lambda}$-shaped orange-ochreous narking above the anal angle and a paler ochreous marginal lunule below it; other marginal lunules between the veins lemon-yellow; sides of body.argillaceous: under surface of wings nearly as in P. horribilis, but the pale areas more coppercoloured; the creamy bar and belt of primaries nearly as above, the tapering band across the secondaries slightly different in outline and more prominent, two well-defined triangular whitish spots at base of second median and upper radial interspaces: pectus and legs as in P. horribilis. Expanse of wings 110 millim.

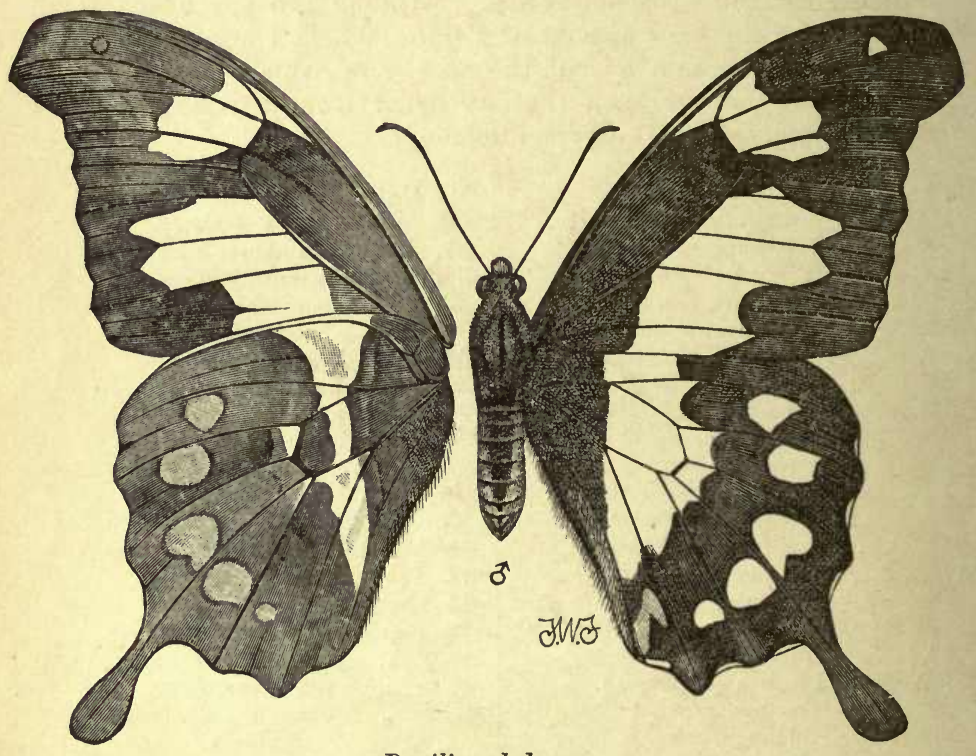

Papilio pelodurus.

One male specimen only was obtained, but Mr. Aurivillius, whose wide experience in African Lepidoptera gives great weight to his opinion, agrees with me that it is a representative of an entirely new and very beautiful species. I should have liked to dedicate this Papilio to its discoverer, but I am afraid that the name has been already employed.

[From the Proceedings of the Zoological Society of London, November 19, 1895.] 
Sin 

Nor. 1895 

Descriptions of new Species of Planema in the Collection of the British Museum. By A. G. Butler, Ph.D. \&c.

WHILST recently rearranging the Museum collection of Acraince of the Old World, and incorporating the fine series presented by Messrs. Godman and Salvin, I came upon the following undescribed species of Planema:-

\section{Planema Salvini, sp. $\mathrm{n}$.}

Nearest to $P$. camerunica, the male with the discoidal area of primaries, the area below the cell, and the band crossing the centre of the wing golden orange instead of tawny; the transverse band itself more regular, especially along its outer margin; secondaries with the basal spots arranged as in $P$. formosa and followed by a diffused whitish band, more distinctly white on the under surface: the female chiefly differing from that sex of $P$. camerunica in the much less irregular inner edging of the white belt on the primaries (which is less distinctly continued below the first median branch) and its less prominent external angle, so that the deep-brown apical area is broader in this species: the secondaries much more nearly resemble those of the female of $P$. formosa, but the white belt across them is broader and more diffused. Expanse of wings, ot 75 millim., $q 93$ millim.

Fernando Po and Cameroons (from the Godman \& Salvin Collection).

The natural position of this species is undoubtedly between $P$. formosa and $P$. camerunica.

\section{Planema Godmani, sp. n.}

Allied to P. camerunica and P.alcinoe; the male has almost the same pattern on the primaries as the latter species, excepting that the inner blackish edging of the central band is usually almost wholly lost, so that these wings become 
divided into two equal parts, the apical lialf smoky blackish. the basal half bright orange-tawny; the blackish inner edging, however, is always faintly, and sometimes strongly, represented : the secondaries are quite distinct from those of $P$. alcinoe, the basal spots being small and more restricted upon a reddish-tawny ground; beyond them is a diffused band (traversed by the dark veins and internervular streaks), its centre golden orange, its extremities whitish; the external area smoky brown, paler internally, sometimes becoming almost white as it merges into the central band. The female has primaries like those of $P$. camerunica + , but the basal spots of the secondaries are more restricted and their outer limit forms a straighter line than in $P$. camerunica, whilst the brown basal patch on which these spots are usually placed is infringed upon by the broader white central belt; the latter is more regular and of more uniform width throughout. Expanse of wings, of 69-78 millim., o 88 millim.

Sierra Leone (B.M. and Salvin \& Godman Colls.).

We had long had a pair of this species in the Museum collection as $P$. alcinoe of Felder; the latter, however, is quite distinct, both sexes showing a well-defined and rather narrow dusky border to the secondaries. We have a pair from Accra.

\section{Planema indentata, sp. $\mathrm{n}$.}

The male has smoky-brown primaries, similar to other species of the $P$. alcinoe group, but the belt across the wing, excepting that it is broader and golden orange, resembles that on the primaries of $P$. elongata $\delta$; the secondaries are like those of $P$. macaria, but much paler, the central area being broadly pale yellowish, almost inclining to whity brown, of course interrupted by the usual dusky veins and streaks; the female has the primaries marked somewhat as in P.camerunica $O$, but the broad white band has its inner edge nearly straight, two small notches alone indicating the angular excavations which characterize this band in P. camerunica: the secondaries are quite distinct, pale sandy yellow, the base narrowly brown, so that all the outer black spots are thrown into strong relief; the external border almost as narrow as in $P$. alcinoe $q$, but emitting much more prominent internervular blackish streaks to the middle of the wing. Expanse of wings, of 78 millim., o 100 millim.

One pair, Cameroons (Godman \& Salvin Coll.).

The female was taken by Dr. Preuss at Barombi.

Quite recently Dr. Karsch has described a female Planema from Uganda under the name of $P$. albicolor, which he says 
corresponds with the same sex of $P$. consanguinea so closely that the only difference of marking which he is able to point out is the slightly smaller size of the basal spots of the hind wings. "In the of from Uganda, however, all the yellow and red-brown of the wings and body of Planema consanguinea are entirely white," a most singular statement! He means to say that the yellow and red-brown areas of $P$. consanguinea are replaced by white in the female from Uganda. I must express my positive conviction that this $P$. albicolor is nothing whatever but the rare albino form which constantly recurs in many species of $A$ croca, and which may also exist in some species of Planema. It is true, indeed, that the white forms of many species of Acroea have been described as distinct, but they always occur with the typical forms as either seasonal developments or simple sports; the following may be cited:-

Tawny form.

1. Acræa Johnstoni, 0 .

2. " alciope, ㅇ.

3. " esebria, ơ 오.

4. " metaprotea, 0 오.

5. " apecida, ơ 오.

6. " vinidia, 웅.

7. " Sganzini, ơ 9 .

8. " stenobæa, of 9 .

9. " caldarena, ơ 9 .

10. " acara, ơ 0 .

11. " marmorata, of 9 .

12. " percussa, 0 .
Yellow or white form.

Acræa flavescens, ot.

" carmentis, 우.

$"$ protea, of 9 .

" Monteironis, ơ $q$.

" Cabira, of ㅇ.

" tenella, ơ 0 .

" lycia, ơ 9 .

" cæcilia, o" ㅇ․ $^{\prime}$.

" neluska, $q$ only.

" pseudolycia, of only.

" turna, ơ 9 .

" igati, 0 .

Several other species have a white as well as a tawny form of female; so that to found a new species upon a female alone, which (to all intents and purposes) differs in nothing but its white colouring from its nearest ally, is in the highest degree venturesome. Differences of pattern are alone to be relied upon in the Acrceince, the ground-colour varies enormously, the width of the black apical patch varies seasonally, the number of spots on the under surface varies a good deal in certain species, but the position of the spots, the outlines of the bands, and width of the hind wing border do not appear to be variable in Planema, or very slightly so; but in Acrcea the width of the outer border varies considerably.

* This is rather a pale than a white form, and is perhaps a climatic variety. 





(1) 


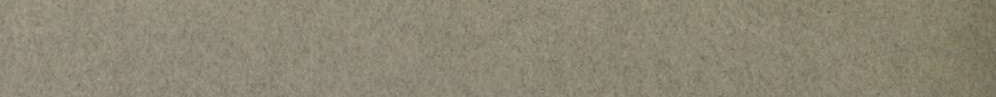

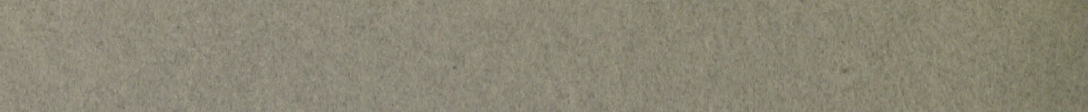

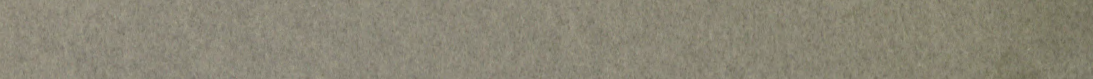
S. (6) A W. S.

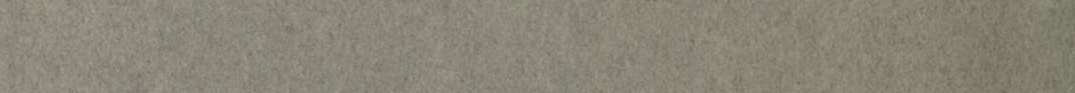

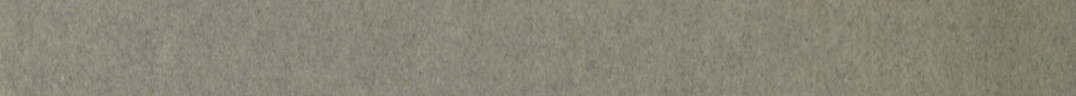
(x)

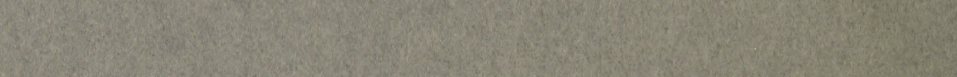
S.

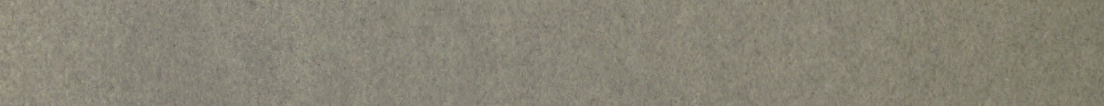

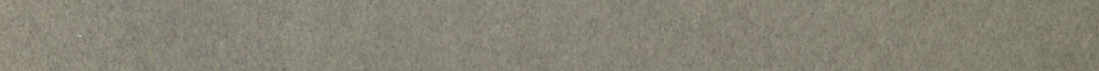

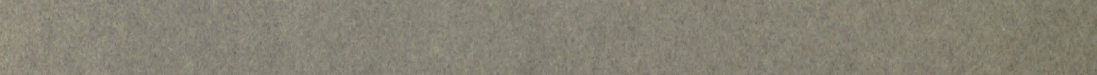

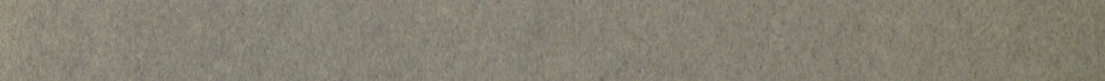

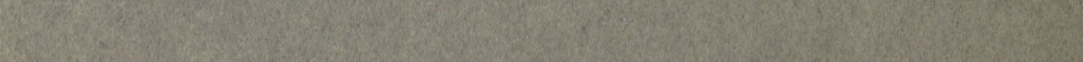

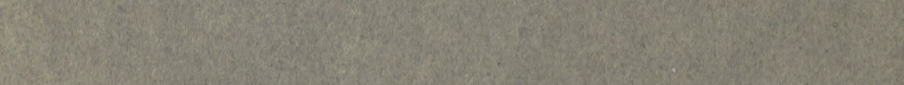

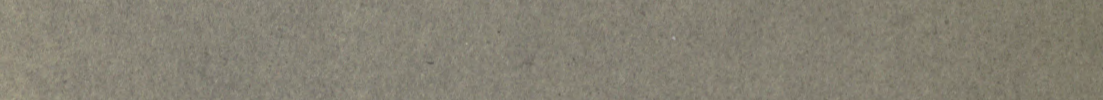

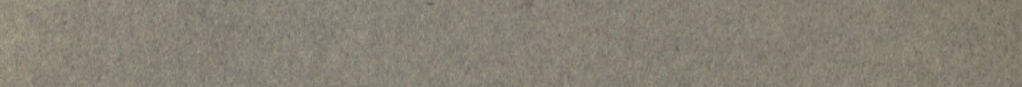
3.5.

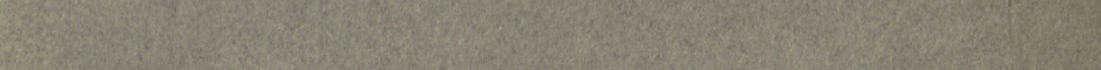

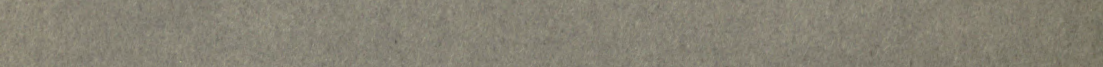

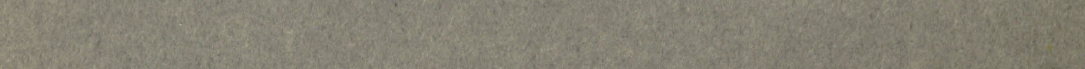

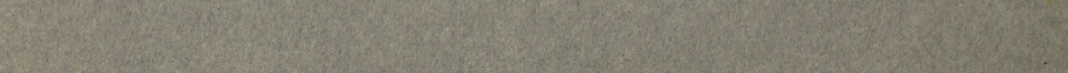

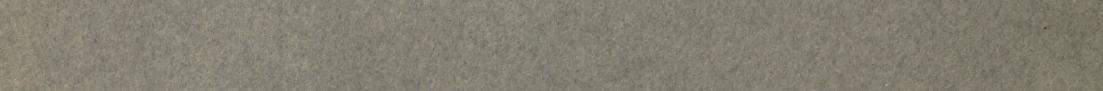

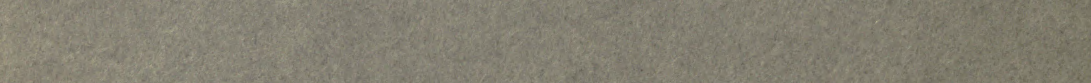

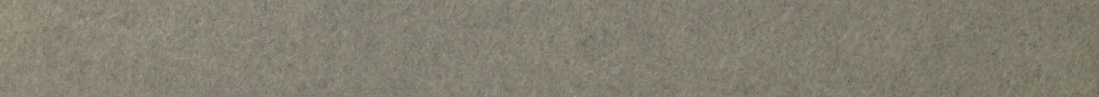

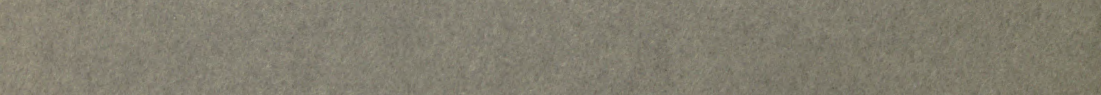

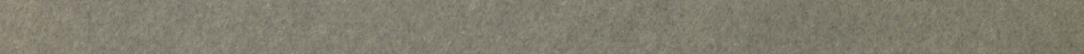
B.

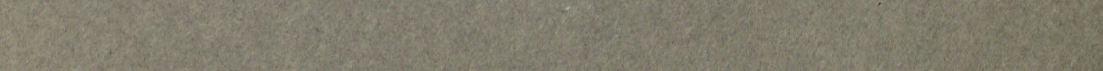

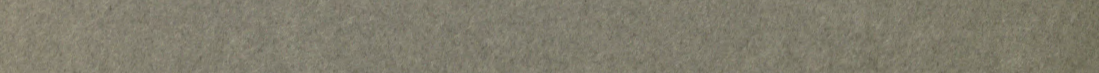

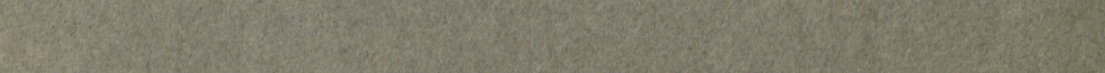

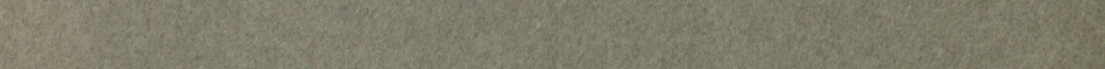
13.

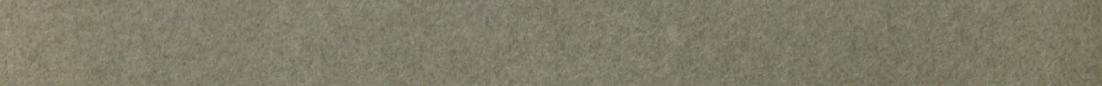

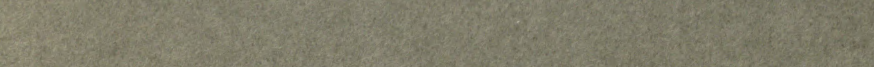

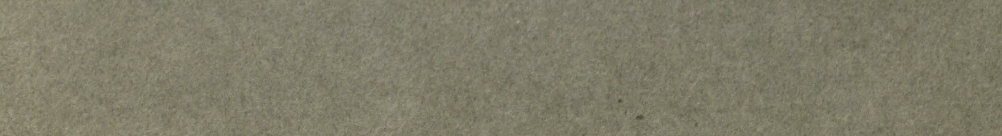




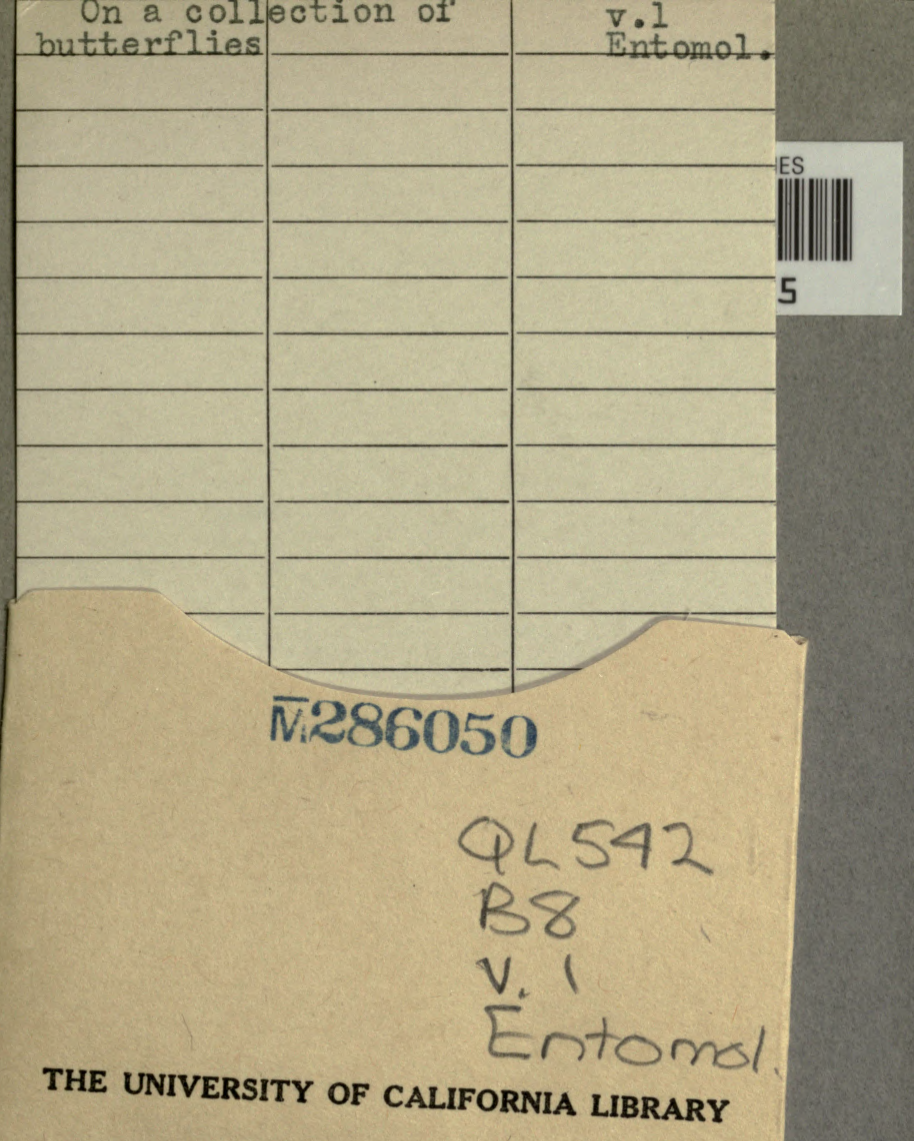


